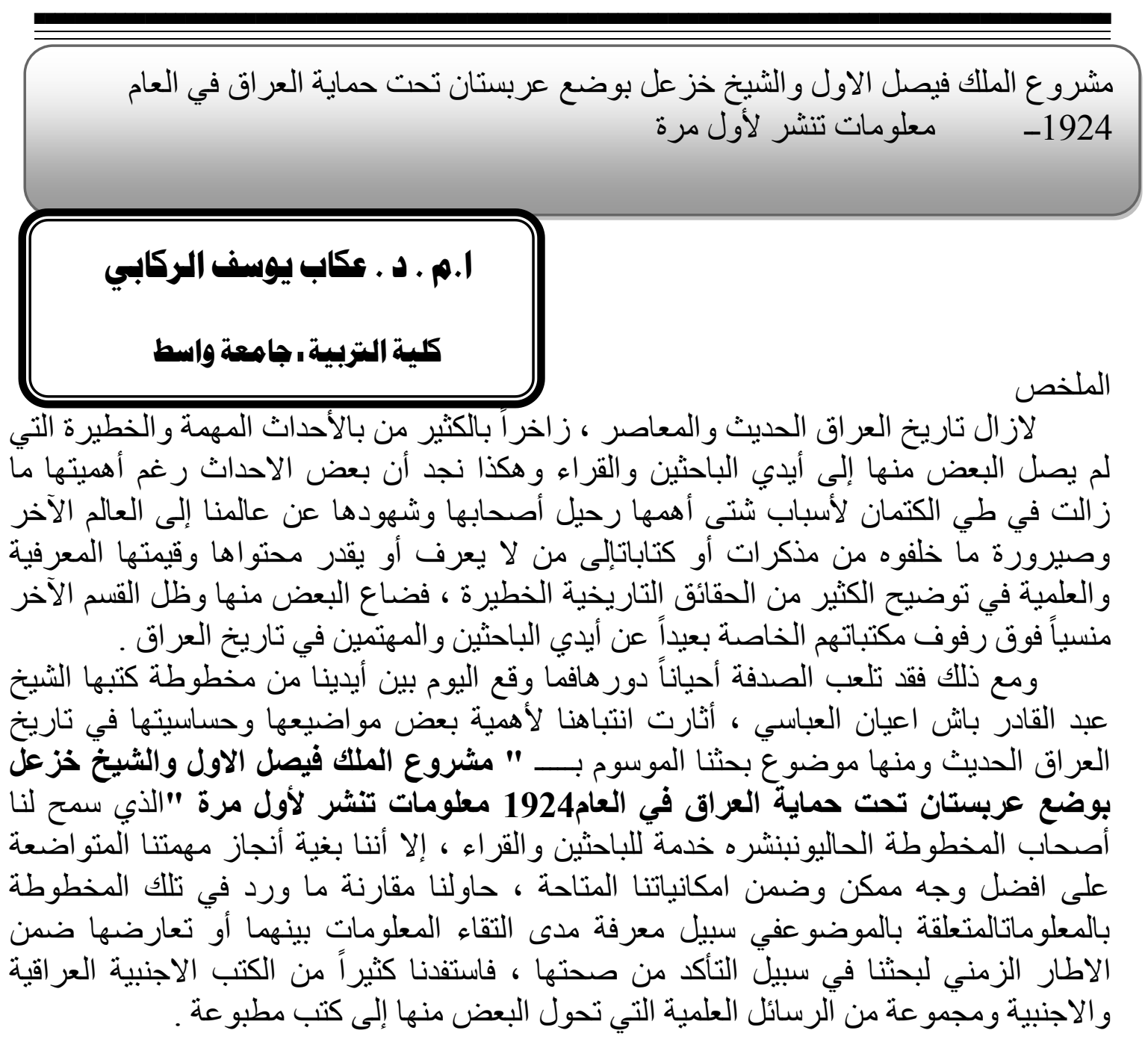

\title{
Abstract
}

Iraq's, modern \& contemporary history still fills with many important $\&$ dangerous events. Part from these events wasn't available for the researchers \& readers, for the sake of careful consideration $\&$ displaying it to the audience or public; to enhance some facts $\&$ historical paths of this country or rejecting it.

We can notice that, in spite of the importance of these events the majority of them still unseen, because of many reasons like, the death of people who know these events. The transition or transferring of these events to another people who know nothing about the historical value of these events.

Part of these events was lost; the other was kept on the Library's shelf away from the access of the researchers $\&$ the interested people in the history of Iraq. 
Accident may play a great role in our eastern communities which didn't pay attention to these events.

Today we have a cursive was written by Sheikh Abd Al QaderBaishAyan Al Abbasi, which draw our attention because it consist so many important information about the modern history of Iraq. including the topic of our research paper ( The project of King Faisal I\& Sheikh Khaz'al to put Arbstan under the protection of Iraq 1924).

Information was released for the first time; the owners of this information gave us the green light to publish these information or events in order to make it accessible to everyone.

The main recourse of these information was the (cursive), in order to make our task in accurate way, we have put our humble abilities to make a comparison between the information already exist in the (cursive), with the related information to find out the common issues \& the conflict between them within the time frame to find out its authentication \& reliability.

A great benefit was achieved from the Iraqi \& foreign recourse \& thesis part from these becomes book.

\section{Assistant Professor:}

\section{AukhabYousif Al Rekhabi}

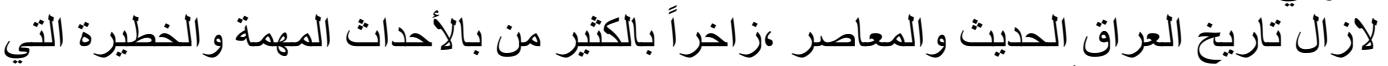

مدخل معرفي

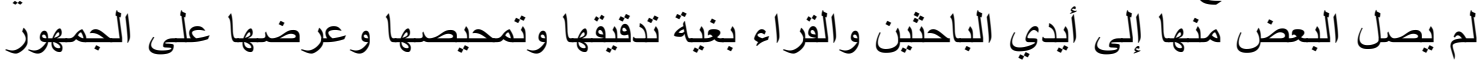

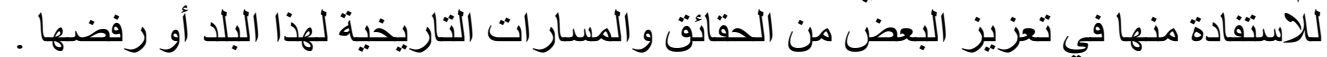

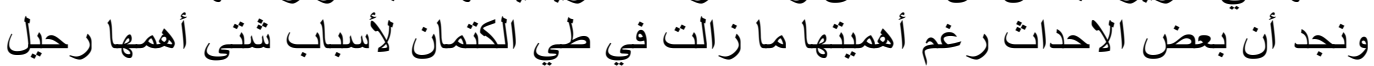

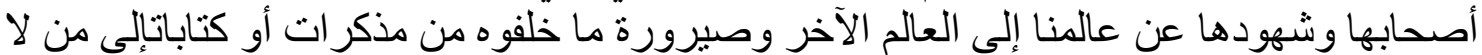
يعرف أو يقدر محتو اهاوقيمتها المعرفية و العلمية في توضيح الكثير من الحقائق التاريخية الخطيرة

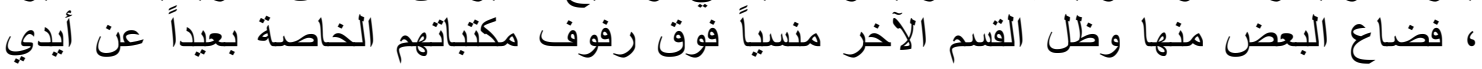

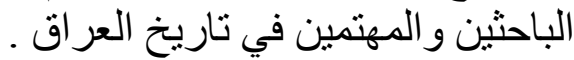
ومع ذلك فقد تلّعب الصدارفة أحياناً دور ها في مجتمعاتنا الثرقية التي لا تعير أهمية للوثائق

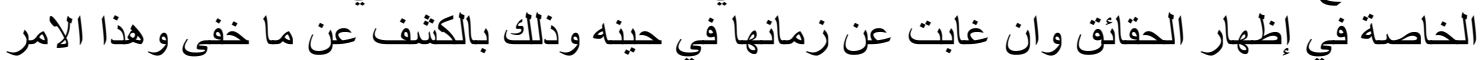

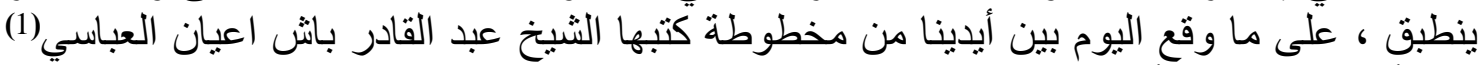

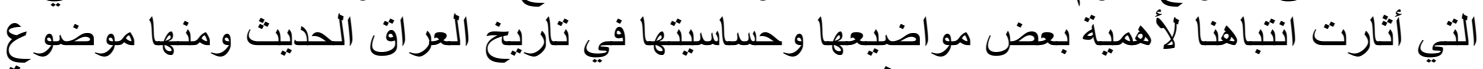

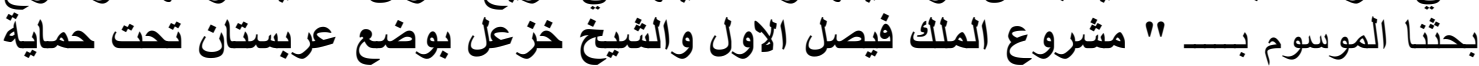

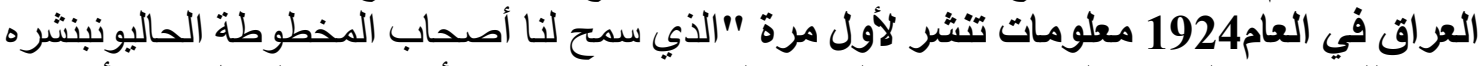

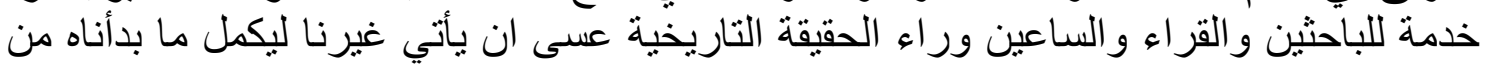


مشو ارنا ويكثف ، عن وثائق جديدة تضيف حقائقاً أخرى تضع النقاط على الحروف وتزيل الغث

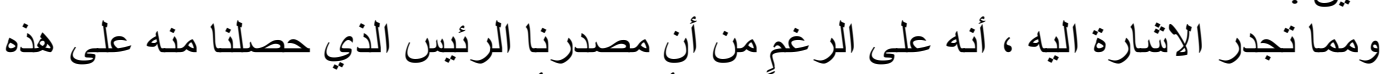

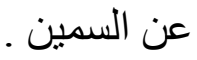

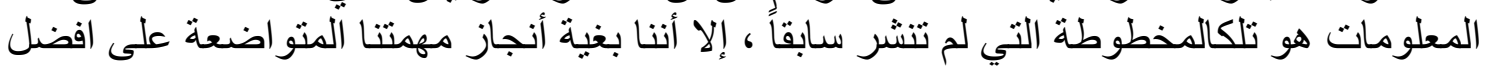

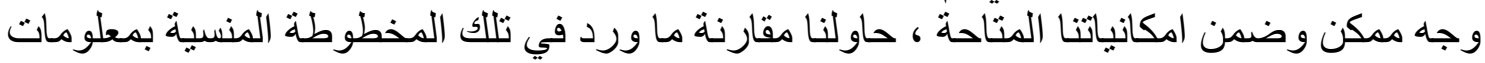

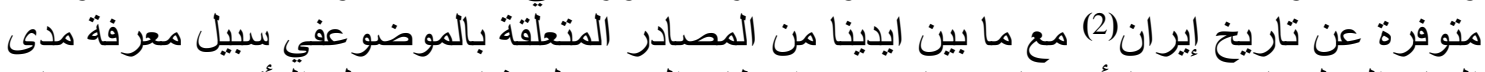

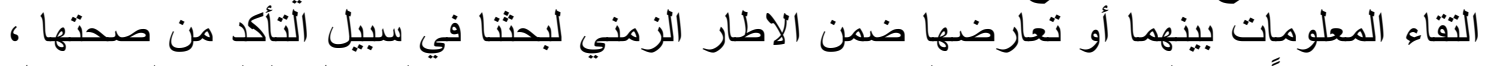

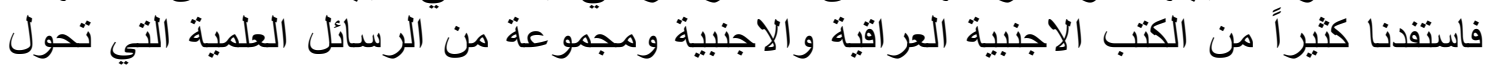

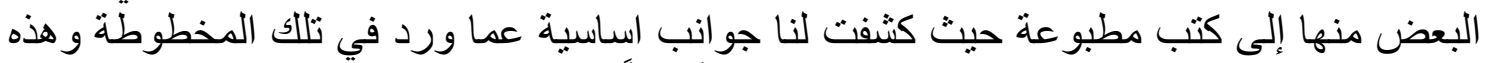

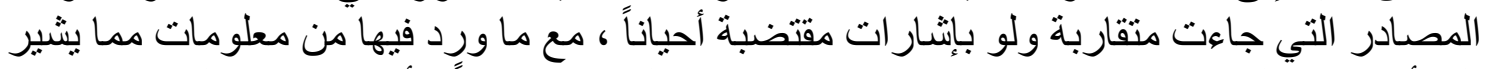

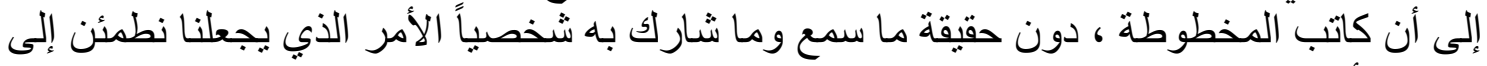

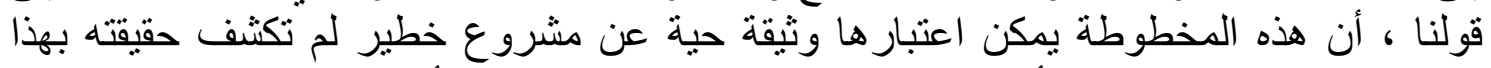

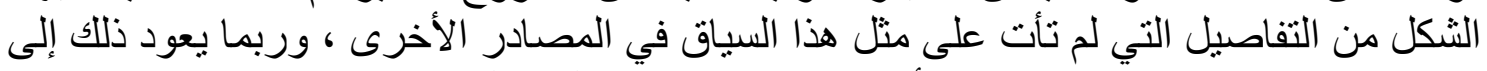

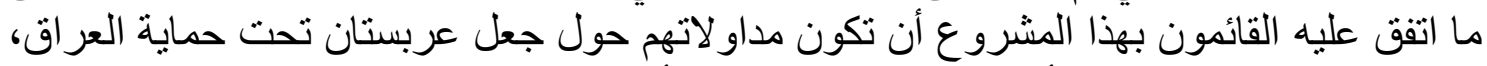

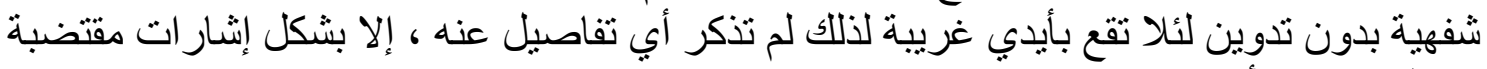
واود أن اشير بصى . بصورة خاصة إلى مؤلفات كل من الدكتور مصطفى عبد القادر النجار

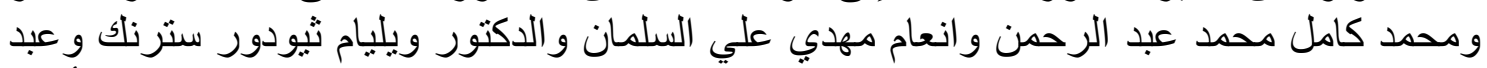

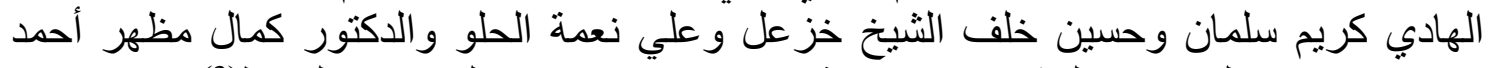

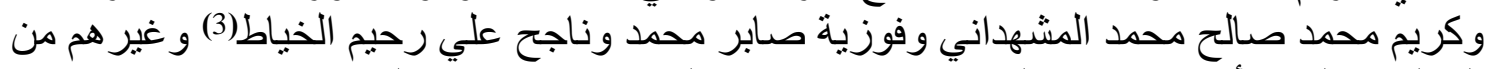

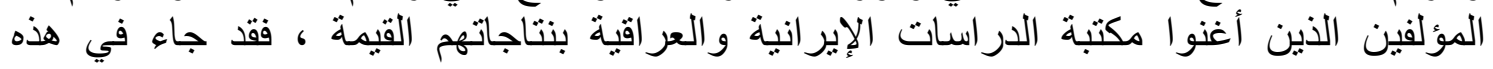

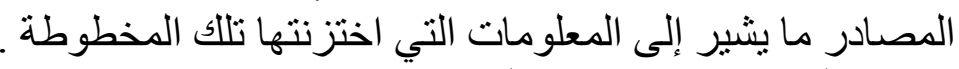
وصف المخطوطة وتدقيق معلو ماتها ليس الغرض من هذا العنوان هو تدقيق أو تحقيق كل مل ما ورد في أوراق تلأك المخطوطة

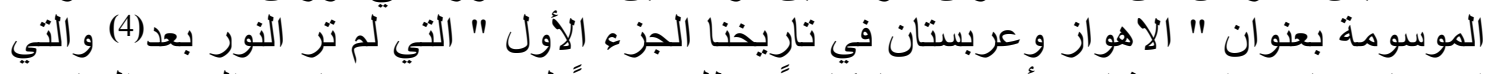

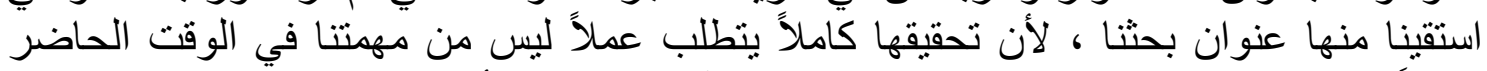

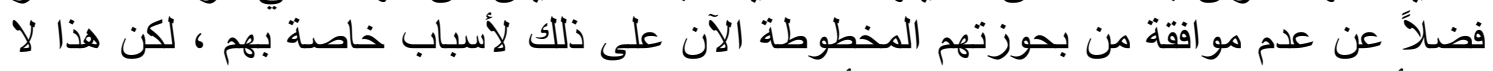

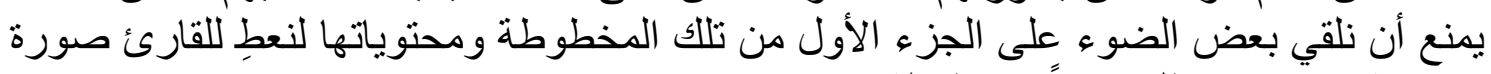

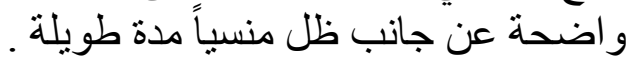
فالمخطوطة كتبت بخط واضنح جميل رغن رغن صغر حروفها وقد ابتدأت صفحتها الأولى ألى

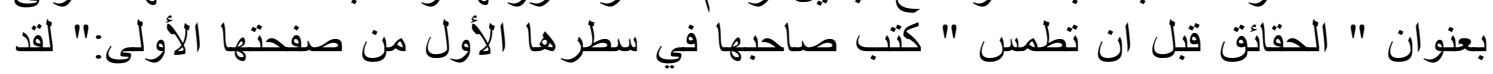

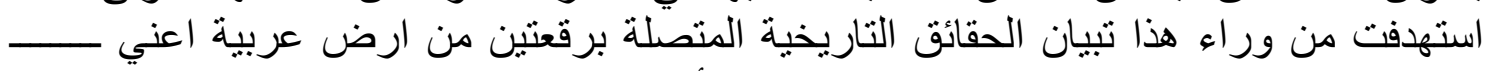

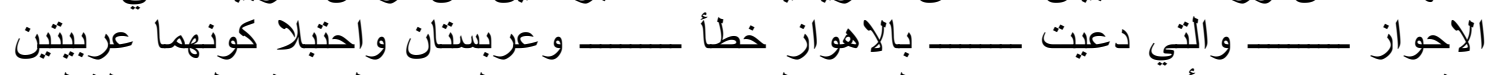

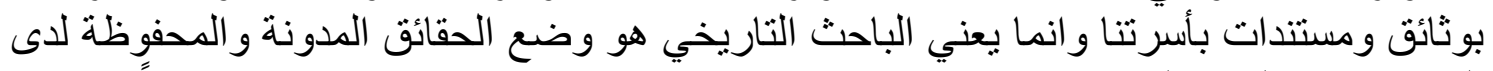

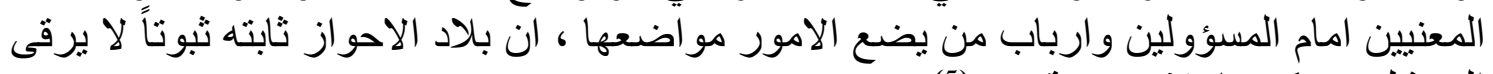
اليه شك في كونها بلاد عربية ...." (5) . 
وقد تناولت المخطوطة وبشكل مركز ، تاريخ أرض أمارة عربستان السياسي و الاقتصادي

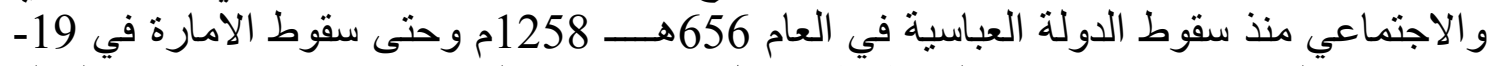

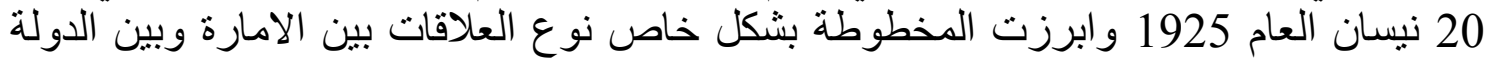

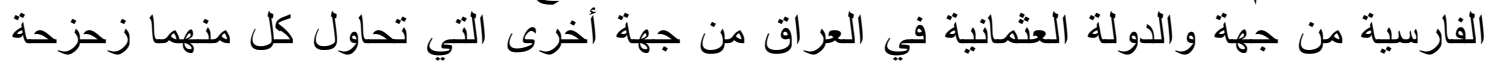

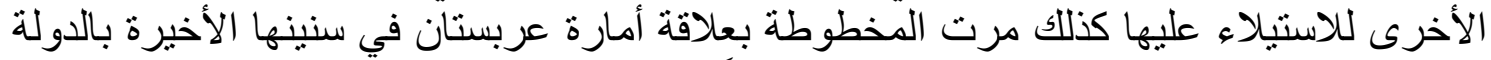
العر اقية التي انبتقت في 23 آب العام 1923 فضلاً عن تناولها مو اضيع التهار أخرى نحن في غنى عنها

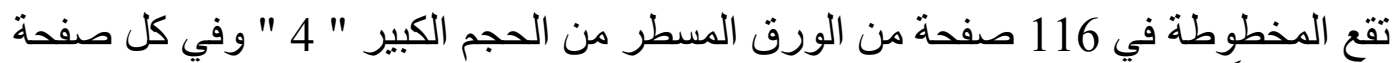

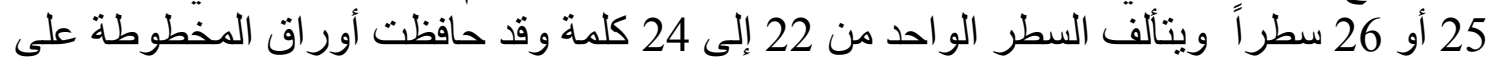

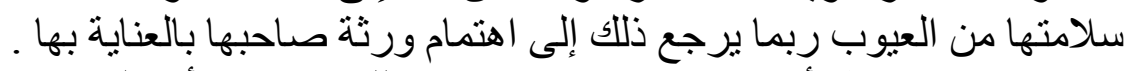

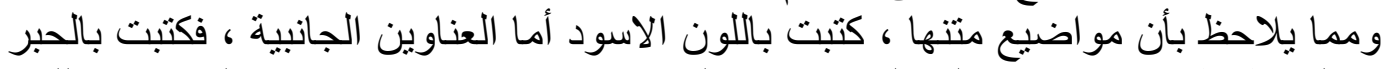

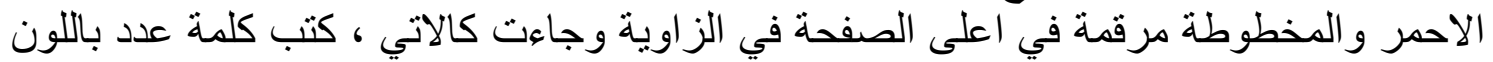

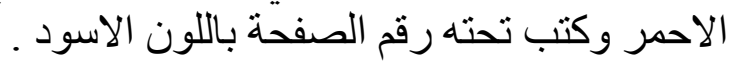

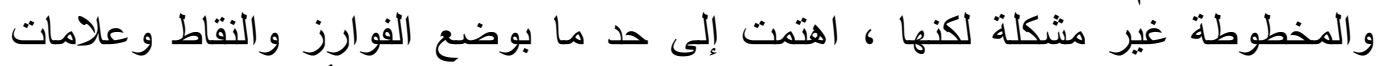

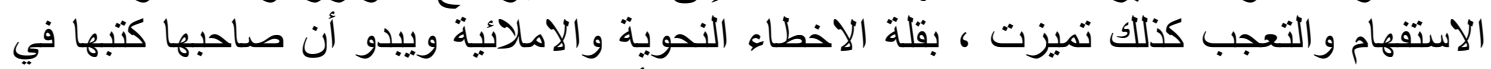

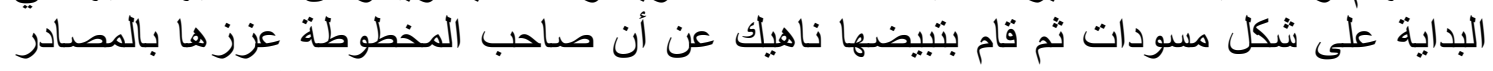

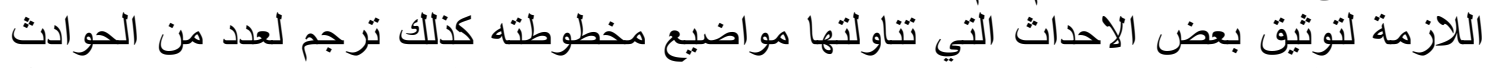

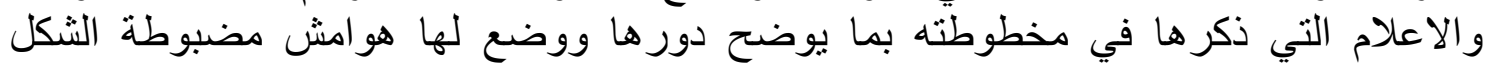

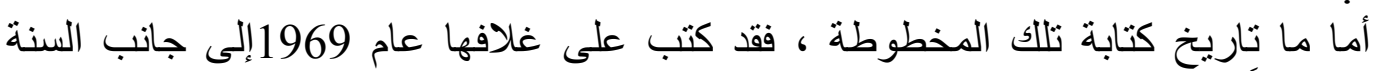

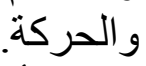

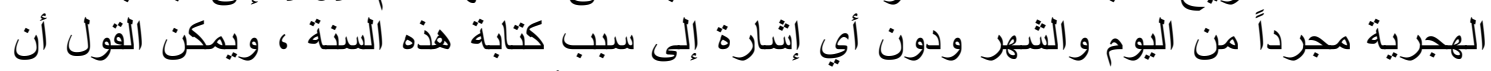

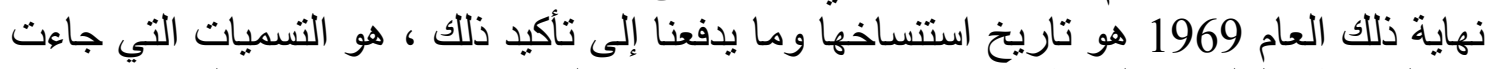

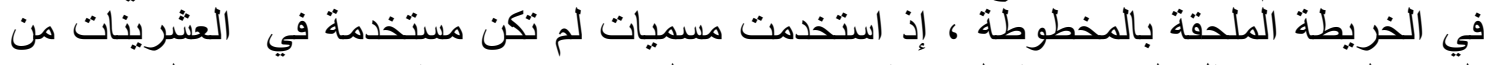

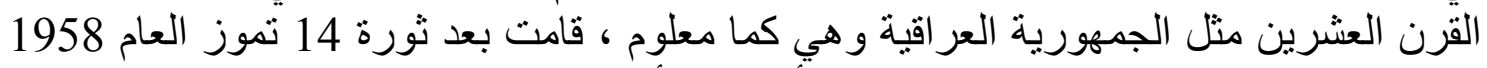

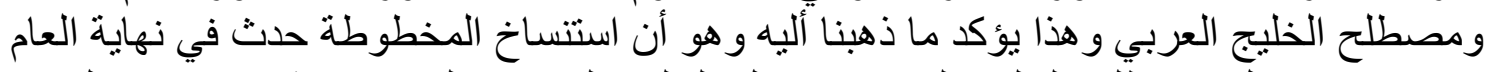

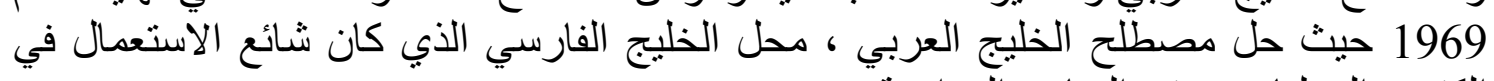

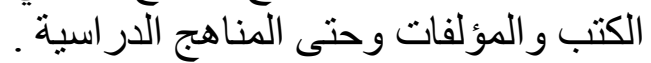

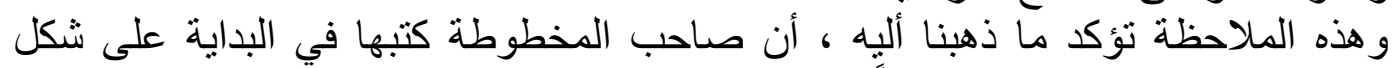

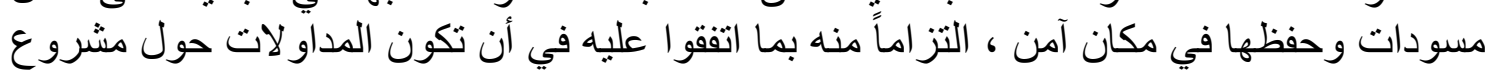

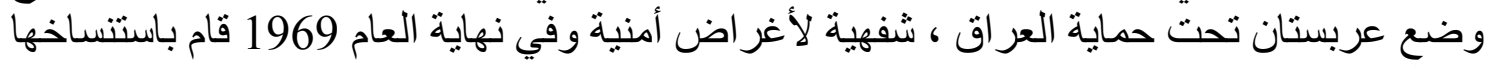

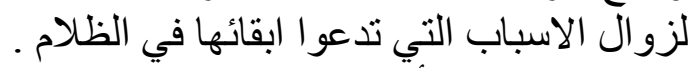

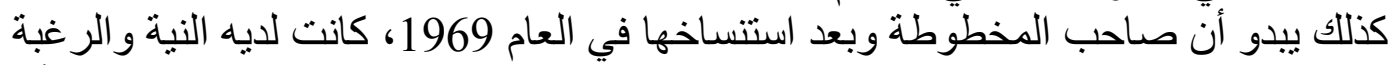

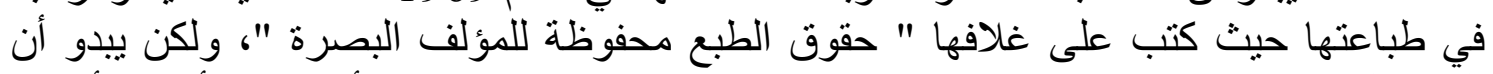

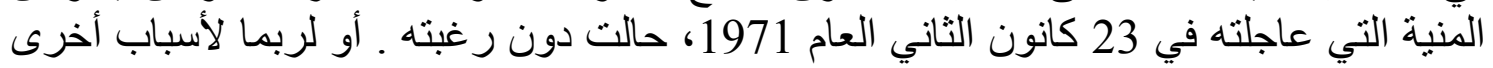

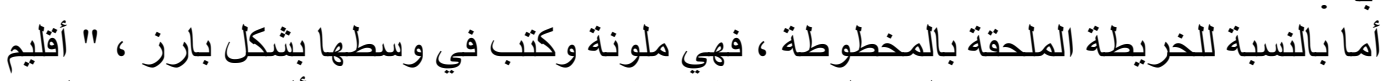

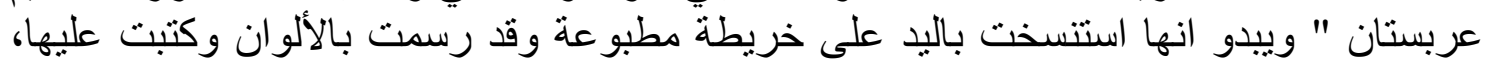




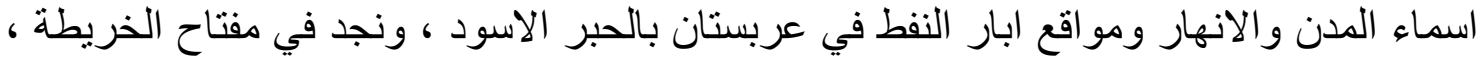

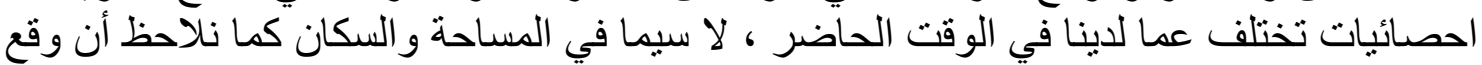

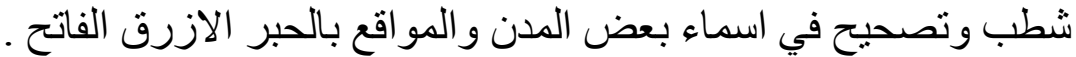

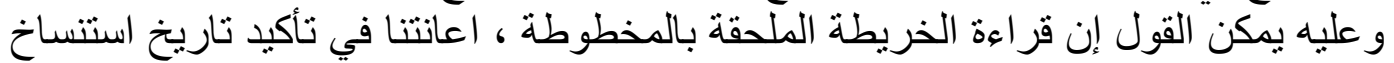

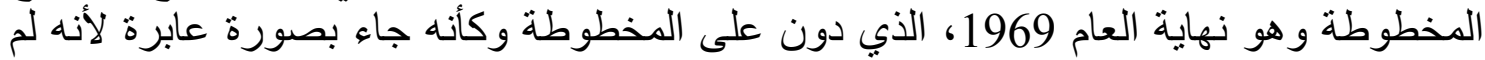
ولكن" الثيء الثيء الذي بمكن ملاحظته من سير الحوادث ، أن صاحب المخطوطة كان شاهداً يثر إلى شيء .

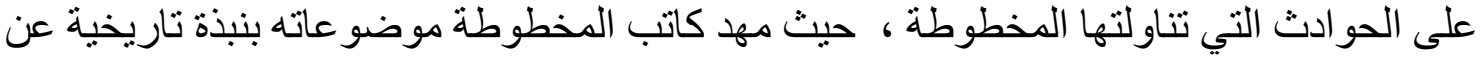
عربستان وتاريخها منذ القدم حتى العصور الحديثة ثم ذكر الاحداث التي ساهم بمداو لاتها ومنها

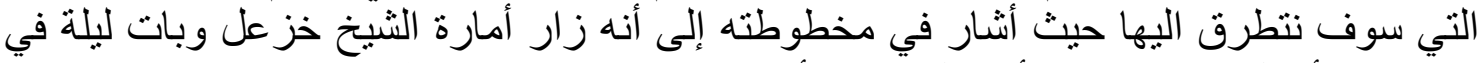

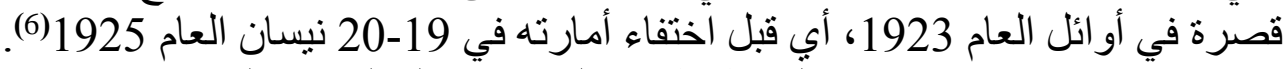

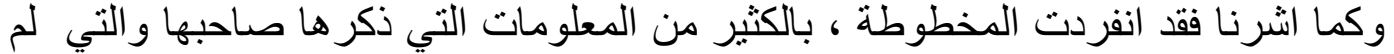

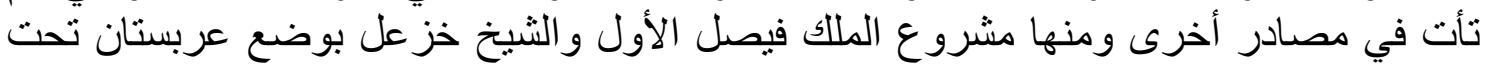

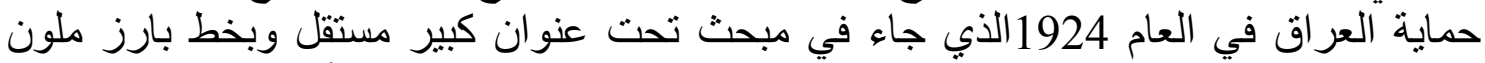

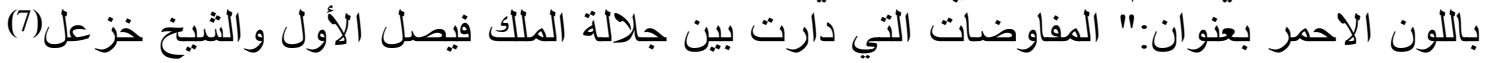
خان بو اسطة الثيخ صالح باش اعيان العباسي(8) في بغداد تهدف إلى جعل عربستان تحت الحت حماية

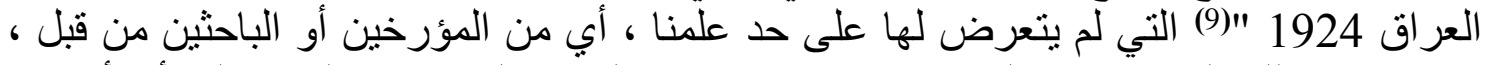
حيث بقيث تلك الحادثة طي الكتمان وسر من اسرار التاريخ لحقبة من الزمن إنى إلى أن أن أوقعتها

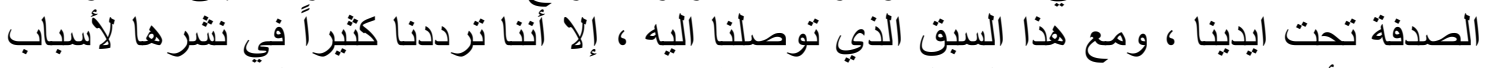

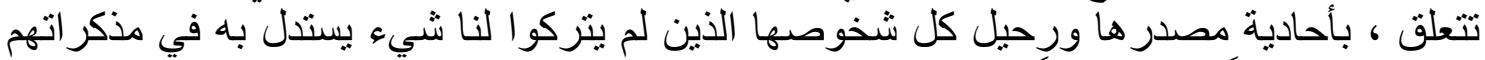

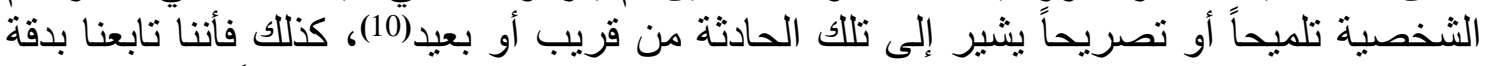

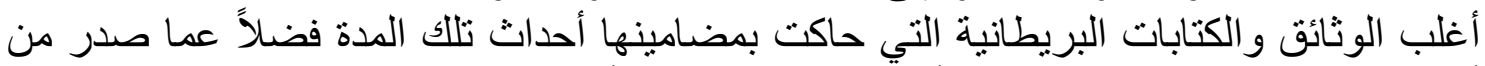

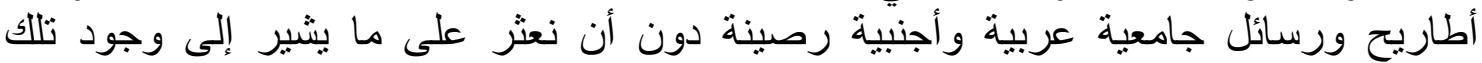
القضية(11)، بالثكل الذي أطرته تللك المخطوطة ، سوى اشتار ات أو ايماءات عن محاولات اتل الملك

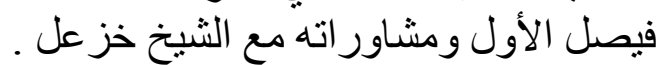

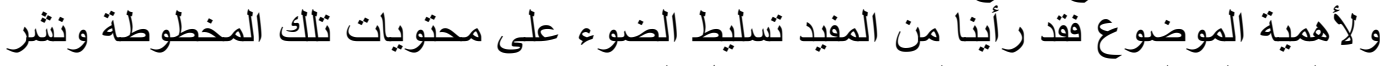

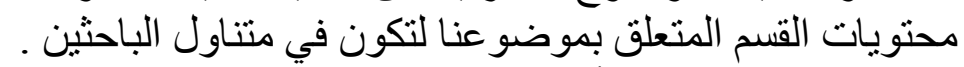

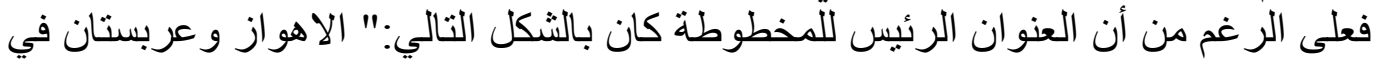

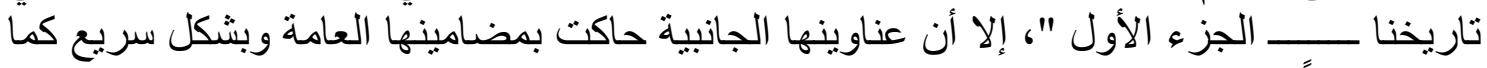

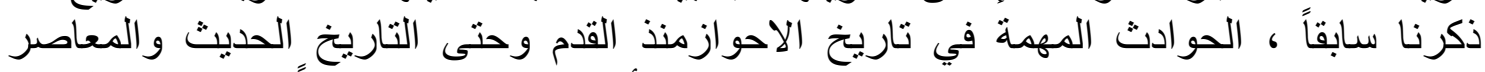

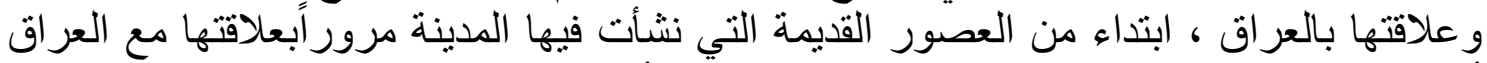

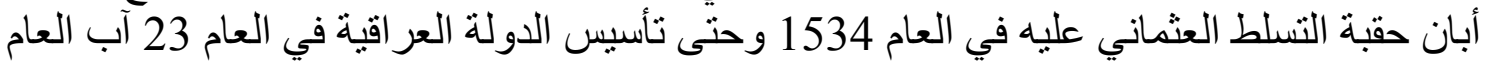

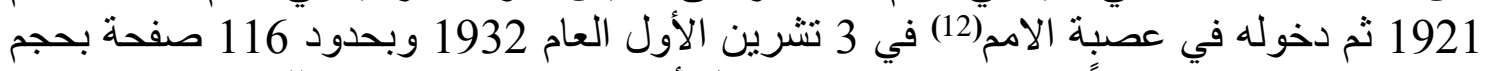

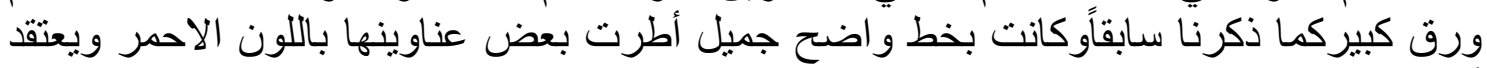

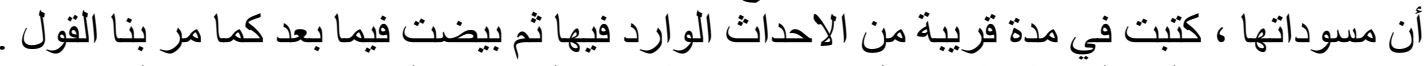

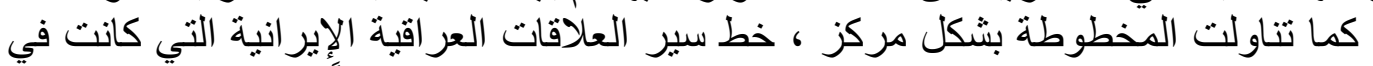

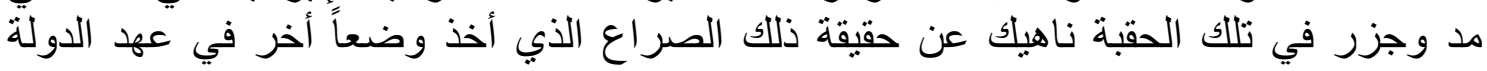


العر اقية الجديدة التي انبثقت في 23 آب العام 1921(13)، بعد أن تداخلت الخنادق في هذا الصراع

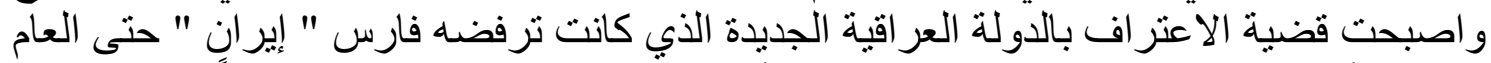

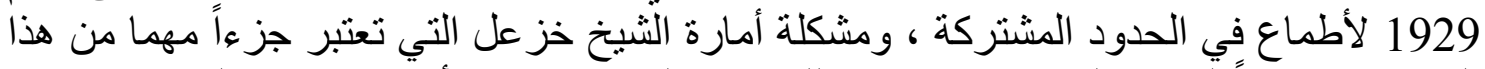

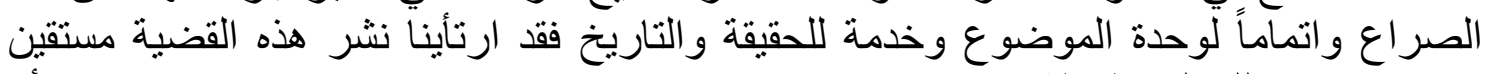

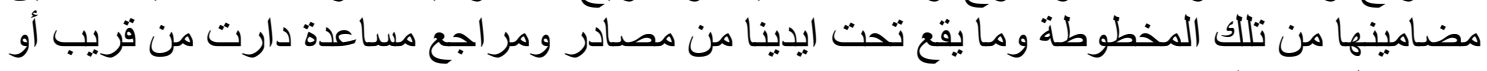

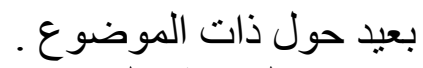

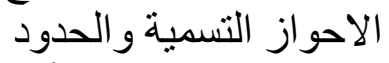

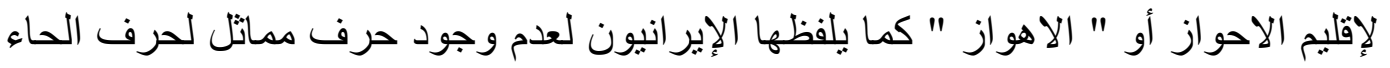

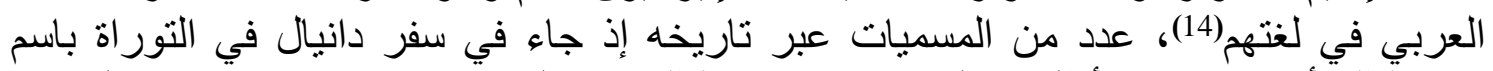

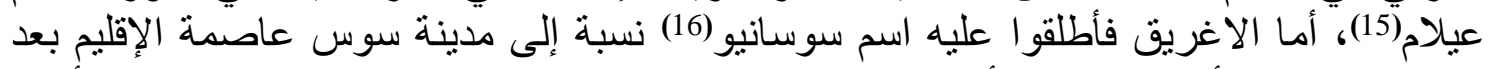

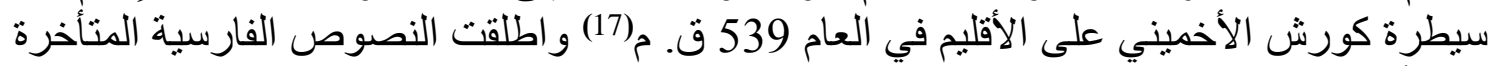

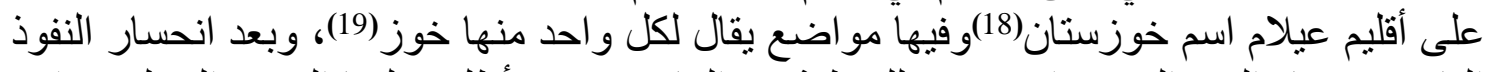

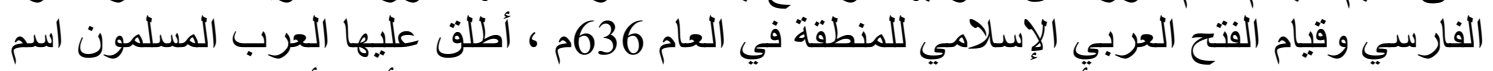

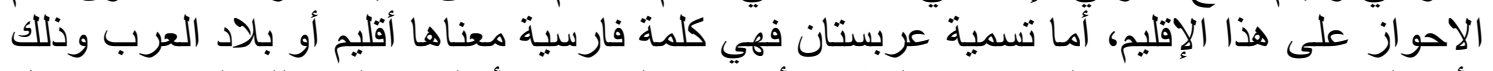

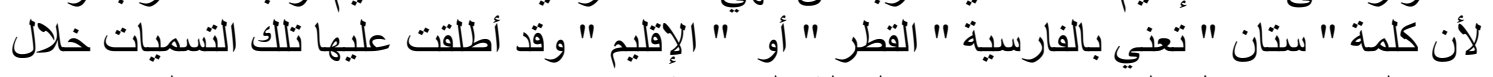

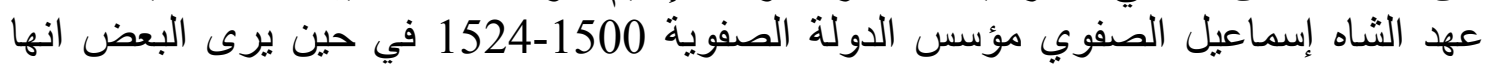

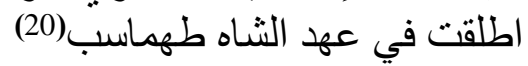
ومهما اختلقت الآراء في هذه التسميات ، فهي تنشير وتؤكد إلى أصل الإقليم وسكانه ، أنهم

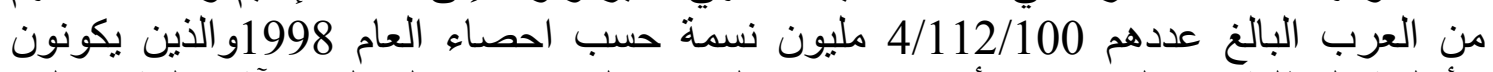

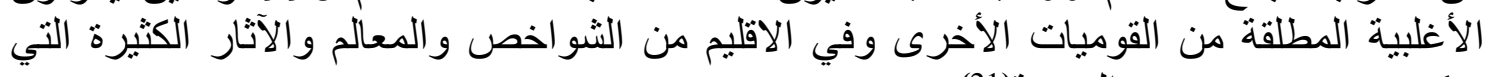

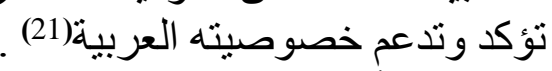
وقد أجمع الباحثون الذين زاروا المنطقة التي يشكل العرب فيها الغالبية العظمى من سكانها ،

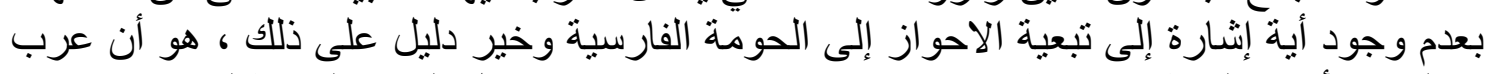

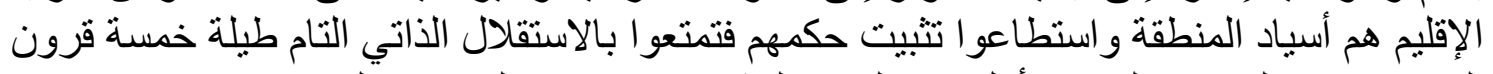
إلى ان اضمحلت في الربع الأول من القرن العشرين حيث تم الحاق الإقليم عنوة في 20 نيسان

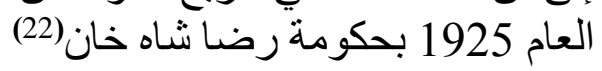
يتميز اقليم الاحواز بموقع استر اتيجي متميز ، كونه جزء به من المنطقة التي تمثل نقطة التقاء

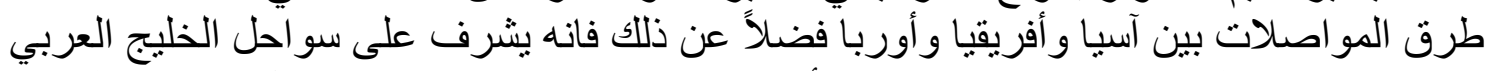

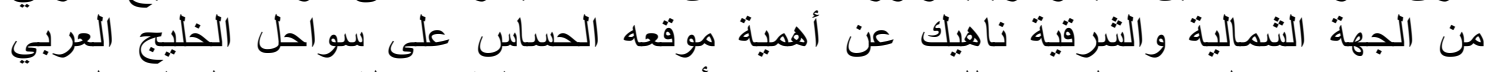

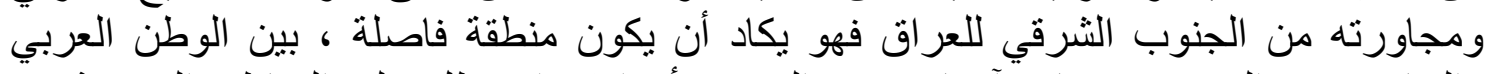

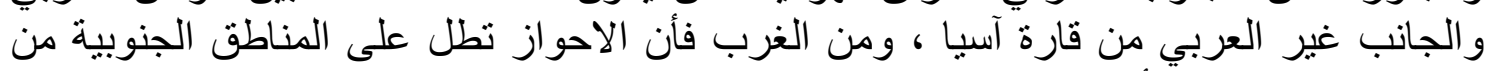

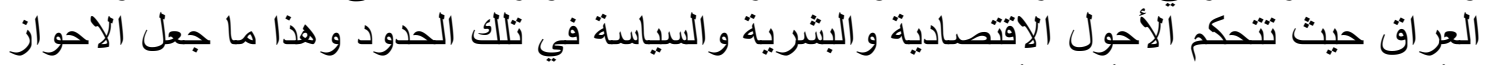
متأثرة بتلك المناطق في أغلب أحو الهان الهاب(23) .

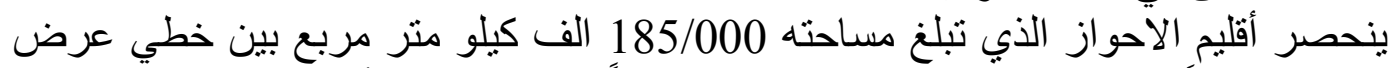

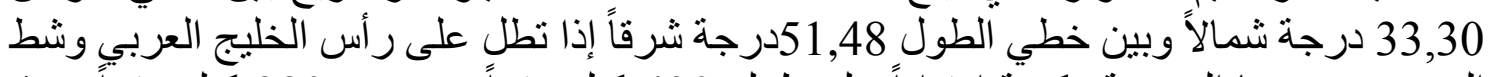

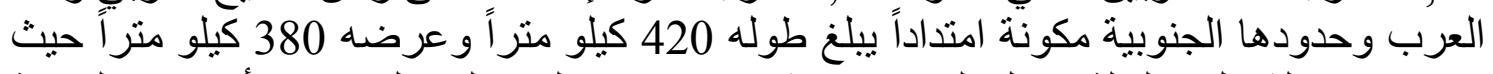

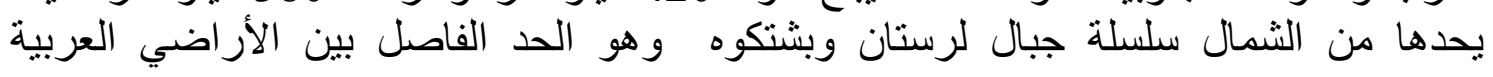


و الأراضي الفارسية ومن الثرق امتداد جبال البختبارية وهي جزء من جبال زاكروس وهذه بـإه

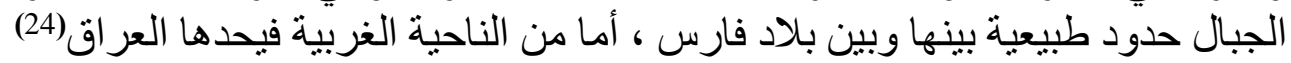

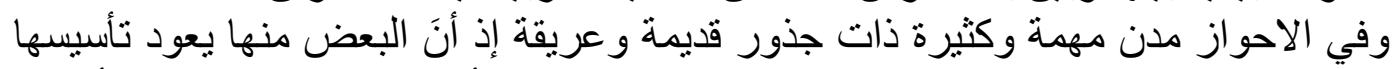

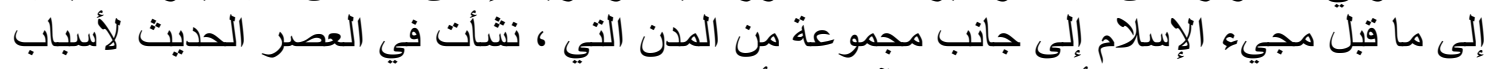

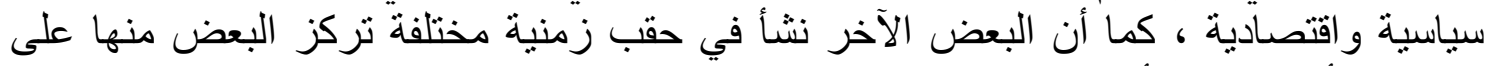

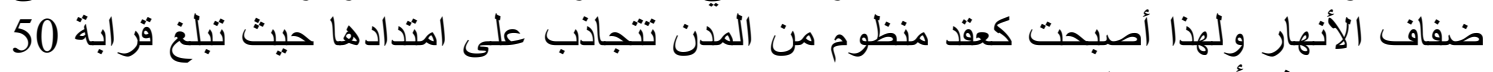
خمسون مدينة و أهم مدنها فهي: الاحواز التي تعد عاصمة الاقليم و التي تقع في الثمال الثرقي من مدينة المحمرة(25)التي تقع

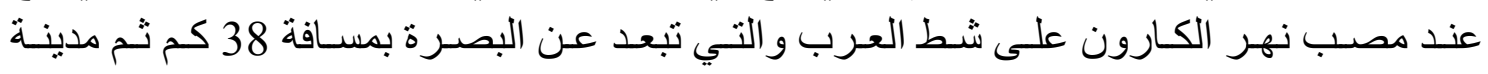

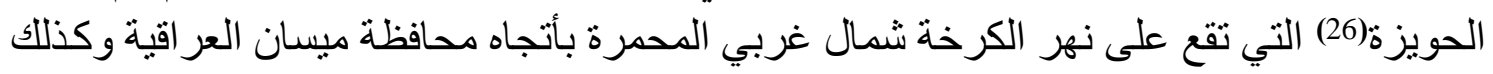

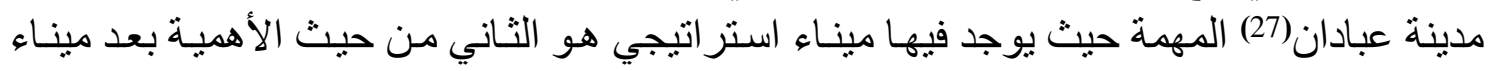

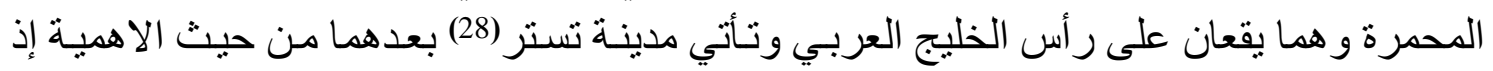

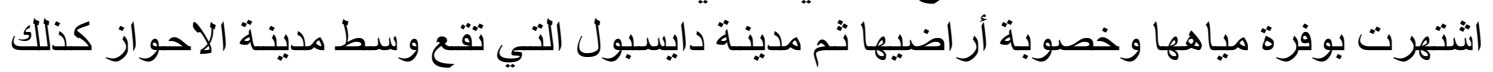

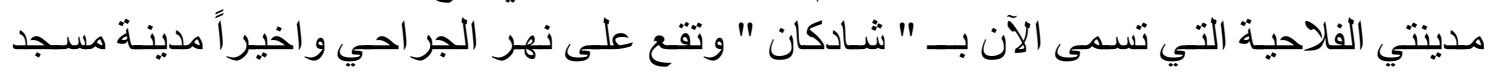

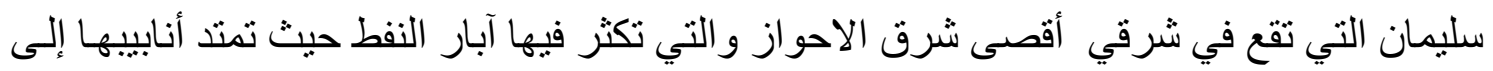

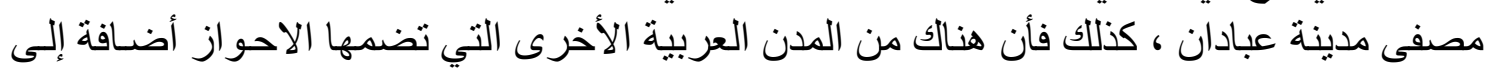

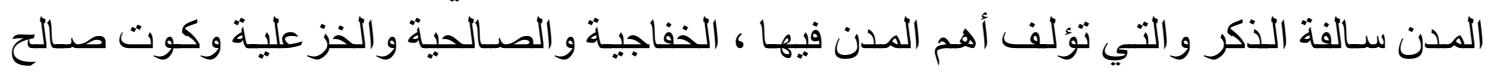

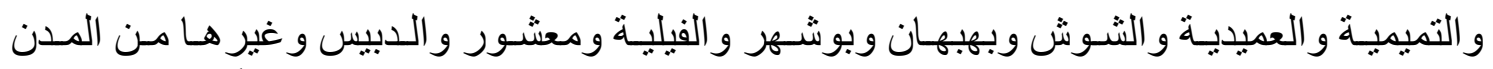

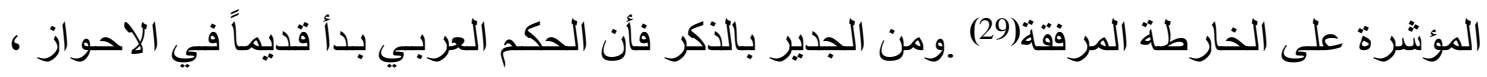

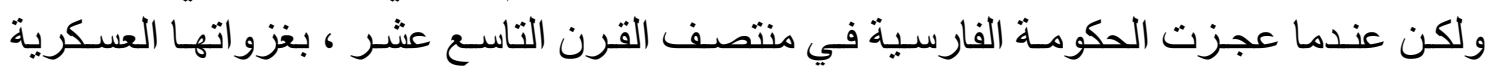

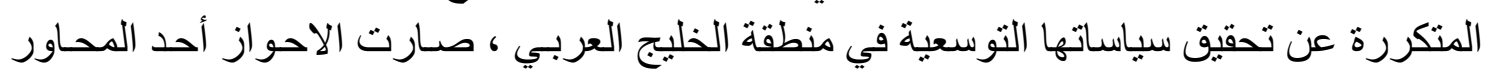

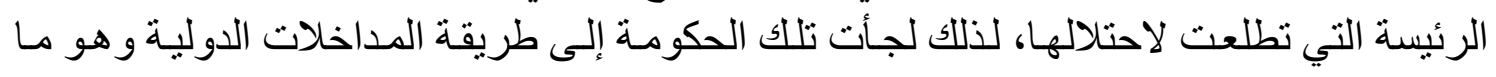

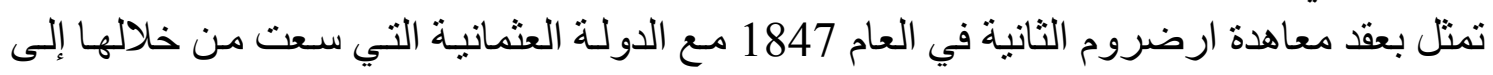

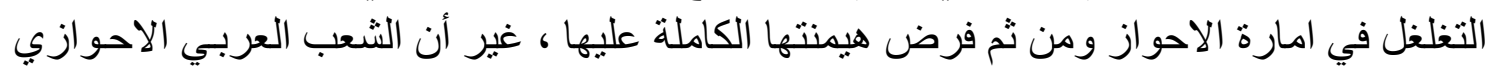

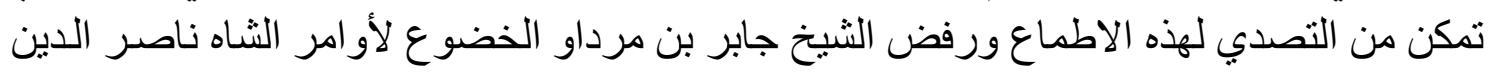

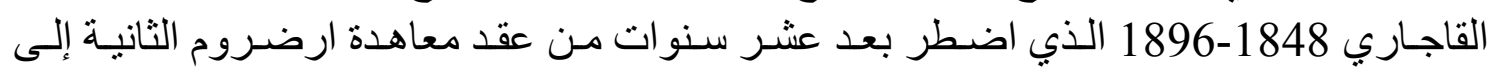
الاعتر اف بأمارة الثيخ جابر وهذا حصل الثيخ المذكور على الاستقلال لأمارته في العـام 1857 بإصدار المرسوم الملكي من قبل الثاه ناصر الدين القاجاري جاء هاء فيه:

$$
\begin{aligned}
& \text { 1- ت تكون أمارة الاحواز إلى الحاج جابر بن مرداو و لأبنائه من بعده . }
\end{aligned}
$$

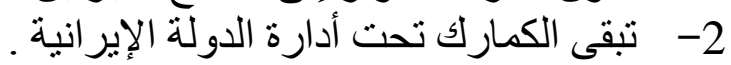

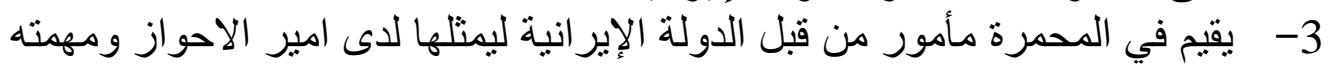
تنحصر في الامور التجارية فقط . 
4- بتعهد أمير الاحواز بنجدة الدولة الإيرانية في حالة اشتباكها بالحرب مع دولة

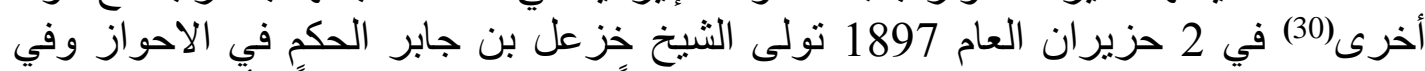

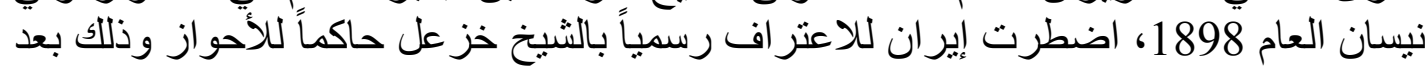

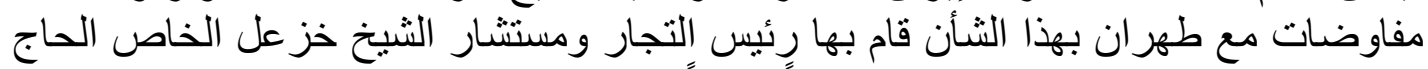

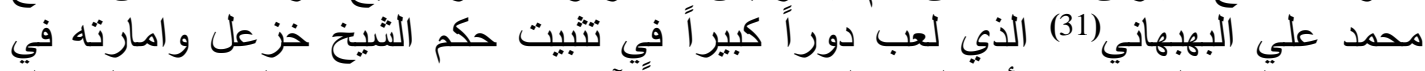

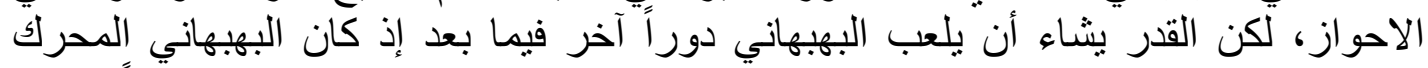

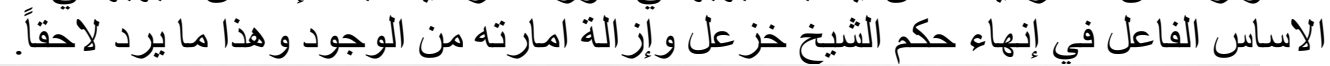

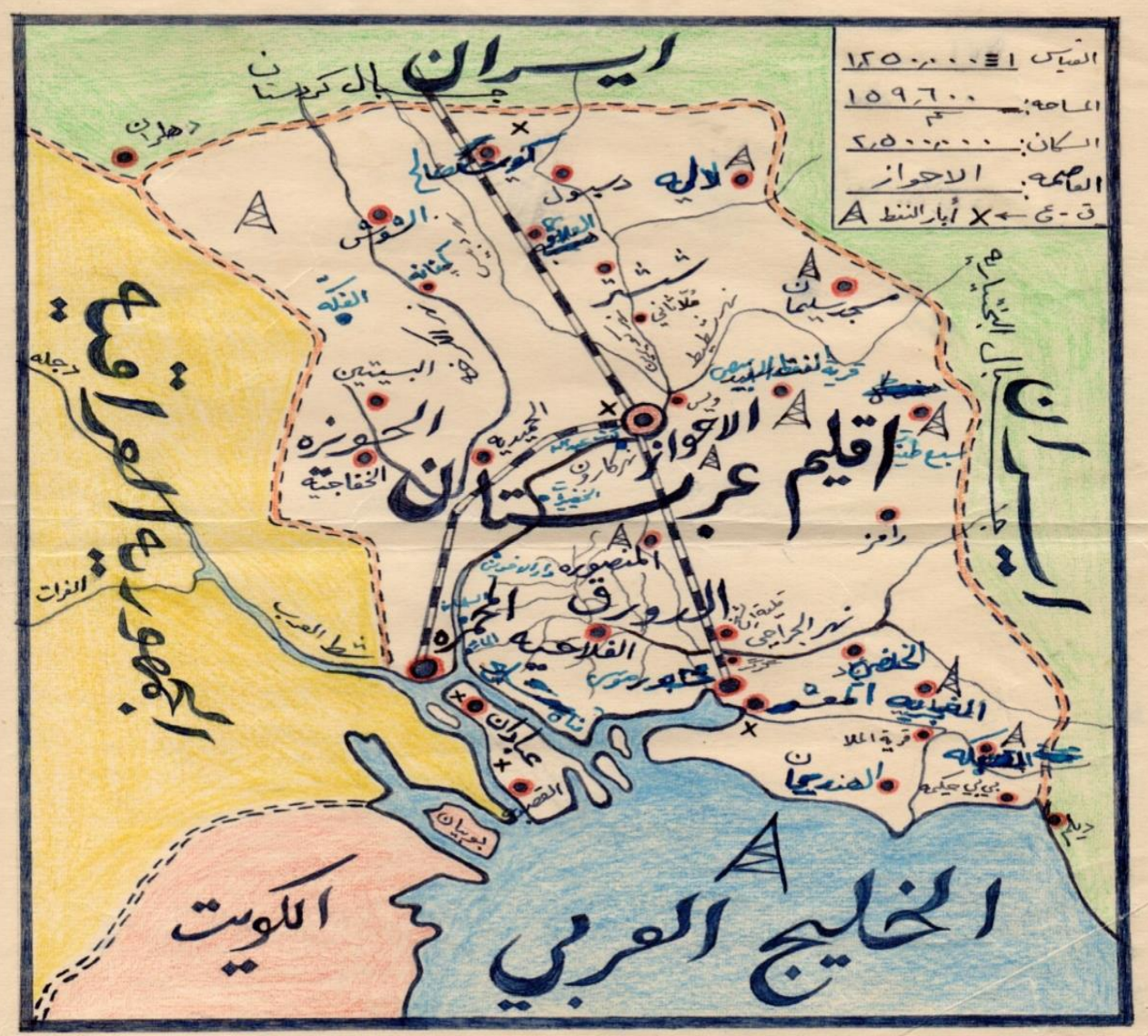

خارطة تبين الحدود الإدارية لعربستان ومدنهاويظهر عليها أيضاً ابار النفط و الانهار

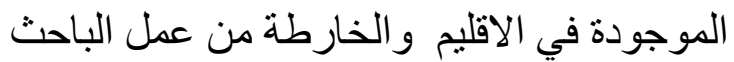

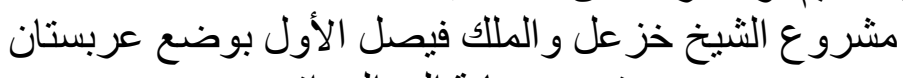
تحت حماية إلى العر اق المل 
إنَّ مضمون هذا المشروع يتلخص ، بأن يقوم العراق بمساعدة الثيخ خزعز علثيخ المحمرة

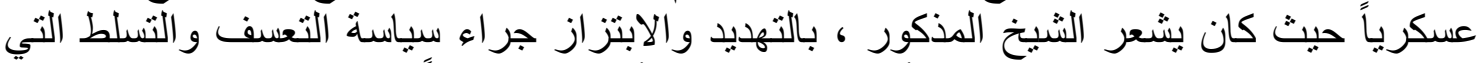

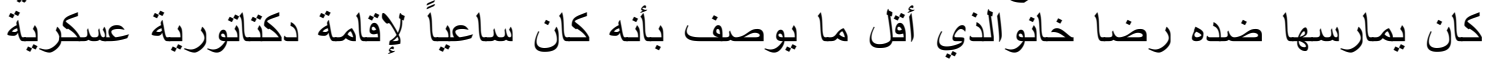

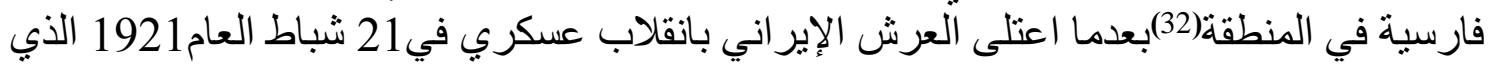

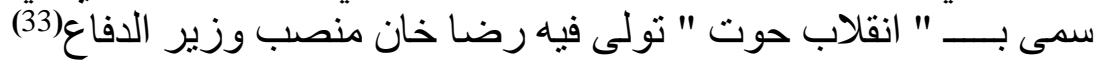

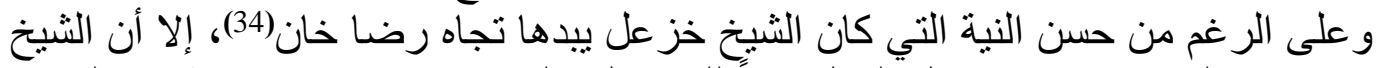

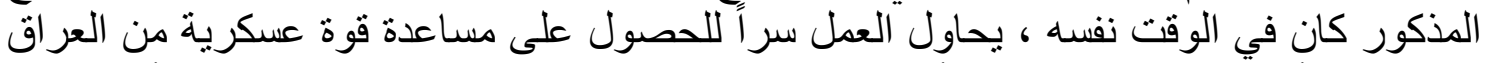

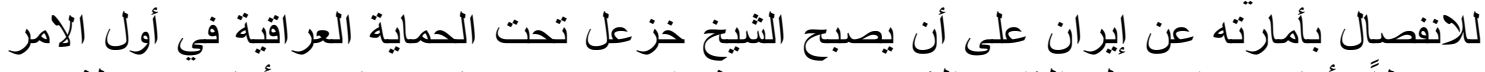

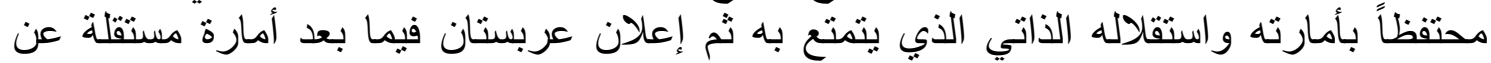
إيران(35)

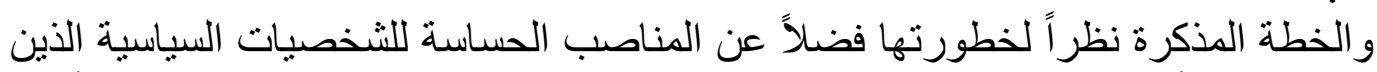

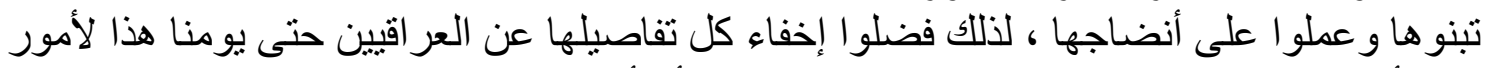

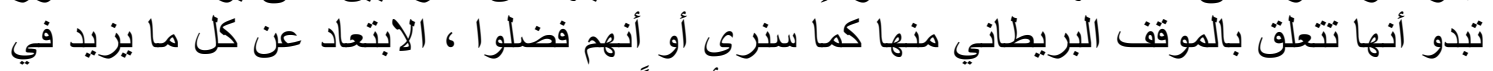

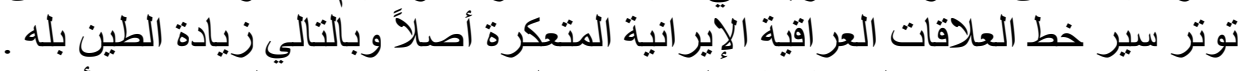

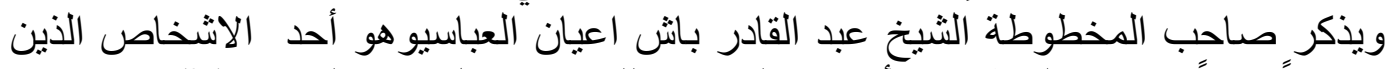

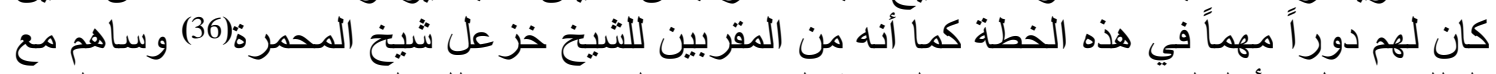

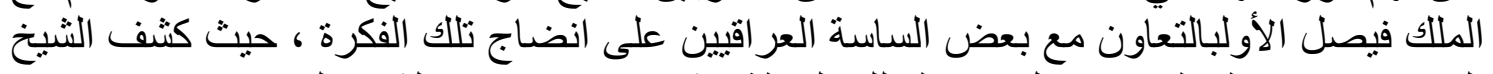

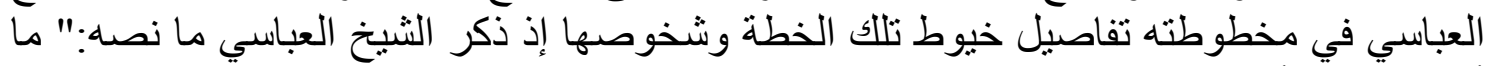

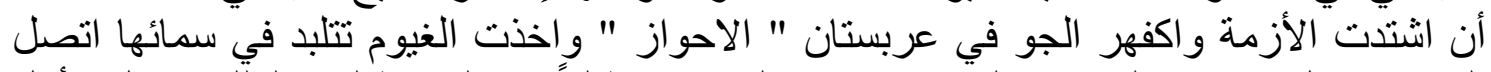

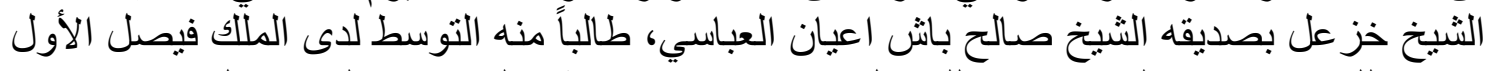

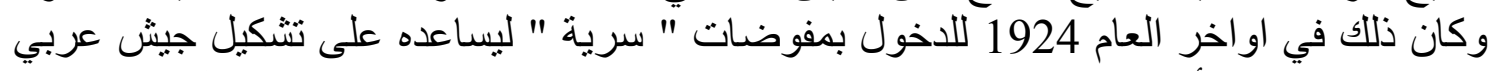

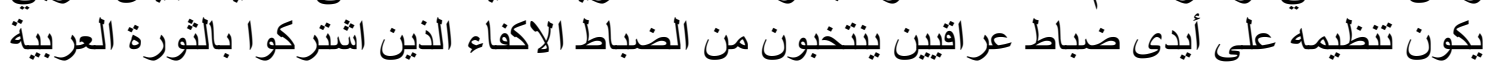

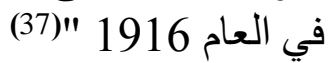

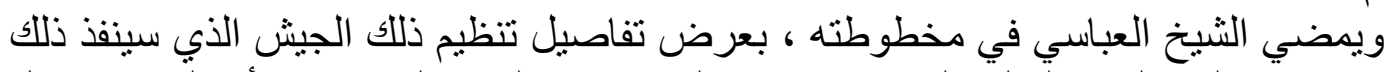

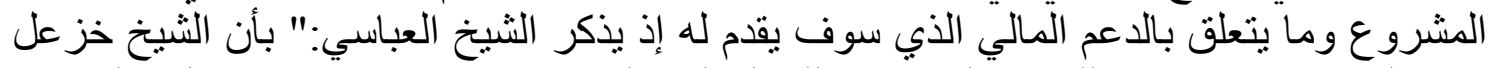

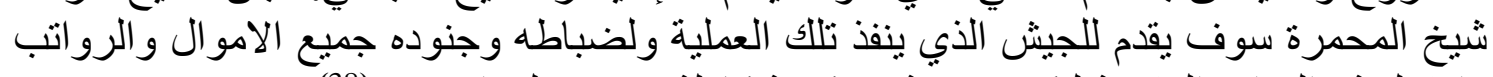
و الاسلحة و المدافع اللازمة لتكوين فرقة عسكرية كاملة تدرب على على ايديهم "(38) .

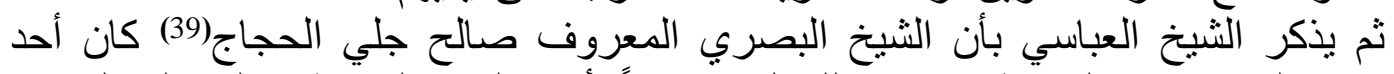

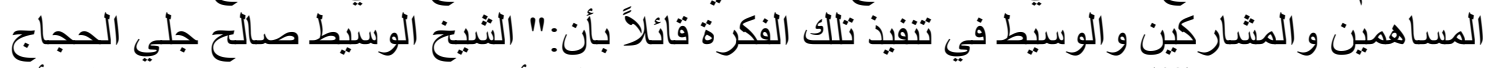

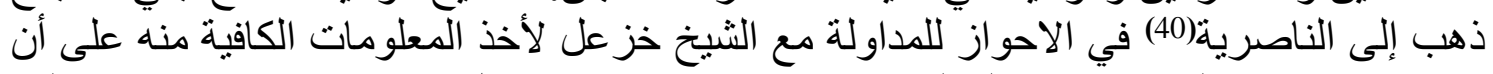

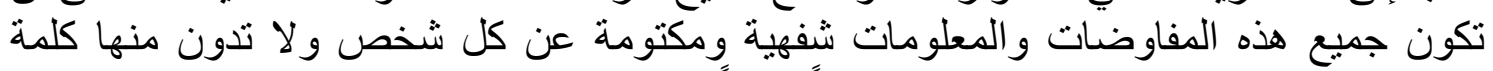

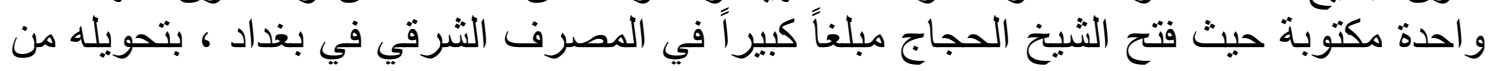

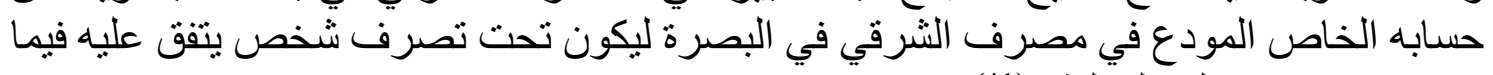
بعد إذ تم الاتفاق على العملية "(41) التودئ

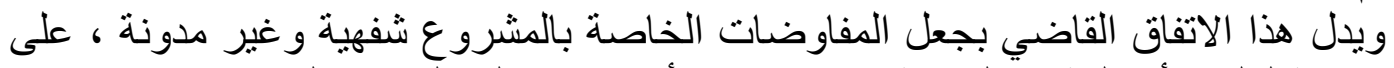
نباهة سياسية لعمهم أن الوثائق المدونة يمكن سرقتها أو تسربها إلى الجهات التئن التي تعنيها ، في حين 
أن الاتفاقات الثفهية يمكن نكر انها ونفيها لعدم وجود الدليل المادي عليها عند تعقد الاوضاع الدولية

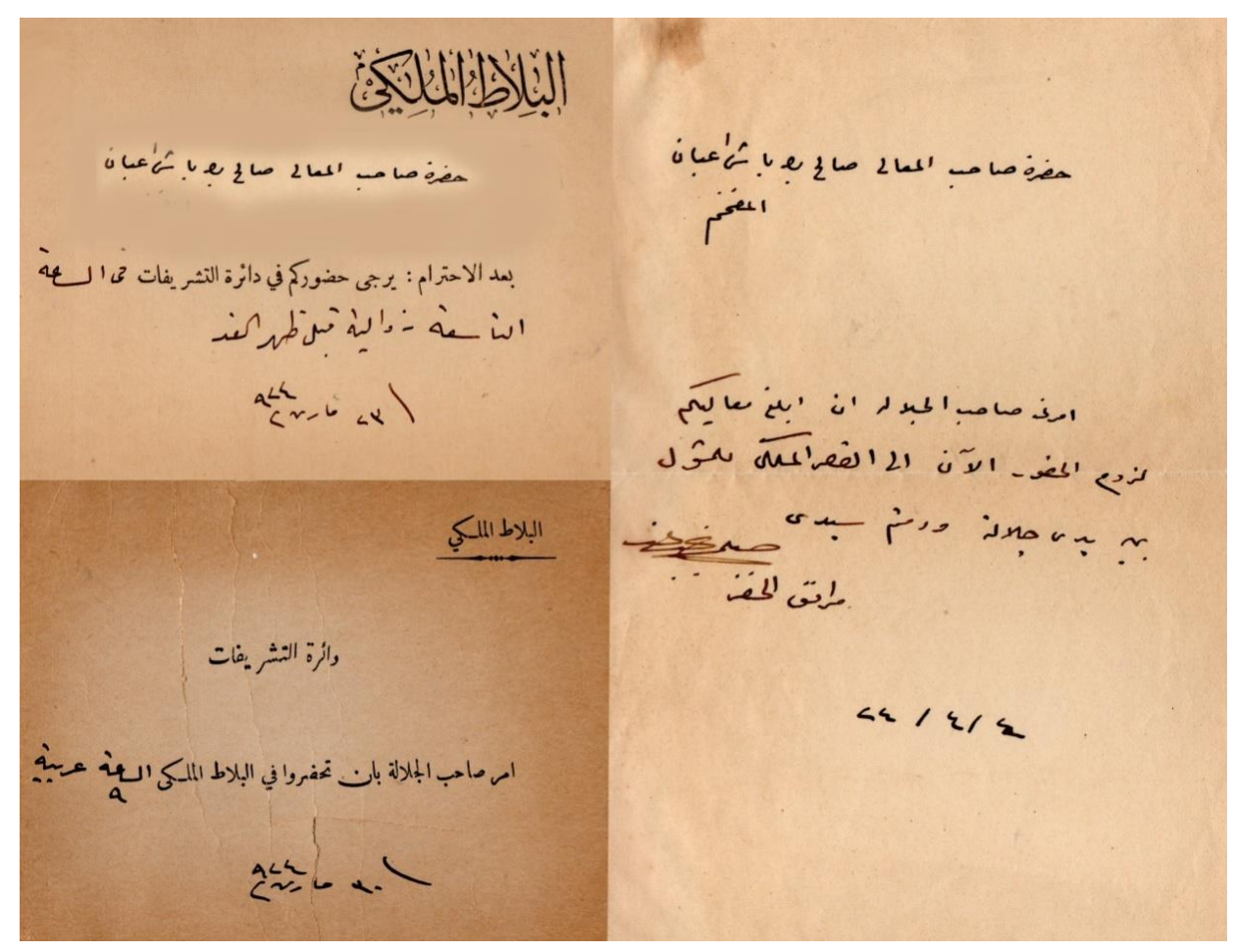

ثلاث دعو ات ملكية خاصة وجهها الملك فيصل الأول في العام 1924 إلى الثيخ صالح باش الثان

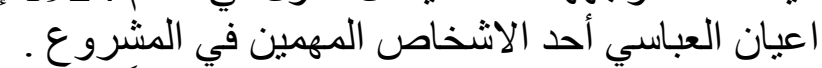

وزير الدفاع العر اقي جعفر العسكري والثيخ خزعل يعقدن إجتماعاً في المحمرة ويقررون الثين تشكيل فرقة عسكرية وتسير خطة جعل عربستانتحت حماية العراق بالخطوط التي رسمت لها من قبل القائمين

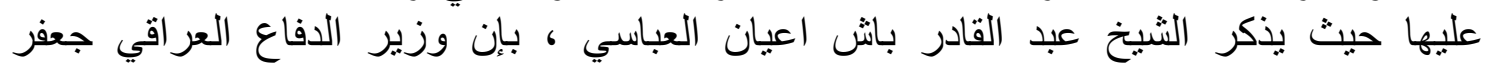

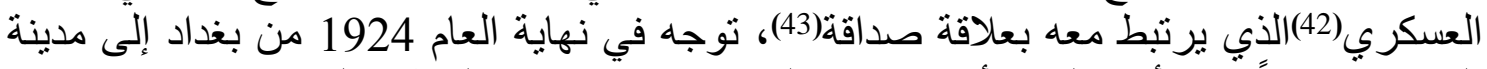

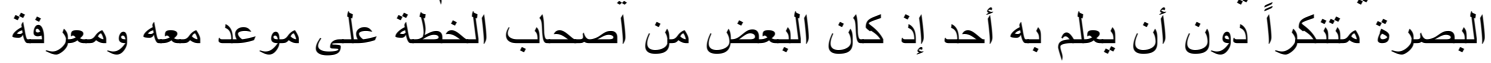

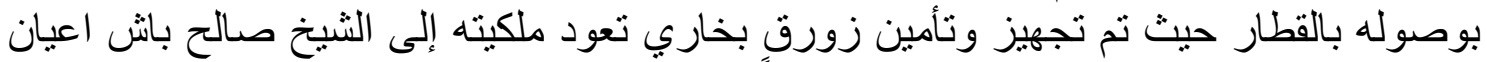

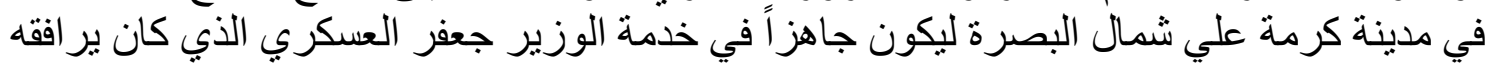

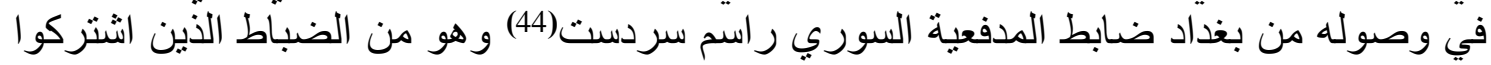

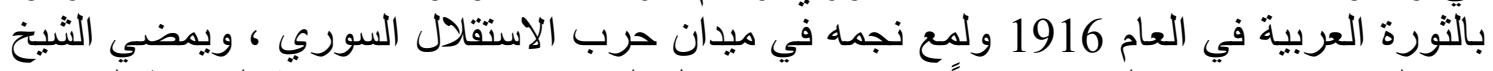
عبد القادر باش اعيان العباسي قائلاً:" انه وبعد وصول في فيدان العسكري من بغداد برفقة الضابط الَّوري السي 


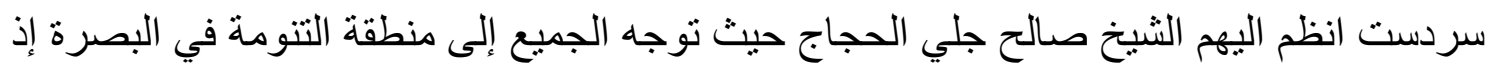

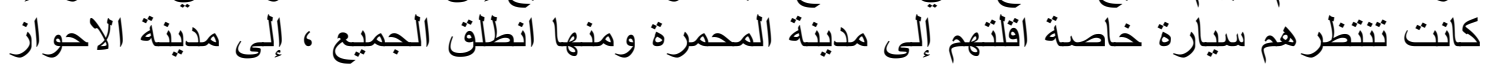

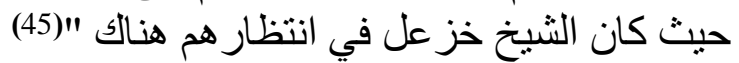

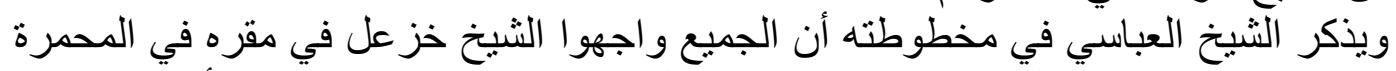

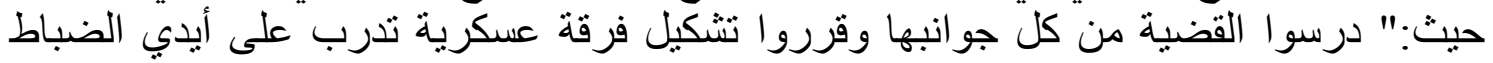

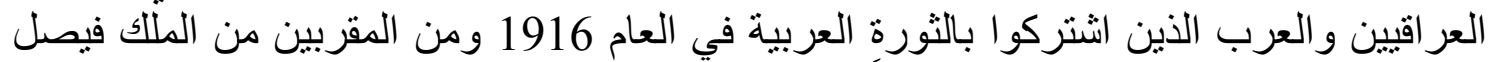

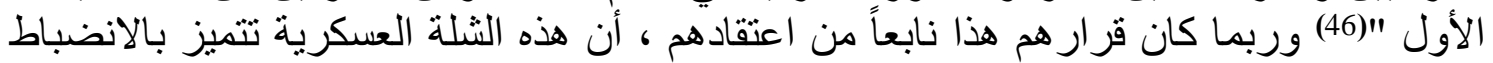

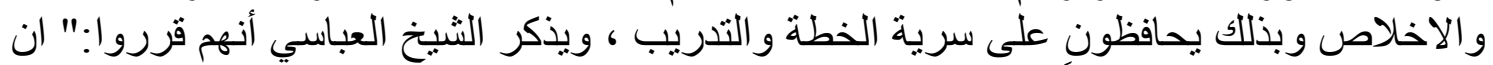

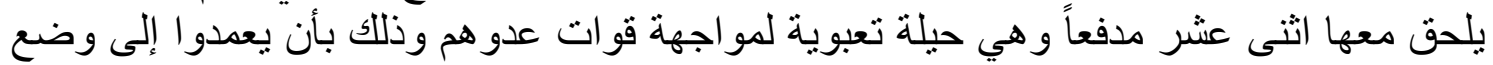

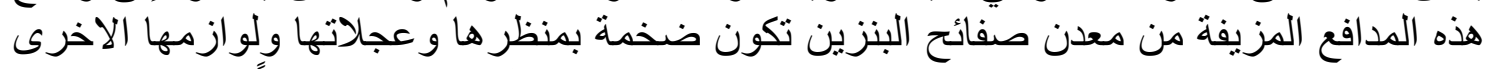

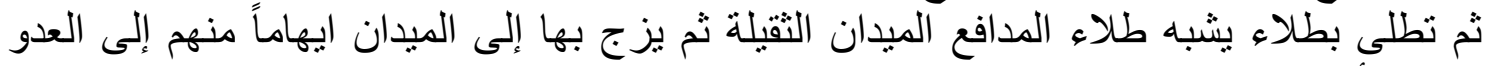

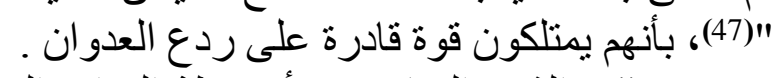

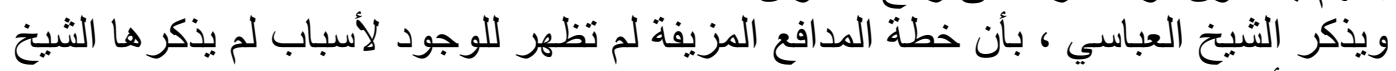

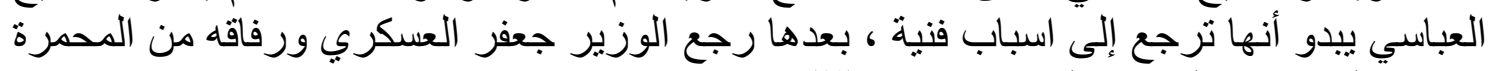

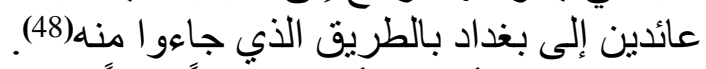

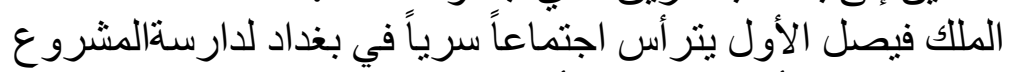

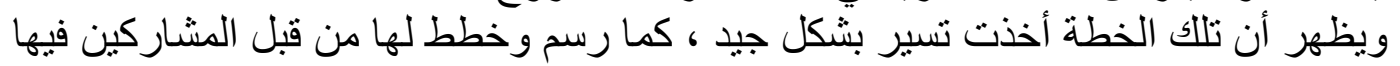

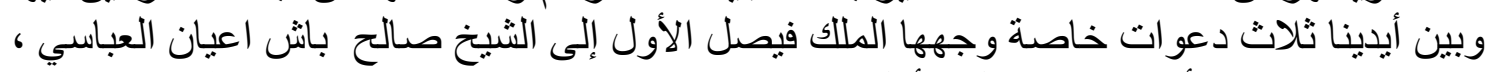

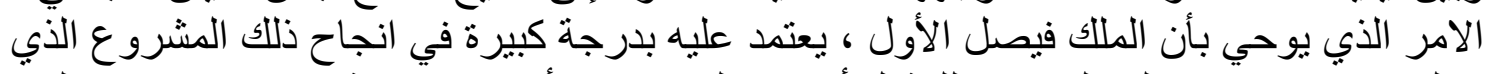

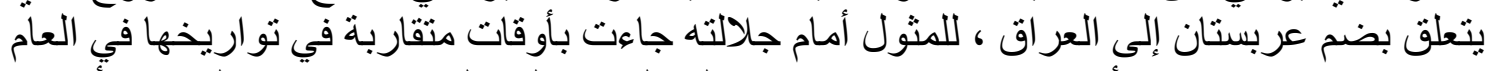

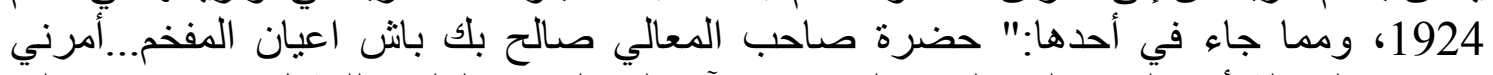

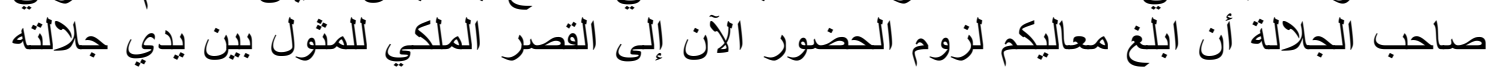

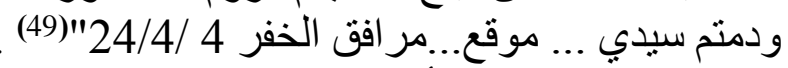

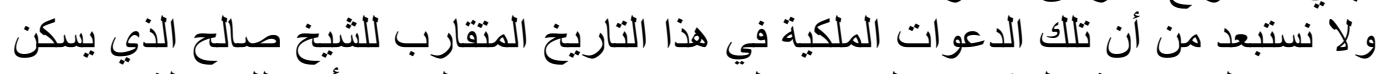

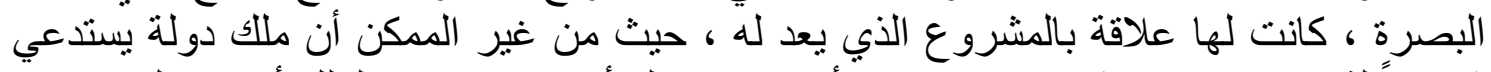

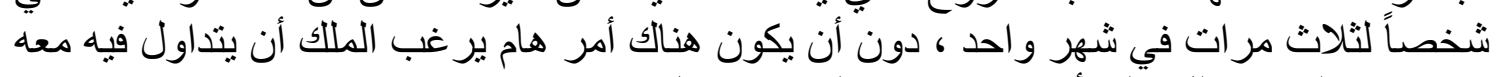

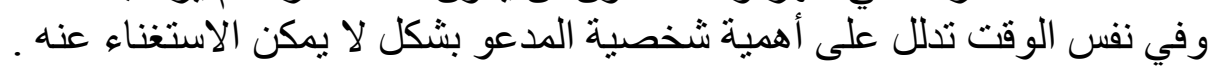

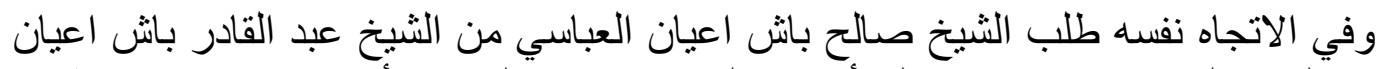

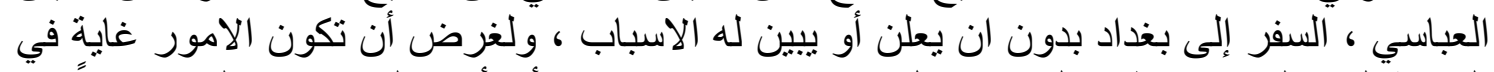

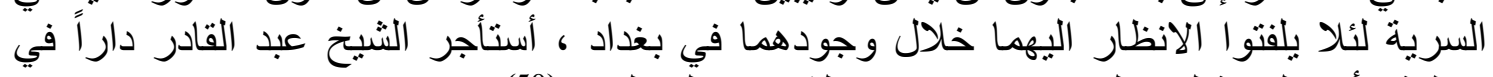

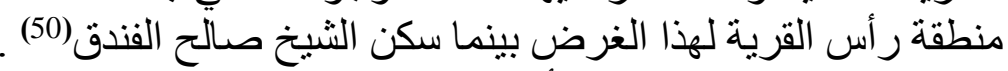

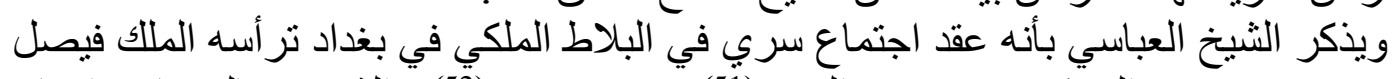

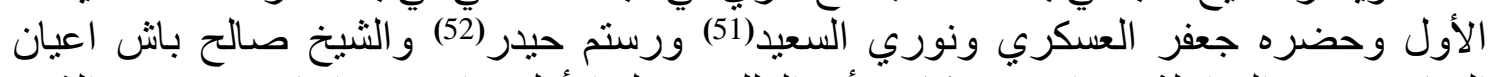

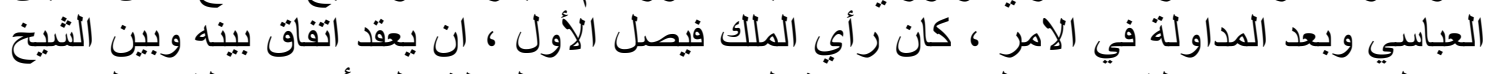

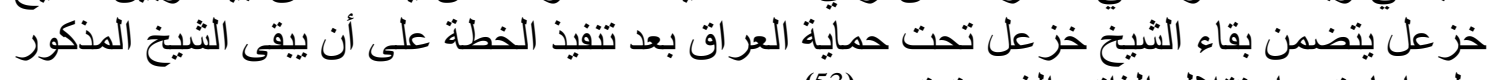
على امارته و استقلاله الذاتي الذي يتمتع به بـ (53) . 


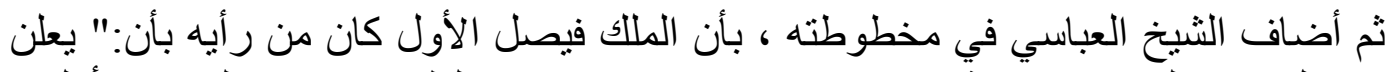

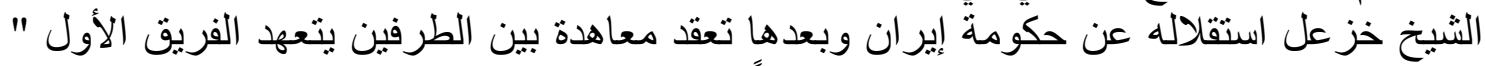

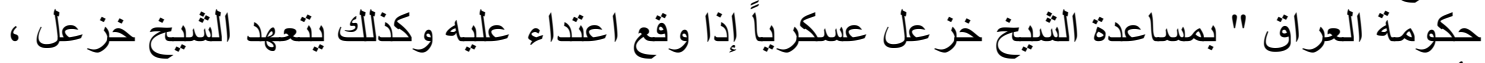

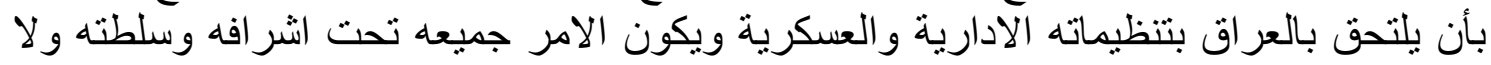

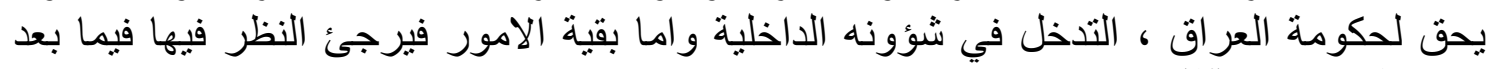

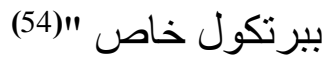

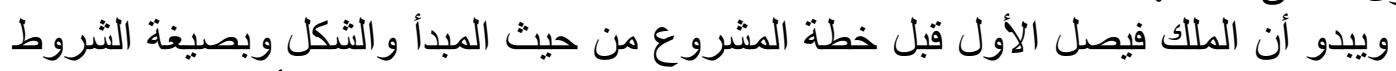

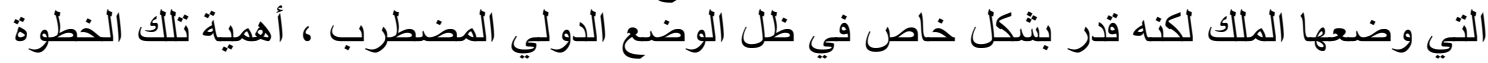

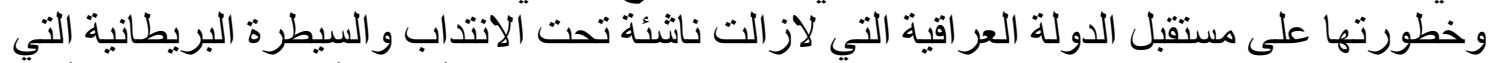

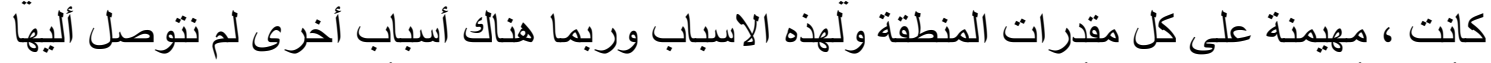

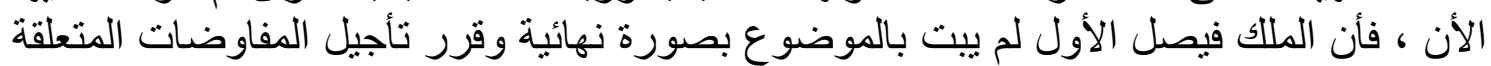

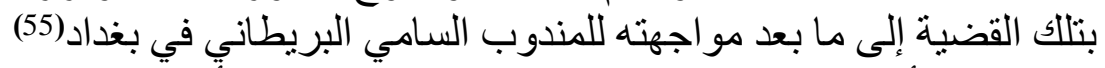

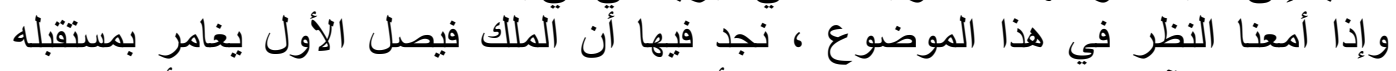

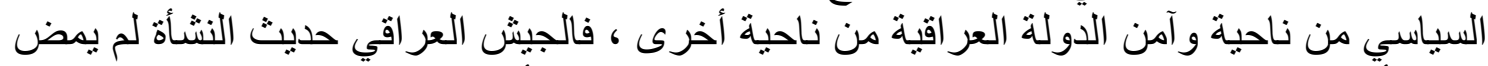

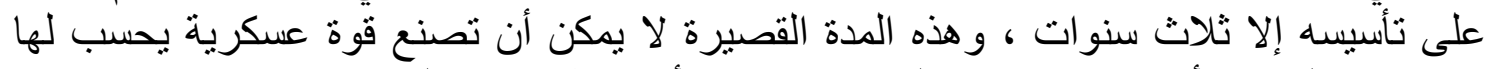

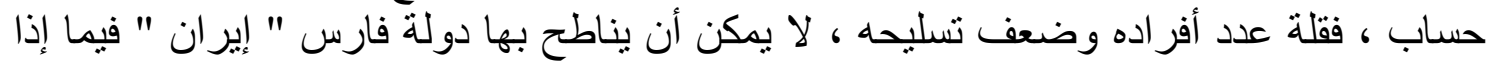

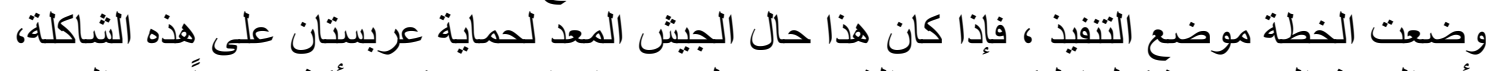

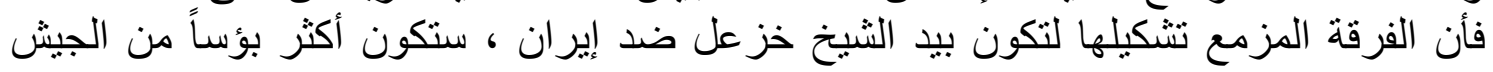

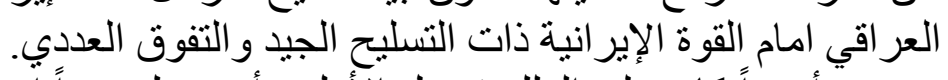

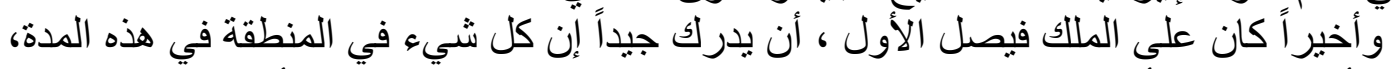

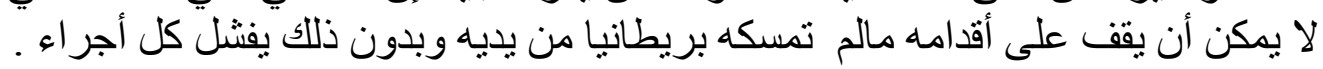

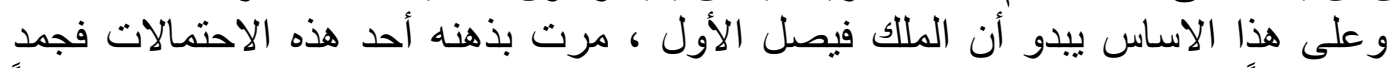

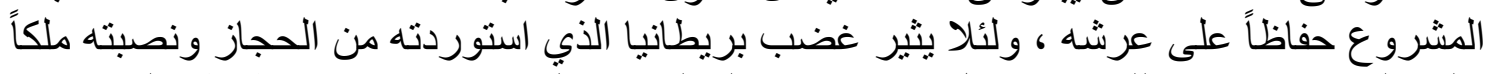

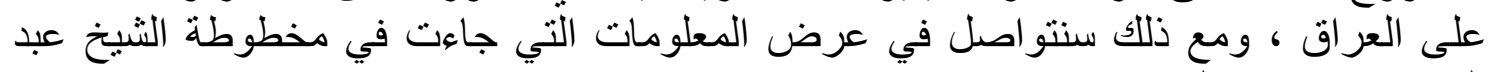

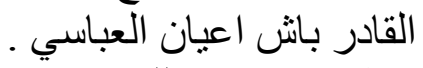
خطوات ممهدة للمشروع الفياني

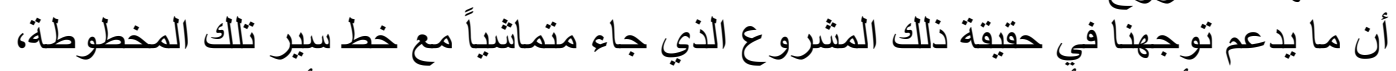

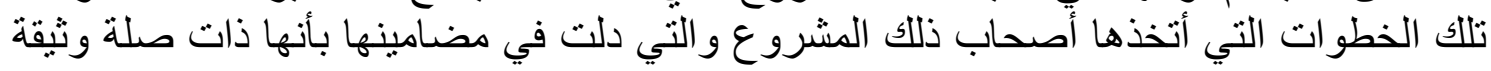

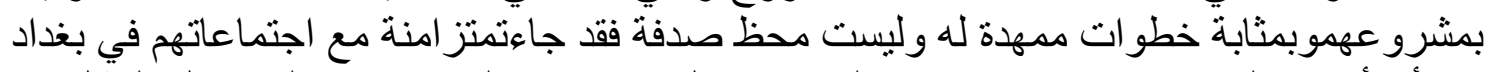

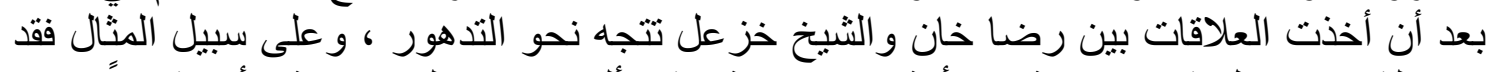

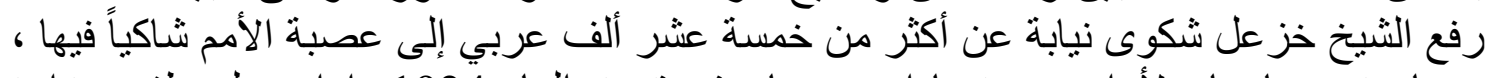

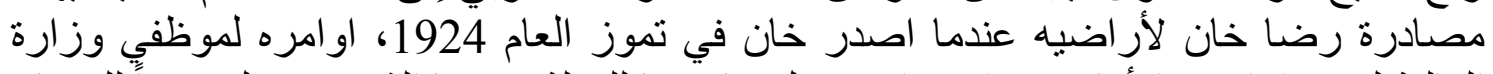

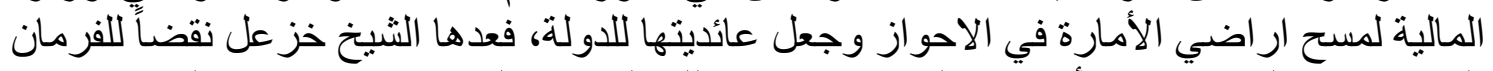

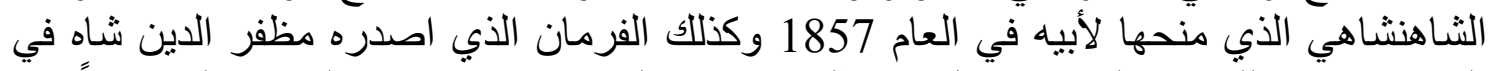

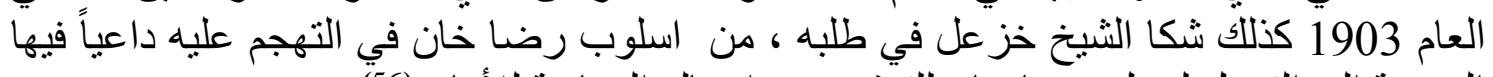

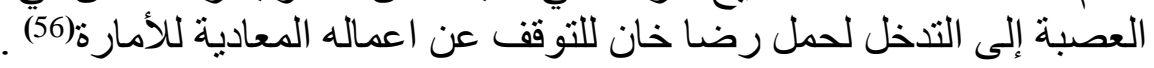




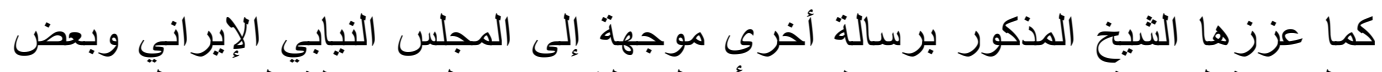

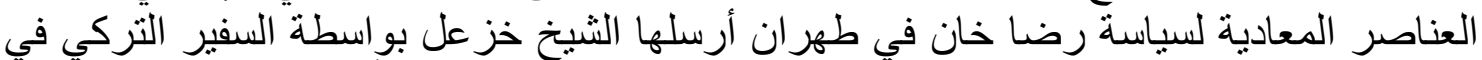

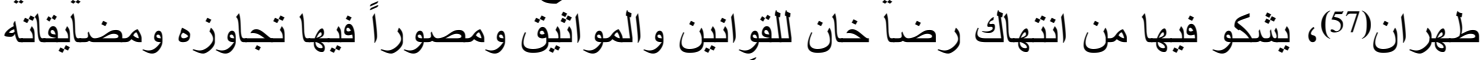

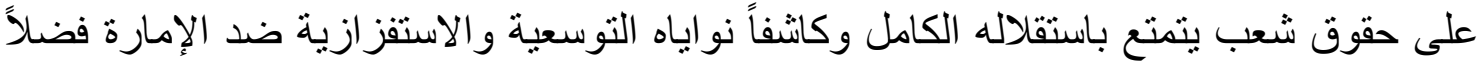

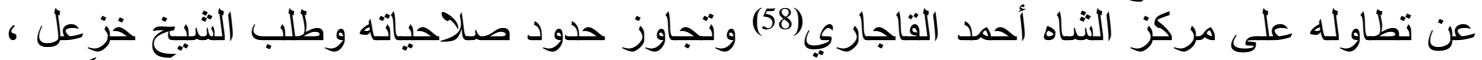

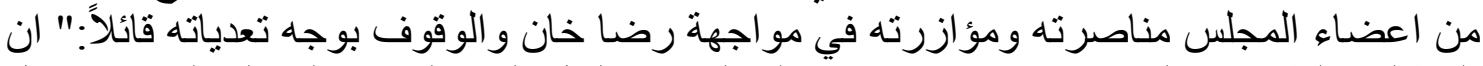

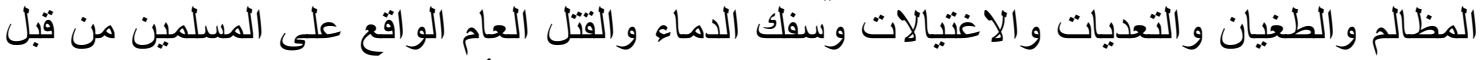

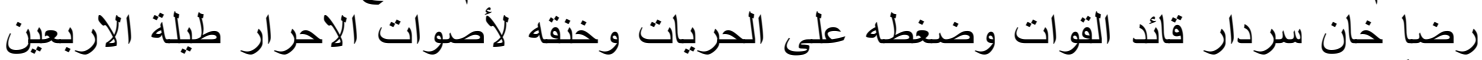

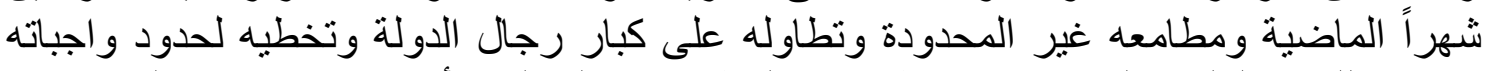

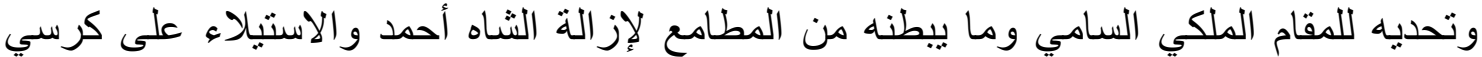

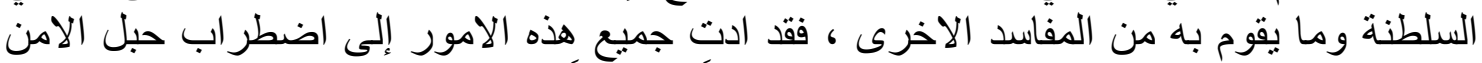

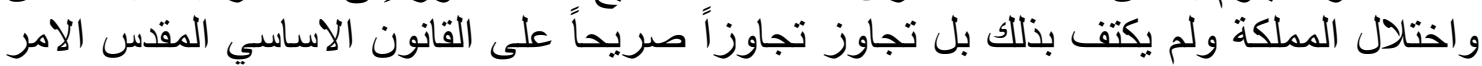

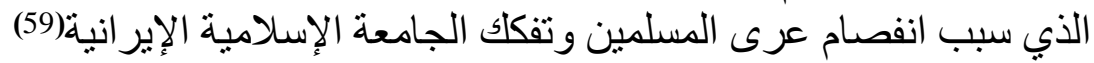

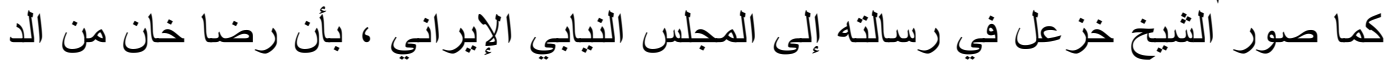

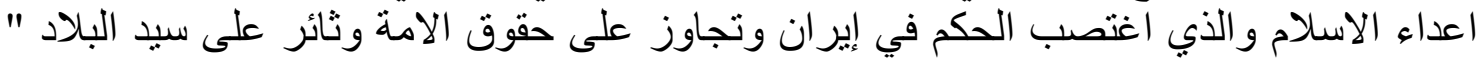

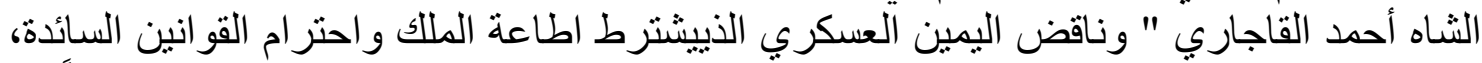

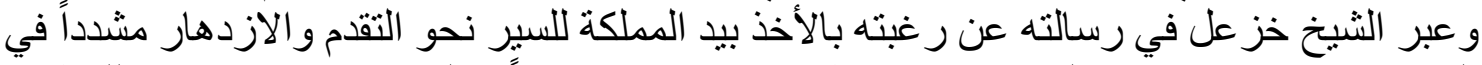

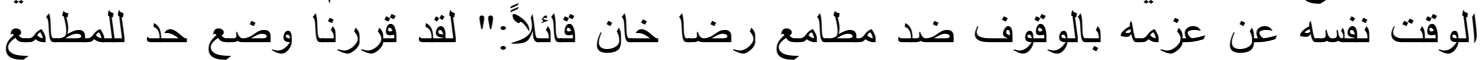

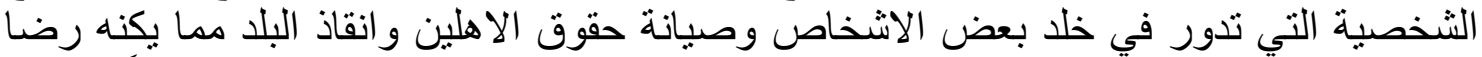

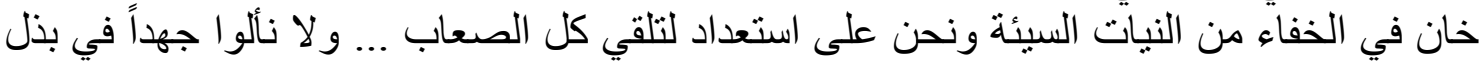

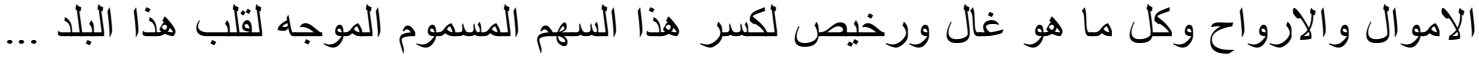

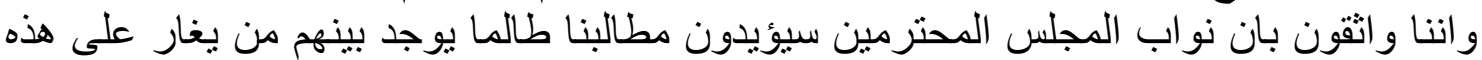

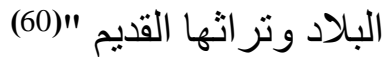

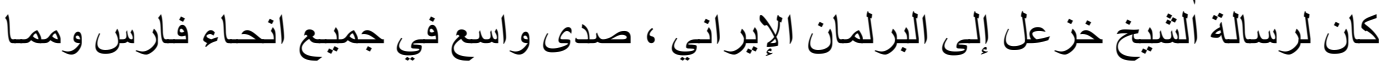

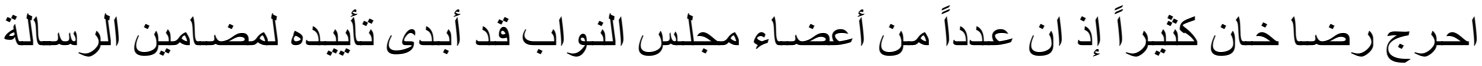

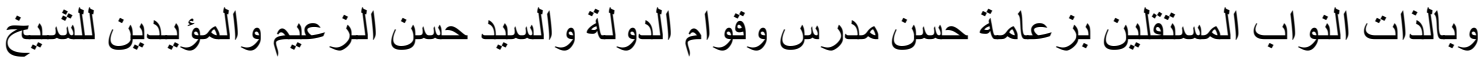

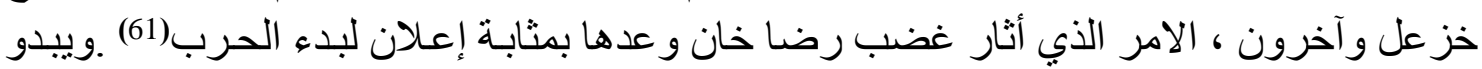

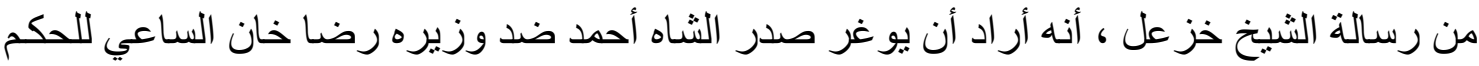

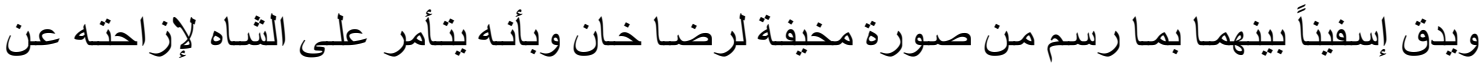

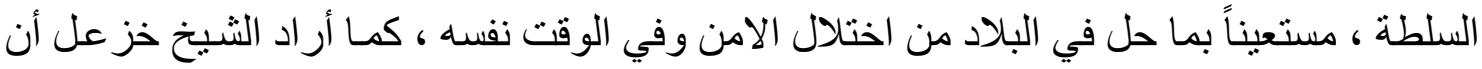

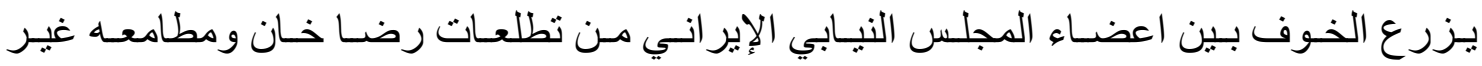
الدستورية ، و هي خطو ات تصب في تطلعات الثيخ خز عل ومشرو عهاء سالف الذكر.

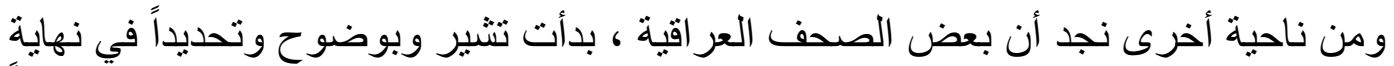

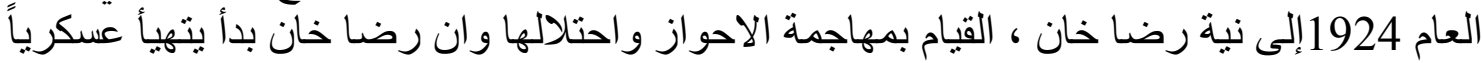


لعمله هذا حيث قام بأرسال حو الي 60 جندياً إلى مدينة تستر وظلاوا هناك بحجة ضرب العناصر المعادية له (62) . وفي خطوة ذكية وشجاعة تبدو أنها كانت استباقية ، توجه الشيخ خز عل هذه المرة صوب

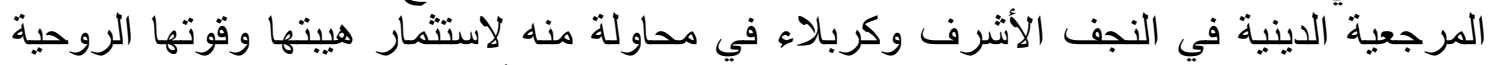

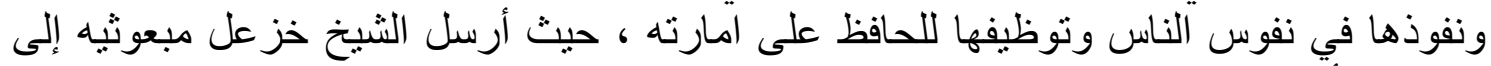

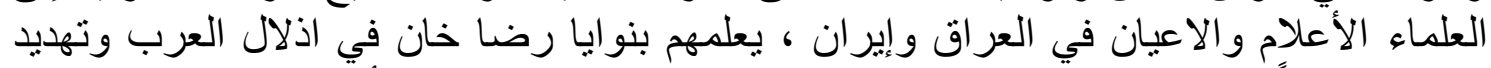

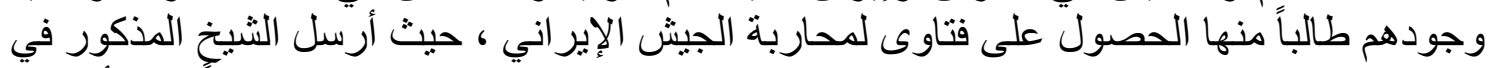

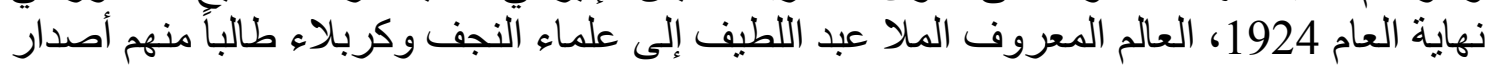
الفتاوي الدينية اللازمة والتي التي التر ع محاربة الجيش الفارسي " الإير اني "(63).

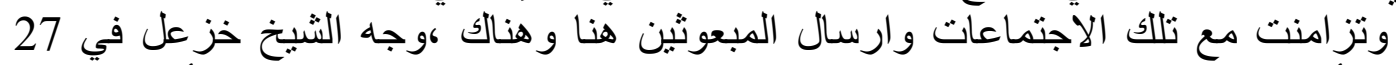

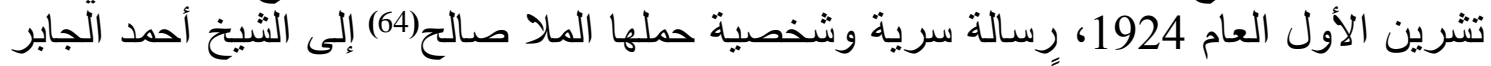

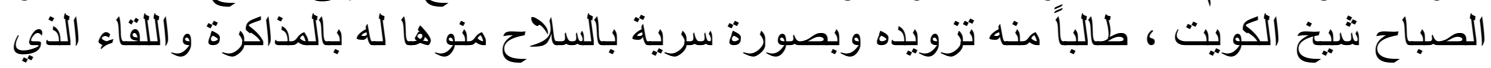

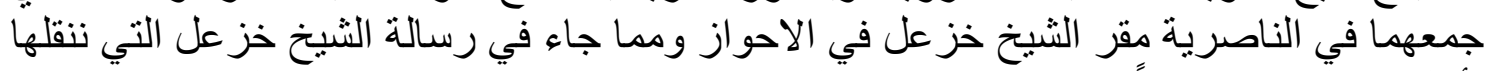

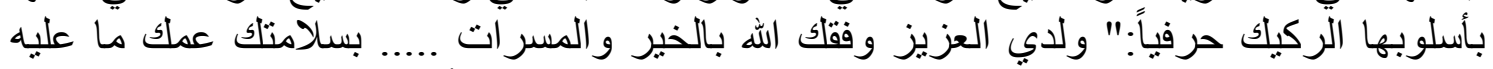

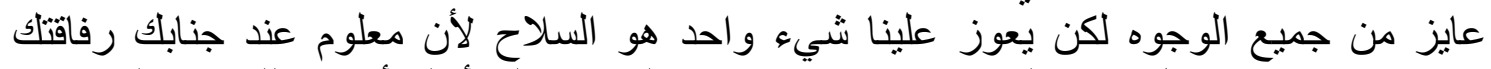

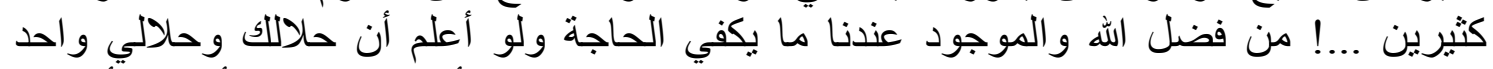

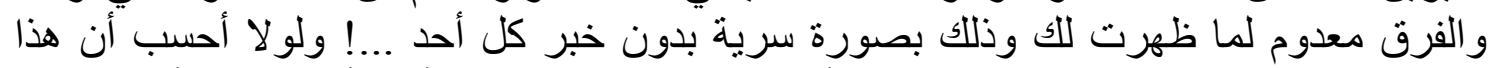

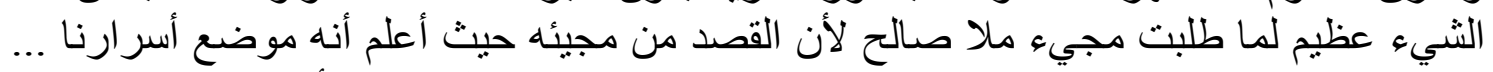

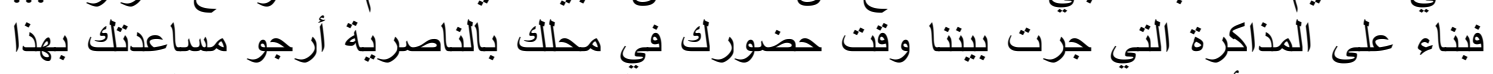

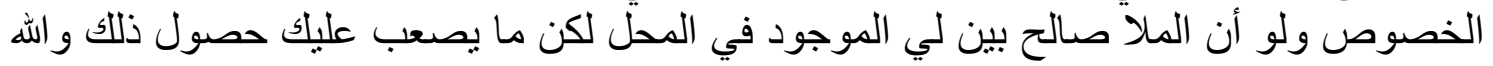

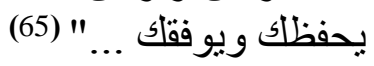

كما عزز الشيخ خزعل رسالته انفة الذكر برسالة أخرى إلى الثيخ الصباح بهذا الثأن و هذا

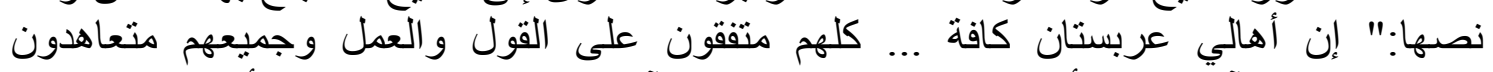

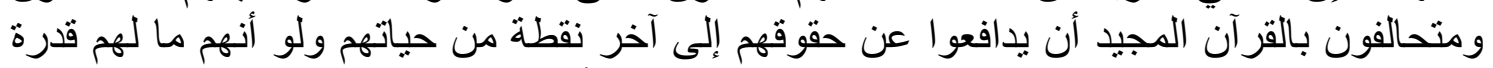

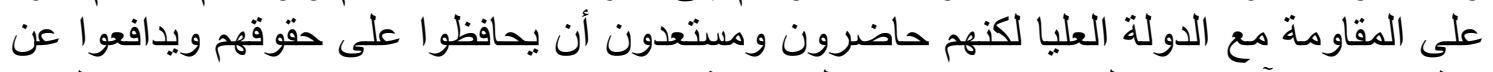

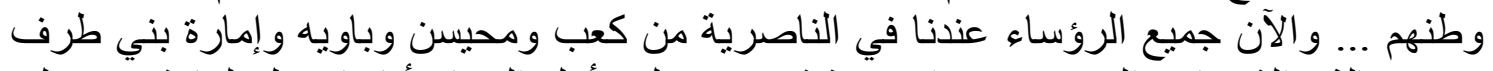

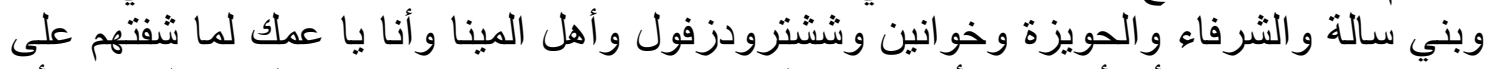

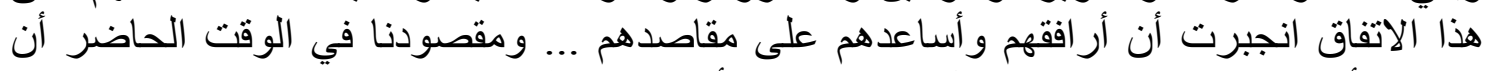

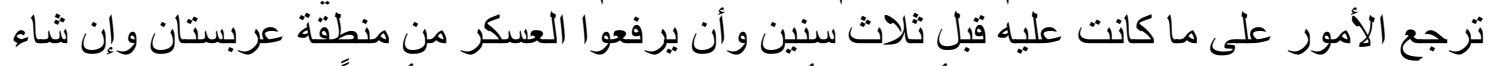

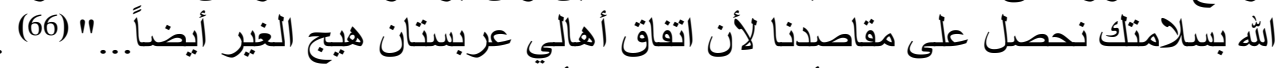

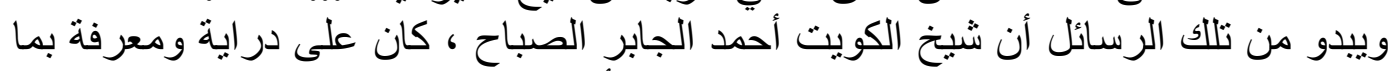

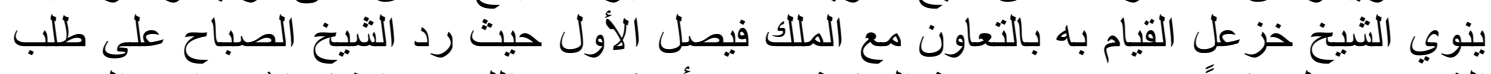

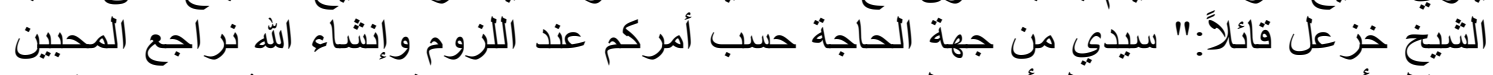

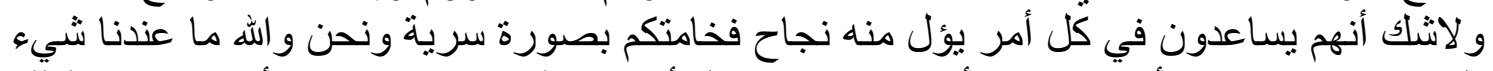

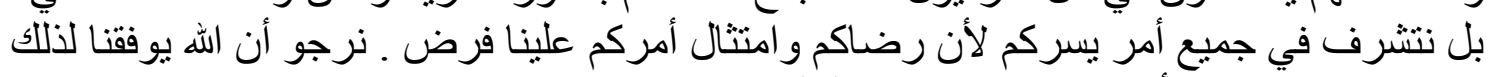

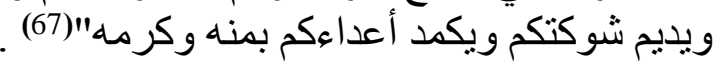




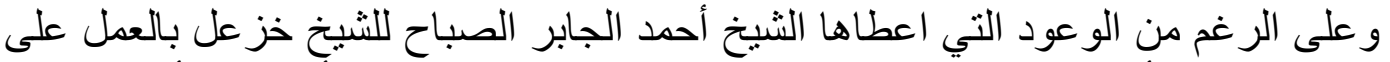

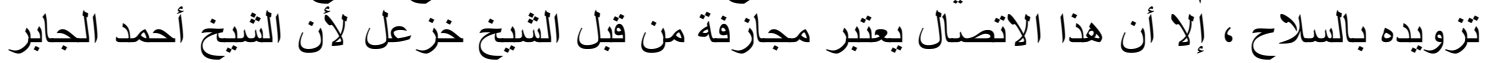

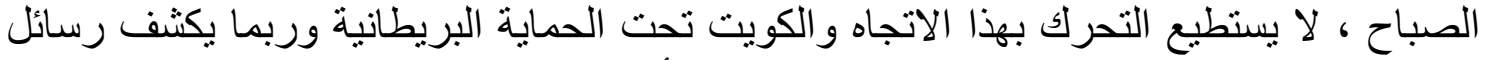

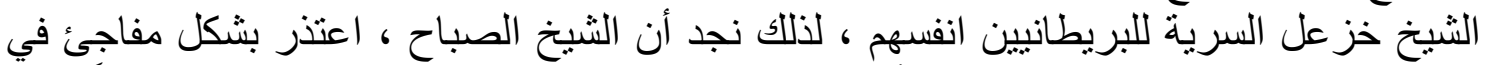

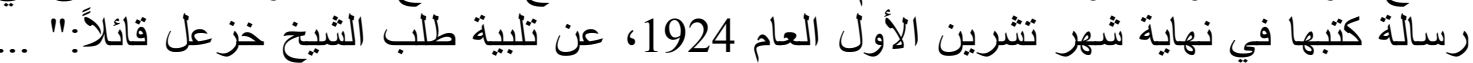

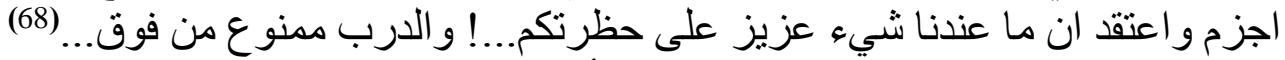

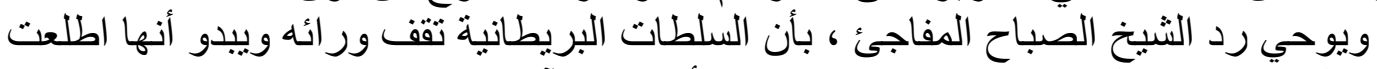

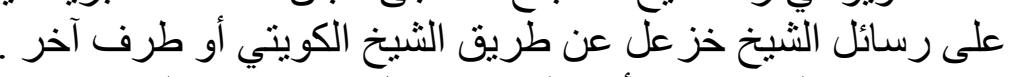

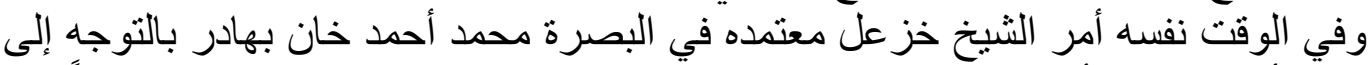

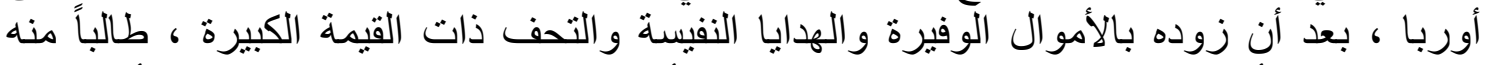

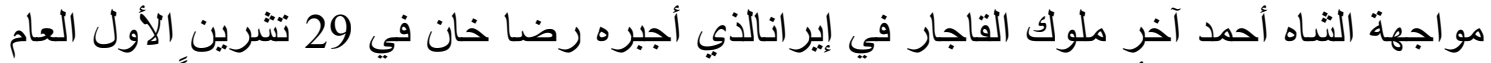

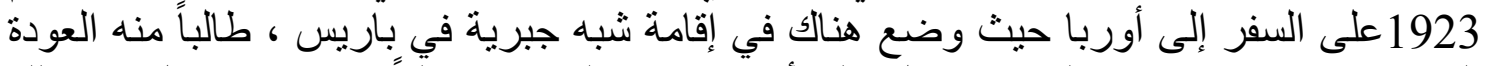

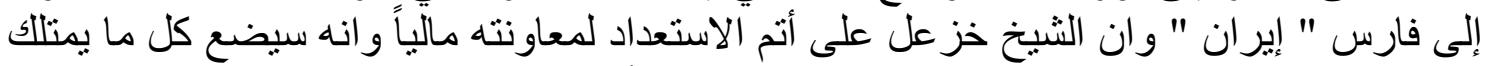

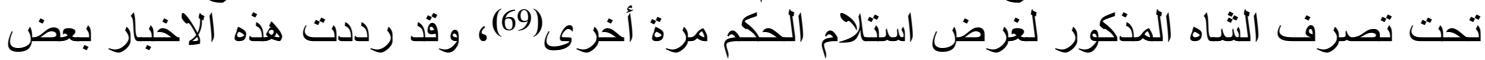

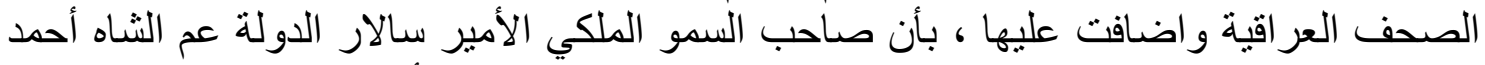

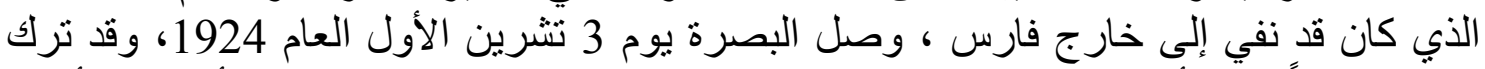

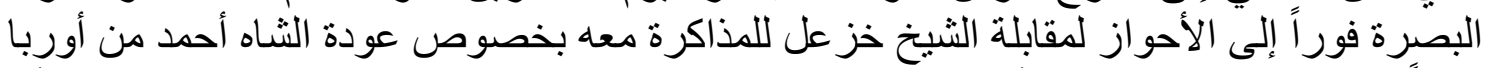

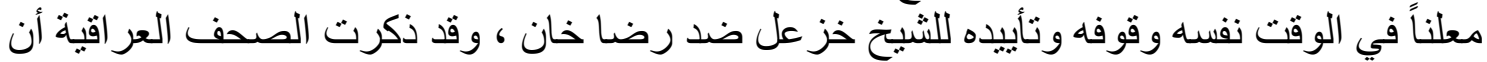

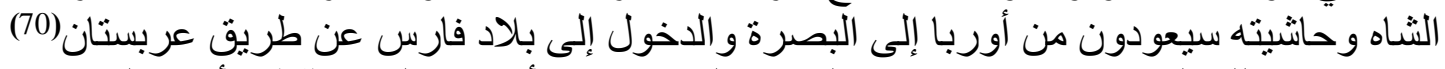

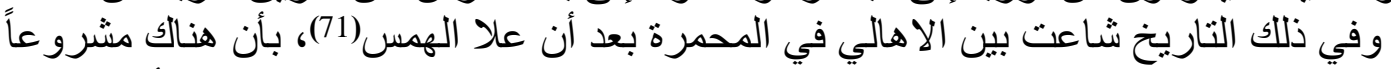

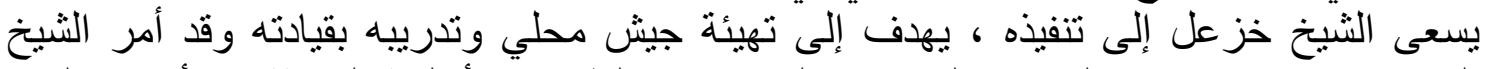

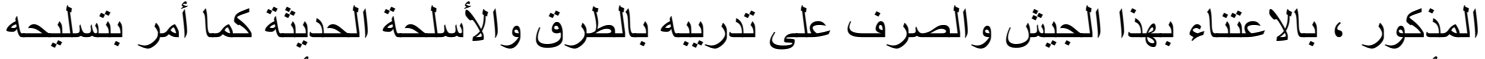

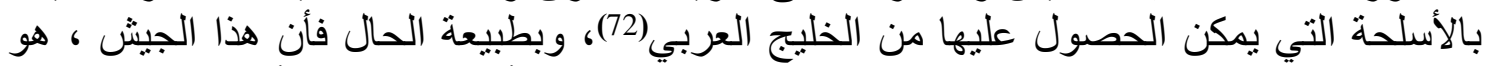

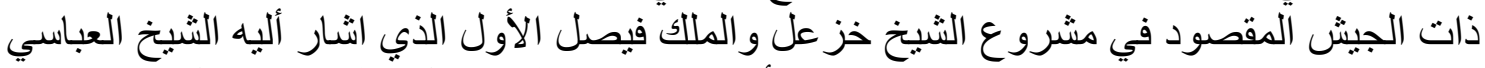

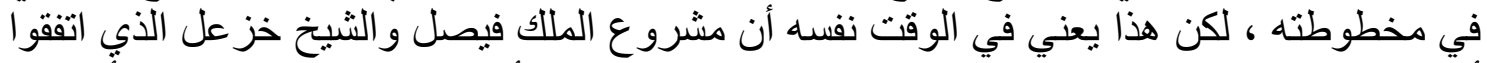

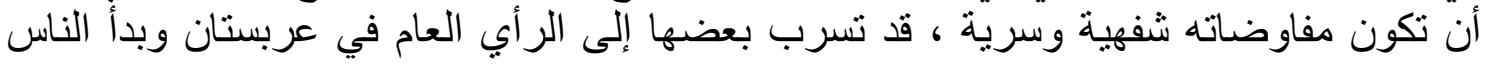

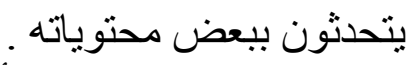

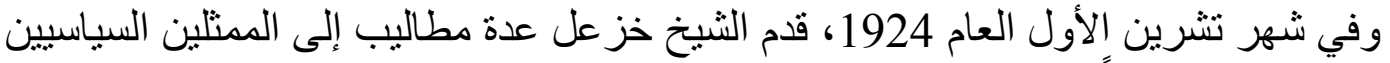

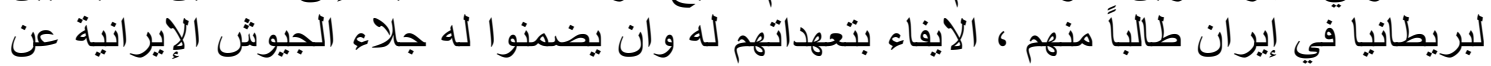

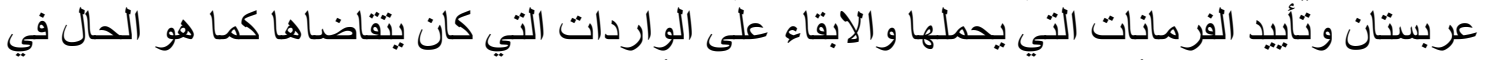

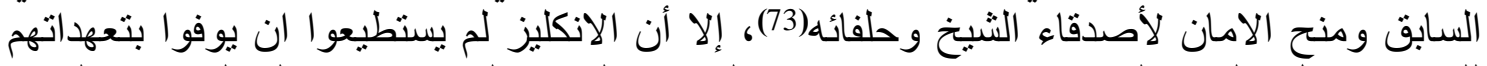

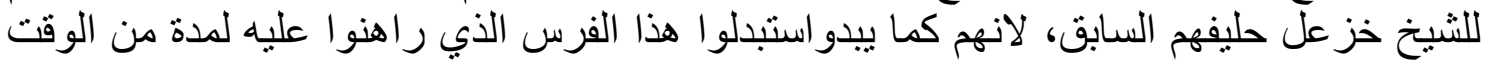

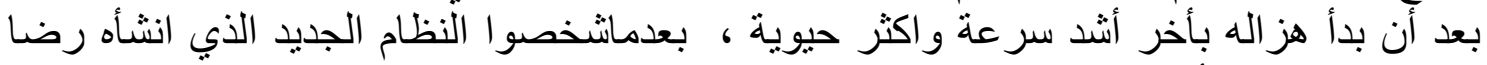

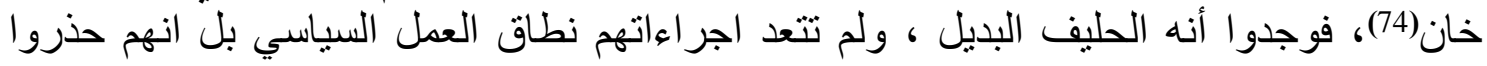

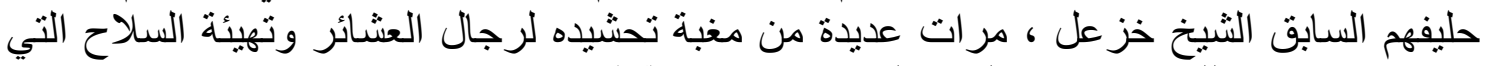

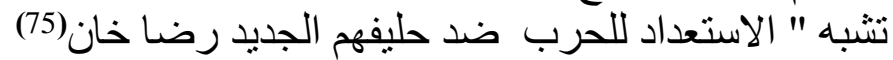




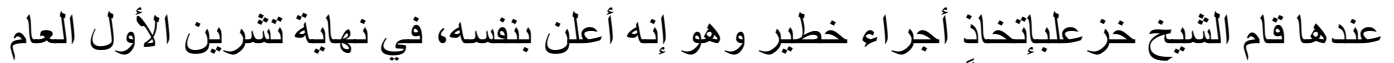

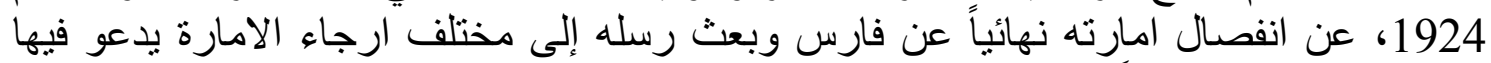

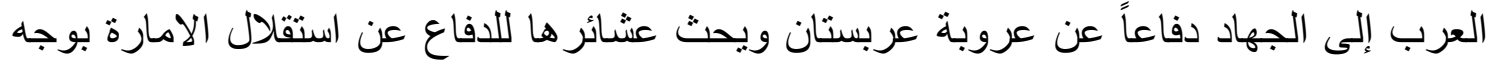

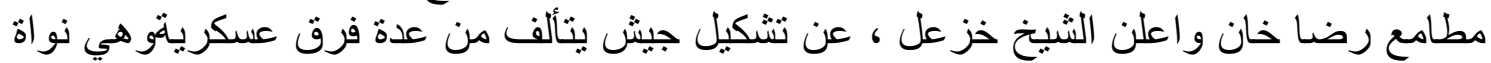

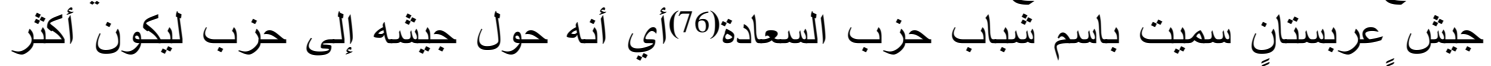

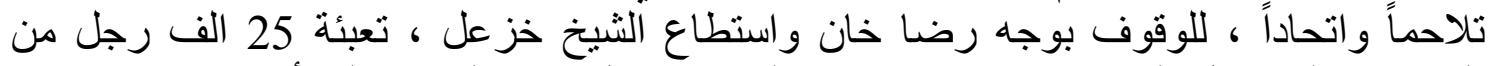

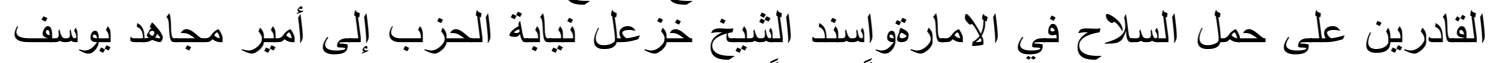

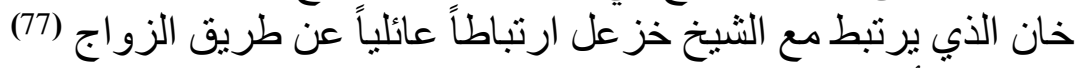

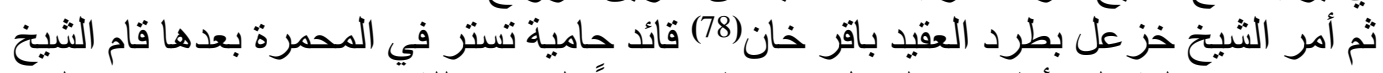

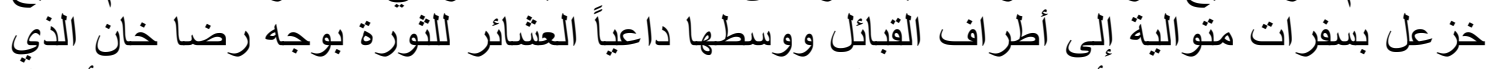

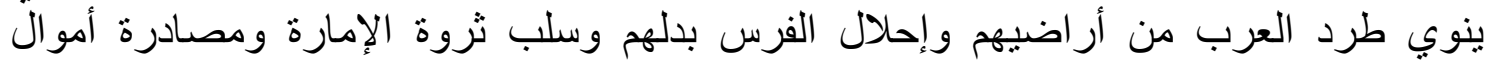

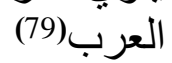

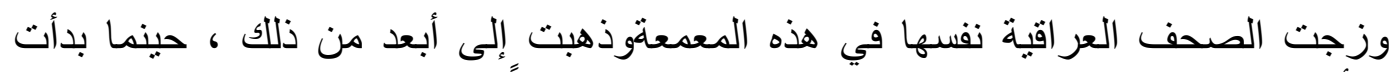

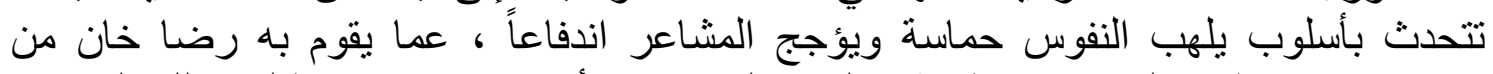

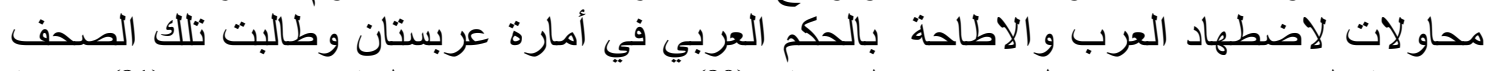

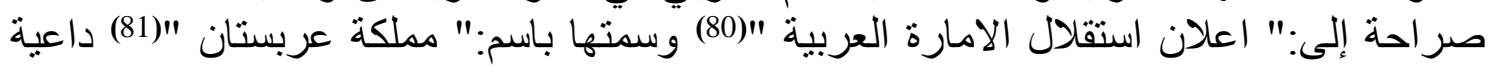
إلى انفصالها عن إيران لتباين نوعية السكان واختلاف العناف العنصر والحاق هذه الامارة بالأمارات داتية

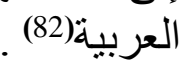

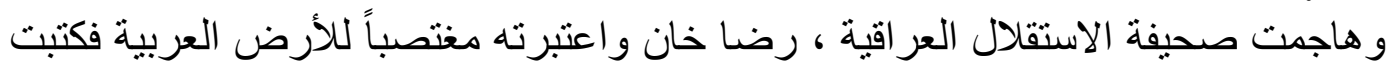

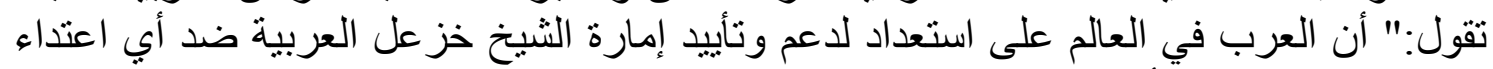

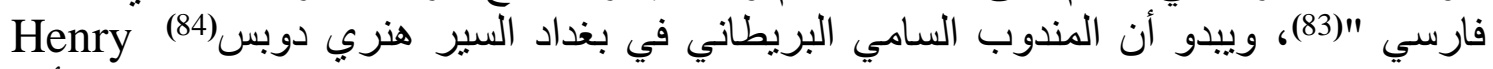

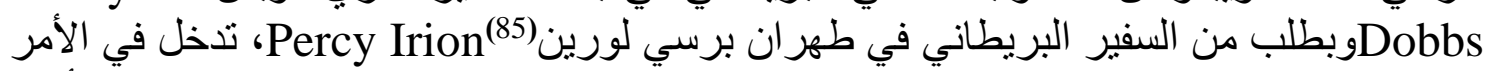

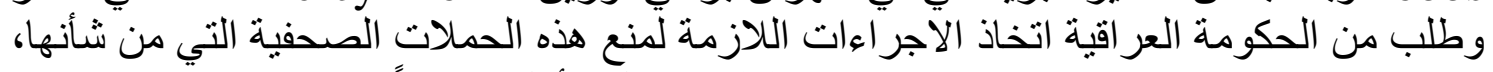

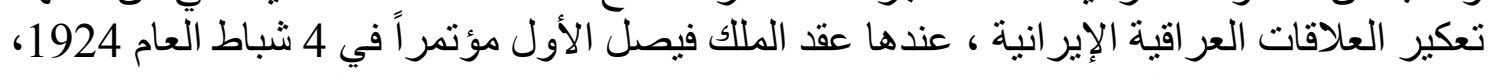

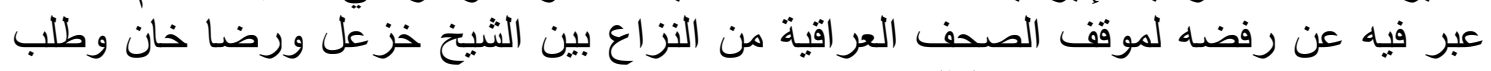
الملك من الصحف ايقاف حملاتهم (86) .

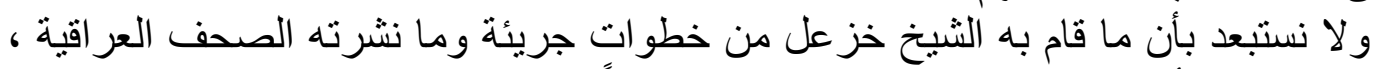

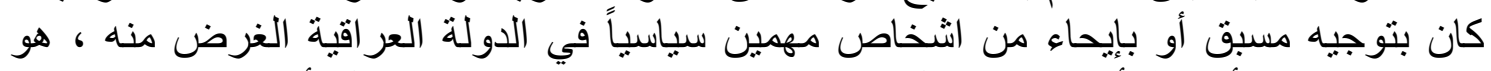

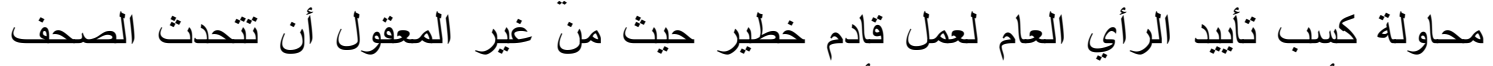

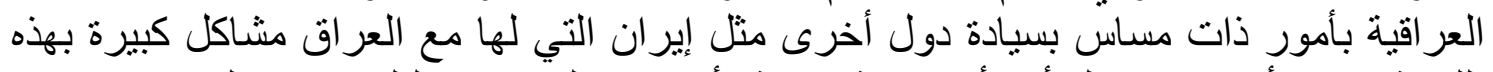

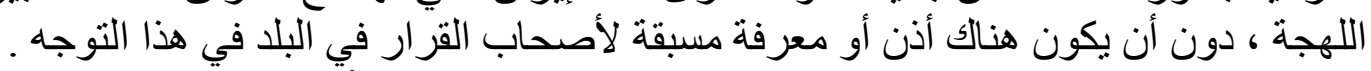

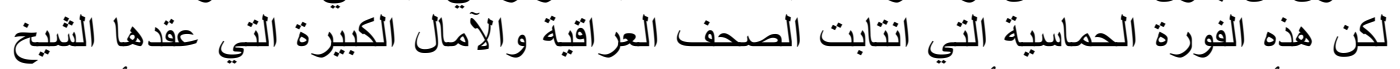

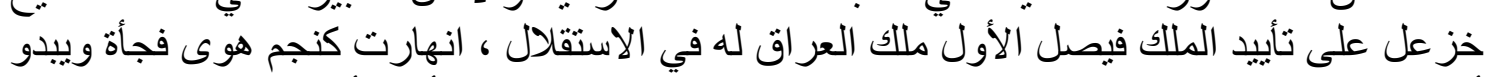

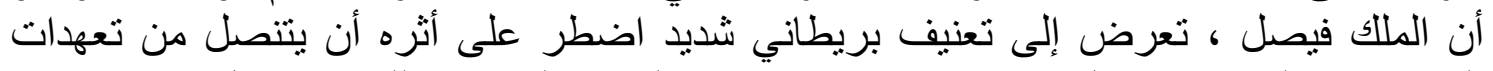

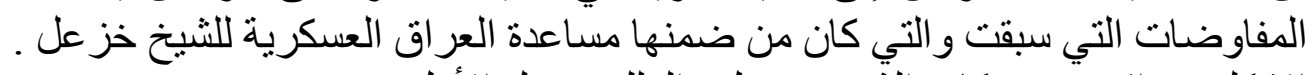
الانكليز ير اقبون تحركات الثيخ خز عل و الملك فيصل الأول 


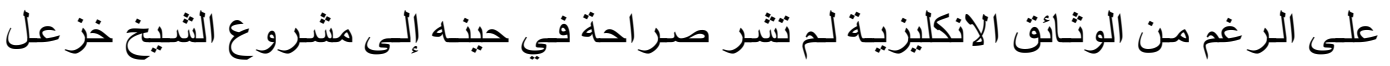

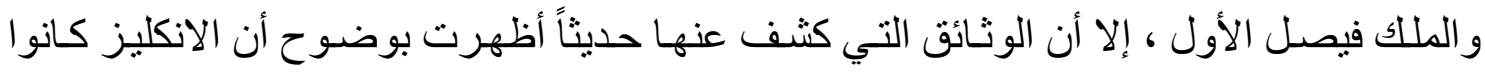

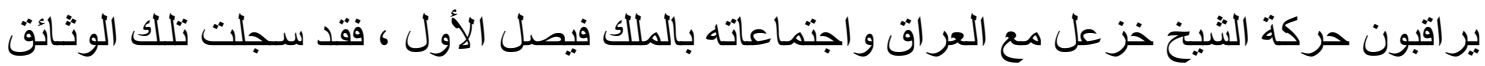

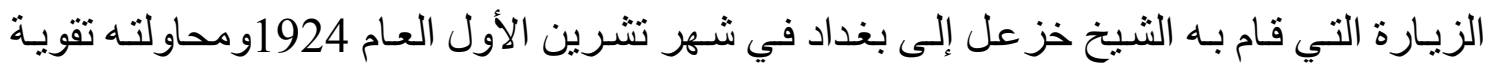

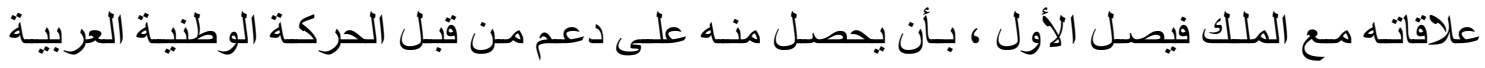

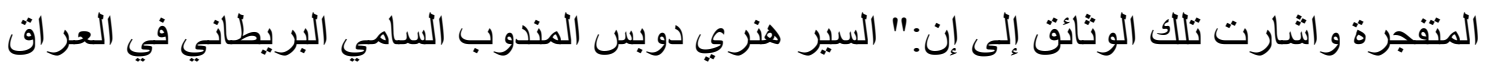
نظر إلى الثيخ خز عل وكأنه شخص مثنير للمتاعب أكثر من كونه حليفاً لهم "(87)

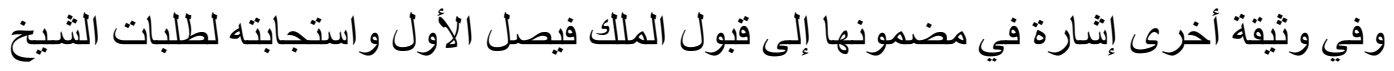

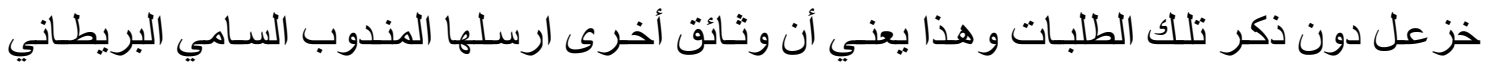

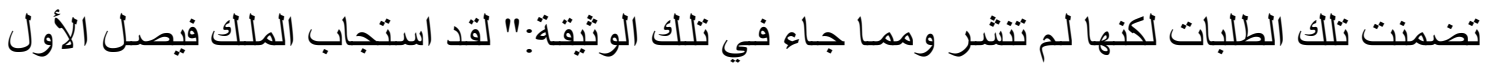

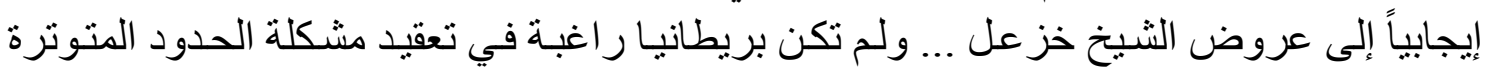

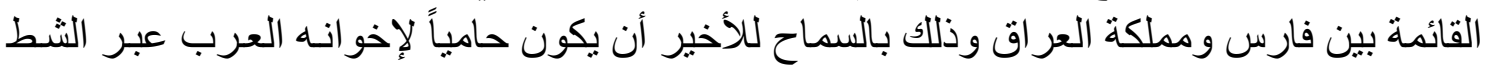

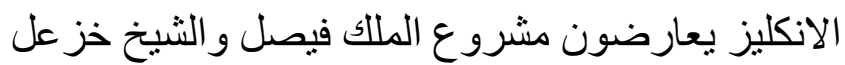

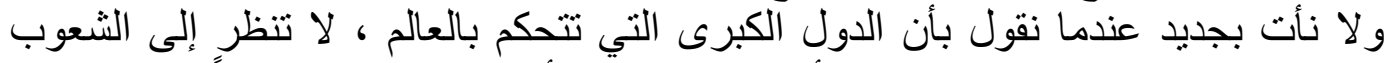

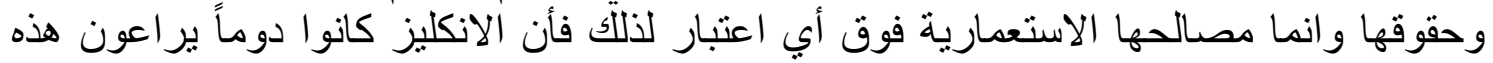

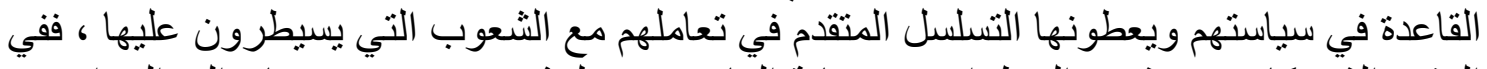

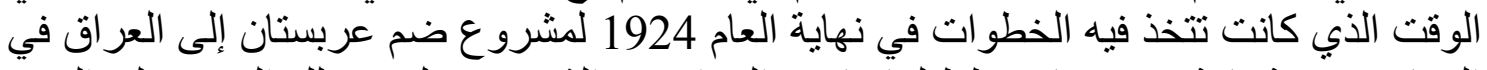

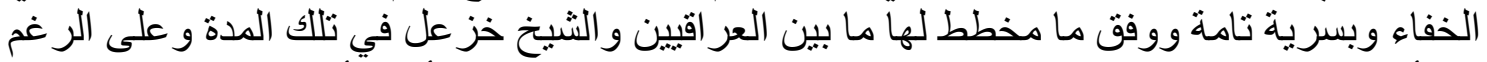

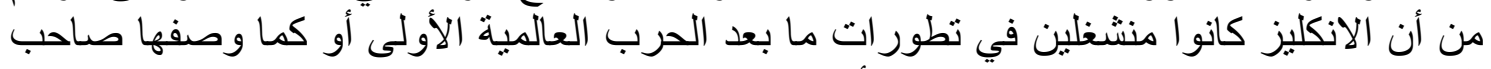

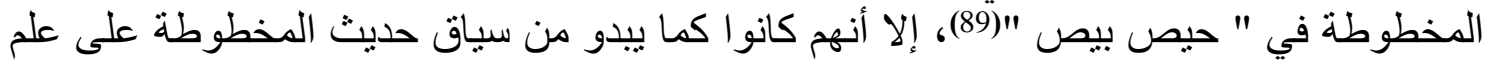

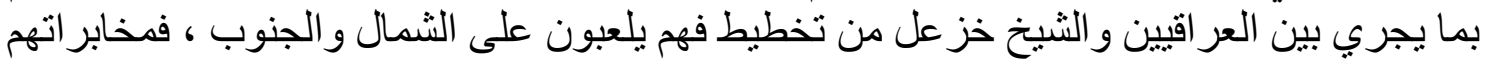

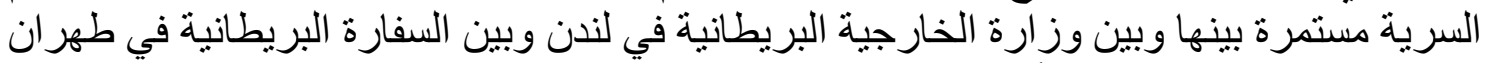

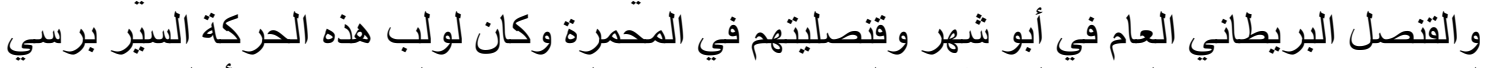

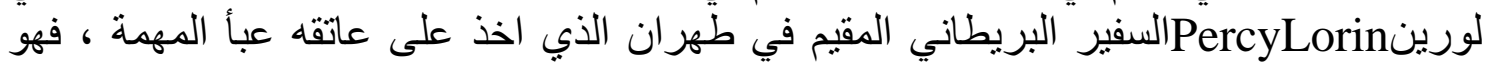

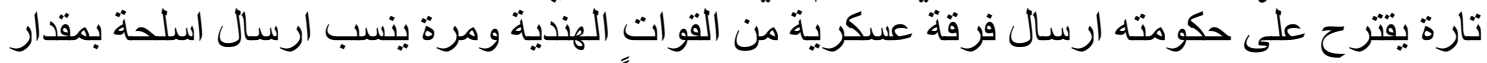

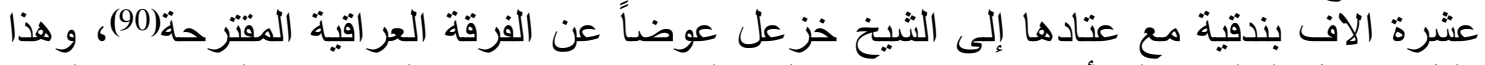

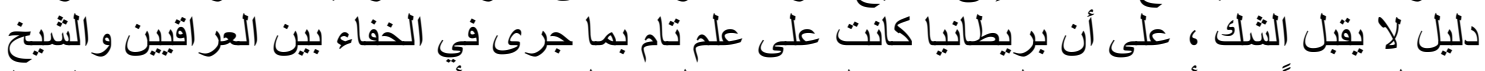

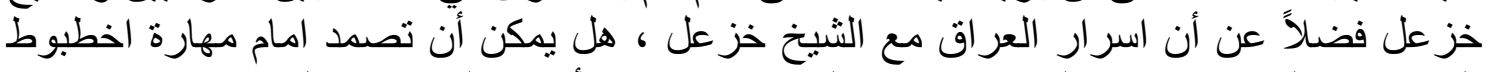

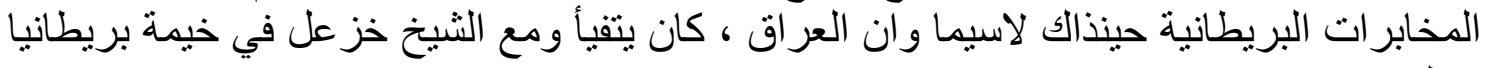
وبهذا الصدد ذكر الثيخ عبد القادر باش اعيان العباسي في مخطوطته بان السفير البريطاني

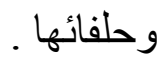

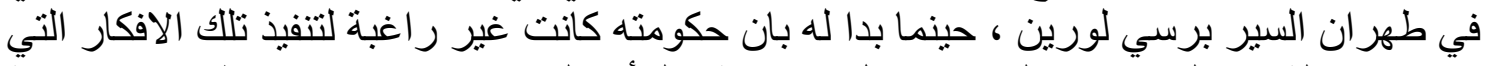

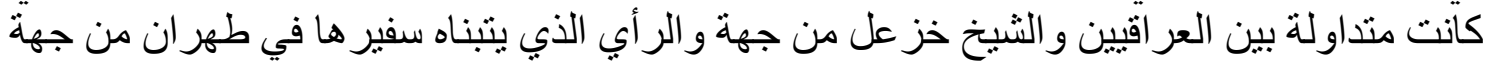


ثانية ، بسبب ما تعانيه حكومة بريطانيا من العجز المالي الكبير في خزينتها بعد أن انهتها الديون

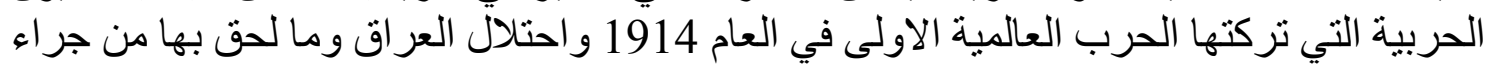

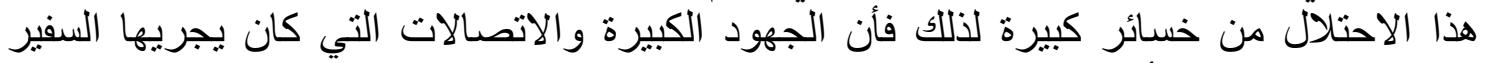

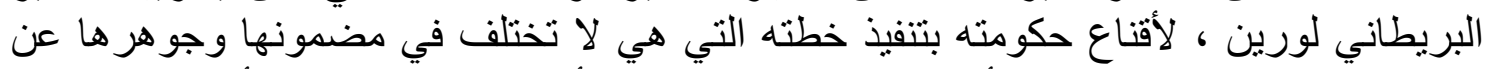

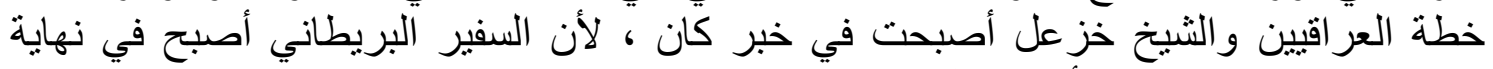

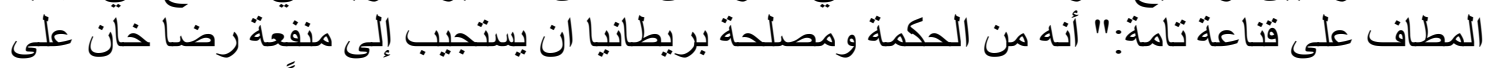

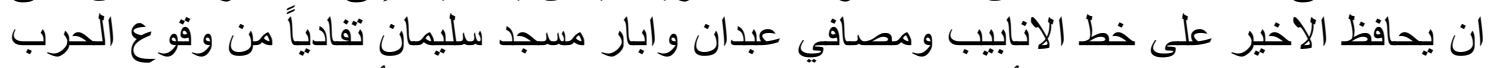

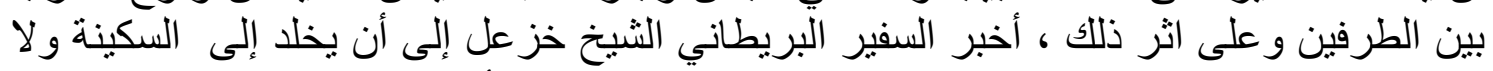

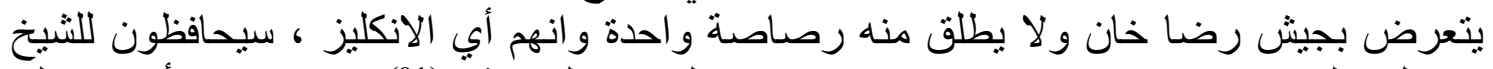

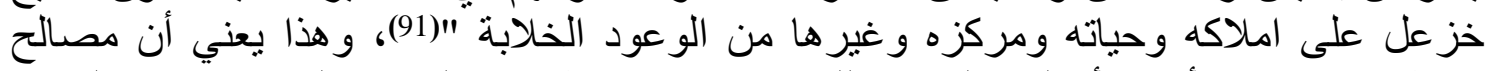

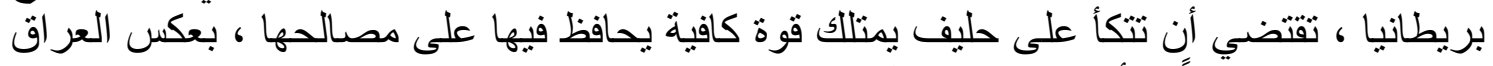

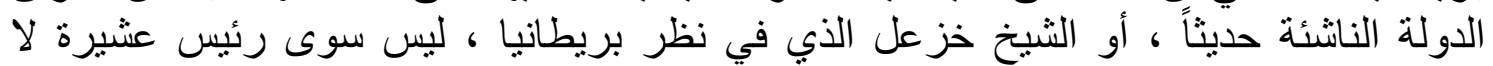

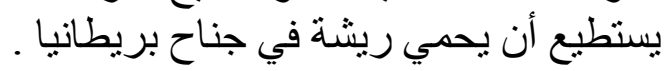

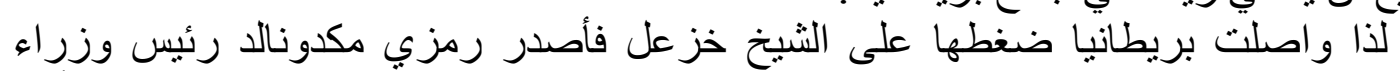

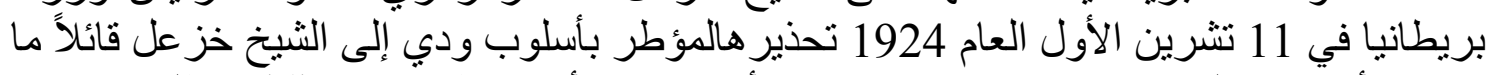

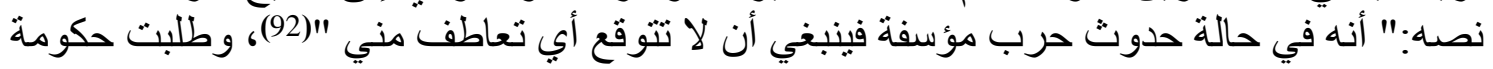

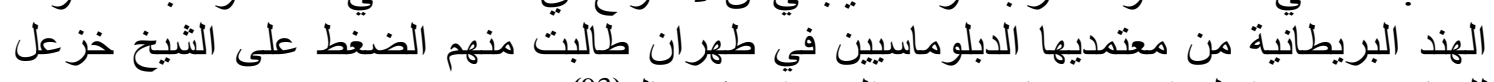

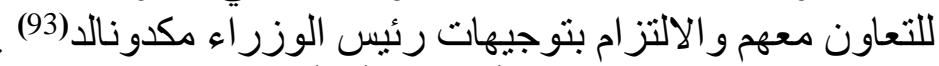

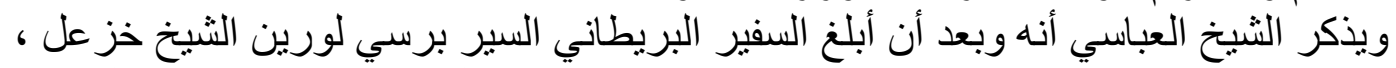

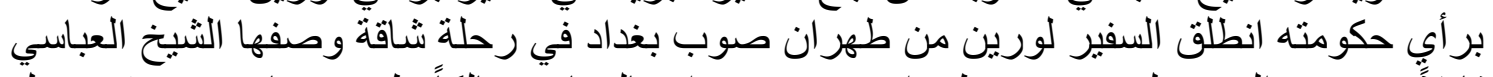

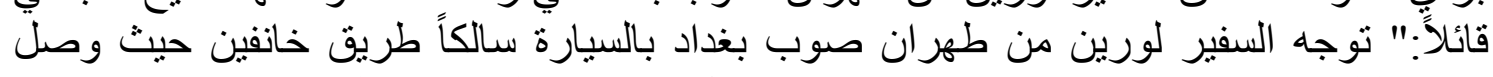

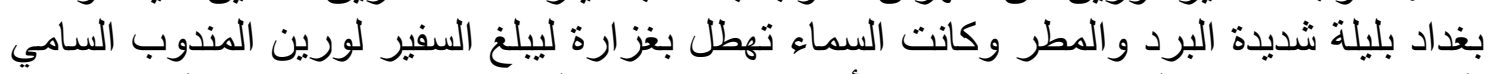

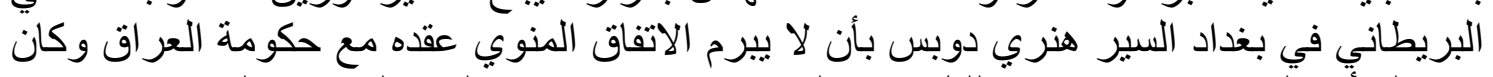

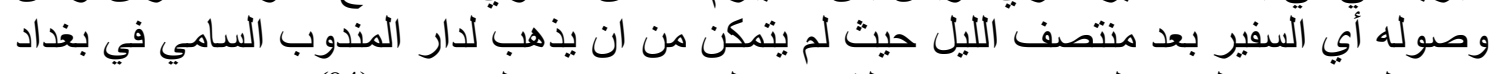

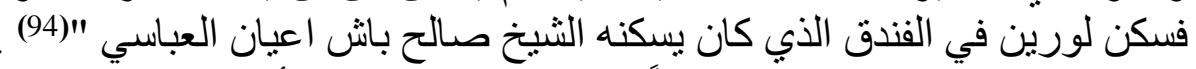

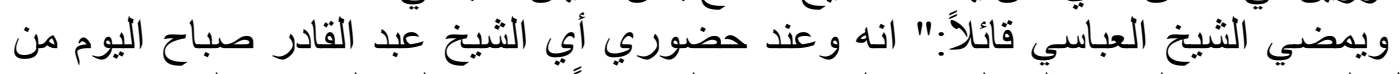

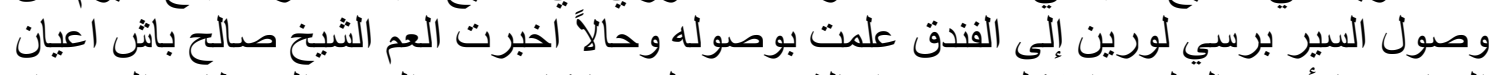

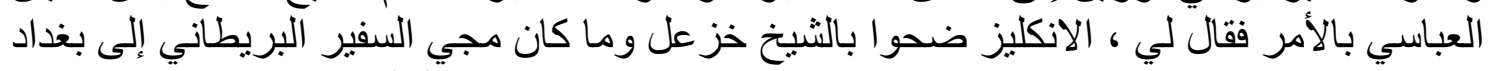

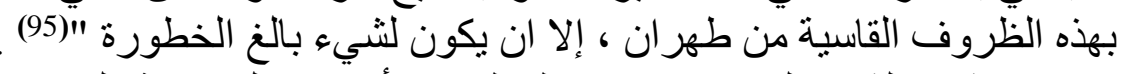

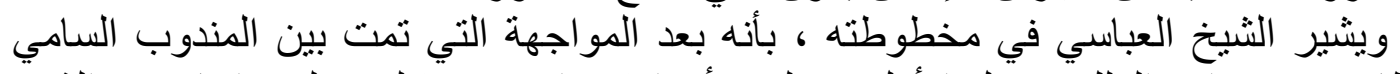

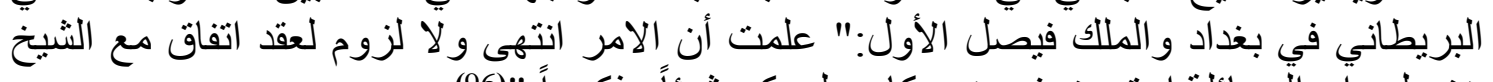

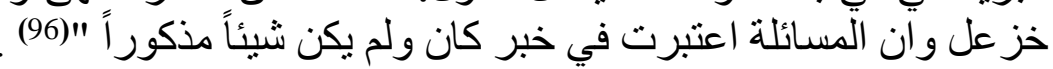

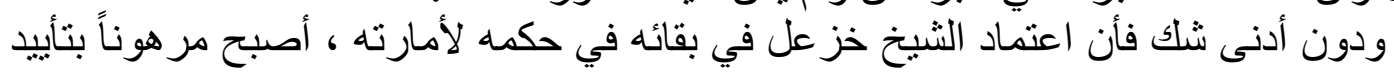

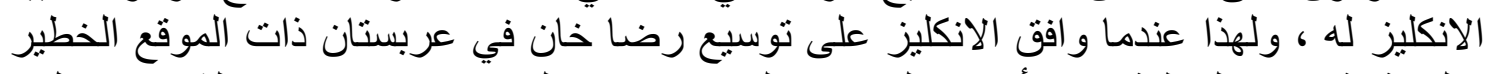

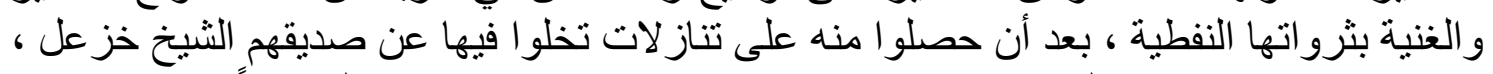

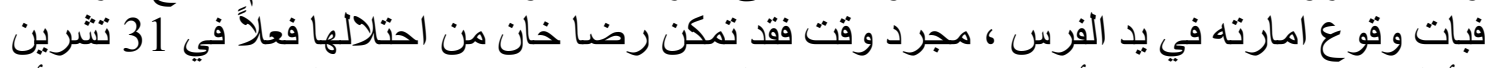

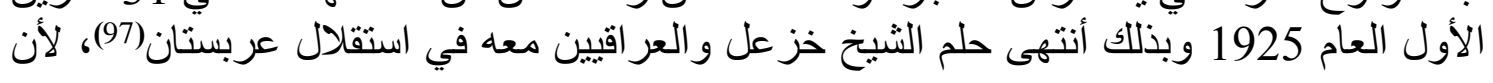


بريطانيا ار ادت ذلك لأنها القوة الوحيدة في تللك المنطقة وفي تللك المدة ، هي التي تتحكم برسم

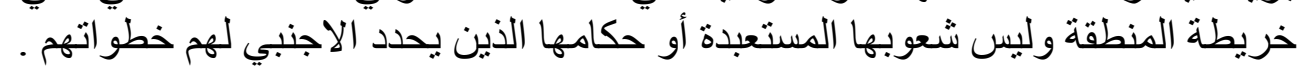

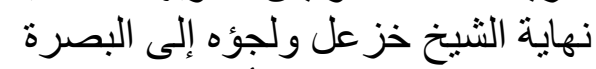

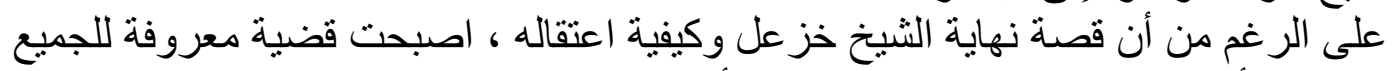

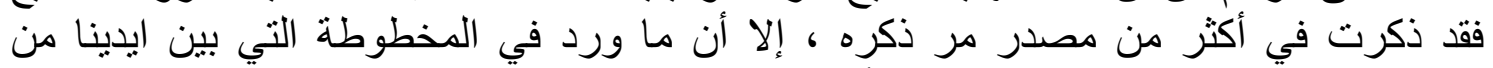

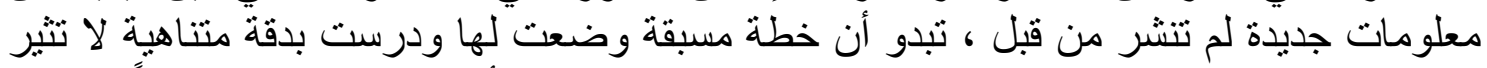
الريبة في سبيل اجهاض ، مشروع الثيخ خز عل و الملك فيصل الأول سالف فئل الذكر و اتمامـاً للفائدة ،

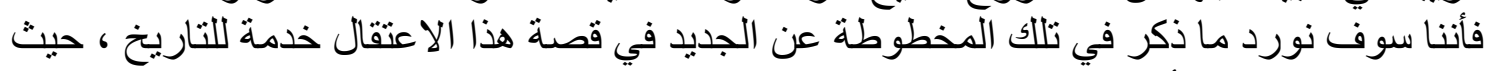

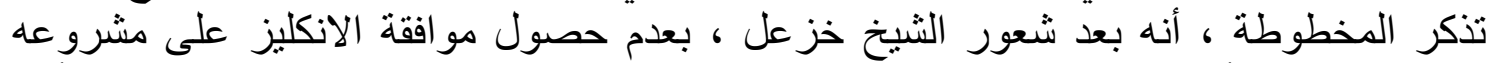

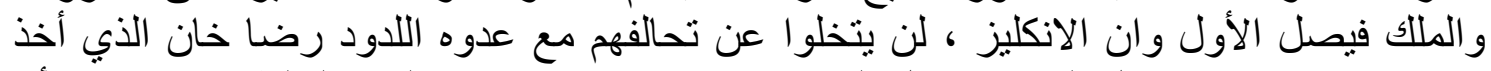

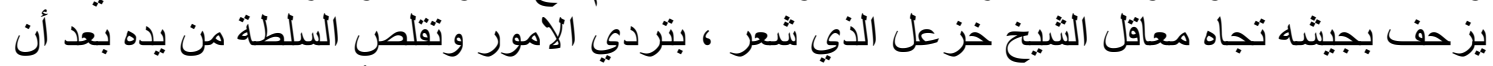

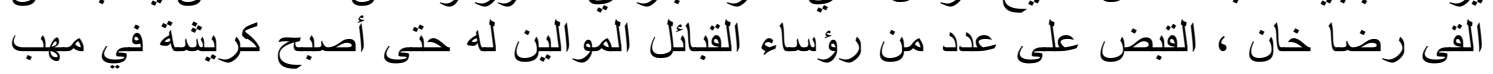

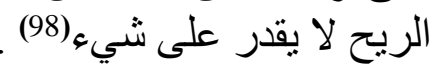
وتحت زحمة هذه الاوضـاع المتردية وقلة الانصار والمؤيدين والخطر المحدق به(99)، غادر

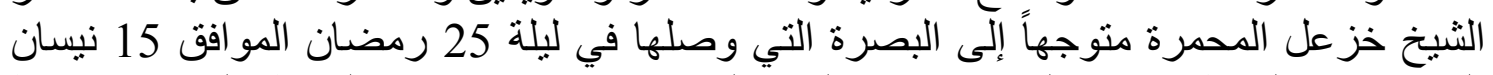

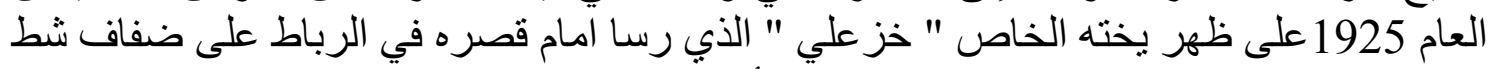

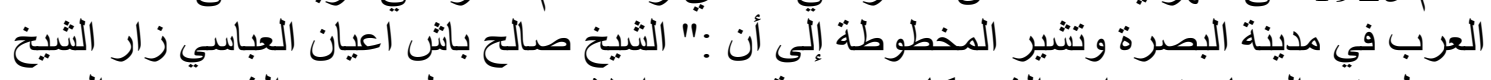

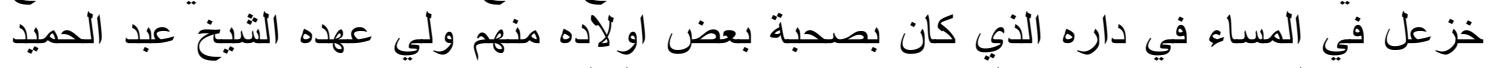

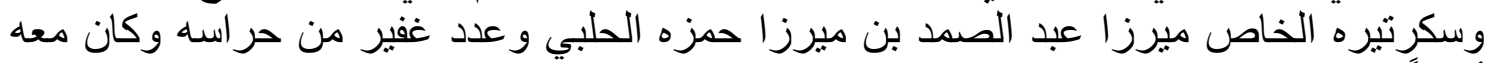

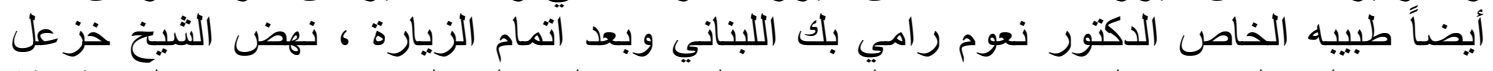

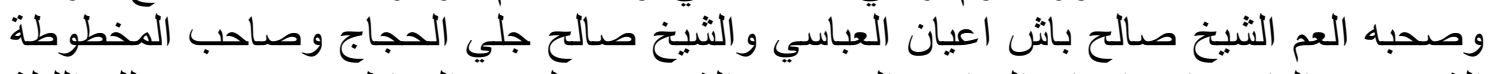

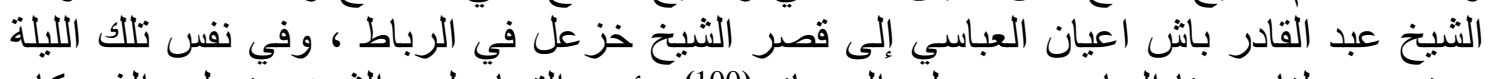

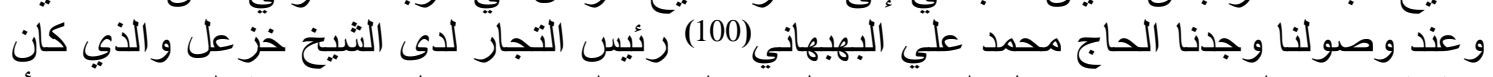

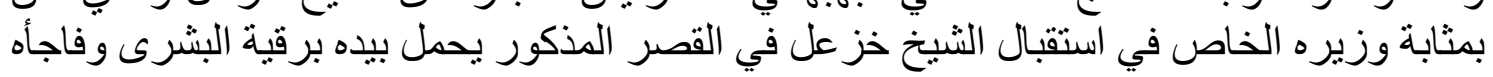

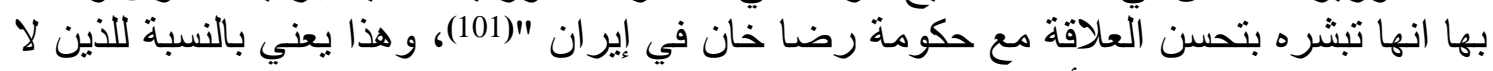

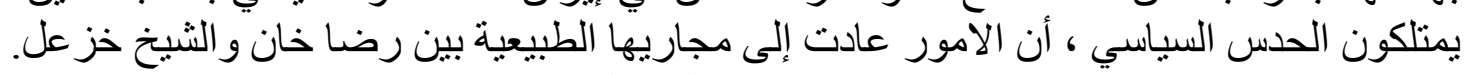

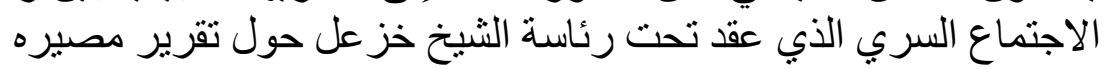

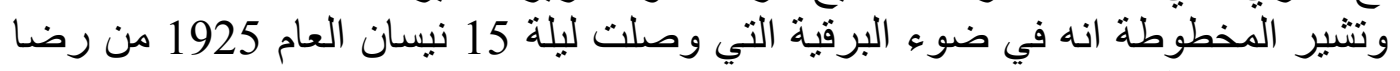

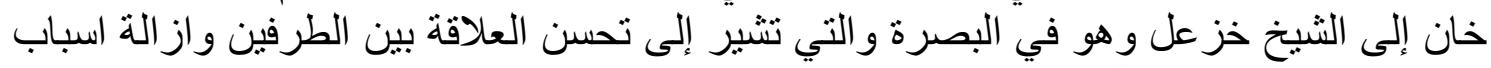

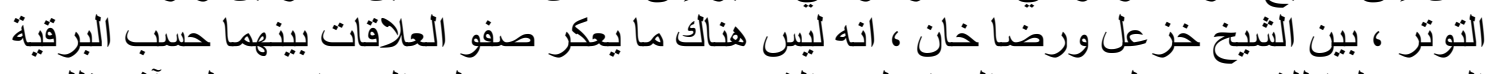

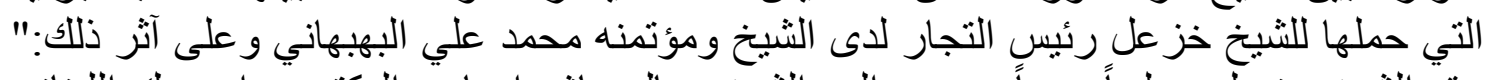

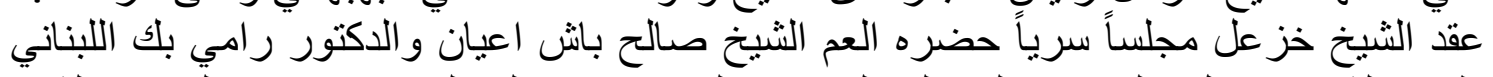

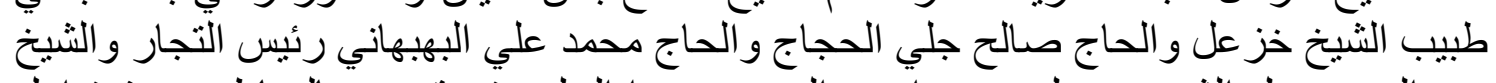

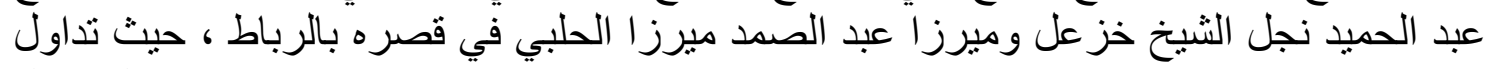

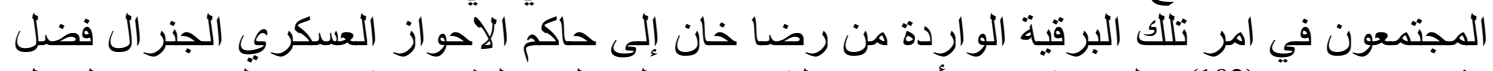

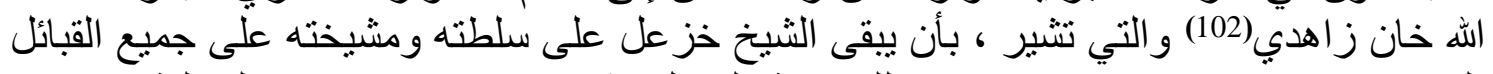

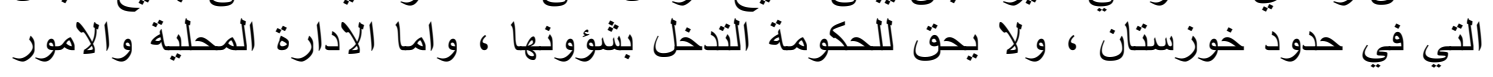


العسكرية فتكون تحت امرة القائد حاكم خوزستان ، و اما بقية الامور الأخرى فسينظر في امرها بعد ... "103)" ويبدو أن البعض من الحضور في هذا الاجتماع ومنه الثيخ صالح باش اعيان العباسي في فئي

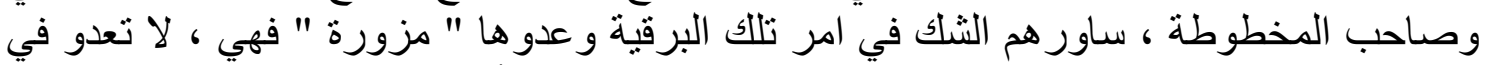

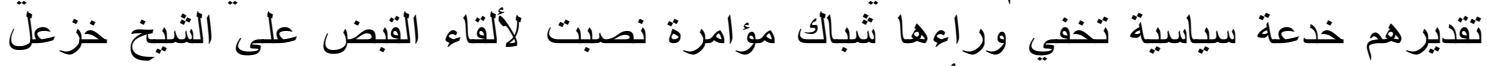

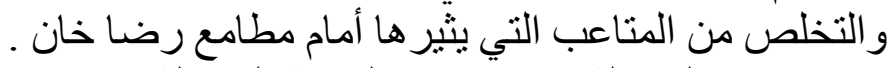

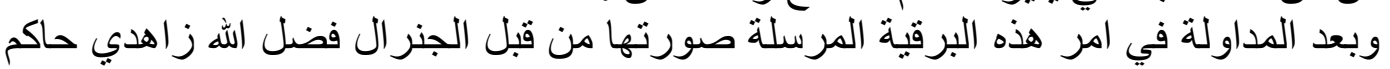

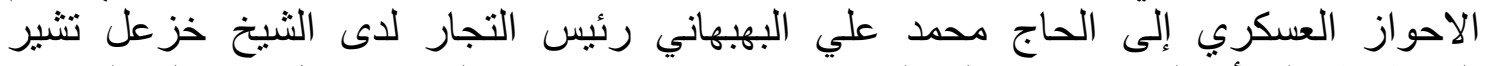

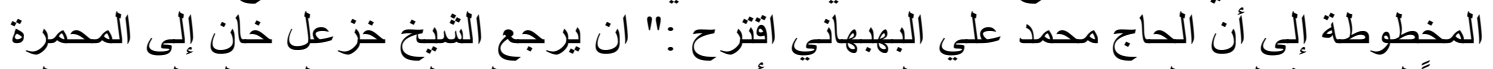

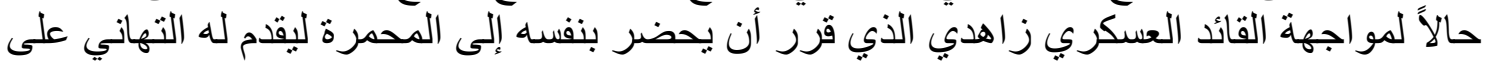

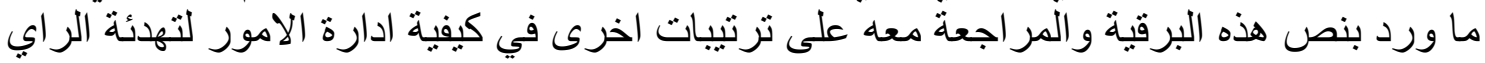

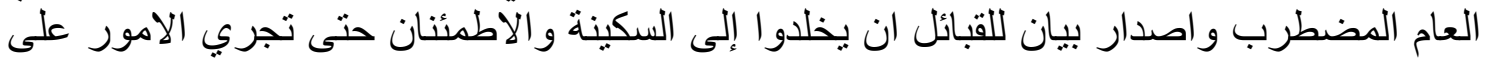

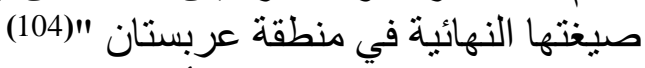

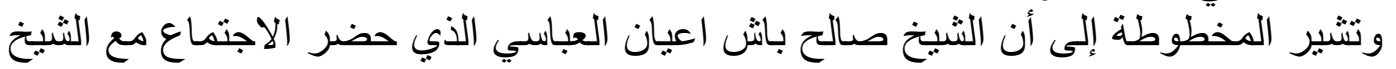

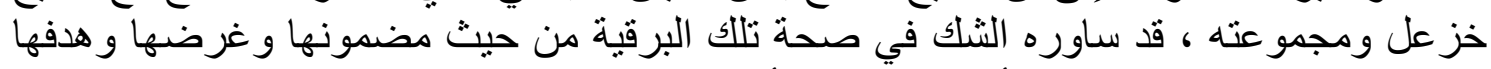

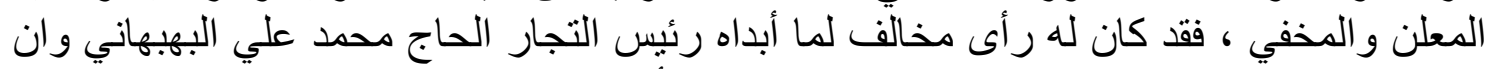

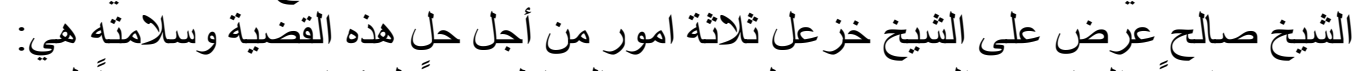

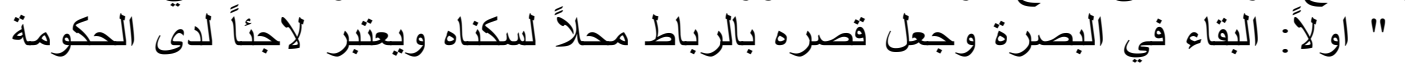

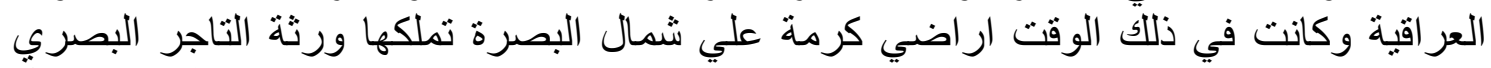

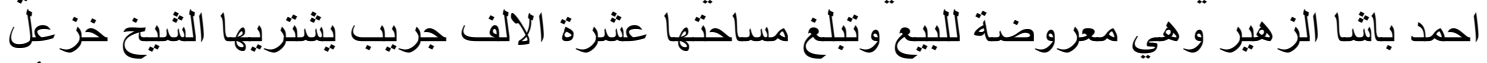

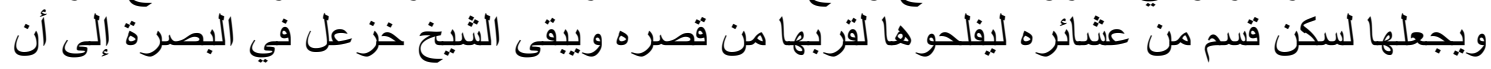

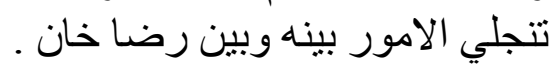

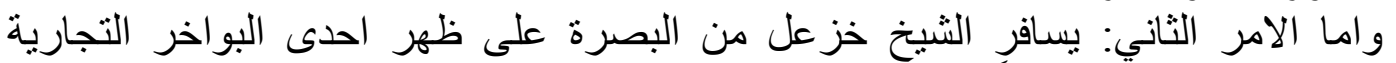

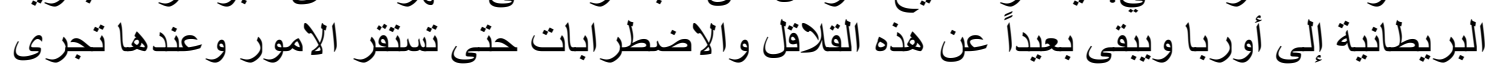

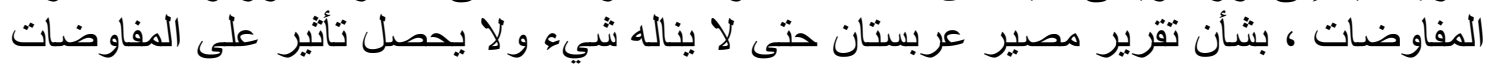

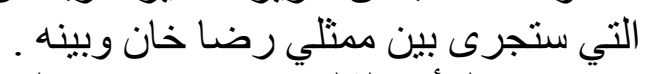

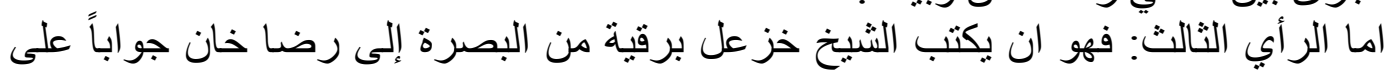

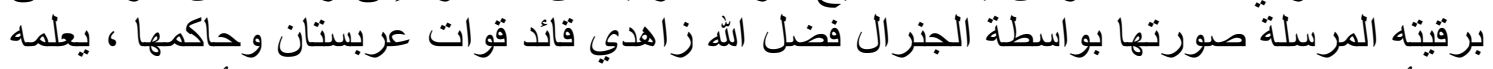

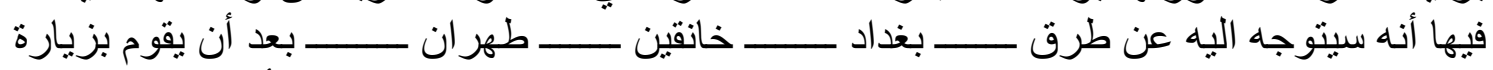

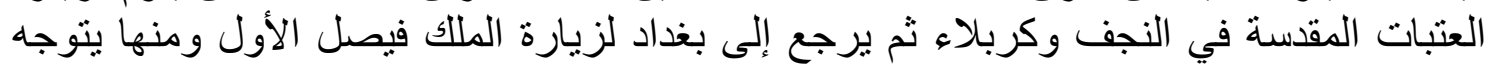

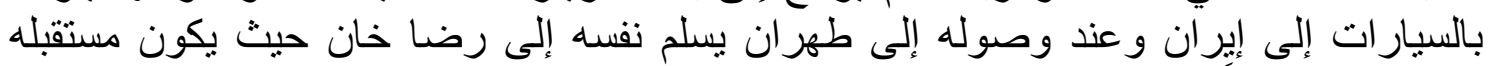

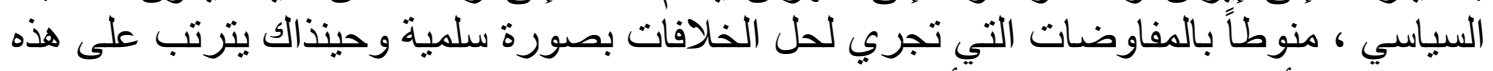

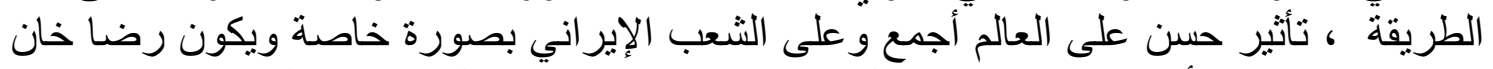

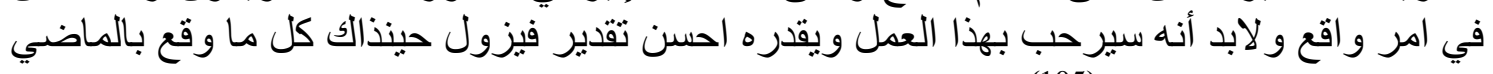

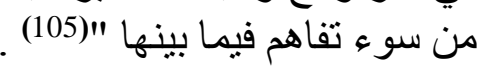

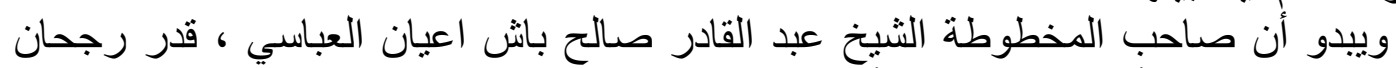

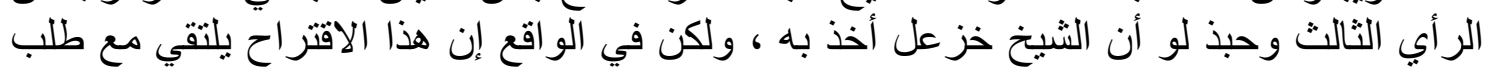




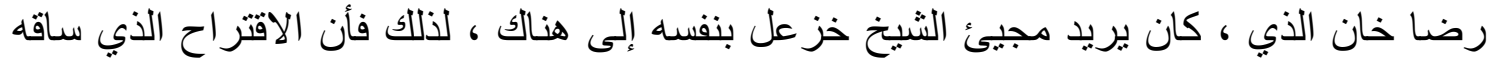

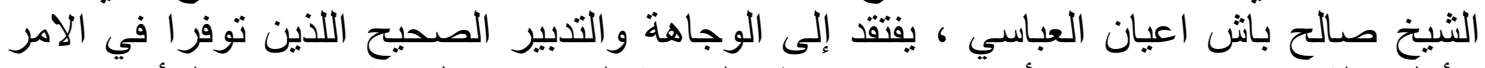

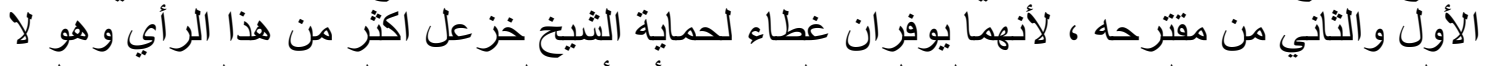

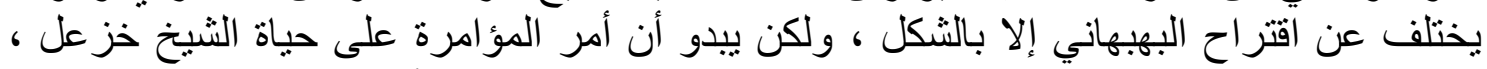

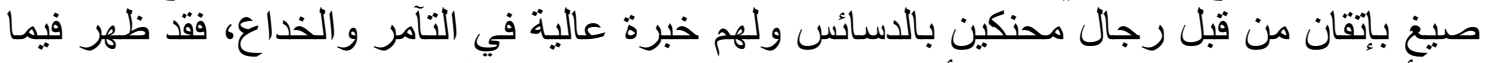

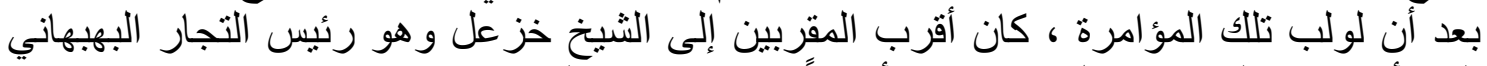

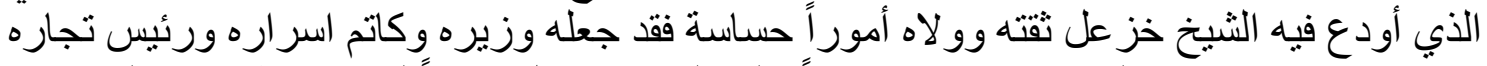

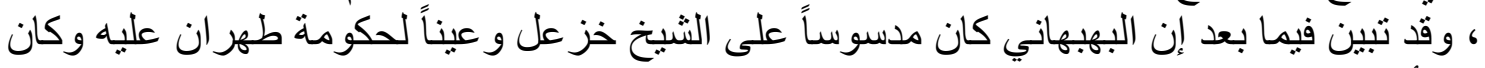

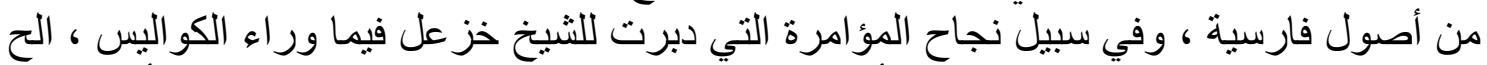

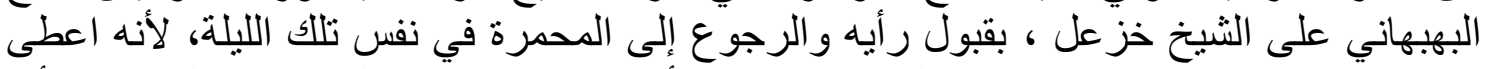

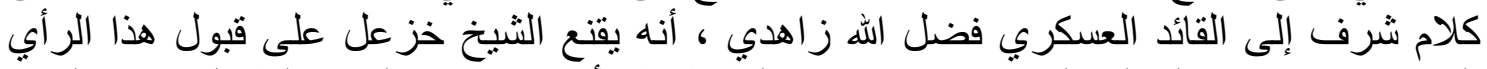

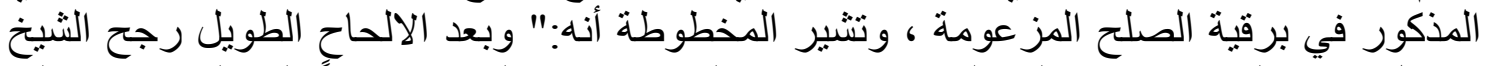

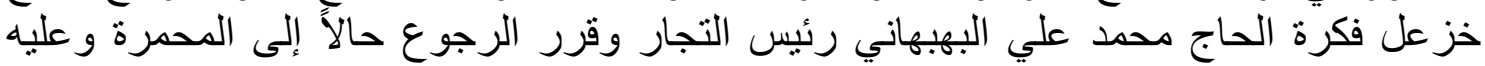

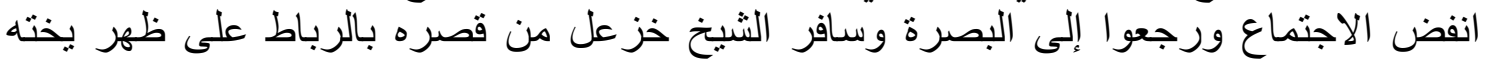

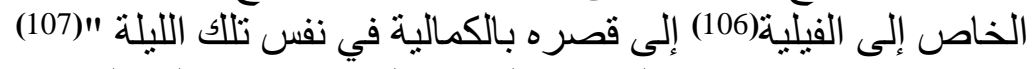

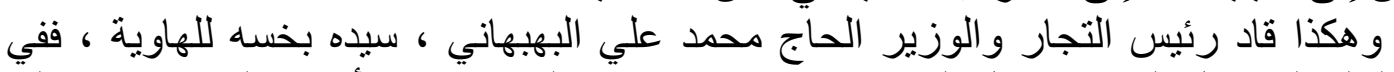

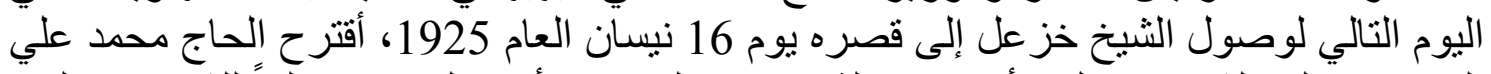

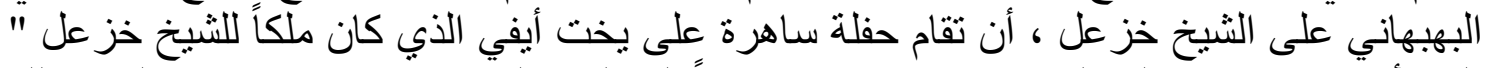

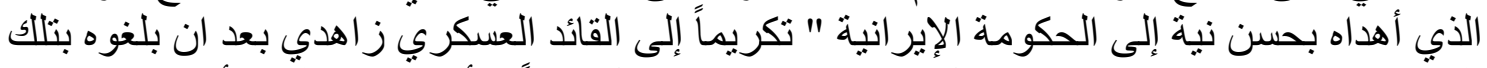

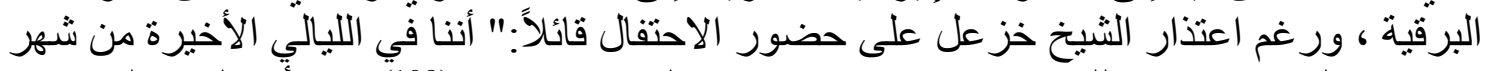

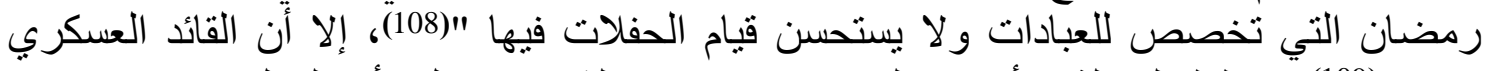

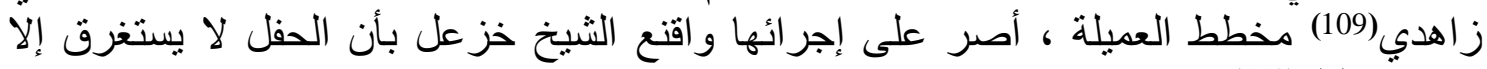
ساعات قلبلة(110) وفي ليلة 19- 20 نيسان العام 1925، اقيمت الحفلة على ظهر اليخت المذكور وكانت

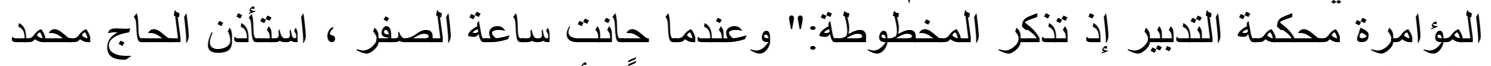

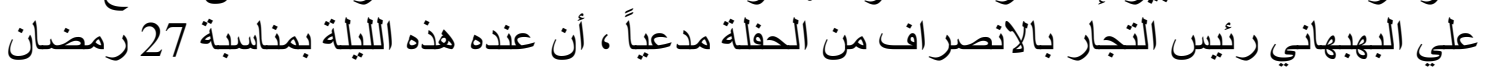

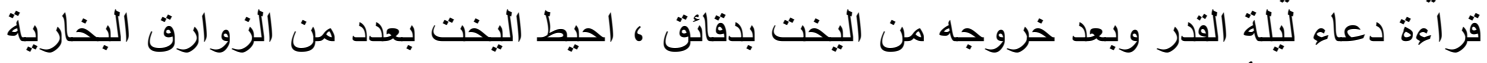

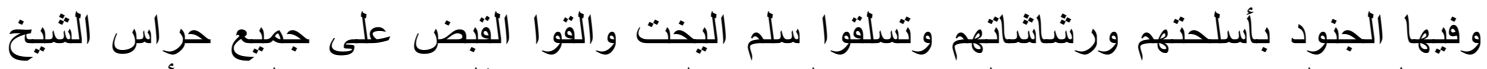

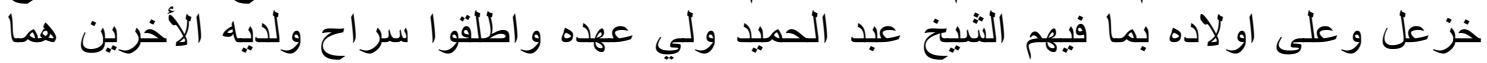

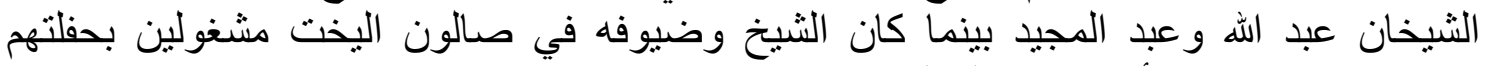
الر اقصة لا يعلم ما خبأ له القدر "(111)

الثيخ خز عل رهن الاعتقال

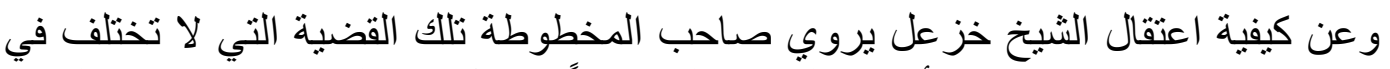

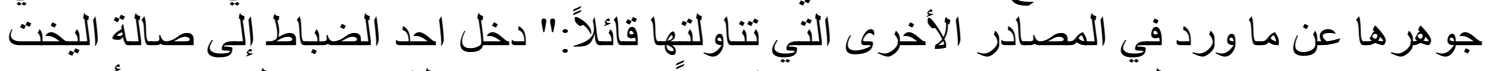

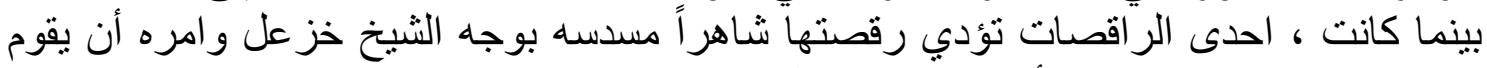

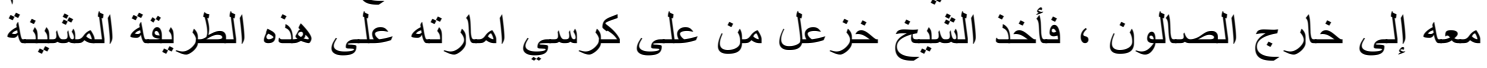


و انزل إلى أحدى القوارب البخارية التي كانت بجانب اليخت و الذي كان راسياً امام قصره الكمالية

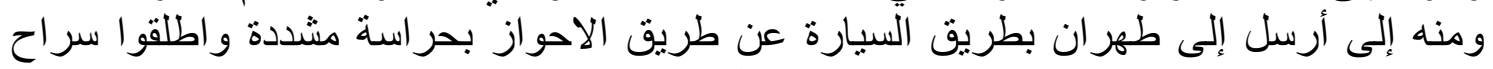

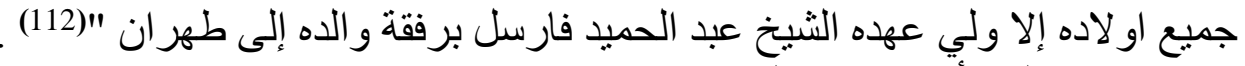
و هنا تظهر أمامنا ملاحظتان: الأولى: أن صاحب المخطوطة الثيخ عبد القادر باش اعلى اعيان العباسي ، لـ يكن مع الثيخ

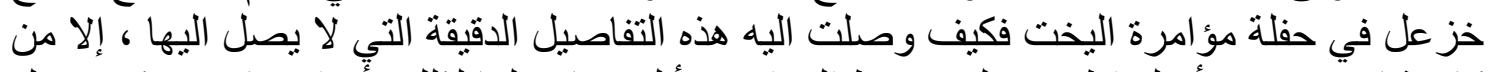

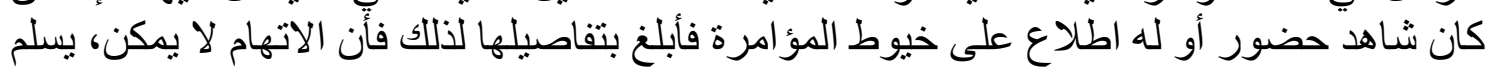

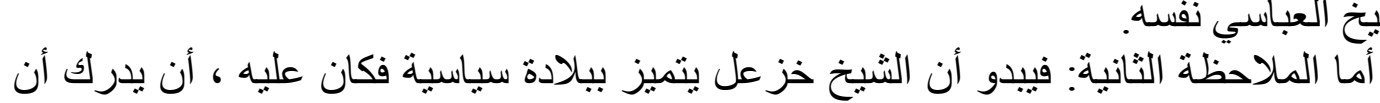
منه الثيخ العباسي نفسها.

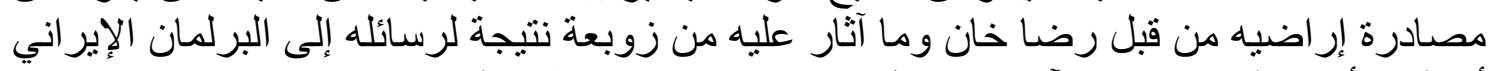

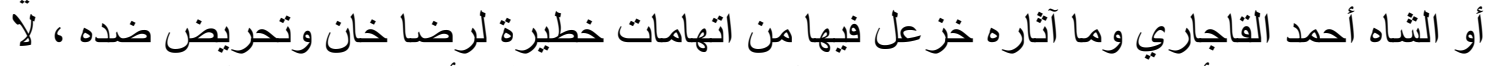

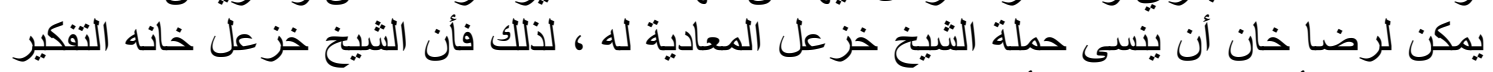

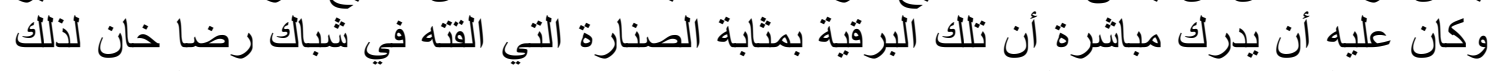

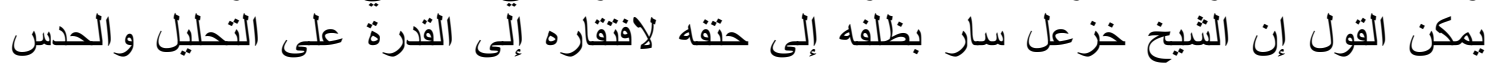

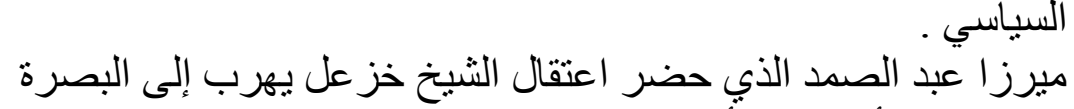

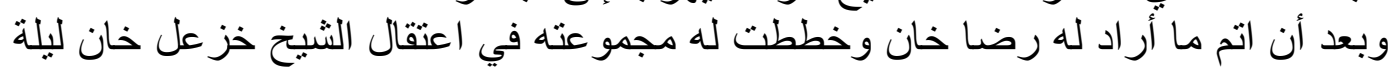

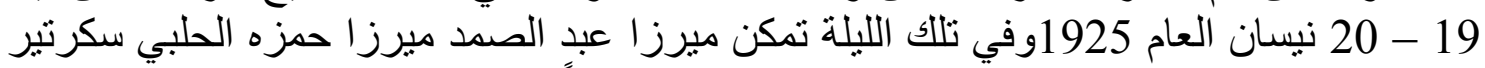

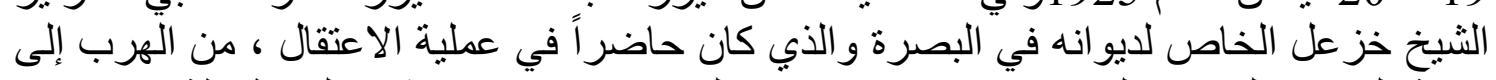

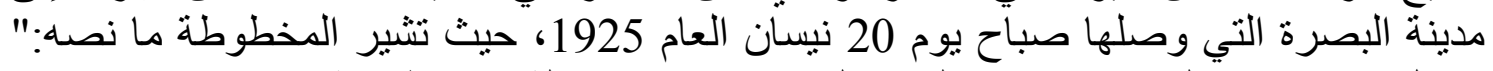

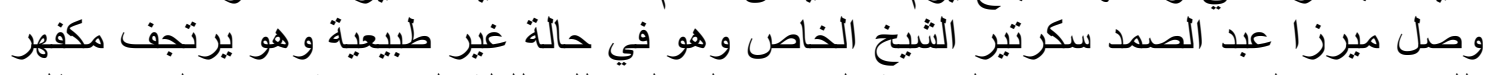

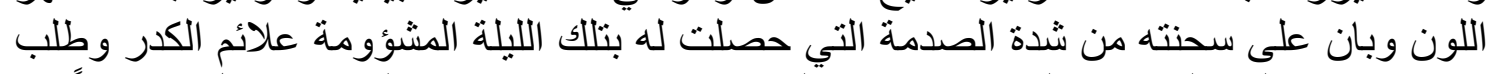

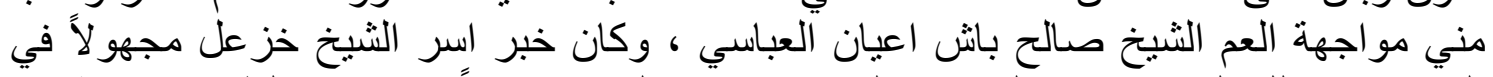

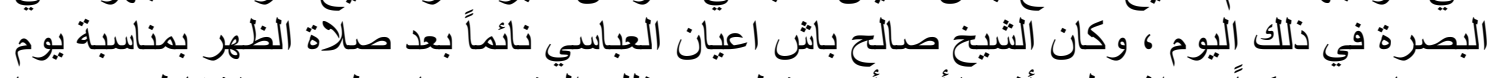

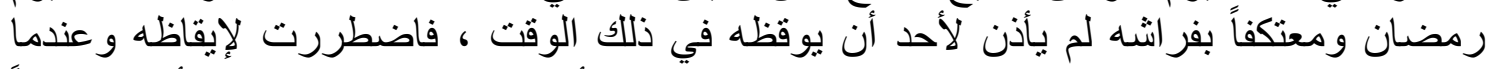

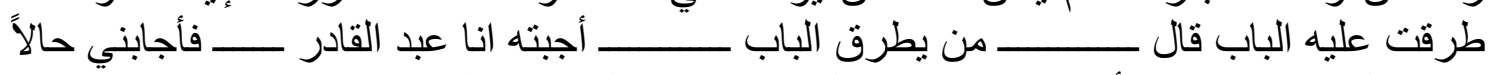

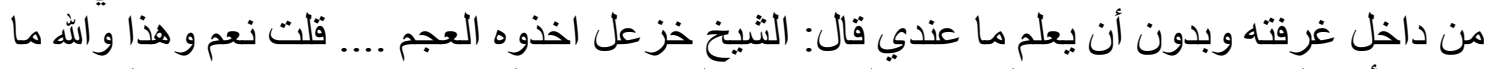

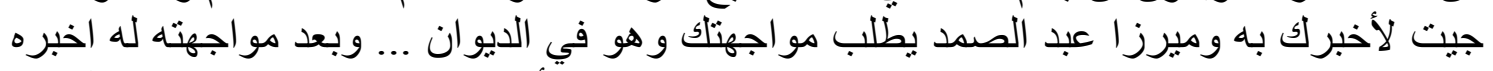

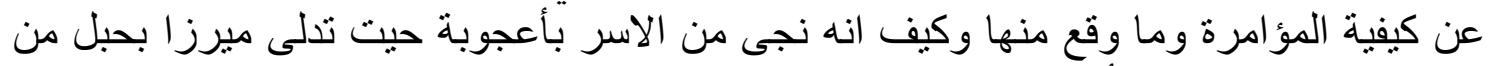

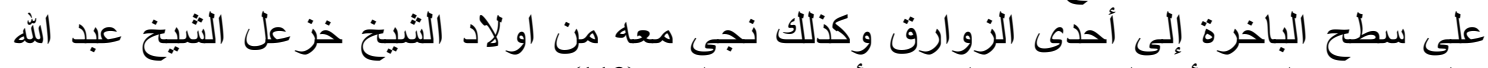

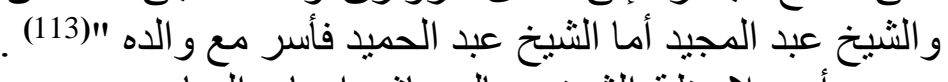

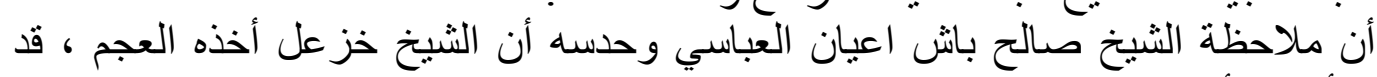

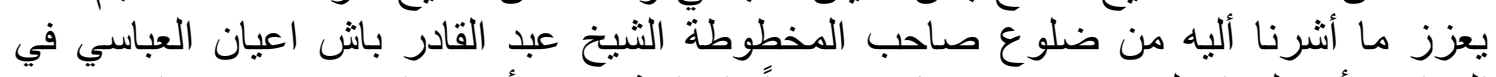

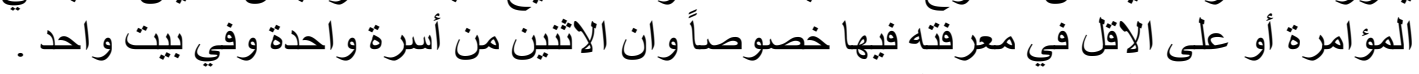

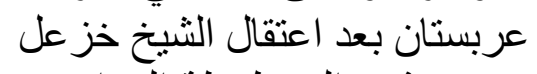

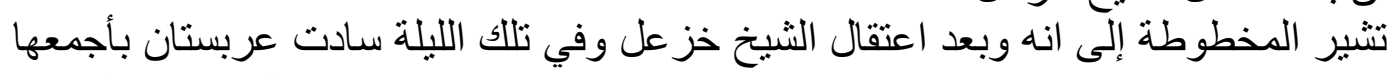

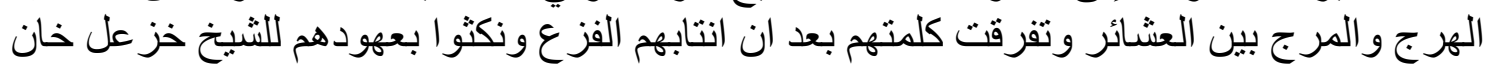




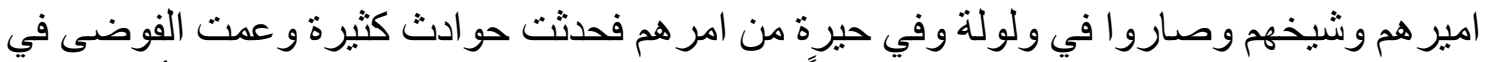

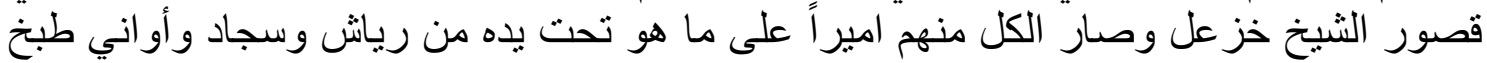

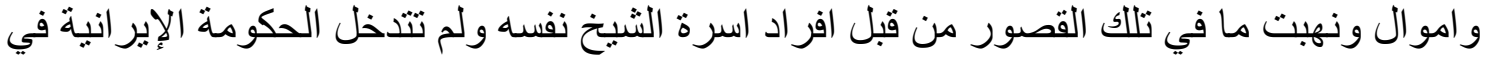

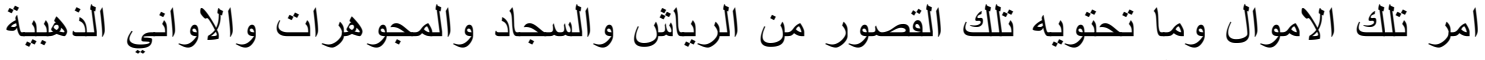

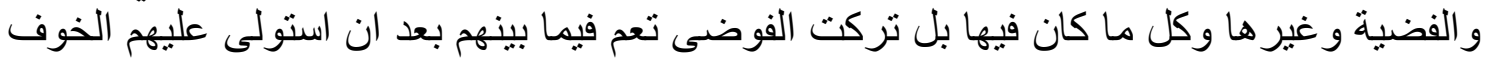

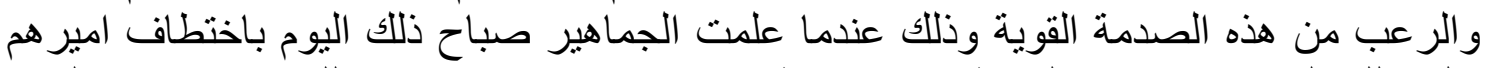

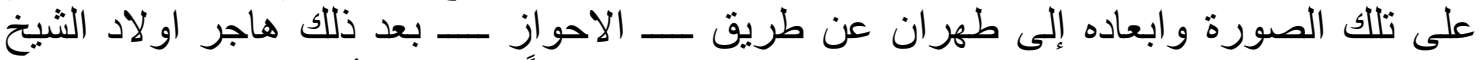

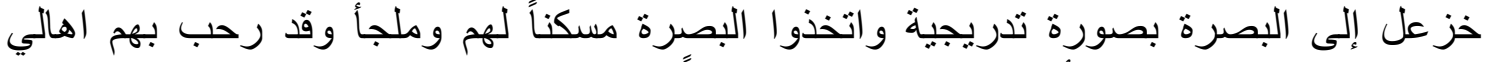
البصرة احسن ترحيب كما أن الحكومة العر اقية ايضاً قد شملتهم بر عايتها وفتحت لتهن لهم الحدود بدون أي قيد وشرط وقد بقي القليل منهم في المحمرة "(114)

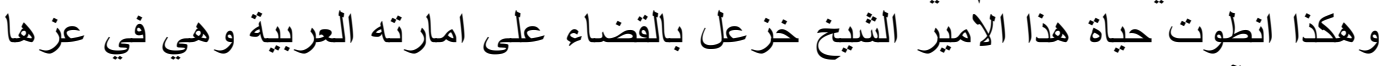

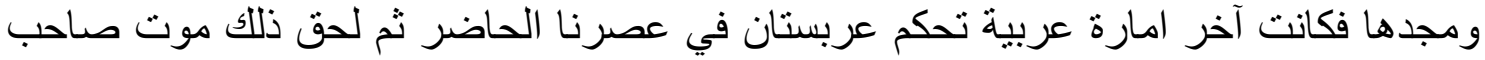

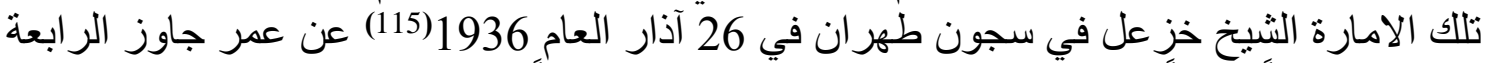

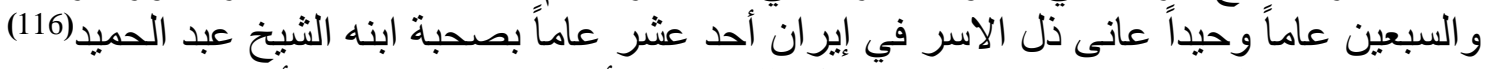

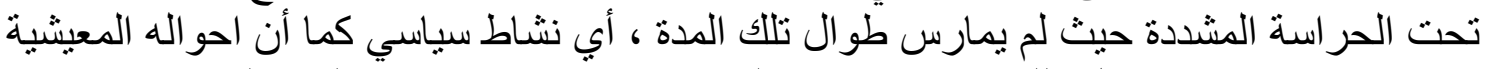

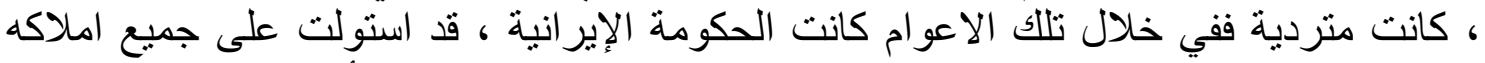

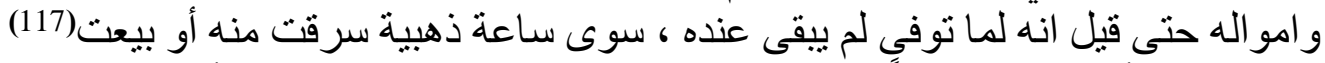

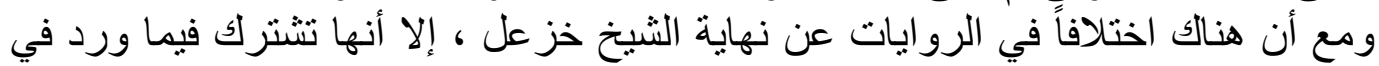

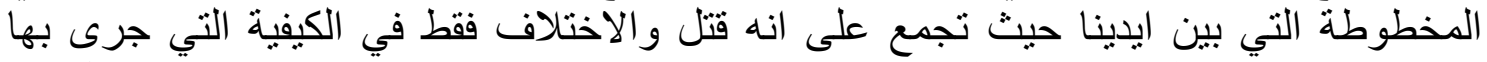

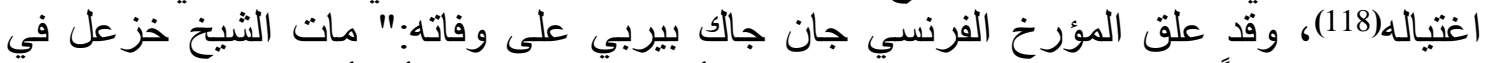

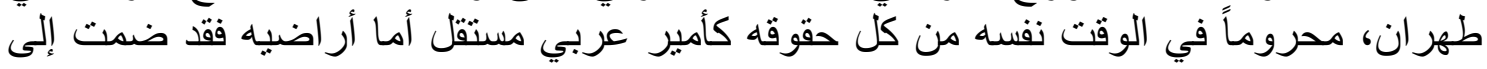

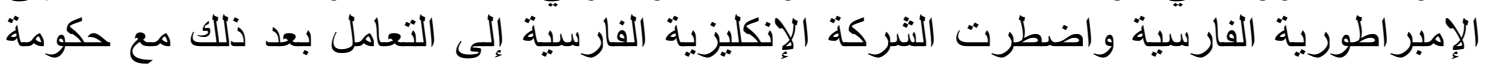
طهر ان"(119) مبر الطورية

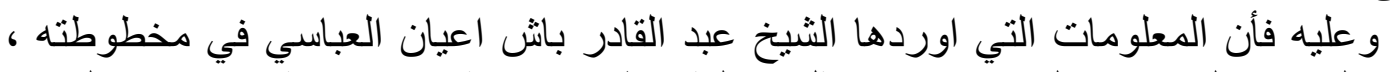

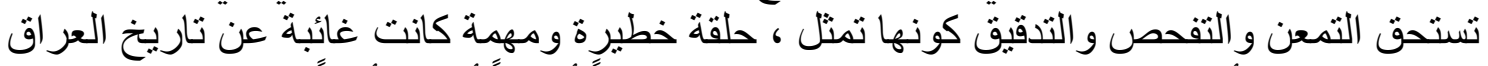

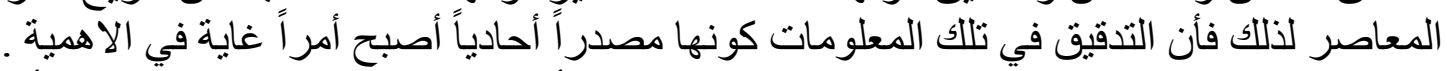

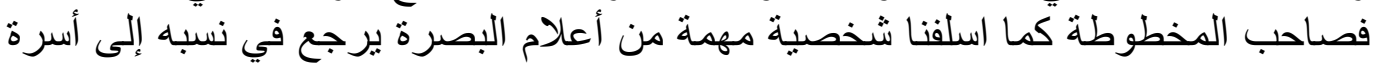

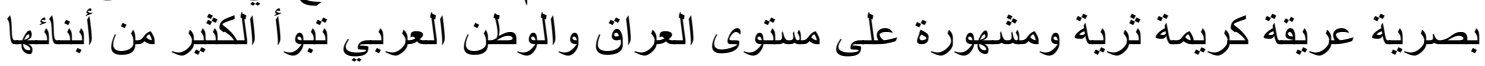

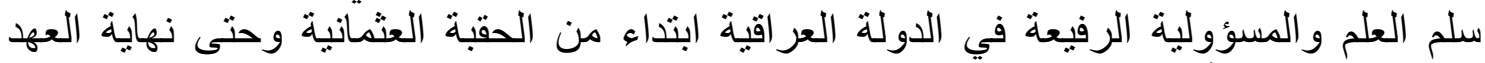

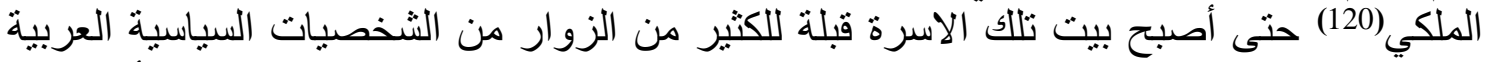

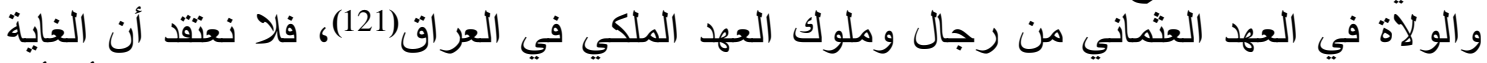

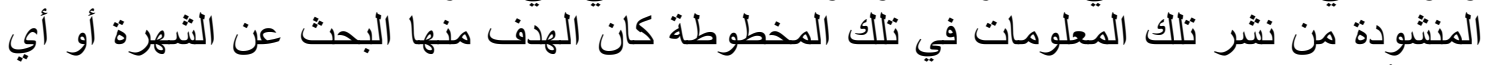

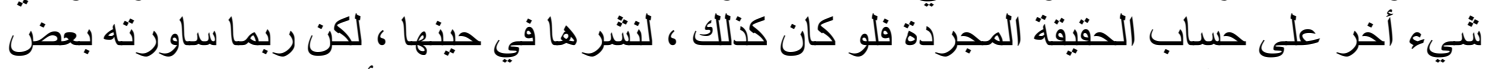

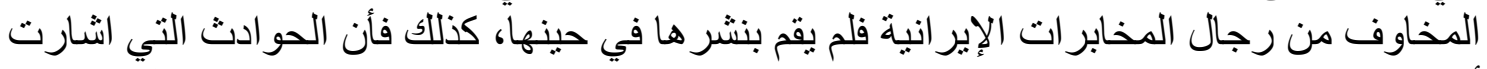

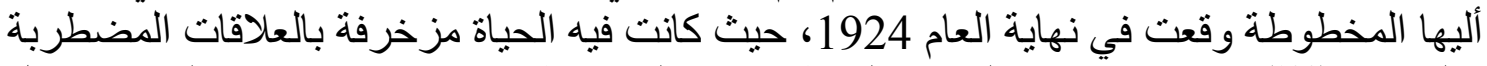

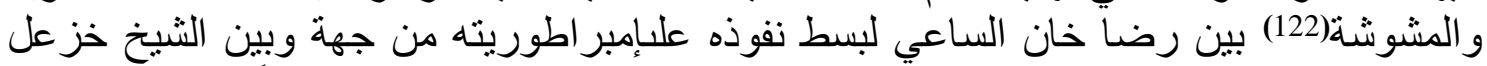

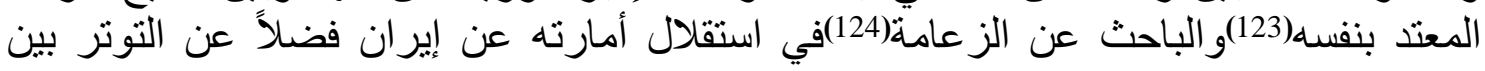




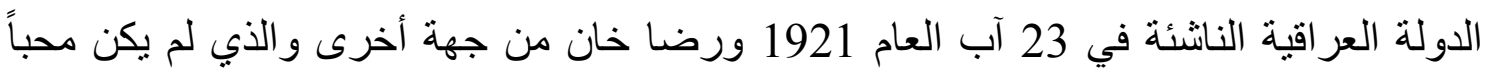

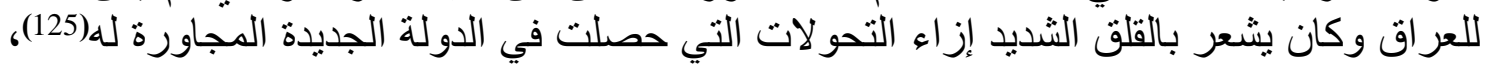

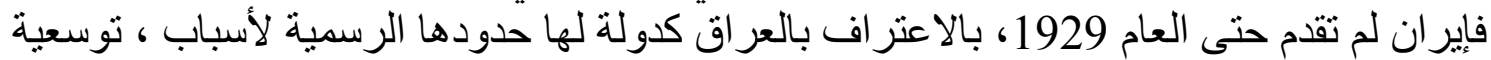

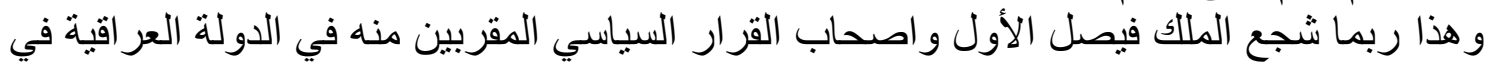

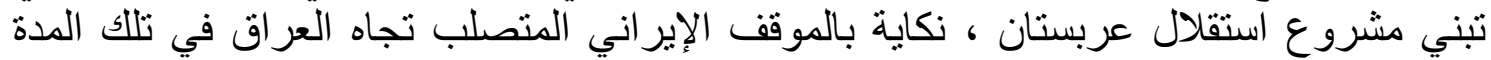

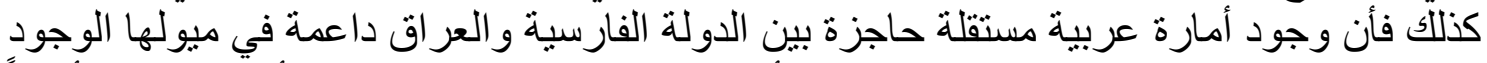

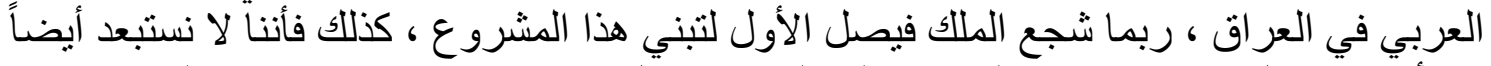

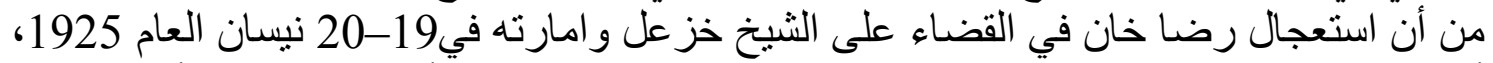

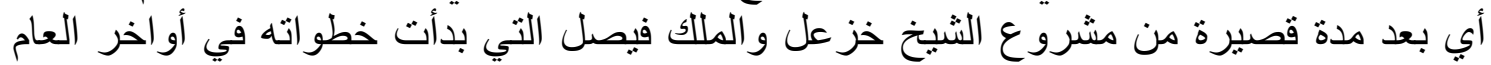

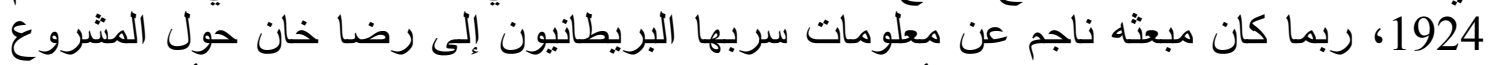

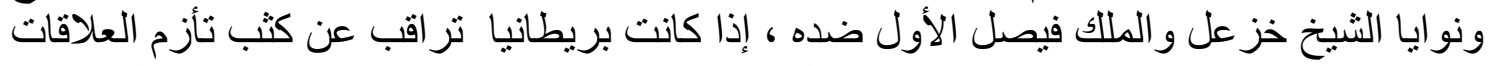

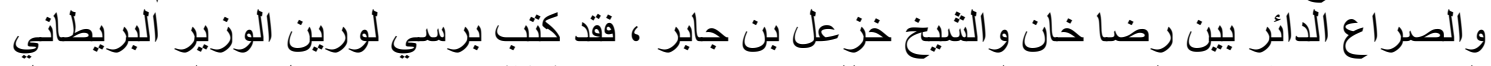

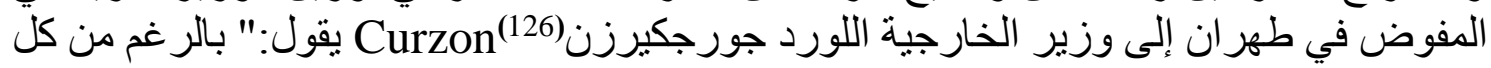

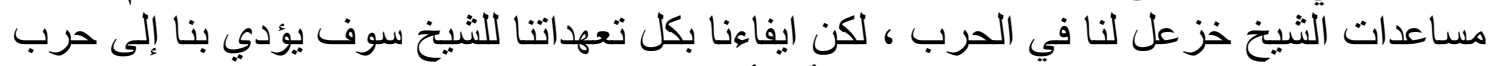

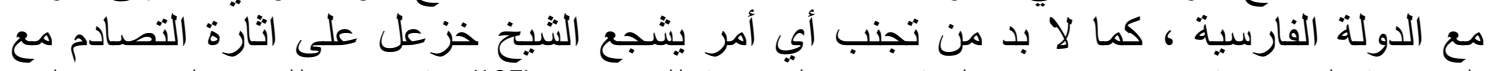

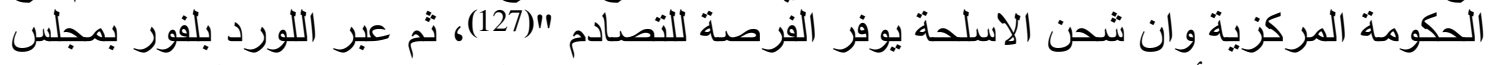

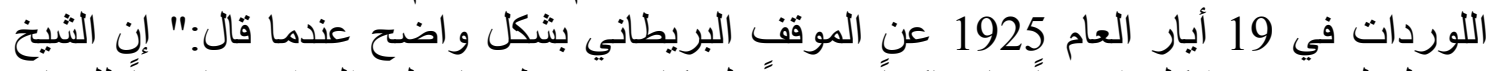

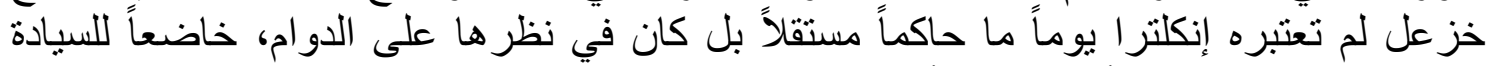

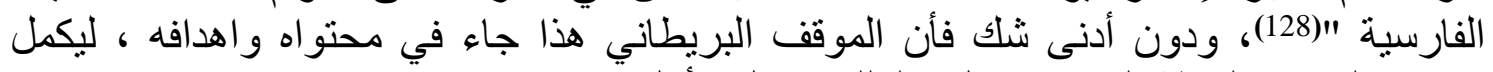

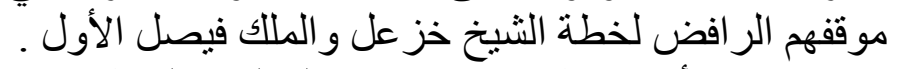

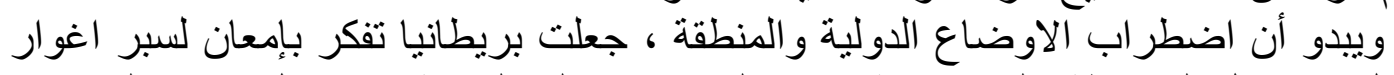

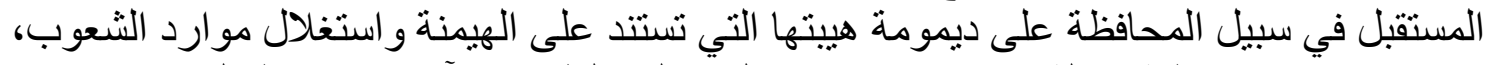

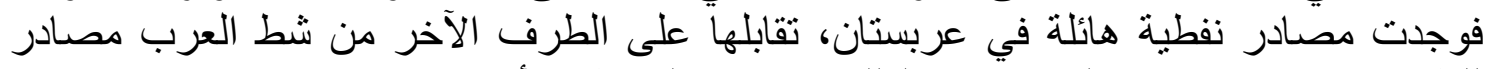

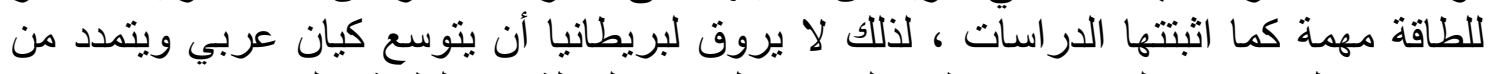

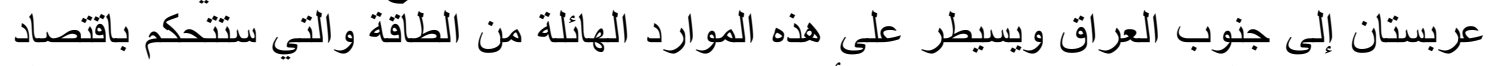

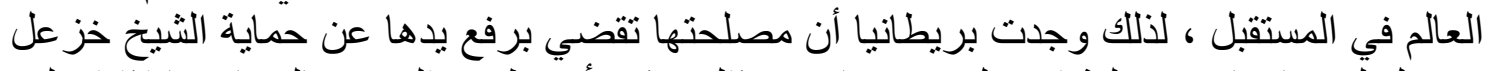

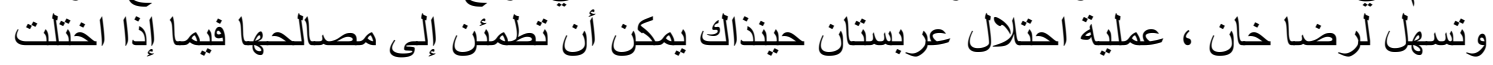

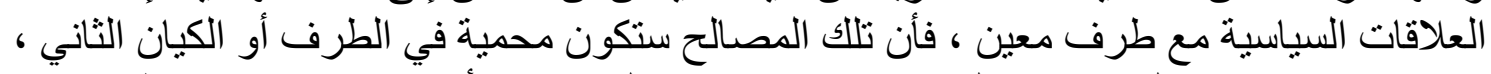

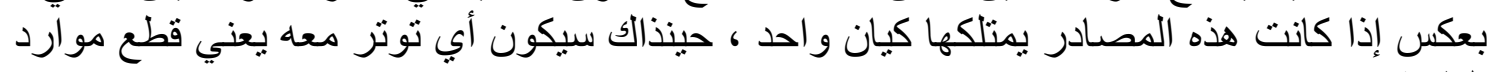

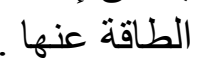

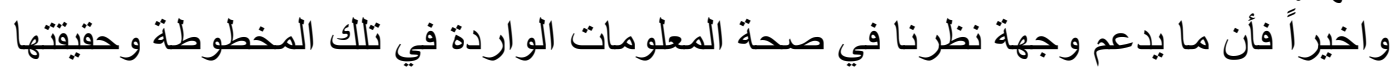

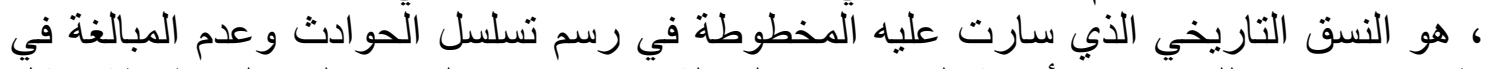

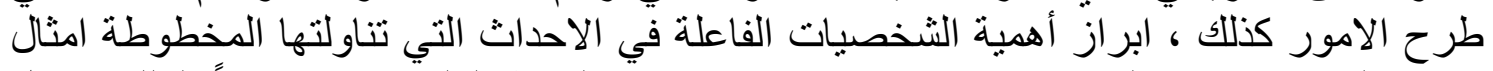

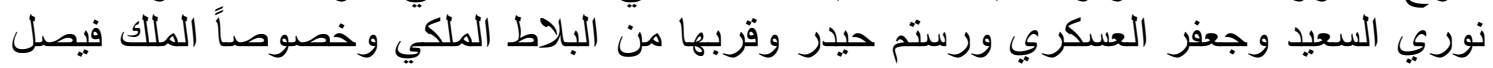
الاول الذي تبنى تلك الفكرة .

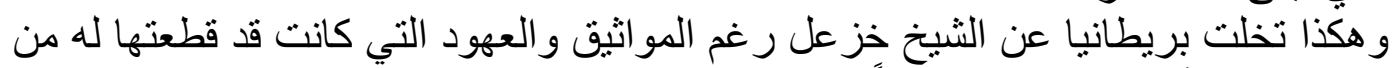

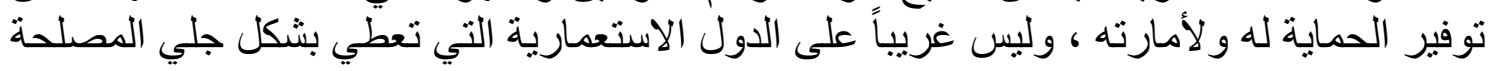


الاستراتيجية وخصوصاً في منطقة الخليج العربي، الاهمية الأولى لأن وجودها الدولي يعتمد على الأى

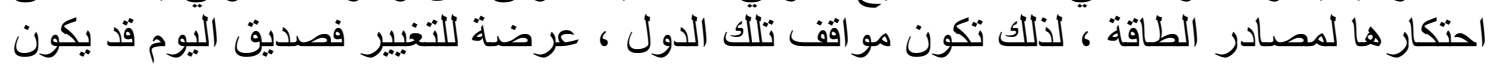

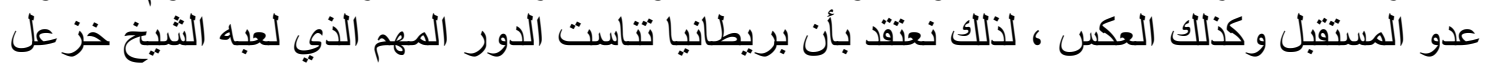

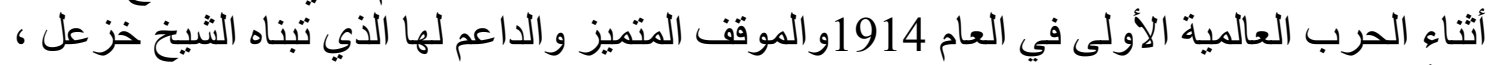

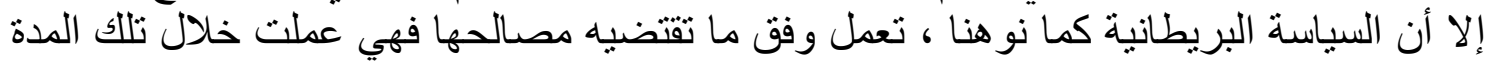

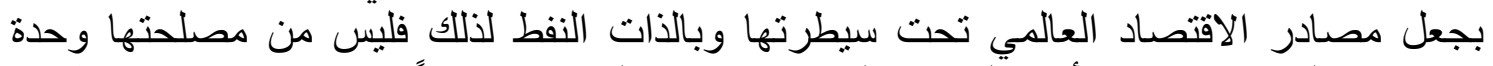

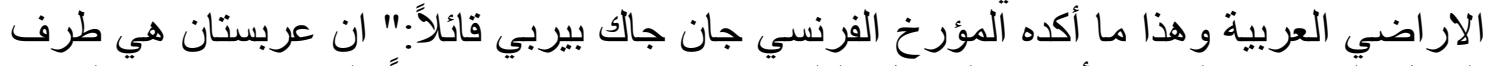

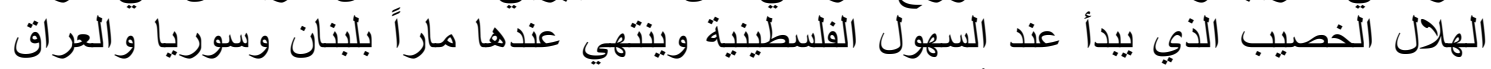
"(129)، فبريطانيا سلمت الطرفين أحدهما لفارس و الآخر لليهود في فلسطين.

\section{الخاتمة}

لم تكن العلاقات العر اقية الإير انية و على مدار حقب تاريخية طويلة ، تسير بالاتجاه الطبيعي

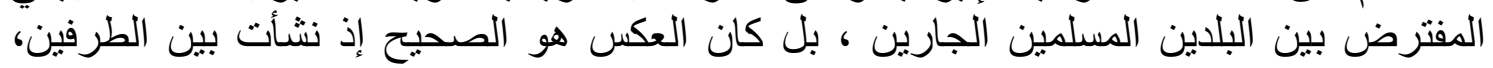

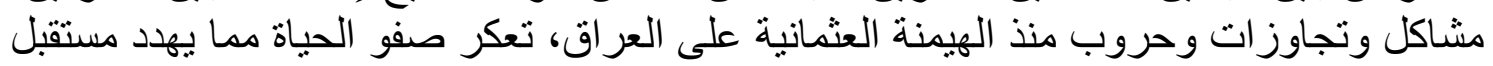

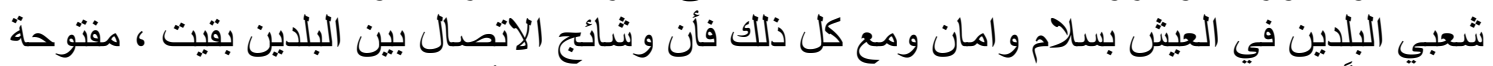

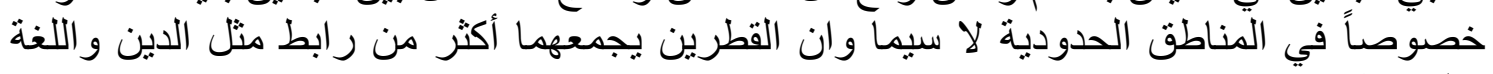

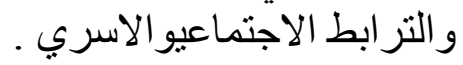

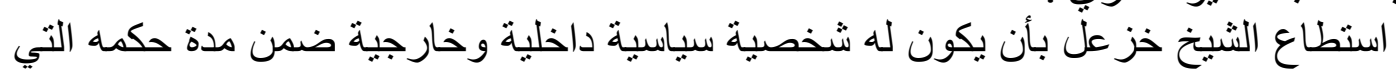

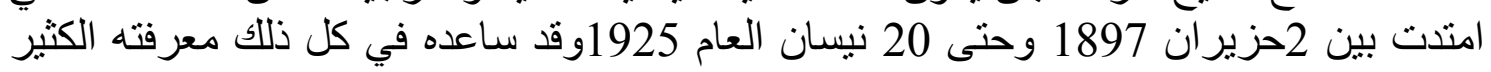

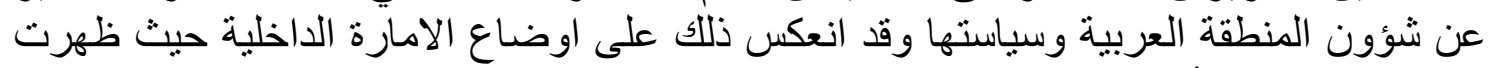

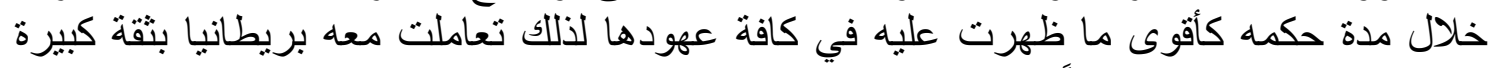

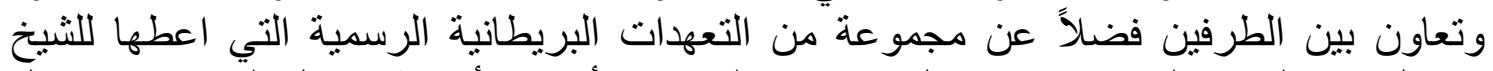

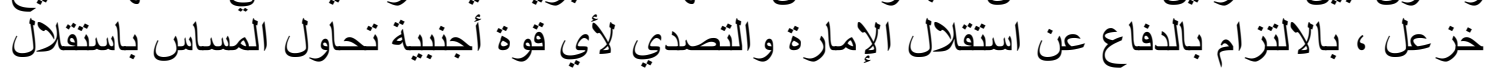

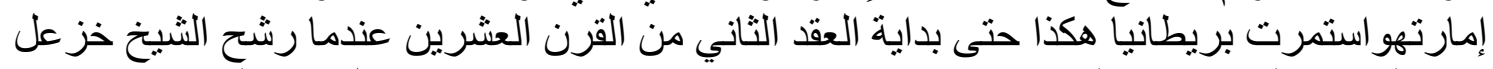

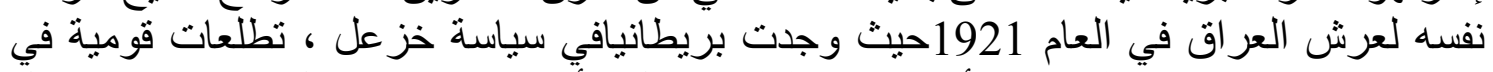

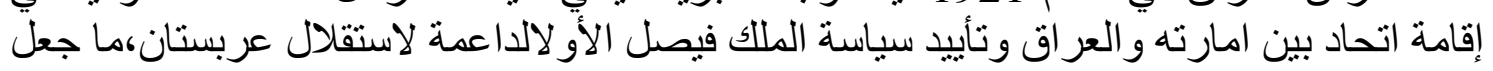

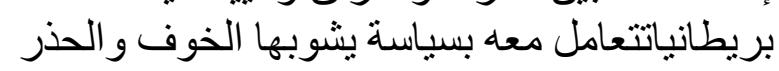

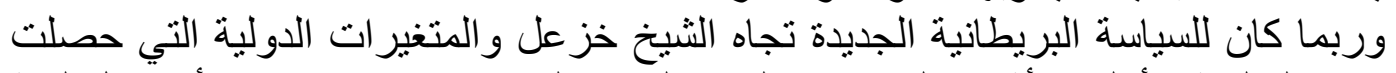

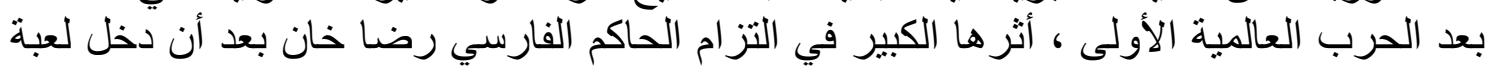

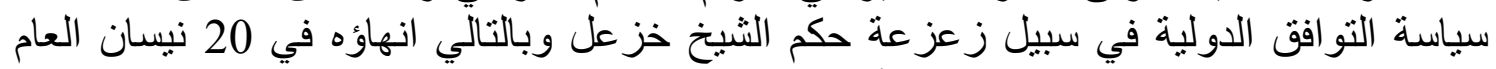

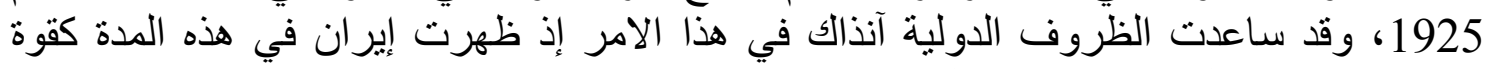

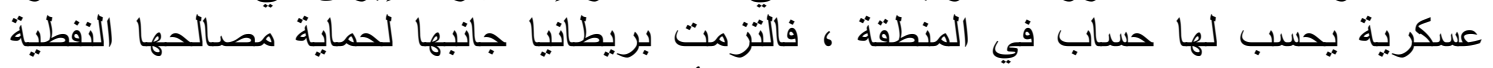
و اهملت الثيخ خز عل ليو اجه مصيره بمفردهكذلك فأن تللك الدولتين اللتين لهما مصالح في التيانة المنطقة

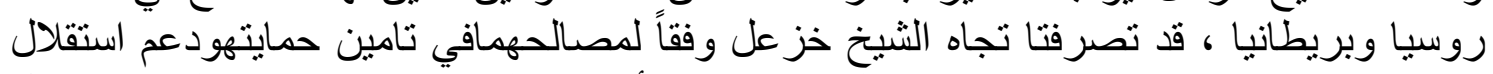

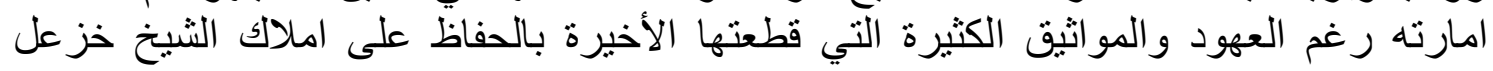




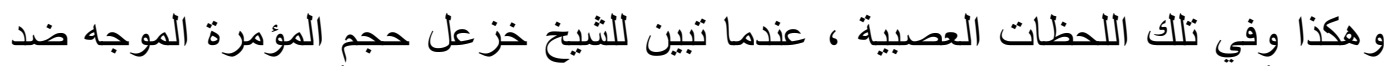

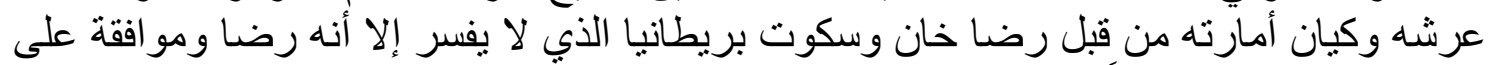

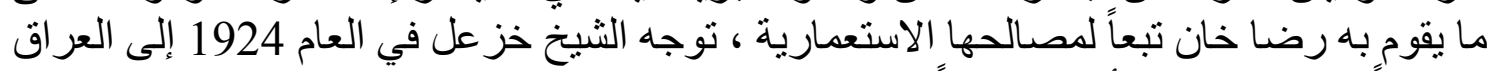

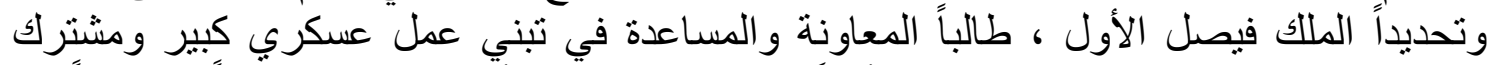

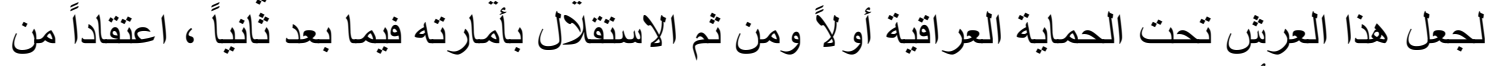

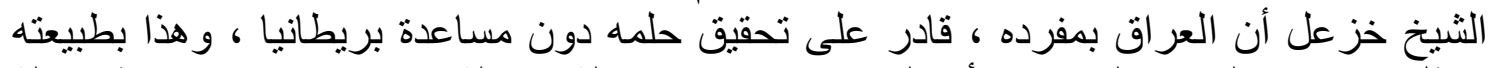

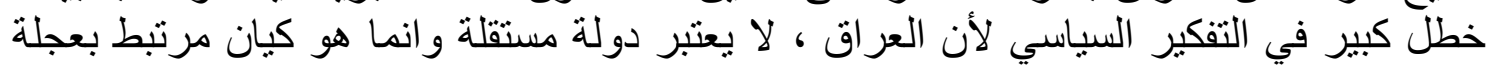
السياسة البربطانية.

و على الرغم من قبولية الملك فيصل الأول ، بمشروع الثيخ خزعل و اتخاذه خطوات عملية

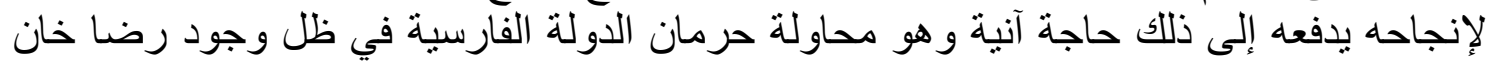

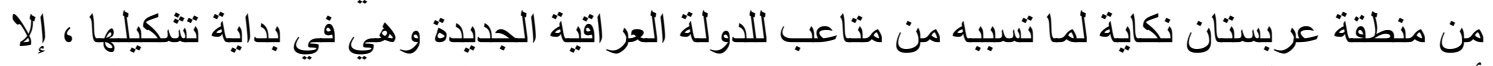

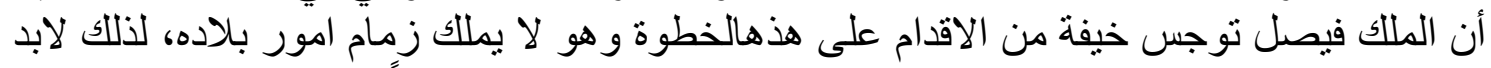

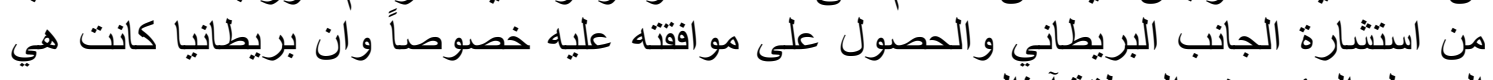

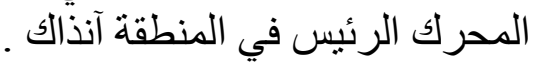

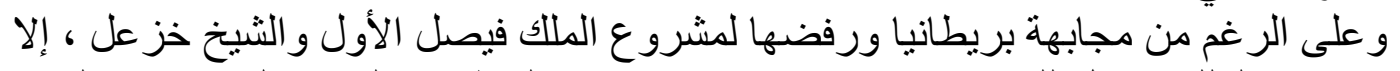

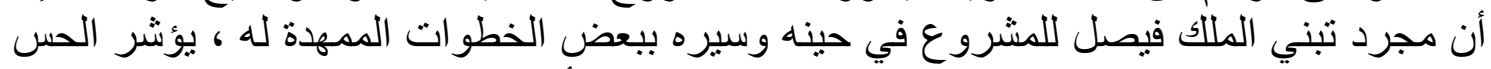

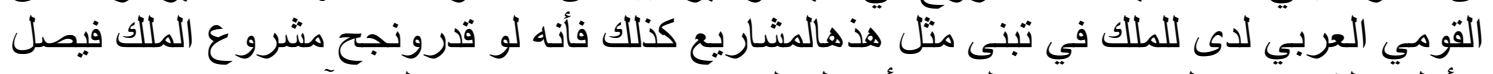

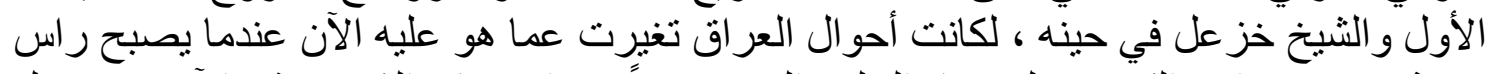

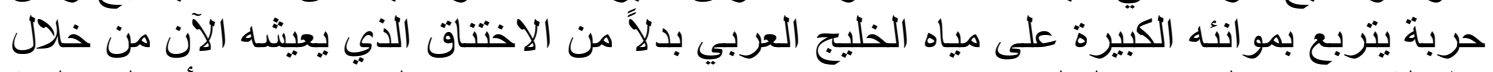

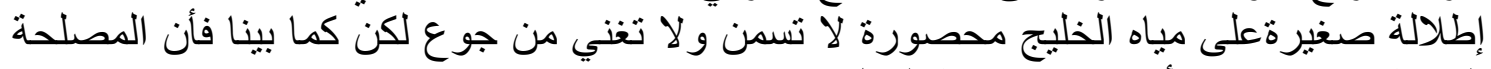

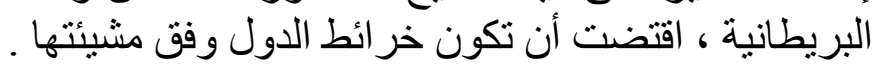

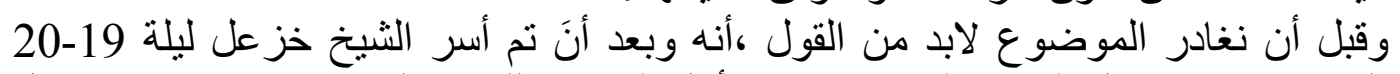

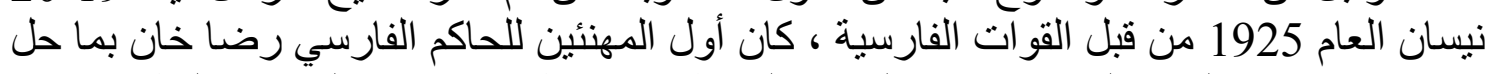

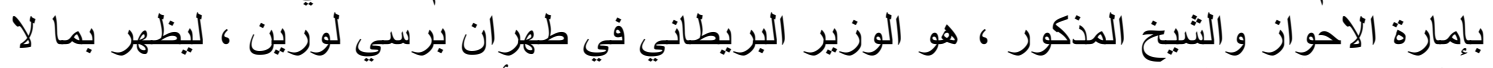

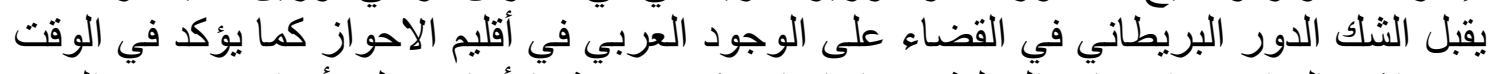

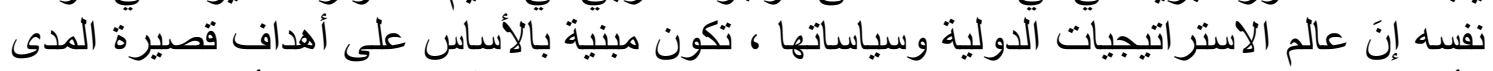

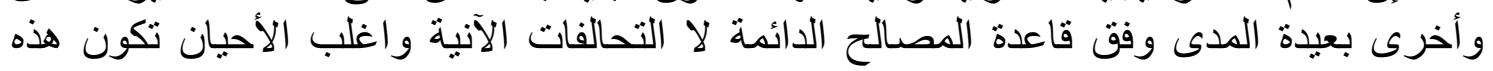

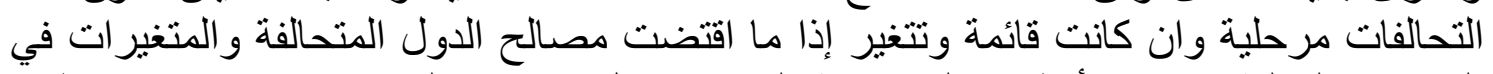

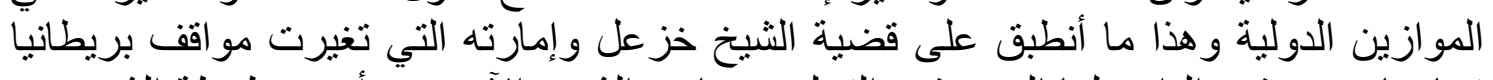

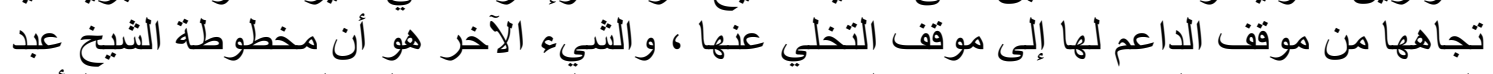

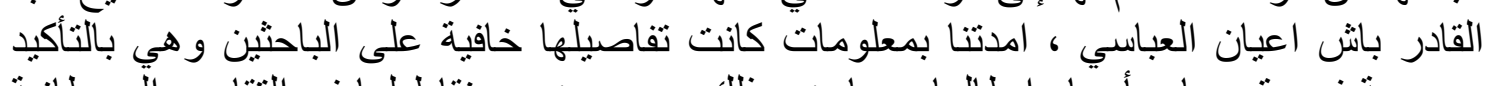

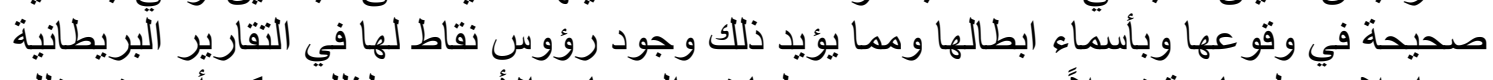

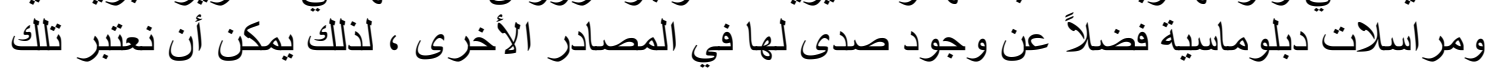

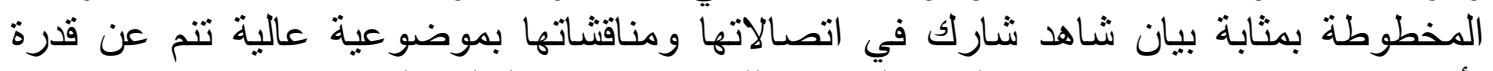

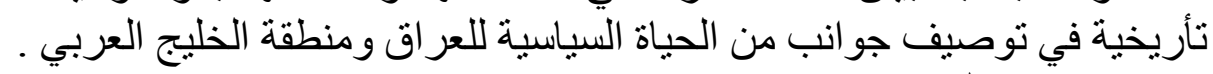
هو امش البحث توفي 
(1) الثيخ عبد القادر الثيخ عبد الواحد الثيخ عبد الله ضياء الدين باش اعيان العباسي ولا في البصرة في العام 1893 وتربى برعاية جده الثيخ عبد الله ضياء الدين باش اعيد الثيان ثم دخل

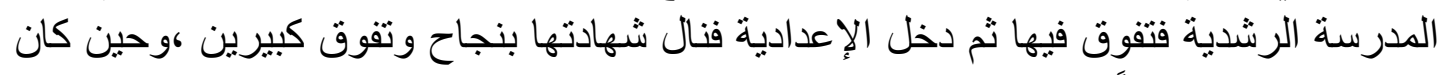

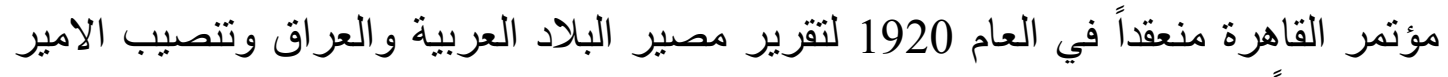

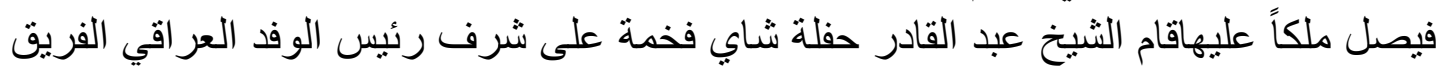

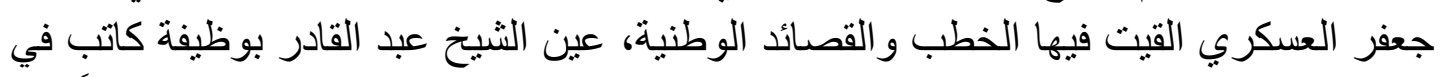
العدلية في العام 1943 بعدها أنصرف للعمل التجاري ثم انتخب في العام 1943 نائباً عن

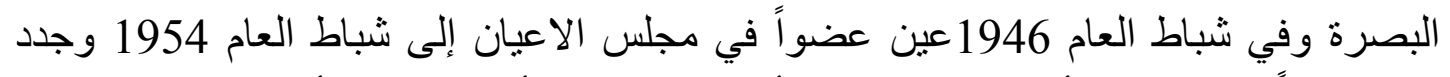

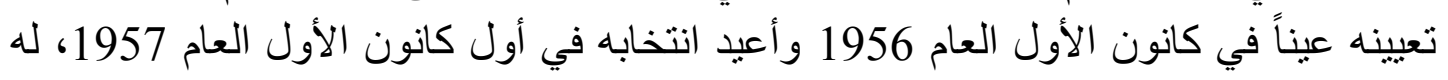

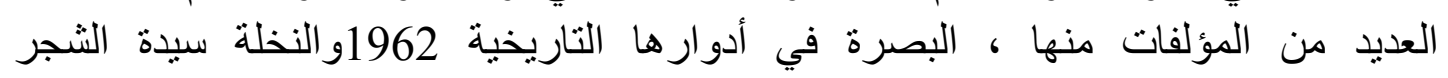
1964ومسجد جامع البصرة الكبير 1968 وموسوعة تاريخ البصرة 1988، ونشئ ونشر العباسي كتاب " زاد المسافر ولهنة المقيم والحاضر فيما جرى لحسين باشا ابن أفر اسياب حاكم البصرة

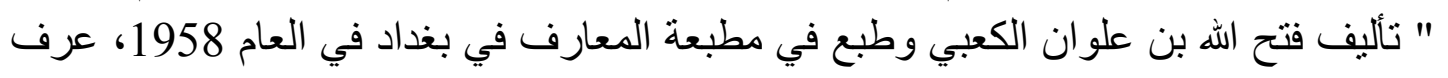

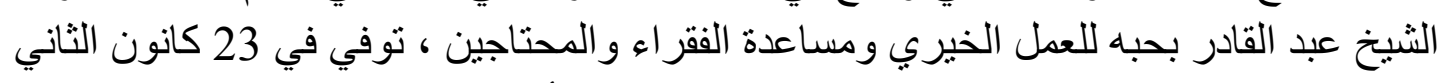

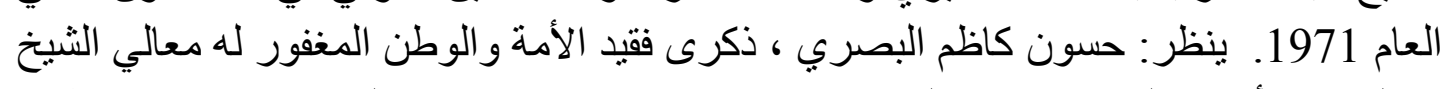

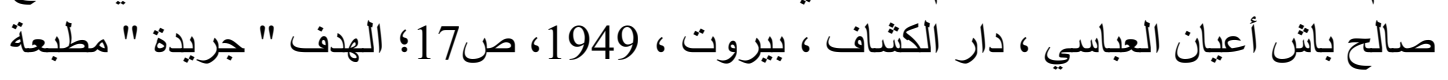

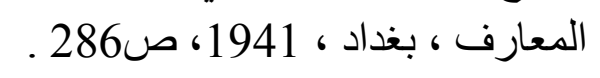

(1) من المناسب أن نشير هنا إلى أنهاينما ترد كلمة فارسفي هذا البحث والتي أصبحت تسمى إيران في العام 1935 فأن المقصود بذلكهو بلاد إيران الحالية.

(1) عن تفاصيل مؤلفاتهم ـ ينظر قائمة المصادر .

(1) الثيخ عبد القادر باش اعيان العباسي، الاحواز و عربستان في تاريخنا ، الجزء الأول ، المجلد

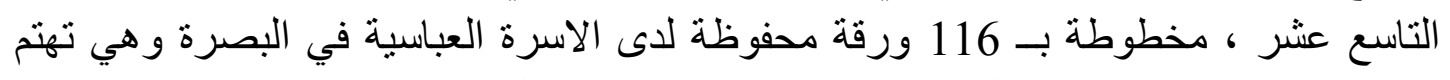

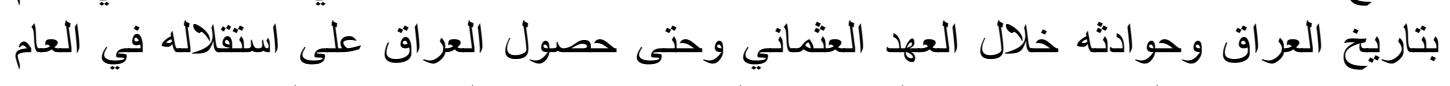

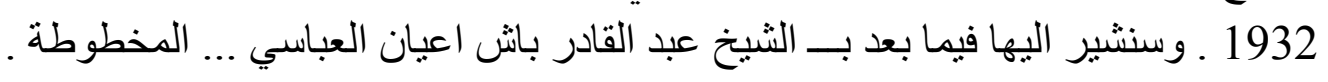

$$
\text { (1)(الثيخ عبد القادر باش اعيان العباسي ...المخطوطة ، الورقة رقم } 2 \text {. }
$$

(1) يذكر صاحب المخطوطة ما نصه:"القصر المذكور كان مقراً لأمارة الثيخ خزعل ويقع على القي ضفة نهر الكارون من جهته الجنوبية وانا قضيت فيه ليلة واحدة عندما كنت بضيافته في اوائل مئل

سنة 1923 " . ينظر: الثيخ عبد القادر باش اعيان العباسي ، المخطوطة ...، الورقة 77. 


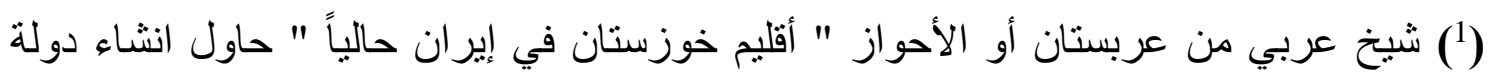

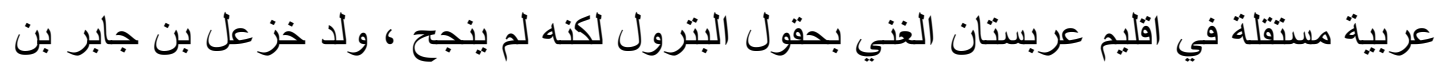

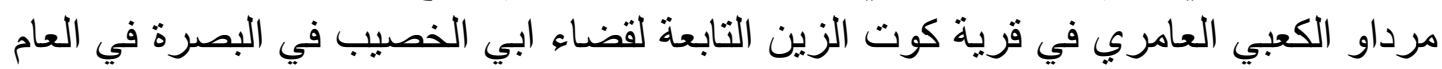

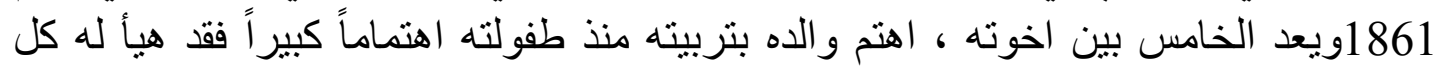

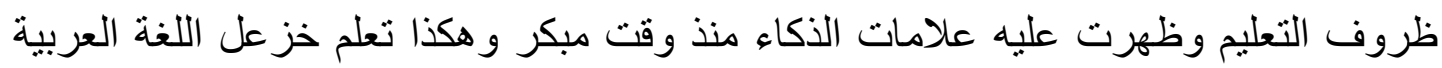

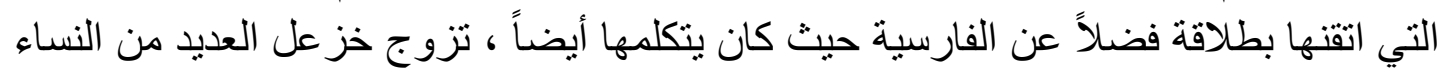

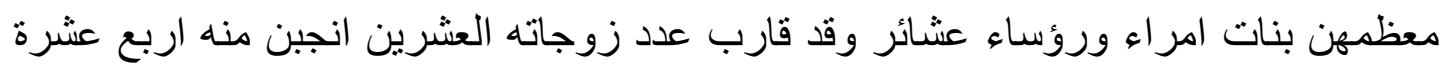

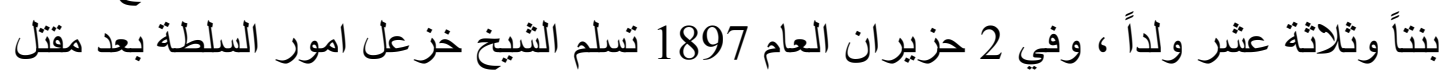

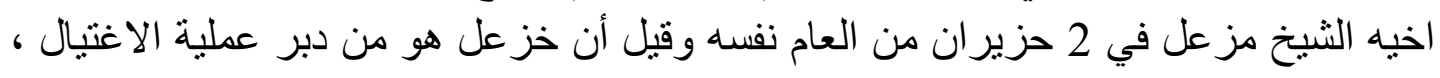

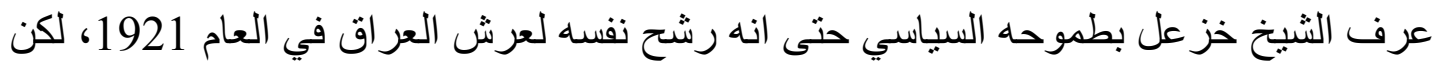

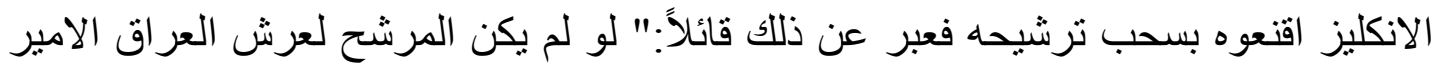

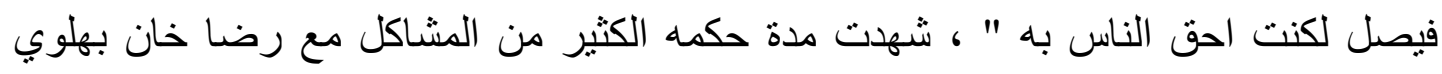

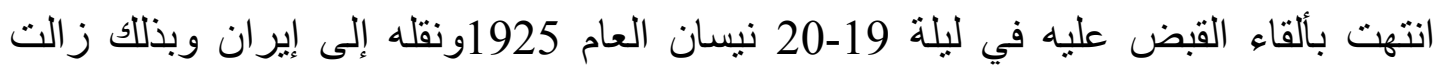

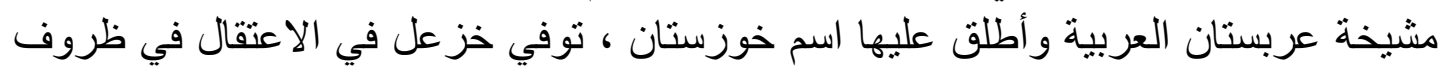

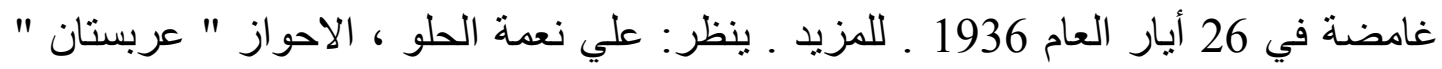

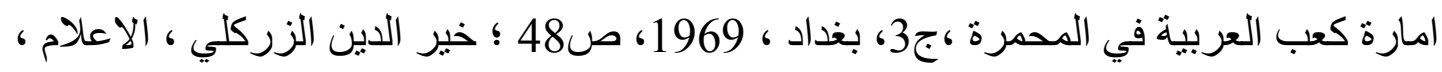

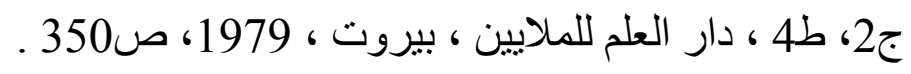

(1) ولدالثيخ صالح عبد اله ضياء الدين باش اعبان العباسي في البصرة في العام 1874 ثم دخل

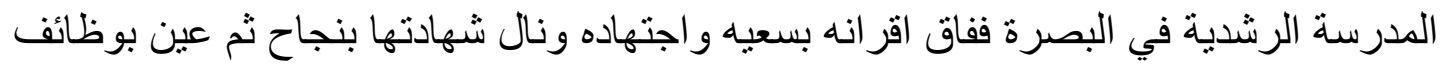

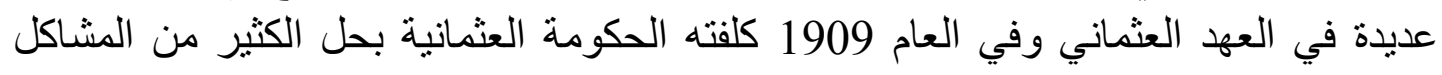

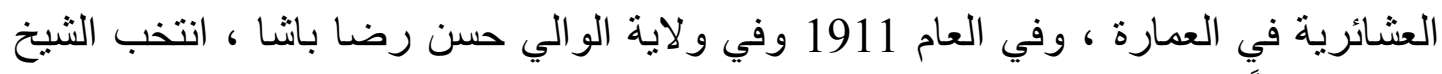

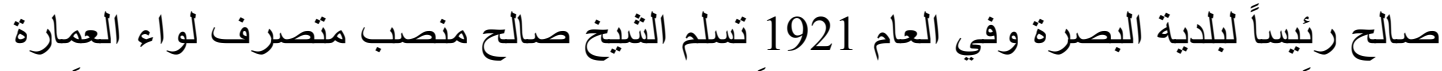

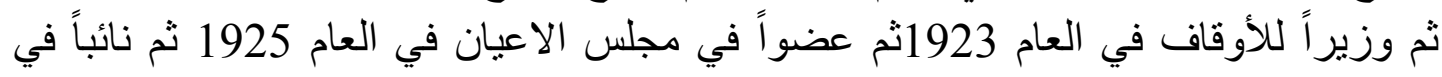

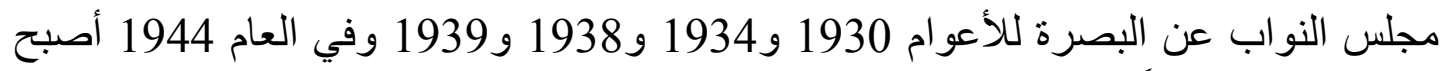

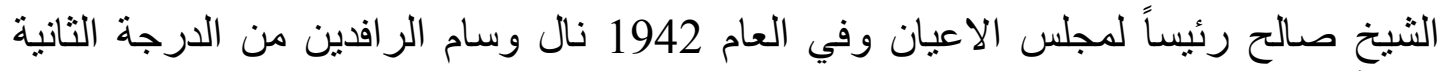

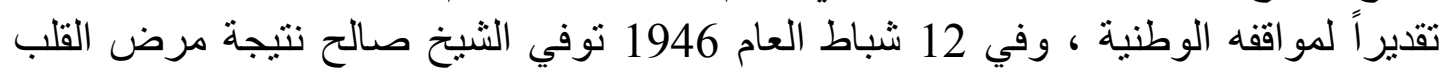

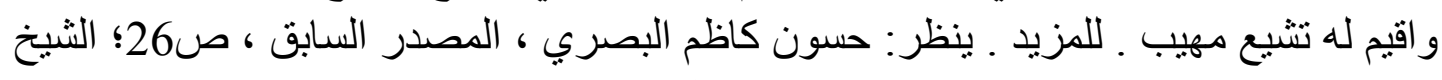

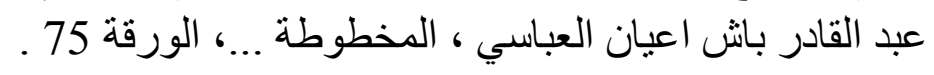

(1) ينظر : الثيخ عبد القادر باش اعيان العباسي المخطوطة ...، الورقة 74. 


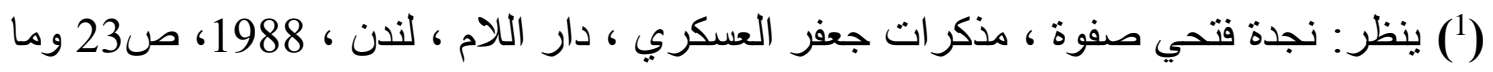

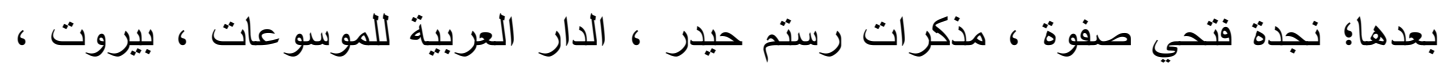

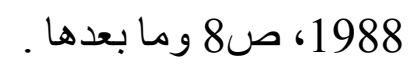

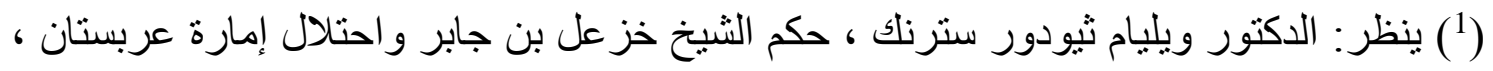

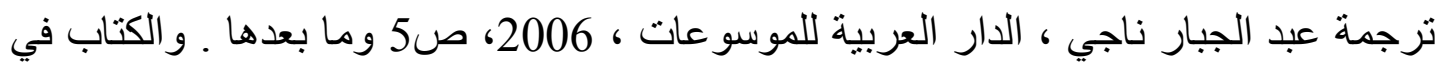
الاصل أطروحة دكتور اهي .

(1) عصبة الأمم: أول منظمة عالمية أنشأت للحفاظ على الامن و السلم الدوليين وهي من ثمار

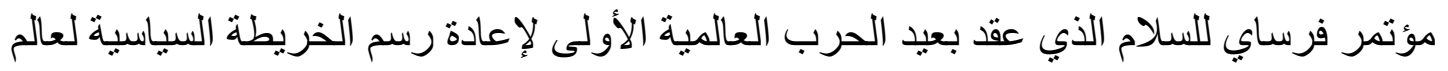

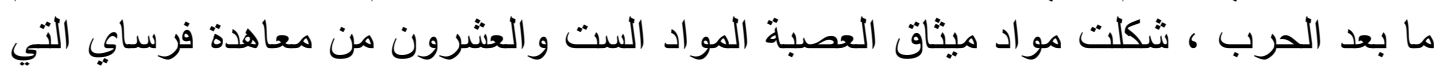

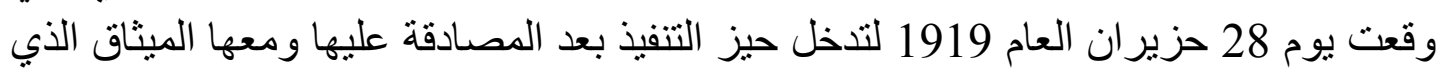

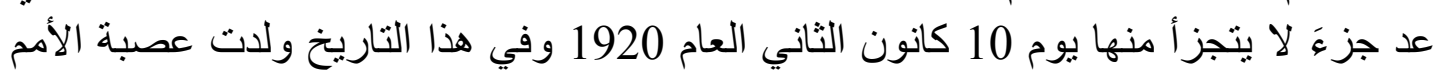

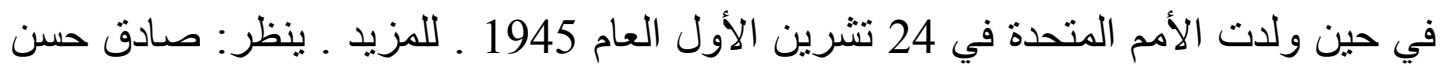

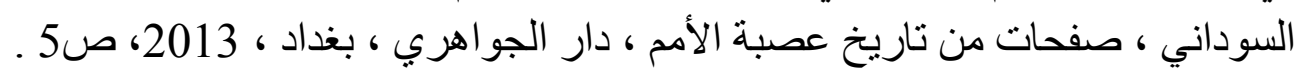

(1) على الرغم من النضال الذي خاضه الشعب العر اقي ضد السيطرة البريطانية المباشرة وتتويج

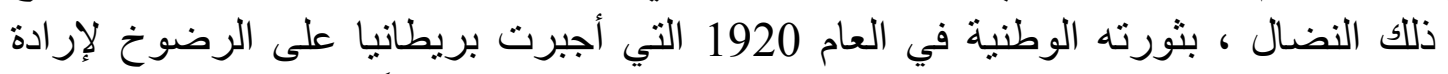

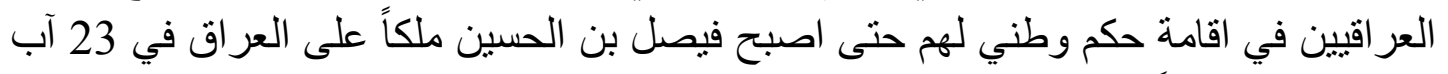

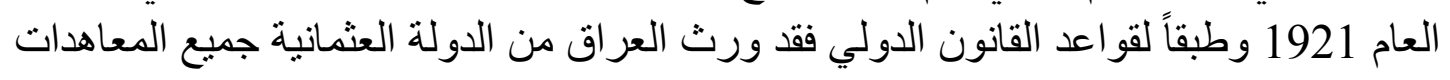

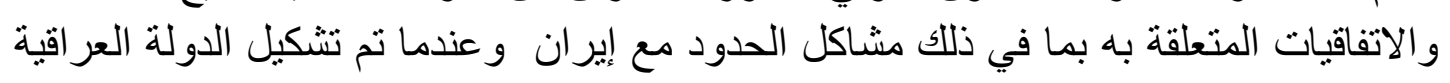

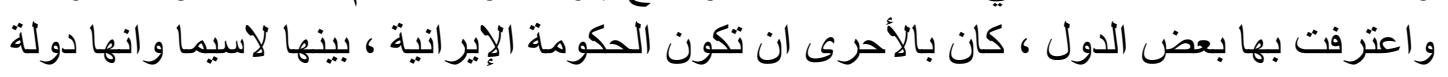

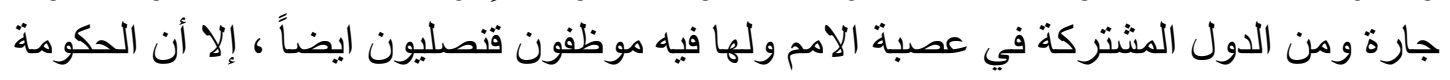

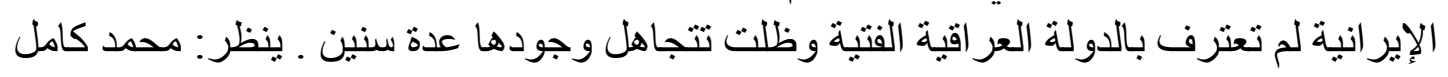

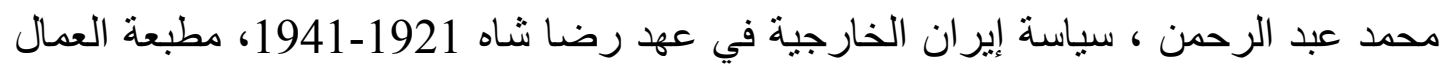

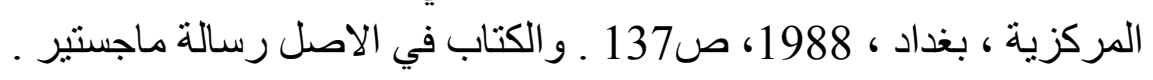

(1) يلفظ الإير انيون الحاء العربي بـ هاء وهذا يعود للتباين والاختلاف في اللفظ بين اللغتين

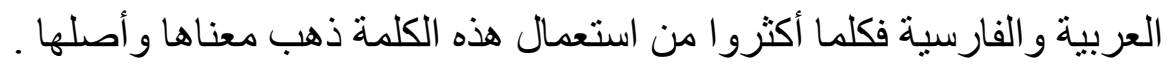

(1) ينظر : كريم محمد صالح محمد المشهداني ، سياسة بريطانيا تجاه الأحواز 1881-1925،

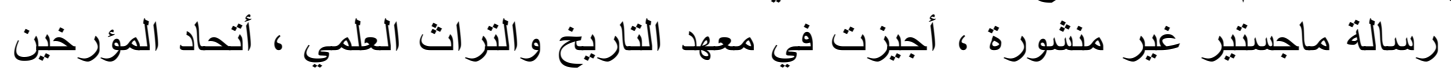
العرب ، بغداد ، 2011، ص6؛ عباس خضير عباس ، الاحواز عربية ، بغداد ، 1973، 
(1) بنظر : كريم محمد صالح محمد المشهداني ، المصدر نفسه ، ص6

(1) ينظر:علي جاسب عزيز الصرخي ، تاريخ الحركة الوطنية في الاحواز 1925-1956، رسالة

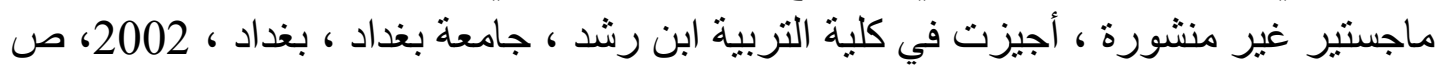

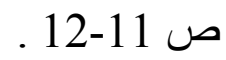

(1) خوزستان: لفظة مكونة من مقطعين وهما " الخوز " وهم أقوام سكنوا الإقليم قبل الإسلام

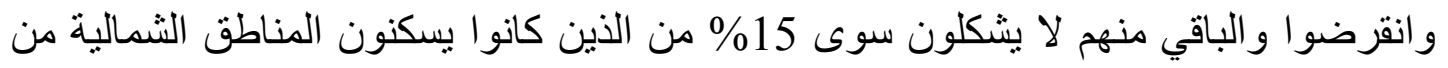

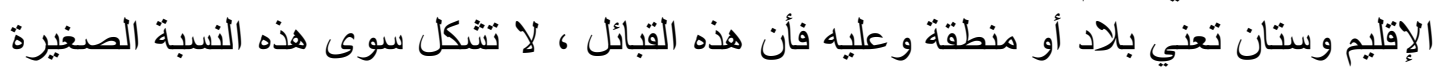

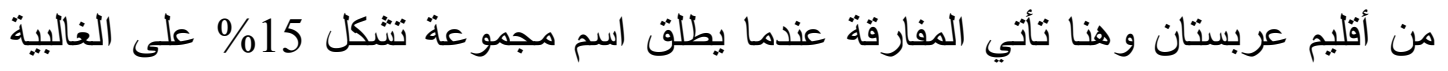
الباقية التي تشكل 80\% من السكان ودون أدنى شك فأن تسمية خوزستان هي تسمية طارئة

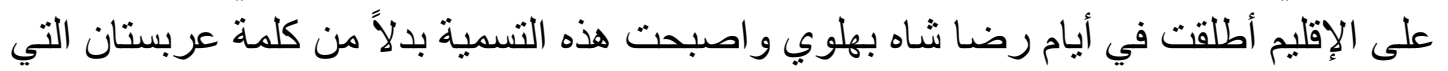

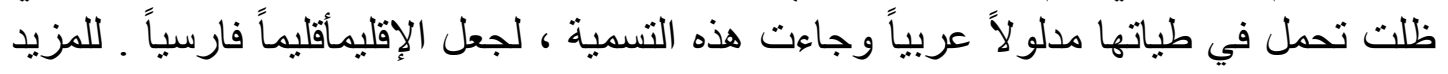

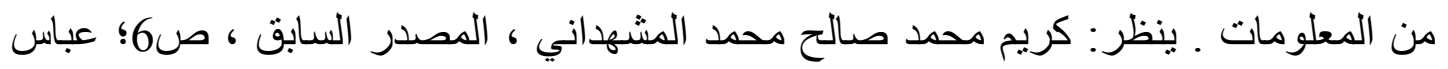

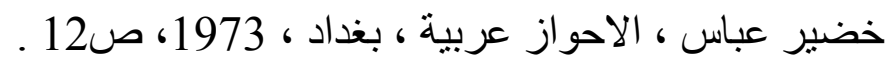

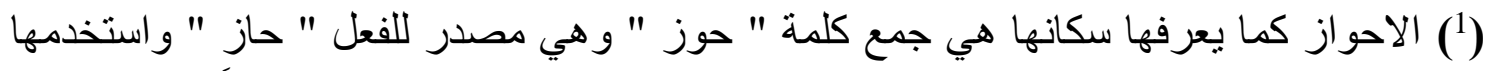

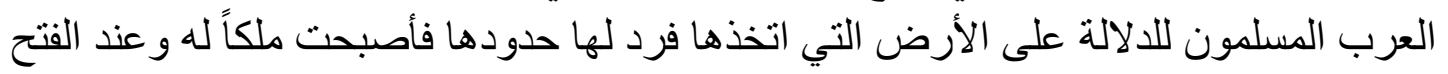

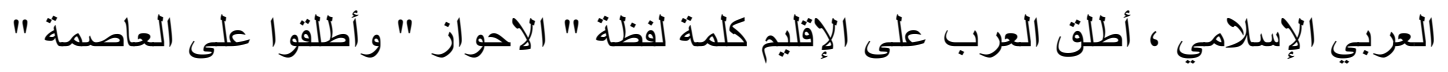

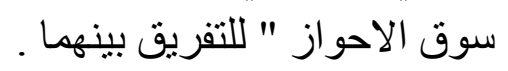

(1) ينظر : كريم محمد صالح محمد المشهداني ، المصدر السابق ، ص7 .

(1) : يؤلف مجموع السكان في الاحواز حسب احصاء العام 1998 نسبة 9 \% من مجموع سكان

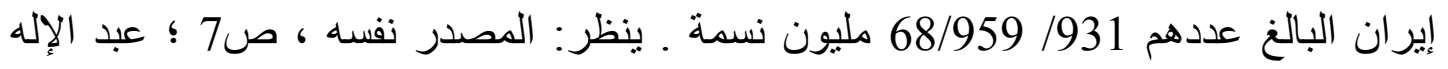

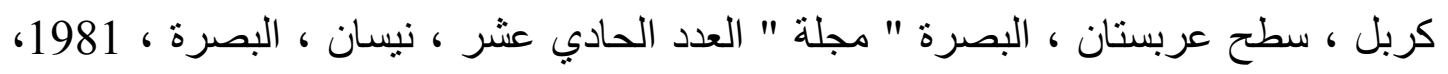

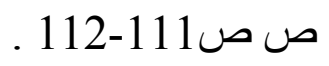

(1) رضا بن عباس بن علي قلي خـان داداش المازندر اني ولد في مكان يسمى آلثـت في منطقة سو ادكوه الواقعة شمال مقاطعة مازندر ان على بحر قزوين في 16 آذار العام 1878 كان جده لأبيه و اسمه مر اد علي خان برتبة رائد في جيش فتح علي شاه وتوفي خلال الحملة الانكليزيـة على إيران في العام 1857 أما و الده عباس قلي خان فكان جندياً عادياً في الجيش وقد توفي ولم ييلغ رضنا الثهرين من عمرهو ومنذ ذلك الوقت تكفلت والدته القققاسية الاصل به حيث نشـأ 
رضا بقية عمره في كنف خاله المسمى أبو القاسم الذي كان يعمل ضـابطاً صـغيراً وهو الذي أدخل رضا في الجيش الإير اني وكان في بداية الامر في سلك المثـاة في العام 1900و عندما جلب مظفر الدين شـاه المدافع الرشاثة التحق رضا في فرقة الرشاشـات في بداية الامـر برتبـة جندي ثم ارتقى ليصبح رئيس عرفاء ثم التحق بعد مدة بفرقة القوز اق واستطاع بقيادته لها بعد أن عمت الفوضى و الفساد عموم مفاصل الدولة القاجارية في العام 1920، ان يقوم رضـا خـان بانقلابه في 21 شباط العام 1921المعروف بأنقلاب " حوت " فعين وزير اً للدفاع ثم رئيس للوزر اء في العام 1922 وفي 31 تشـرين الأول العـام 1925 أعلن البرلمـان الإيراني بأغلبيـة

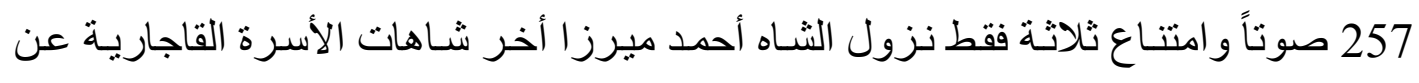
العرش وقدم البرلمان التاج لصاحب الترجمة الذي توج شاهاً جديداً في حفل مهيب جرى في قصر كلستان في 25 نيسان العام 1926وبذلك انتهى حكم الاسرة القاجارية في إير ان ، إلا أن الثـاه رضا خان بهلوي عزل في 16 أيلول العام 1941 عن العرش بدعوى عدم التعاون مـع الحلفاء في الحرب العالمية الثانية حيث أبعد إلى جزيرة موريس وبها توفي في العـام 1944 ونقل جثمانه إلى القاهرة ومن ثم إلى طهر ان في العام 1947 ـ للمزيد ـ ينظر : رضـا شـاه ، المـذكرات ، ترجمـة علـي البصـري ، بغـداد ، 1950، ص17 ؛ كـارل بروكلمـان ، تـاريخ الثعوب الاسلامية ، نقله للعربية نبيه امين ومنير بعلبكي ، ط3، بيروت ، 1961، ص131؛ سـليم واكيم ، إيـر ان في الحضـارة ، بيـروت ، 1971، ص1261 ؛ أحمــ عطيـة ، القـاموس السياسي ، ط3، دار النهضة العربية ، القاهرة ، 1968، ص566 ؛ خضير البديري ، التاريخ المعاصـر لإيـر ان وتركيـا ، العـارف للمطبوعـات ، بيـروت ، 2015، ص101 ؛ آل. لـى. الولساتن، رضا شاه كبير و اير ان نو، ترجمـة، عبد العظيم صبوري، (تهران: جاب اوفست محمد على علمى، 1333ش)؛ عبد الله امير طهماسبى، تـاريخ شاهنشـاهى رضـا شـاه بهلوى، جاب دوم، (تهران دانشكَاه تهران، بى نا) .

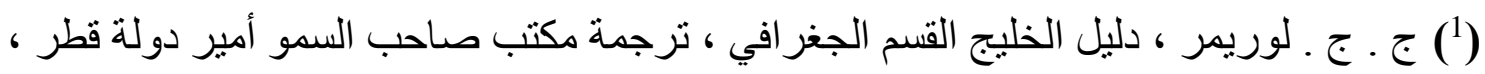

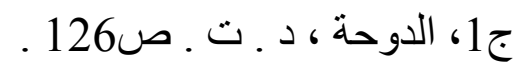




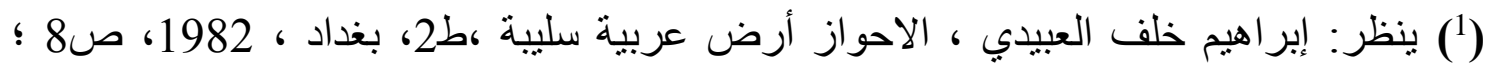

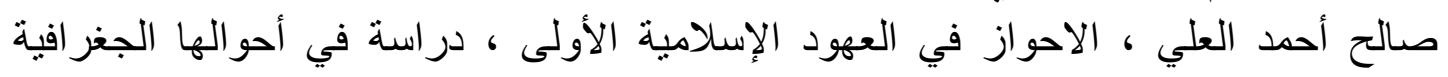

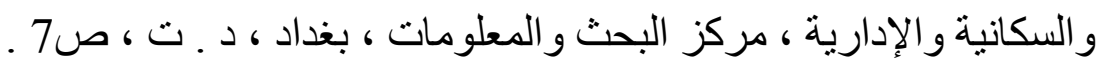

(1) المحمرة: اصل المدينة خار اكس التي انشأها الاسكندر المقدوني وكانت خار اكس كما يقول

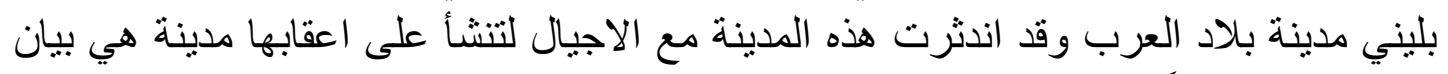

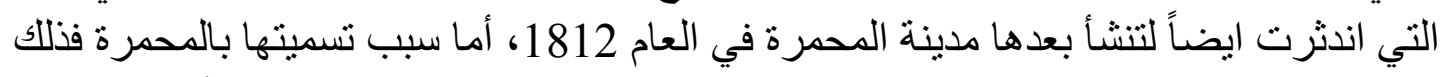

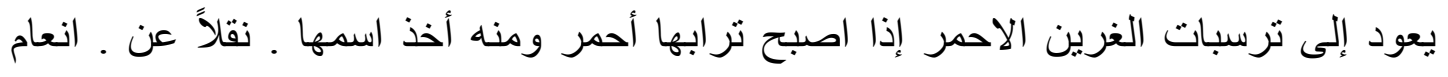

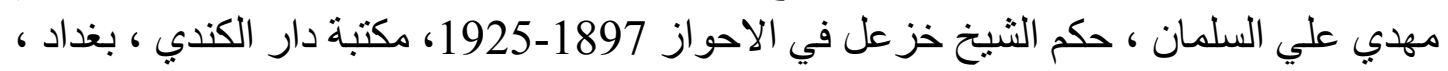

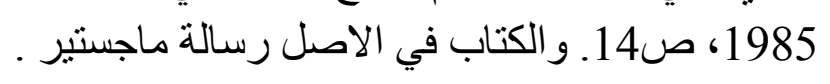

(1) الحويزة: تصغير الحوزة وأصلها من حاز بحوز حوزاً وسميت بهذا الاسم نسبة إلى دبيس بن

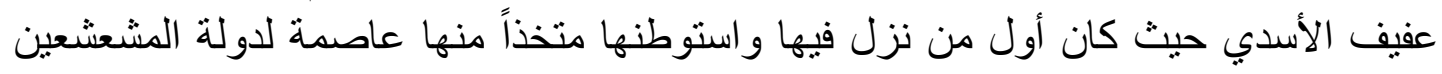

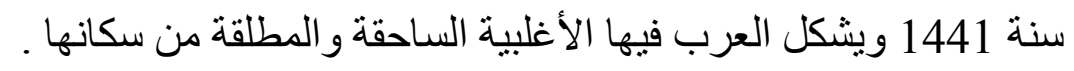

(1) عبادان: سميت عبادان نسبة إلى عباد بن الحصين و هو أول من نزل فيها من المسلمين في عهد

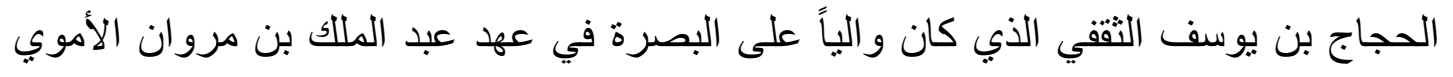
ويشكل العرب نسبة كبيرة من سكانها وينتمون إلى بطن دريس وهم عرب من قبيلة كعب في في .

(1) تستر: اهم مدن الاحواز القديمة ويطلق عليها الفرس اسم شوشتر وتعني بالفارسية المدينة

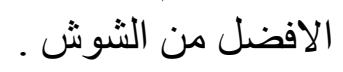

(1) ينظر : كريم محمد صالح محمد المشهداني ، المصدر السابق ، ص13 ؛ منذر عبد الكريم البكر

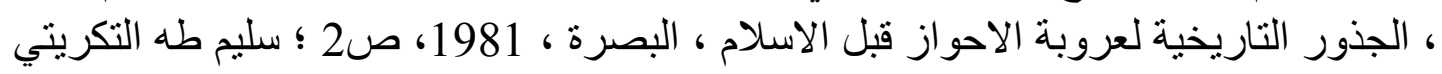

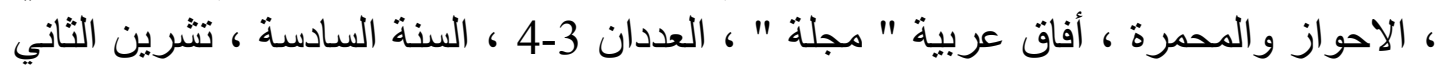

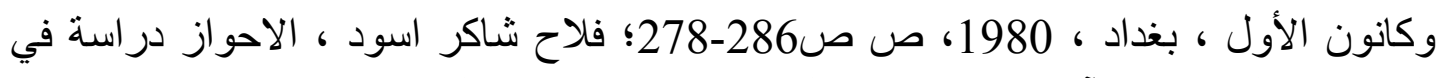

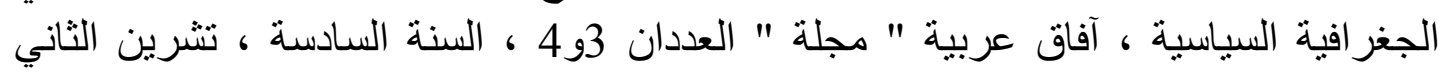

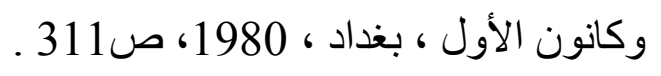

(1) ينظر: انعام مهدي علي السلمان ، المصدر السابق ، ص145 ـ

(1) الحاج محمد علي البهبهاني: شيخ التجار في المحمرة ويتمتع بشخصية قوية وكان وزيراً للشيخ

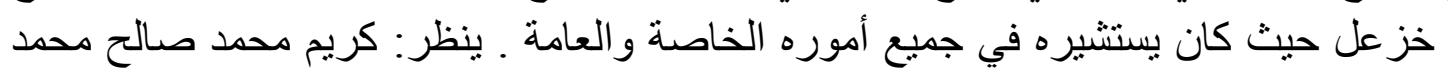

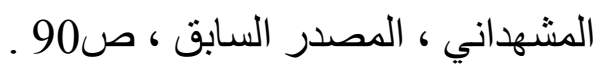




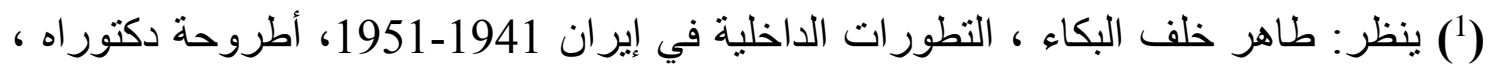

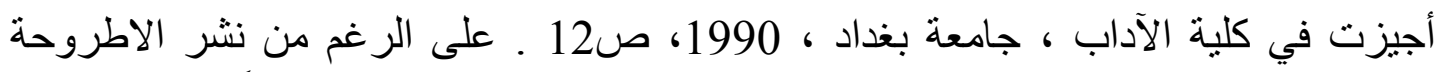

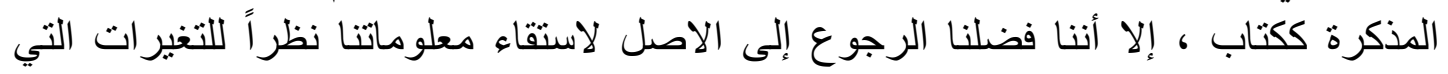

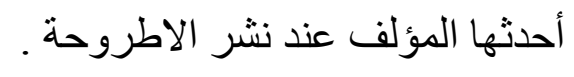

(1) وفي 28 تشرين الأول العام 1923 وبعد استقالة وزارة مشير الدولة تولى رضا خان بهلوي

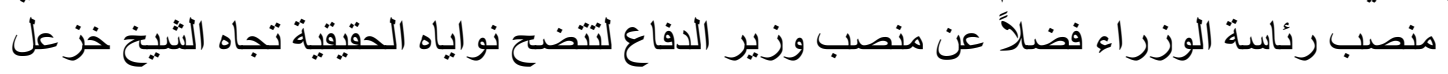

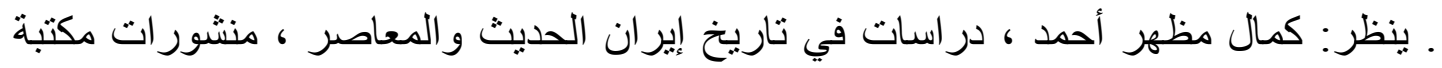

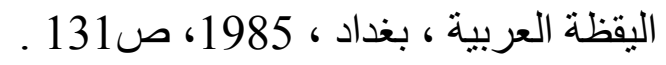

(1) في بداية الأمر بدأت العلاقات بين الشيخ خزعل ورضا خان تشير بشكل حسن حتى أن الثيخ

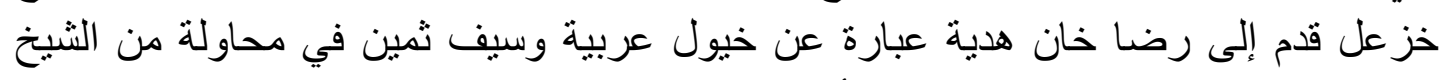

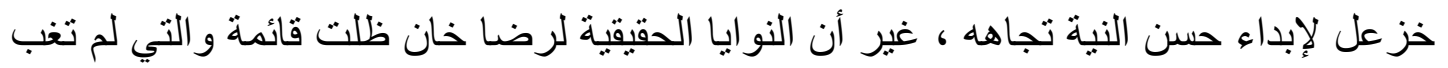

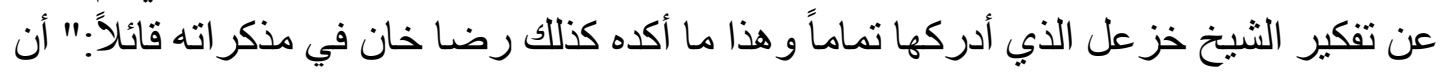

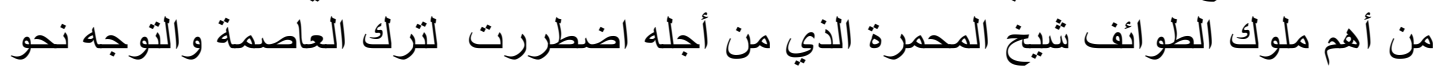
الجنوب حيث أصدرت أمري بإعادة الأمن والاستقرار في جنوب فارس الفي كما أعدته إلى شماله

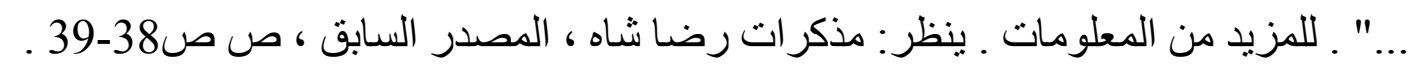

(1) ينظر : الثيخ عبد القادر باش اعيان العباسي .... المخطوطة ، الورقة 75 .

(1) يعتبر الثيخ خز عل من اكبر مالكي بساتين النخيل في البصرة وخاصة في منطقة ابي الخصيب

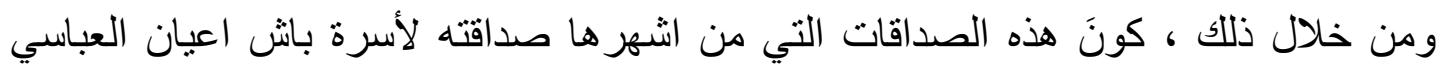

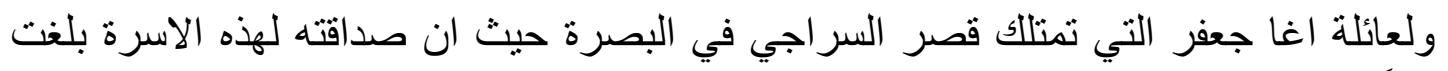

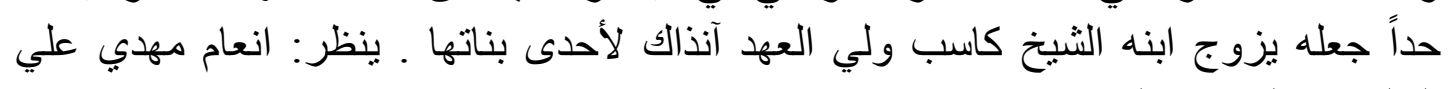
السلمان ، المصدر السابق ، صله جلـ114.

(1) برزت أولى مظاهر التوتر بين الثيخ خز عل وحكومة فارس المركزية في العام 1922 عندما

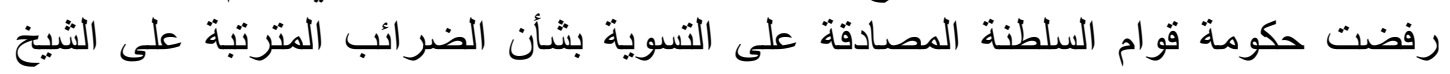
خزعل و التي لم تسدد منذ العام 1913 وقد طالبت الحكومة بتسديد المبلغ المتر اكم والبالغ

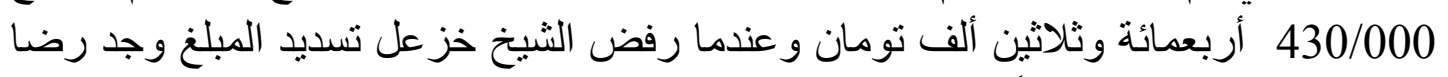

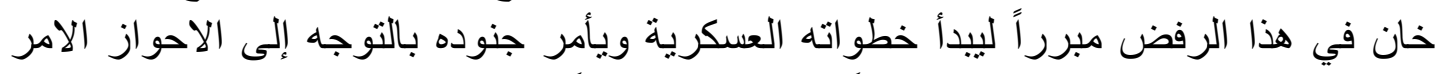

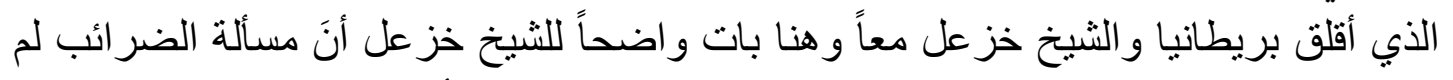

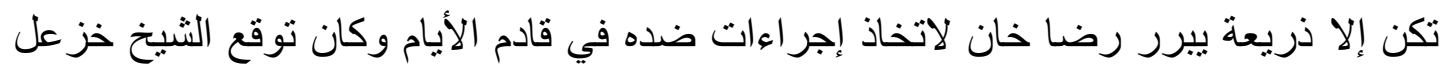


في محله . ينظر : الثيخ عبد القادر بانش اعيان العباسي ، المخطوطة ....، الورقة 75؛ كريم

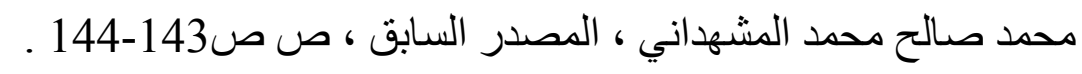

(') ينظر : الثيخ عبد القادر باش اعيان العباسي ، المخطوطة...، الورقة 75 ـ

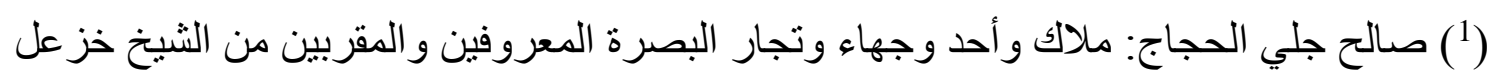

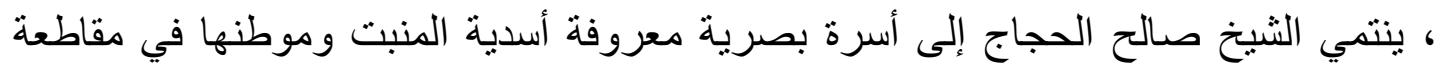

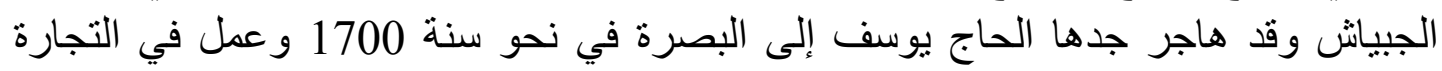

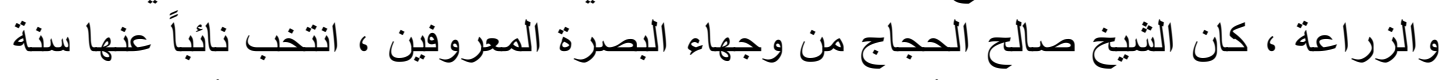

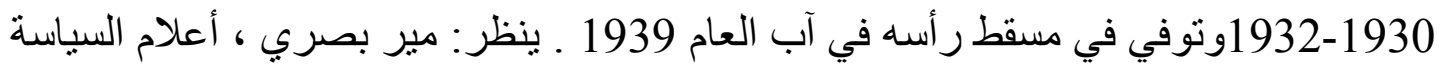

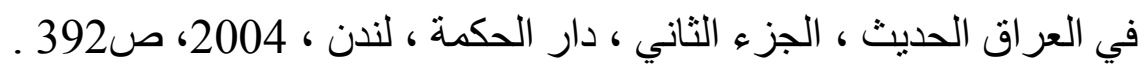

(1) الناصرية: نسبة إلى أول امر اء بني كعب ناصر بن محمد وهي التسمية الاولى لمدينة الاحواز

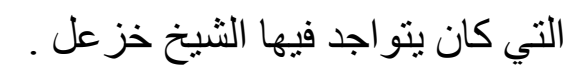

(1) ينظر : الثيخ عبد القادر باش اعيان العباسي ، المخطوطة...، الورقة 75 ـ

(1) جعفر العسكري: ولد في بغداد في العام 1885 من عائلة عسكرية خدمت مع الجيش العثماني

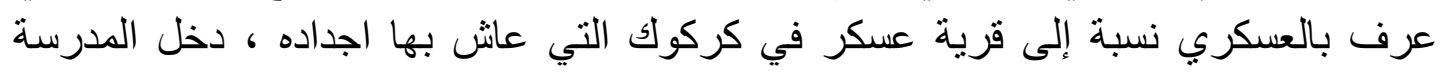

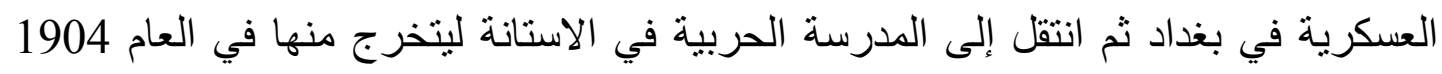

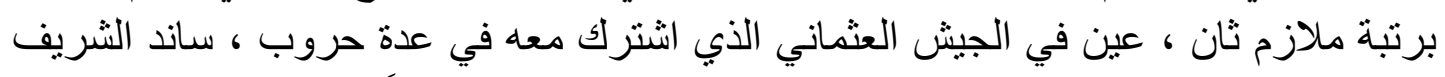

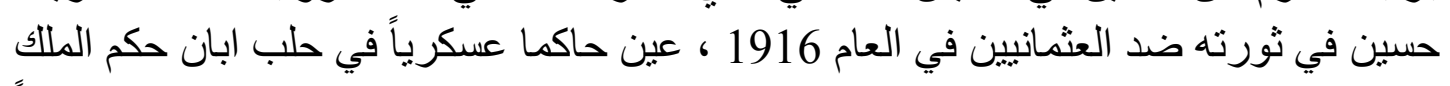

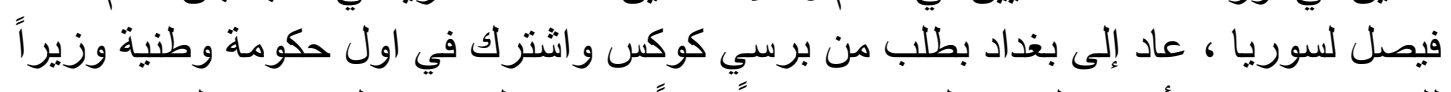

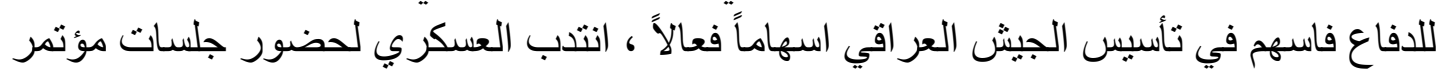

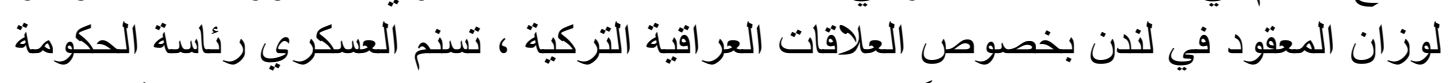

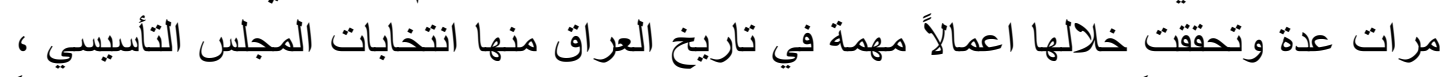

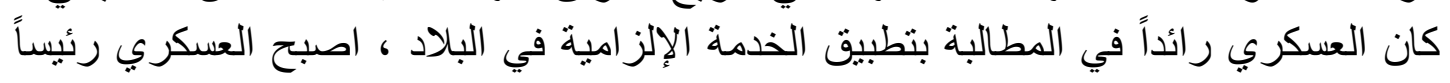

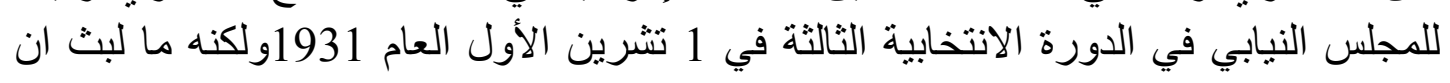

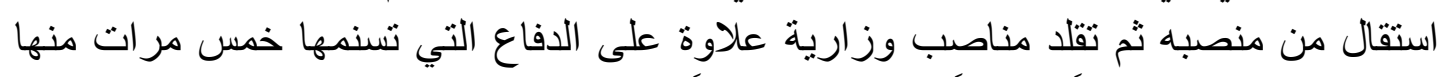

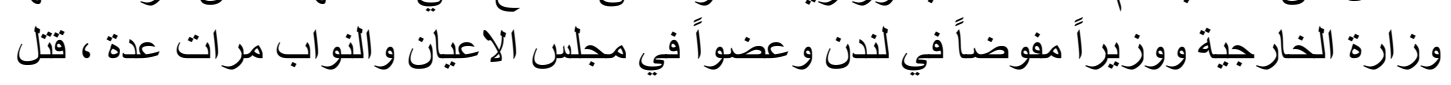

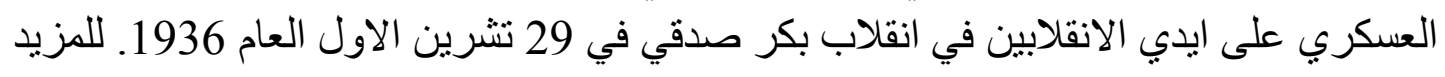

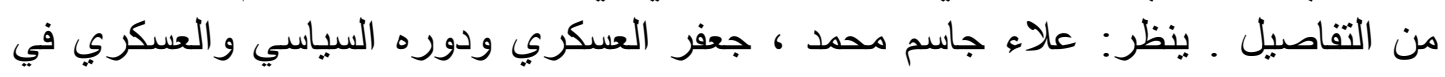

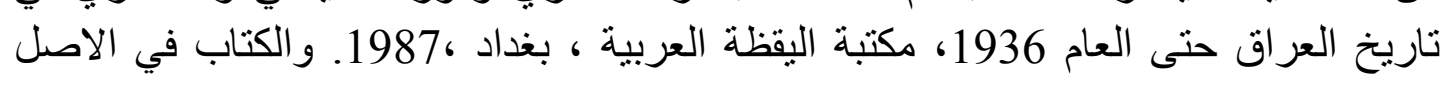
رسالة ماجستير. 
(1) خلال أحدى زيار ات العسكري إلى البصرة ، استضافه الثيخ العباسي و اقام له حفلاً تكريمياً في

(1) ر اسم سردست: من الضباط السورين ولد في دمشق وتخرج من المدرسة الحربية في إسطنبولٍ

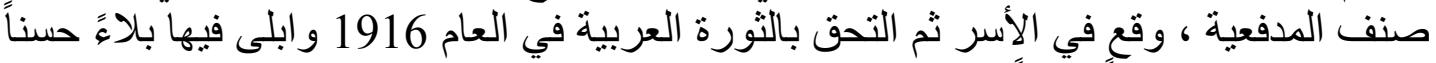

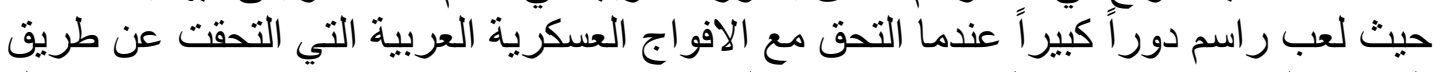

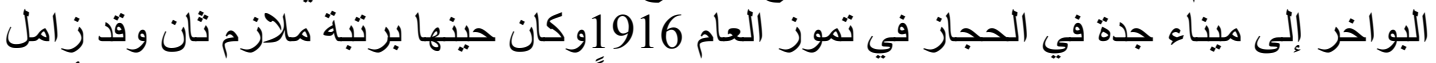

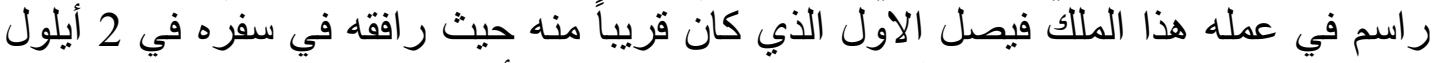

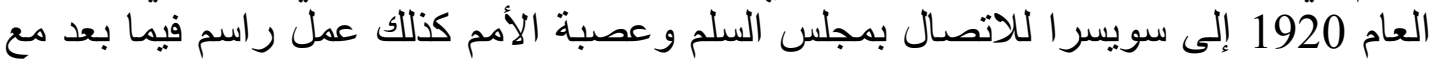

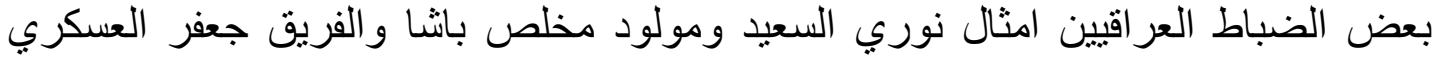

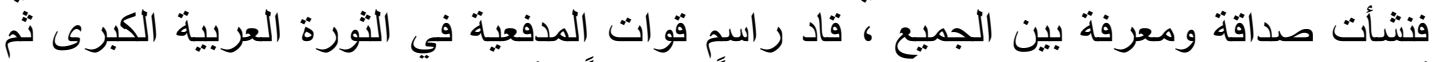

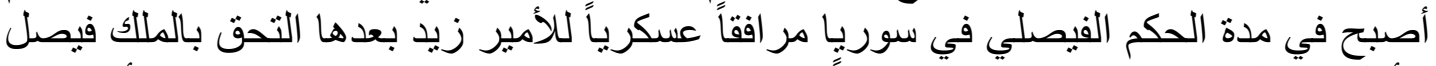

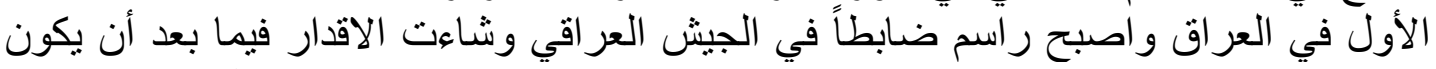

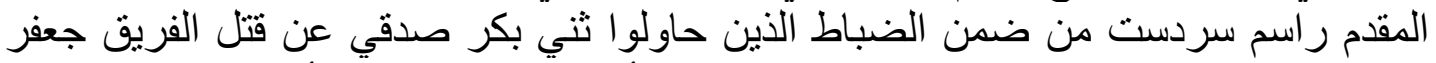

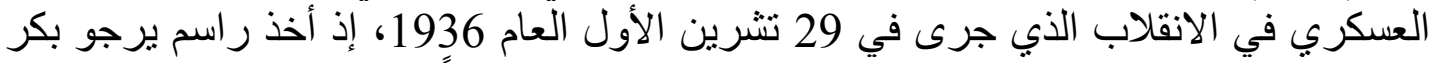

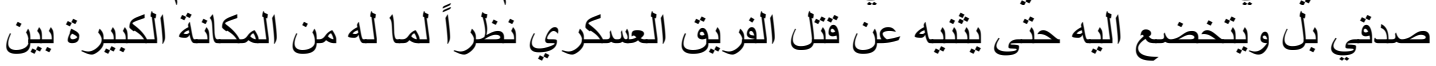

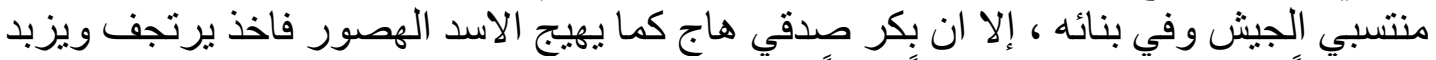

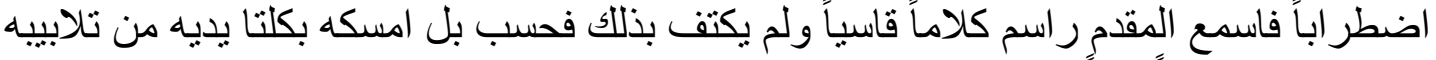

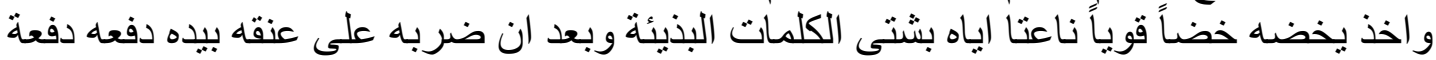

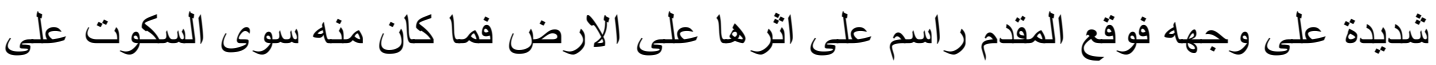

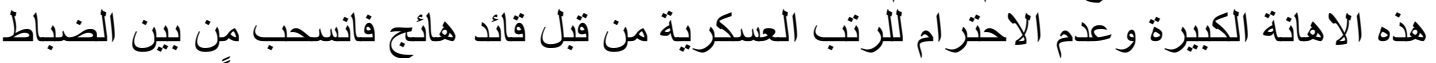

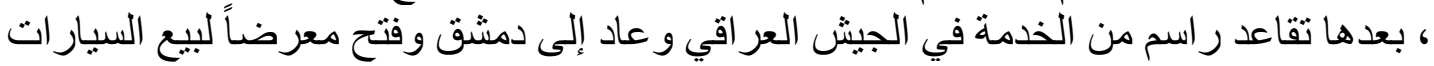

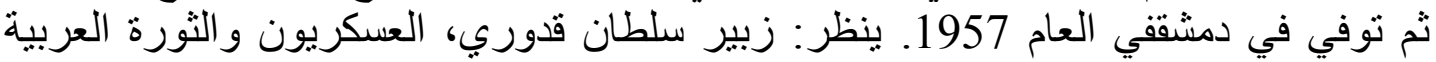

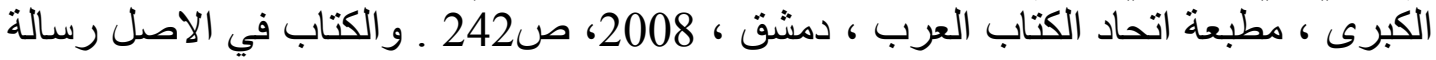
ماجستير ؛ نجدة فتحي صفوة ، مذكرات جعفر العسكري ، المصدر السابق ، ص ص ص109-

(1) ينظر: الثيخ عبد القادر باش اعيان العباسي ، المخطوطة....، الورقة 76 .

(1).ينظر: الثيخ عبد القادر باش اعيان العباسي ، المخطوطة ....، الورقة 76 . (1) (1) ينظر: المصدر نفسه.... الورقة 76 . (1) (1) ينظر: المصدر نفسه..، الورقة 76 . (1) ينظر : تللك الدعو ات في الملحق المرفق . (1) ينظر : الثيخ عبد القادر باش اعيان العباسي ، المخطوطة ....، الورقة 76 . 
(1) نوري السعيد: ابن محاسب موصلي كردي المولد تركي الثقافة عر اقي المهنة ولد في منطقة " تبةالكاوور " تل النصارى قرب ساحة الميدان في بغداد في العام 1888 ونشأ في عائلة بغدادية

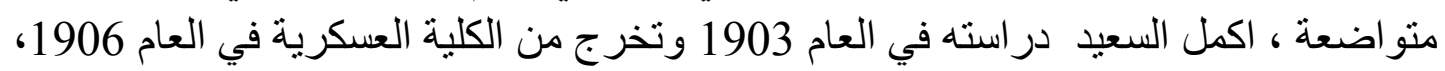

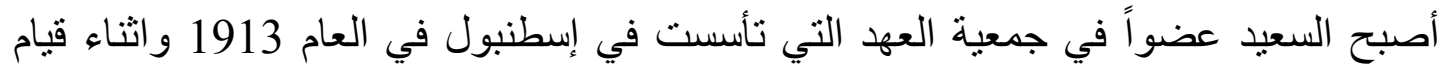

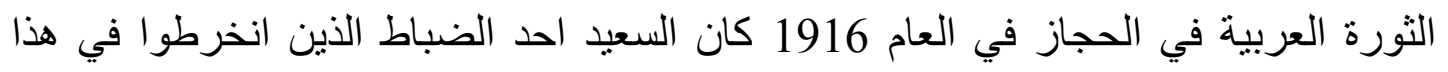
الجيش ، برز دوره بشكل كبير بعد تكوين الحكم الوطني في العراق في 23 آب العام 1921

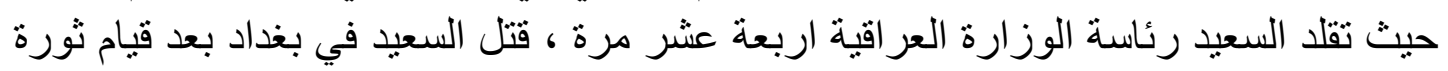

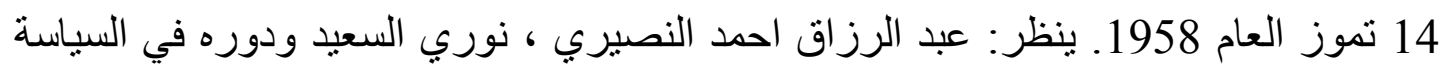

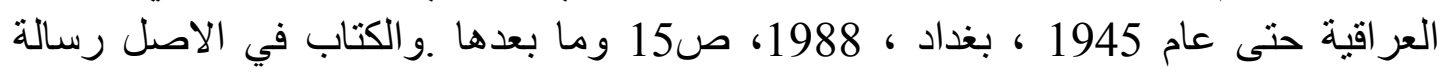
ماجستير . معرله

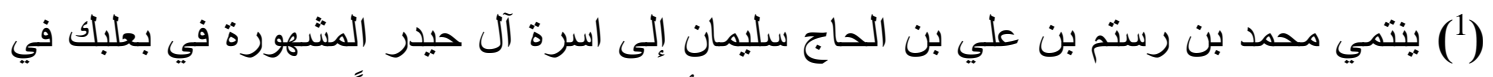

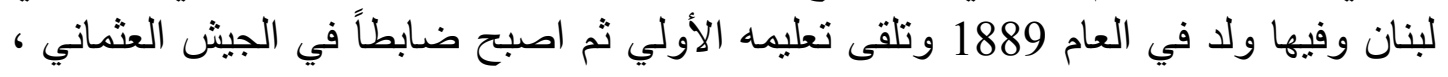

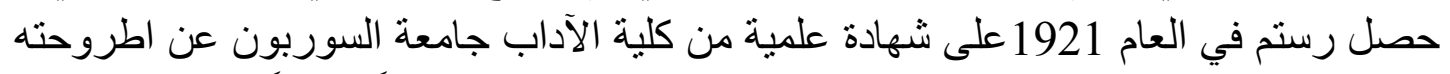

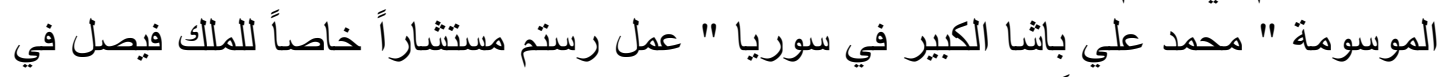

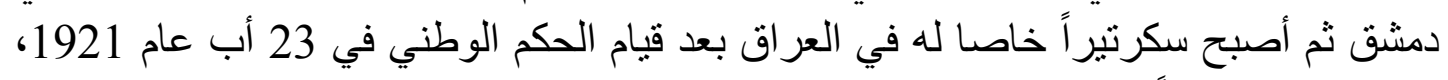

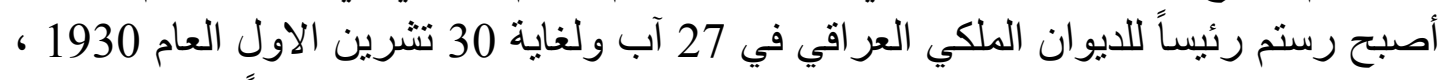

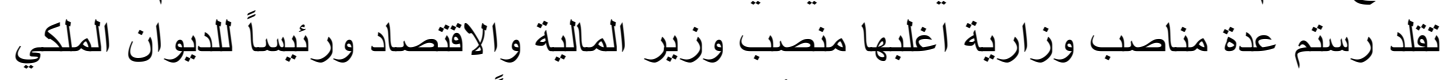

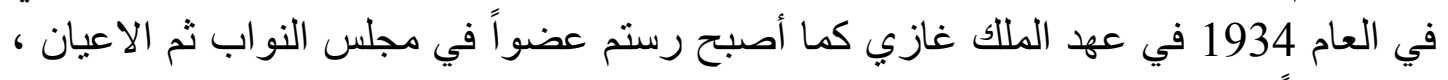

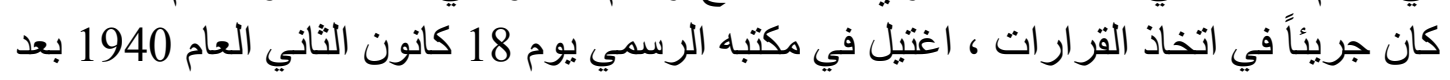
أطلاق الرصاص جليه من قبل مفوض الثرطة حسين فوزي توفيق وقيل ان عملية الأغتيال

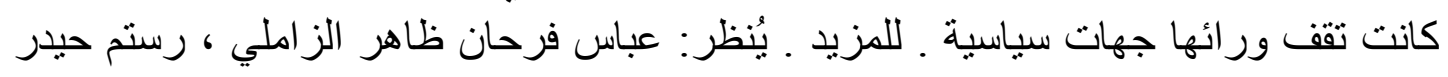

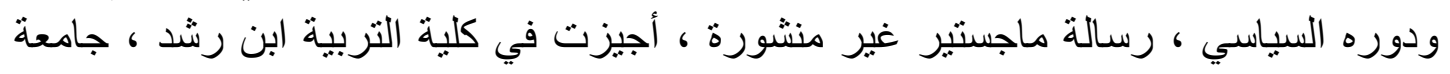

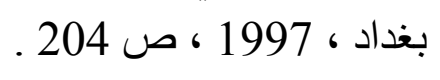

(1) بدأت علاقات الثيخ خزعل مع رضا خان تميل نحو التوتر ، بعد استقالة وزارة مشير الدولة

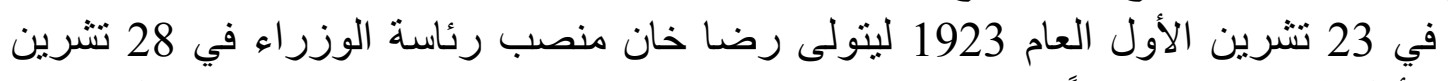

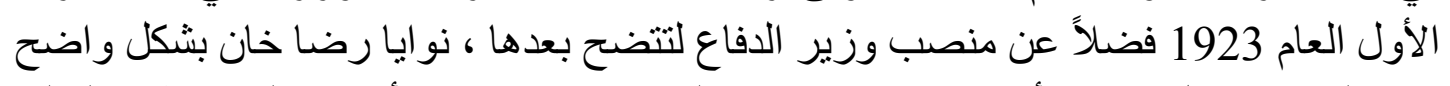

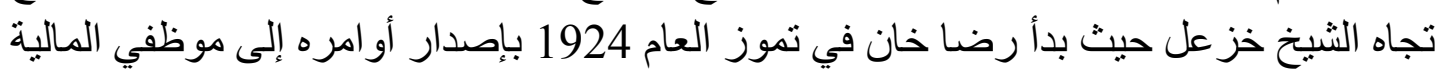

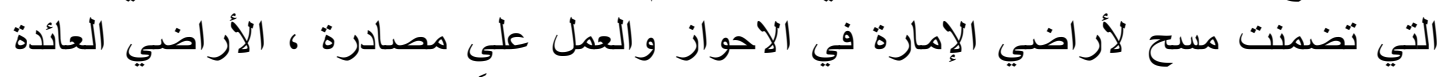

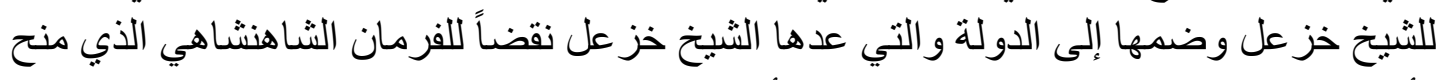
لأبيه في العام 1857 وكذلك الفرمان الذي أصدره مظفر الدين شاه في العام 1903 ـ للمزيد . 


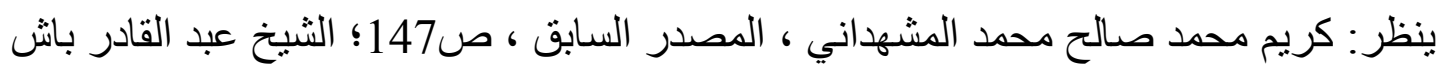
اعيان العباسي ، المخطوطة ...، الورقة 75.

ينظر : المصدر نفسه ، الورقة 75.

( ) ينظر : الثيخ عبد القادر باش اعيان العباسي ، المخطوطة...، الورقة 75 ـ (1)ينظر نص الرسالة في : حسين خلف الثيخ خز عل ، تاريخ الكويت السياسي ، ق1، جـ5، مطبعة

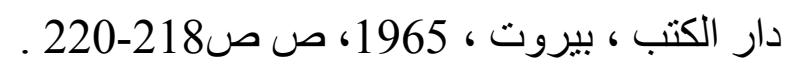

(1) على اعتبار أن سفير نركيا هو سفير لأكبر دولة اسلامية في طهران ـ ينظر: المصدر نفسه ، ص218.

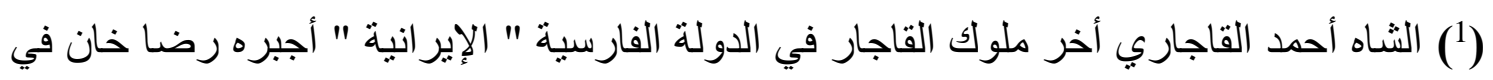

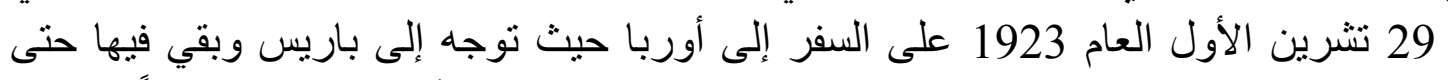

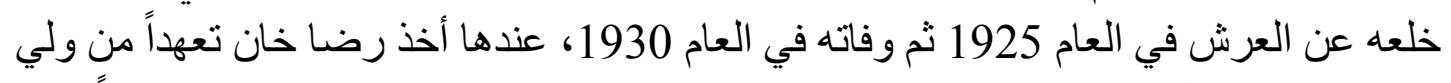

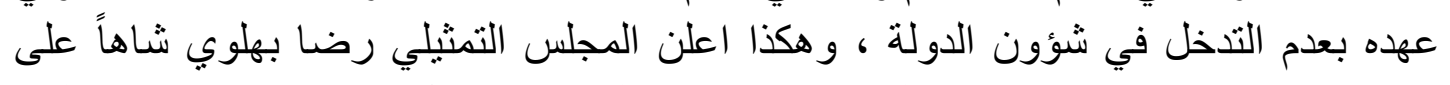

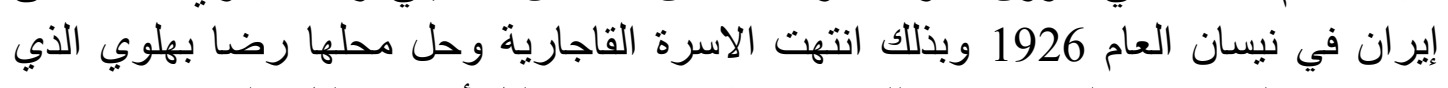

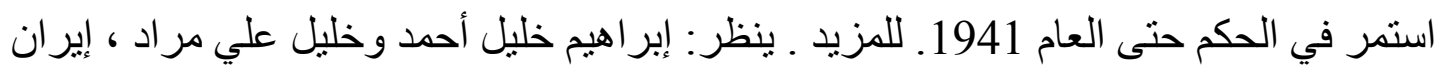

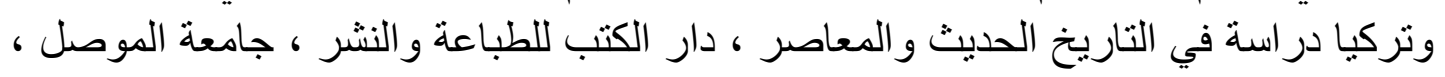

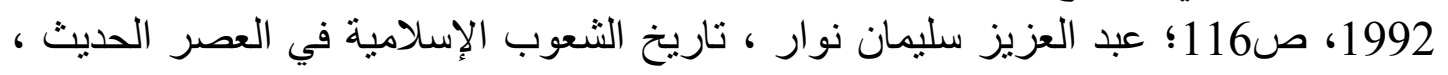

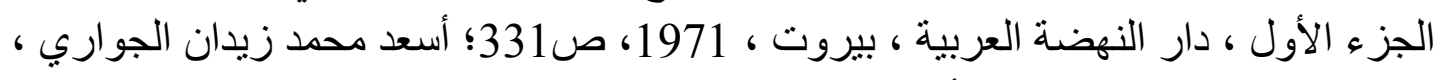

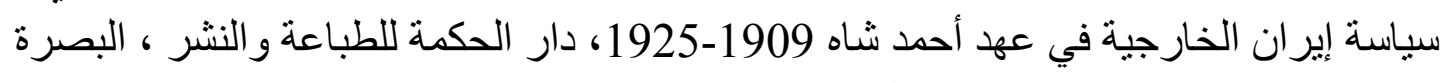

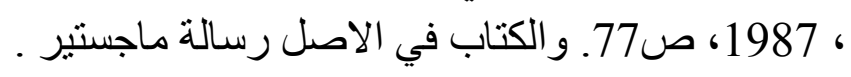

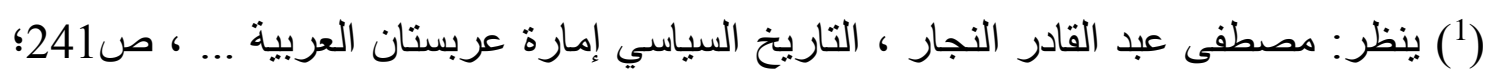

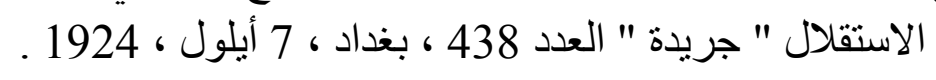
(1) ينظر : حسين خلف الثيخ خز عل ، المصدر السابق ، ص220 .

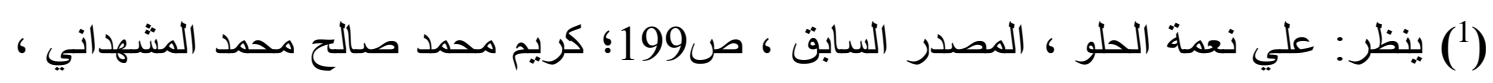

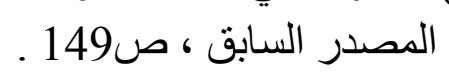

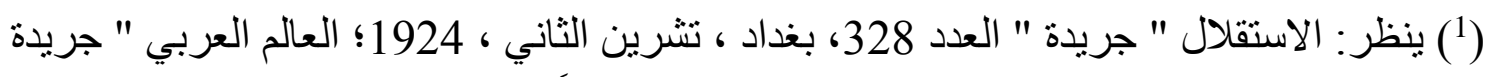

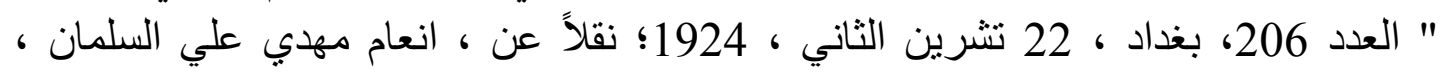

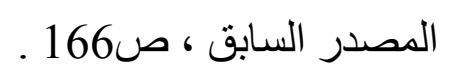


(1) ينظر: علي نعمة الحلو ، المصدر السابق ، ص199؛؛ كريم محمد صالح محمد المشهداني ،

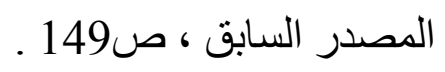

(1) الملا صالح: معتمد شيخ الكويت أحمد الجابر الصباح وقد طلبه الثيخ خزعل لحمل رسالته

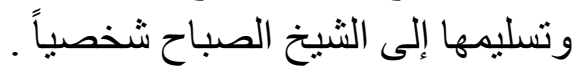

(1) ينظر: مصطفى عبد القادر النجار ، التاريخ السياسي لإمارة عربستان العربية ...، ص241 .

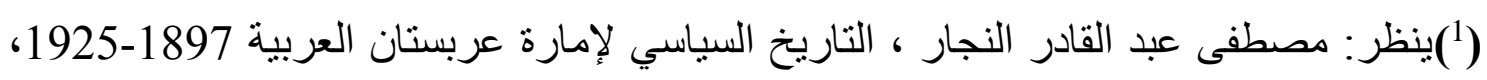

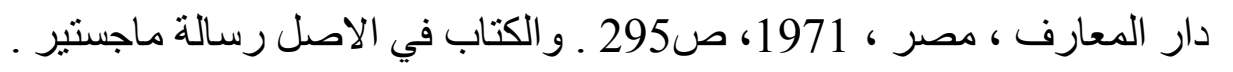

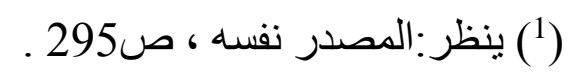

(1) ينظر : حسين خلف الثيخ خزعل ، المصر السابق ، ص231 .

(1) ينظر: المصدر نفسه ، ص199 ؛ جورج لنشوفسكي ، الثرق الأوسط في الشؤون العالمية ،

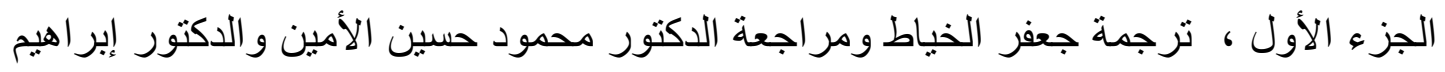

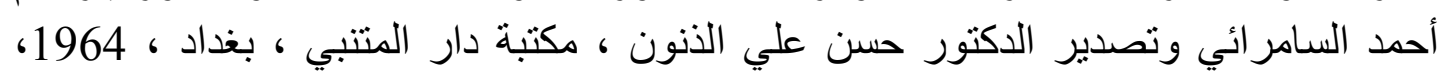
ص 225

(1) ينظر: العراق " جريدة " العدد 1324 ، بغداد ، 14 تشرين الأول ، 1924؛ الأوقات البصرية

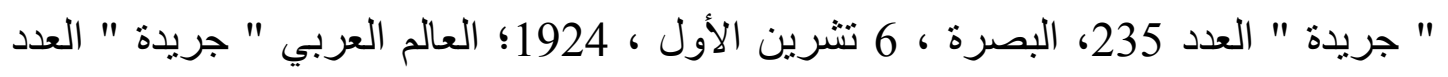

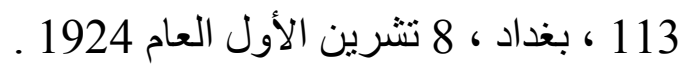

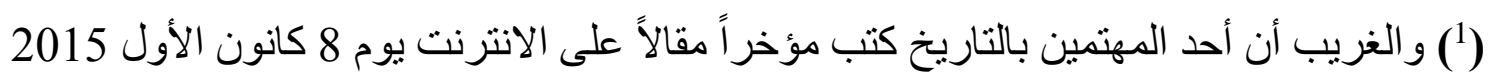

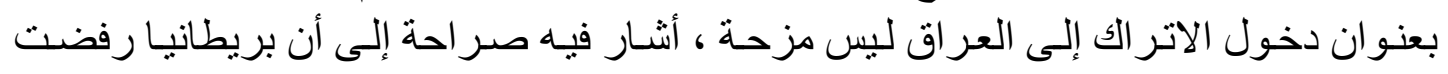

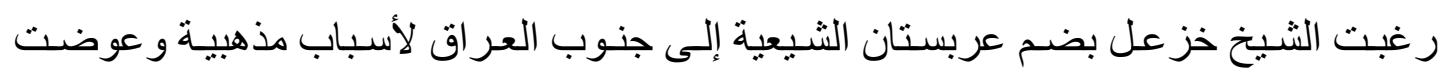

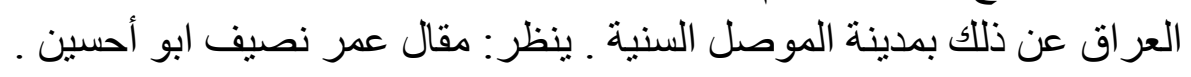

$$
\text { (1) ينظر: المصدر نفسه ، ص ص1989-199 . }
$$

(1) ينظر: مصطفى عبد القادر النجار وفؤاد الراوي ، عربستان الارض الثعب السيادة ، بغداد ،

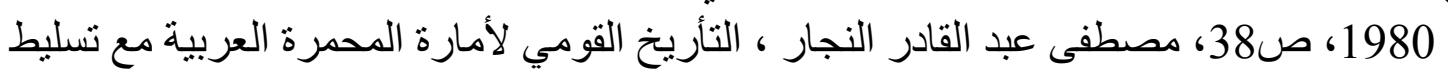

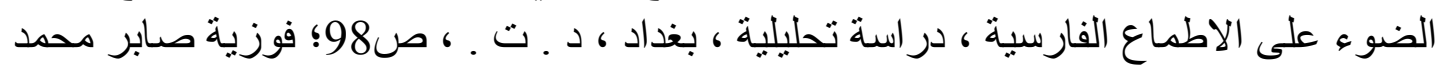

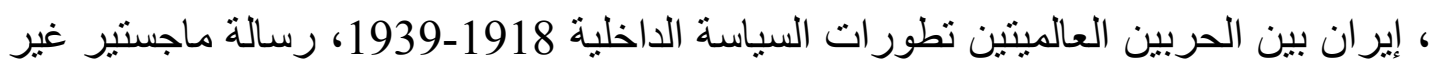

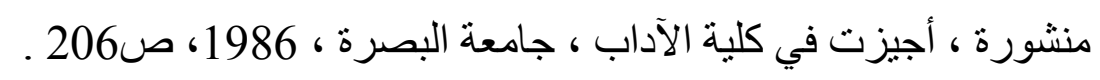




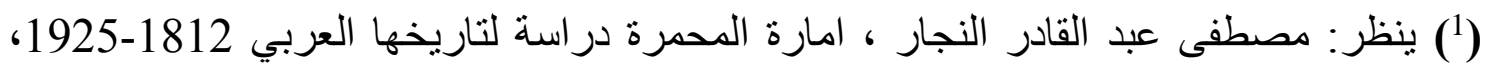

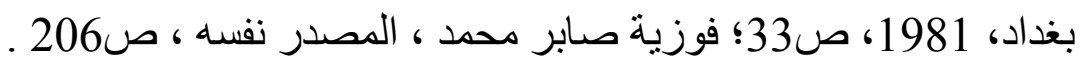

ينظر : فوزية صابر محمد ، المصدر نفسه ، ص206 .

(1) شباب حزب السعادة: حزب أو حلف سياسي شكله وتر أسه الثيخ خزعل في العام 1924 بعد

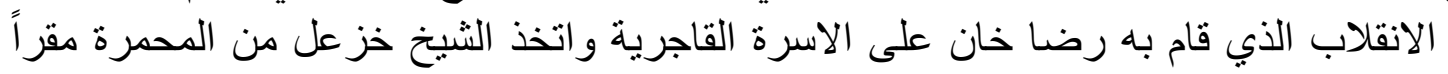

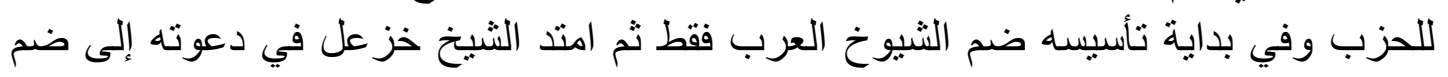

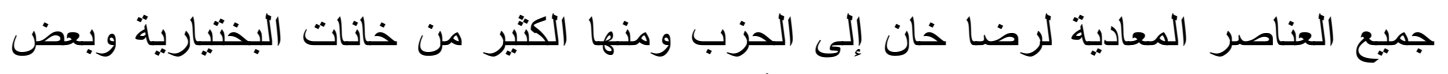

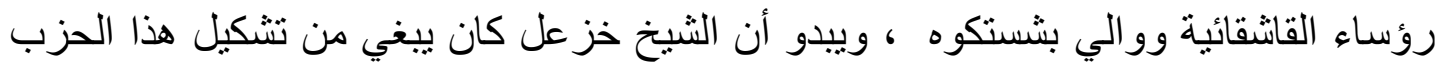

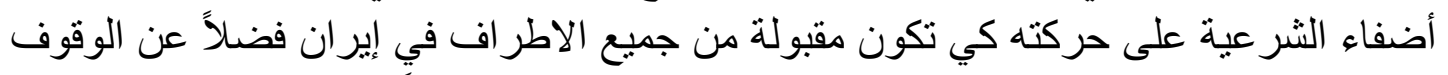

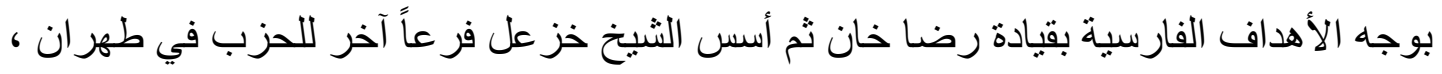

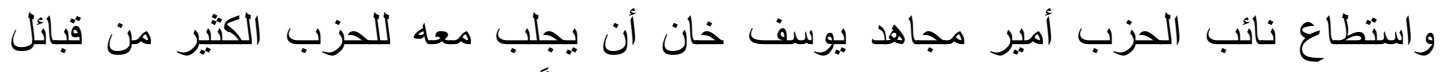

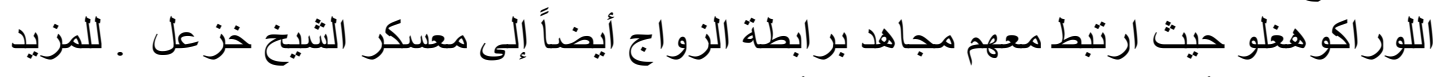

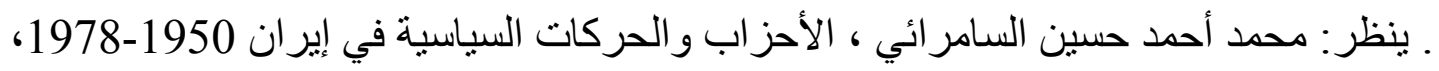

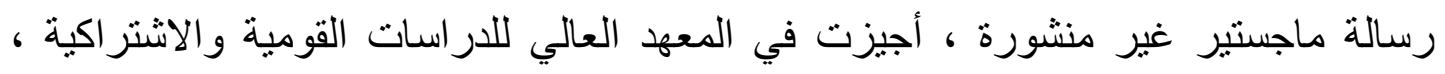

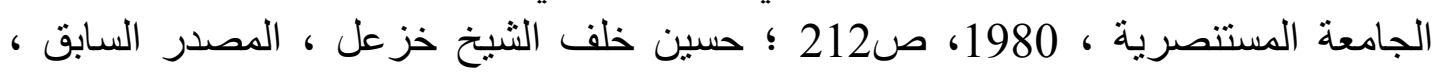
ص217؛ خضير البديري ، التاريخ المعاصر لإيران وتركيا ... ، ص99 ، (1) ينظر: فوزية صابر محمد ، المصدر نفسه ، ص ص205-206 .

(1) لم يكن الثيخ خزعل مطمئناً لباقر خان بسبب تدخلاته في شؤون الإمارة من خلال قيامه

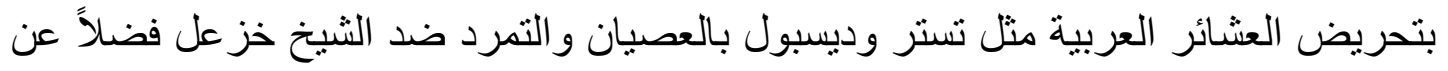

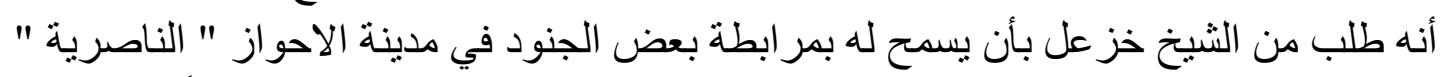

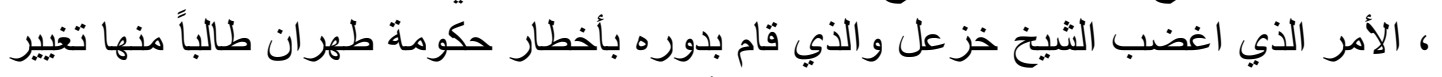

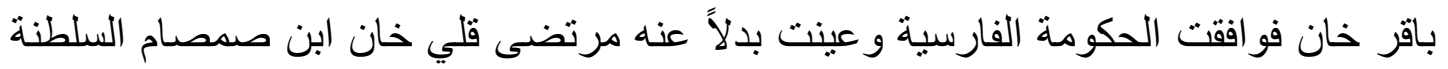

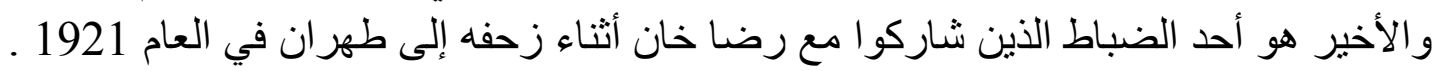
ينظر: عبد الإله بلر الأسدي ، العلاقات البريطانية الإيرانية 1918-1933، أطروحة داطين دكتور اهاه

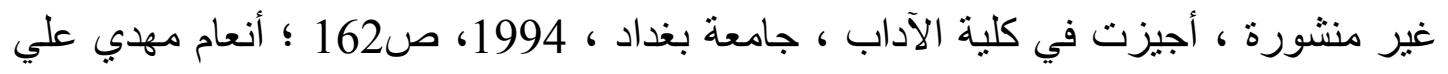

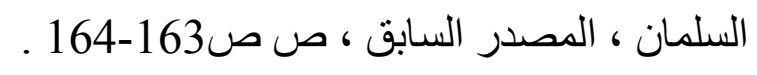

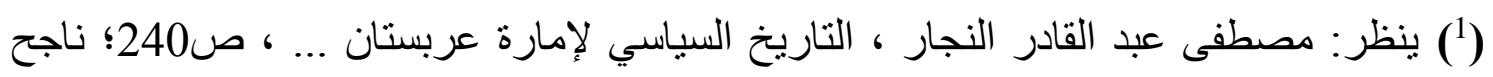

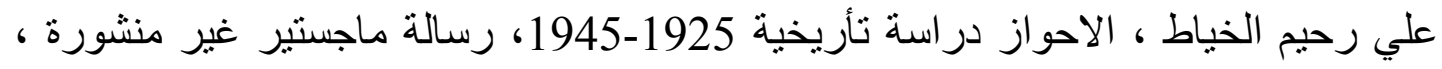

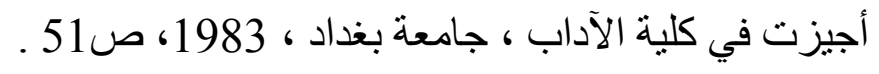




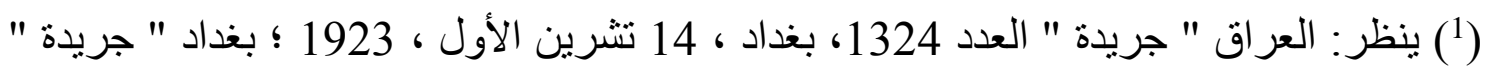

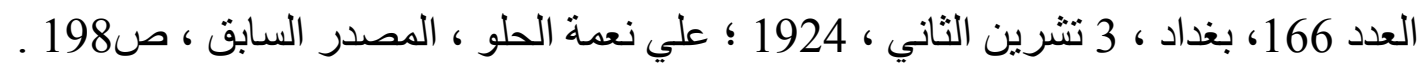

$$
\begin{aligned}
& \text { (1) ينظر: علي نعمة الحلو ، المصدر السابق ، ص198 . } \\
& \text { (1) ينظر : المصدر نفسه ، ص198 . }
\end{aligned}
$$

(1) نقلاً عن ، ويليام ثيودور ستر انك ، المصدر السابق ، ص354 .

(1) هنري روبرت كونويدوبس: Henry Dobbs ايرلندي الأصل بريطاني المولد ولد في العام

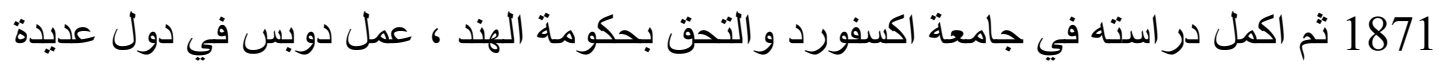

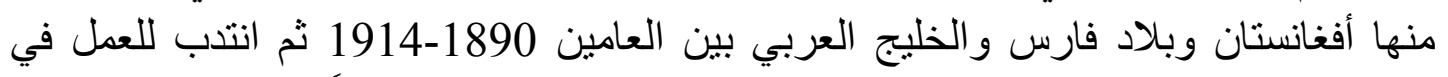

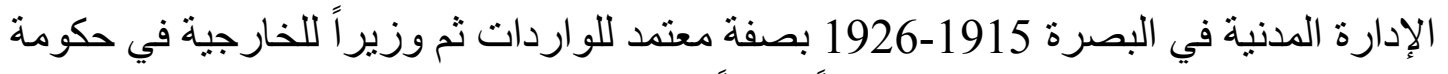

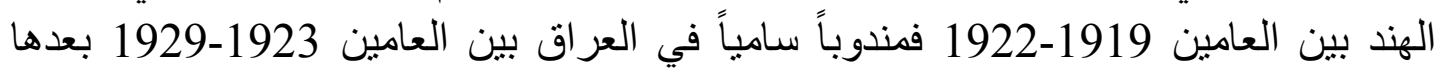

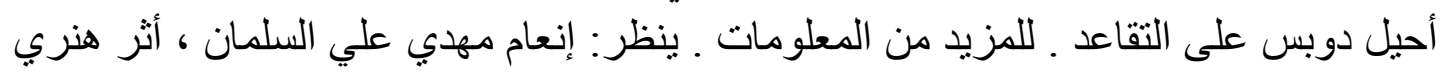

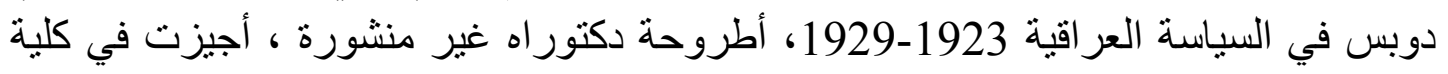

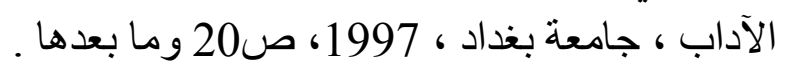

(1) برسي لورينPercy Iorin دبلوماسي بريطاني ولد في لندن في 5 نشرين الثاني العام 1880 نوبن

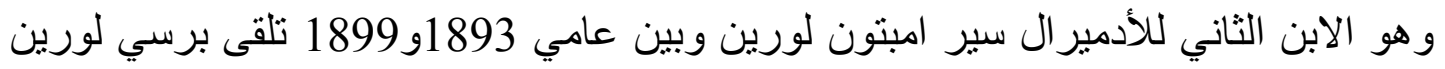

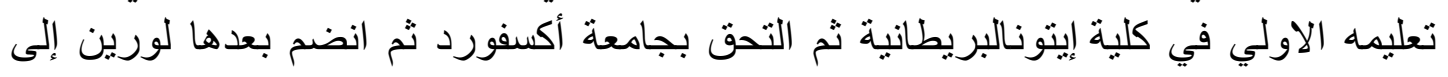
الجيش البريطاني في حرب البوير في جنوب أفريقيا في العام 1899 حتى العام 1902 بعدها

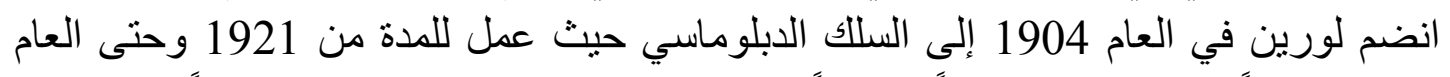

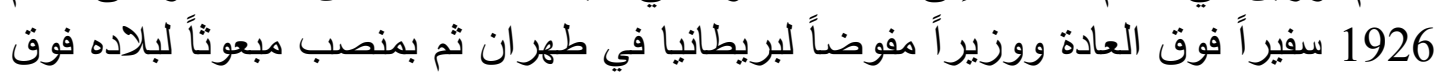

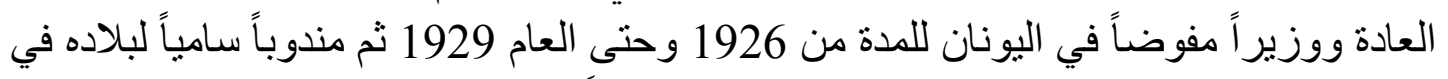
مصر بين عامي 1929- 1933بعدها عمل لورين سفير اً لبلاده في تركيا للمدة من العام العنام 1933

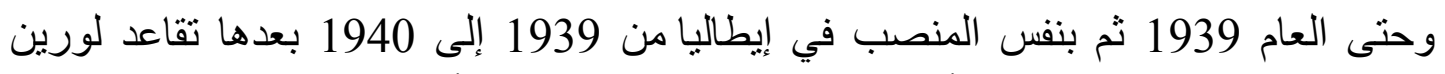
و انصرف إلى تربية الخيول الأصيلة لسباق الخيل ، وفي 23 أيار العام 1961 توفي اليطي السير 1939 توفي

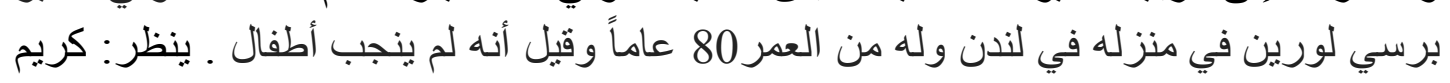

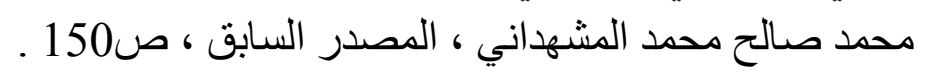

(1) نتيجة للضغط البريطاني على الحكومة العر اقية ، أصدر مجلس الوزر اء العر اقي قراراً في 28

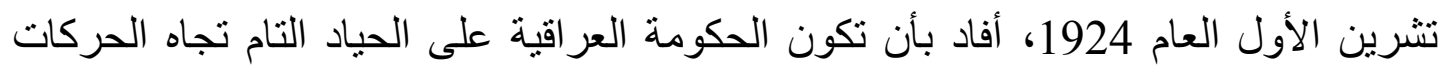

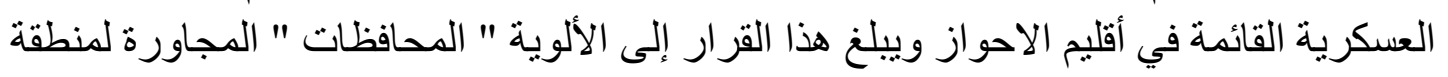

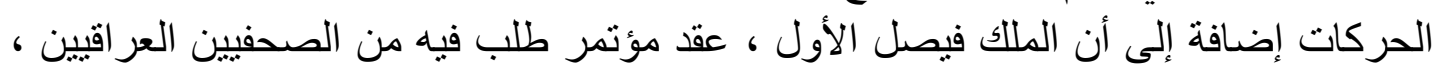




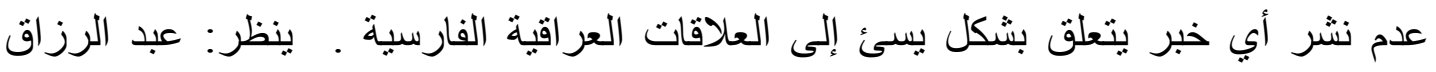

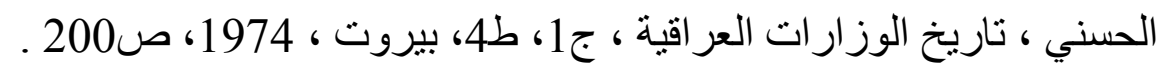

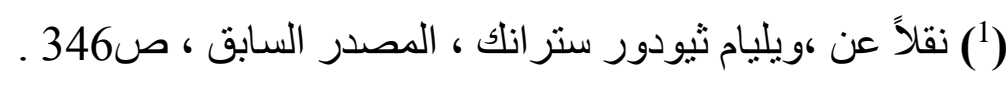

(1) (1) (1) ينظر: المصدر نفسه ، ص346.

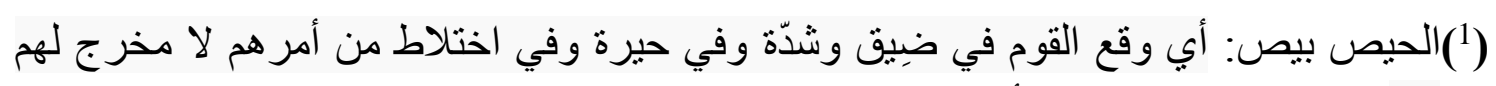

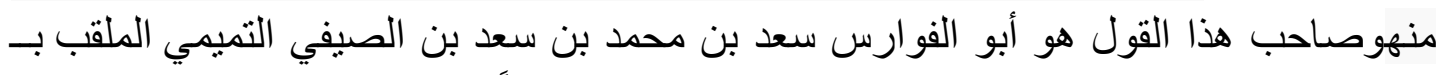

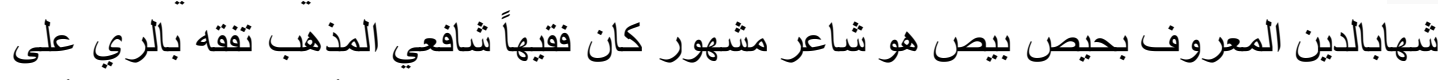

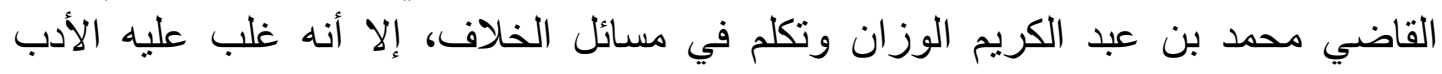

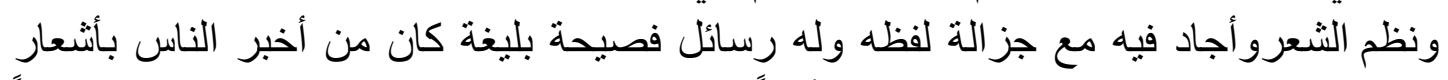

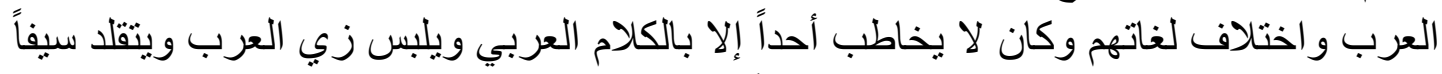

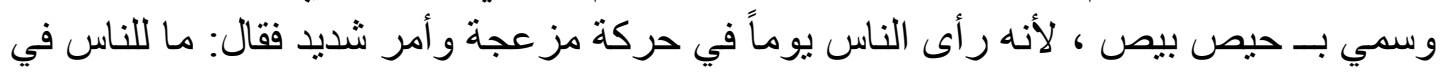
حيص بيص فبقي عليه هذا اللقب.

(1) ينظر : الثيخ عبد القادر باش اعيان العباسي ، المخطوطة ....، الورقة 75 .

(1) ينظر : الثيخ عبد القادر باش اعيان العباسي ، المخطوطة ....، الورقة 76 .

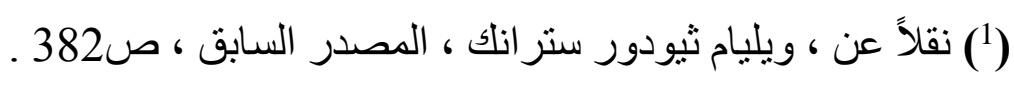

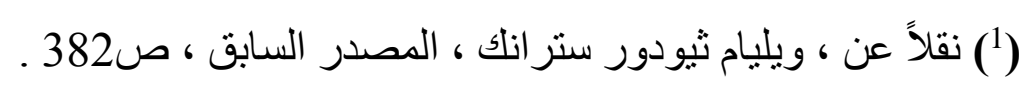

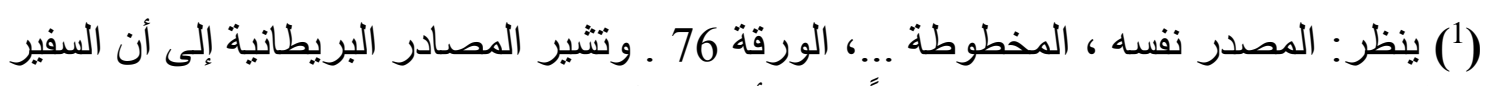

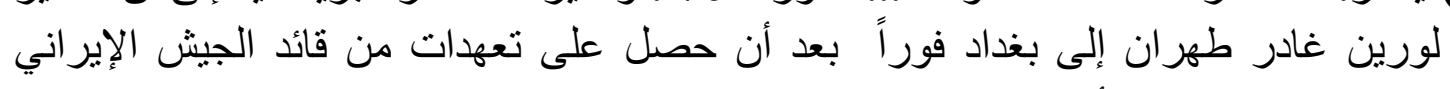

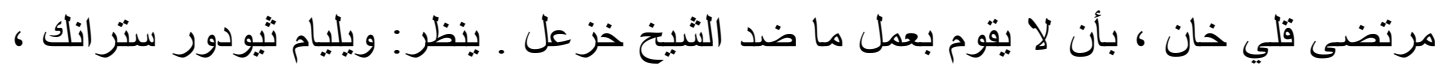

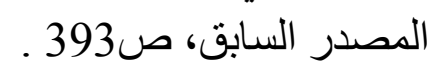

(1) ينظر: المصدر نفسه ، المخطوطة ....، الورقة 76 .

(1) ينظر: المصدر نفسه ، المخطوطة ...، الورقة 76 .

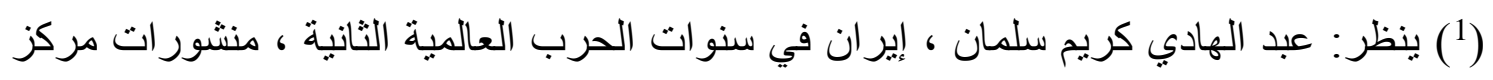

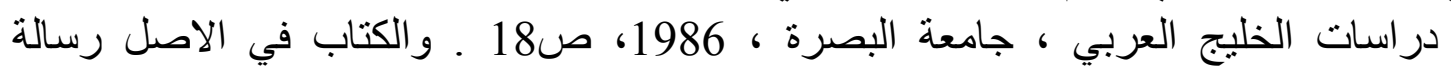
ماجسنير مران

(1) ينظر : الثيخ عبد القادر باش اعيان العباسي ، المخطوطة ... ، الورقة 78 ـ. 


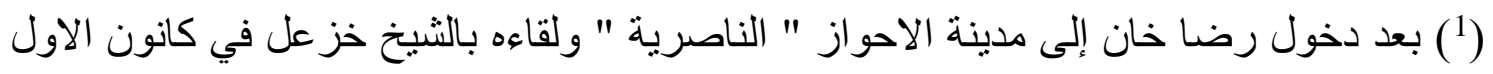

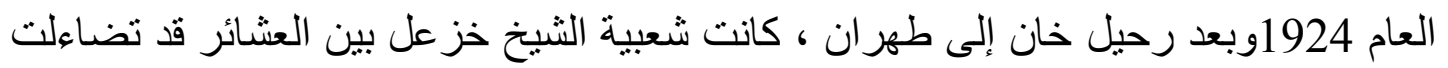

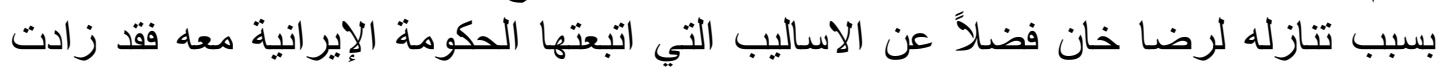

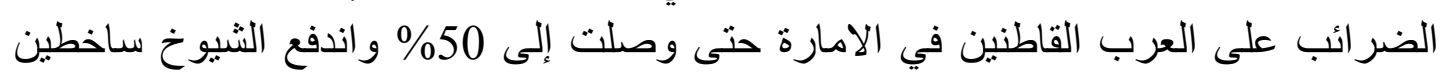

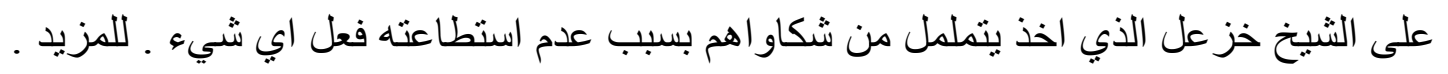

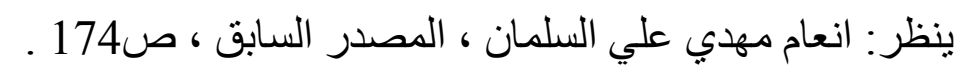

(1) الحاج محمد علي البهبهاني: شيخ التجار في المحرة ويتمتع بشخصية قوية وكان وزير اً للشيخ

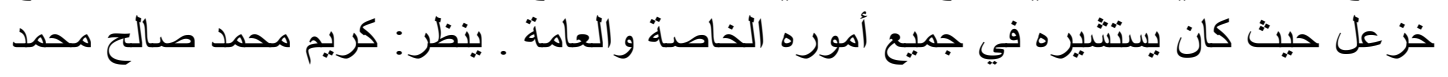

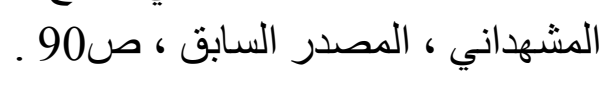

(1) بنظر : الثيخ عبد القادر باش اعبان العباسي ، المخطوطة ... ، الورقة 78 .

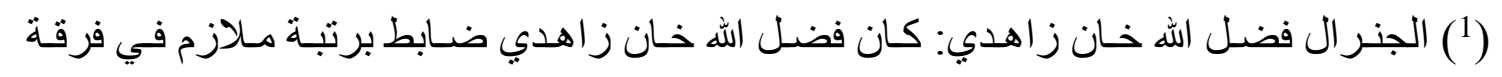

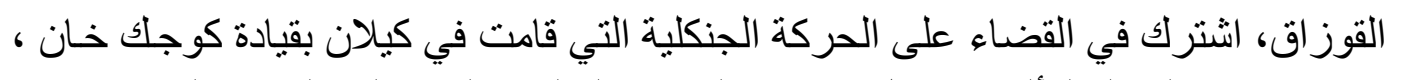

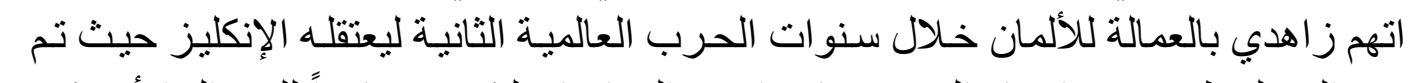

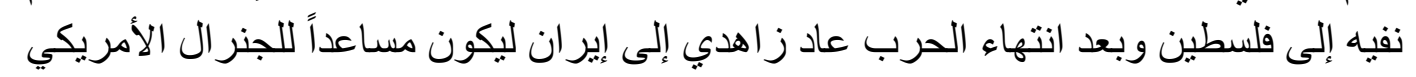

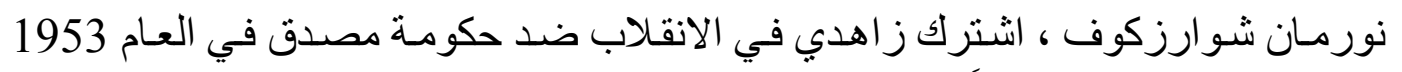

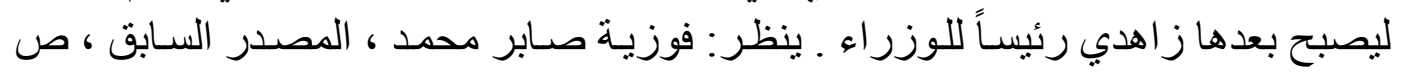

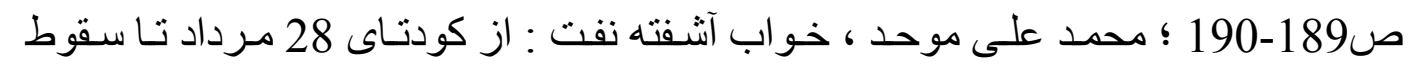

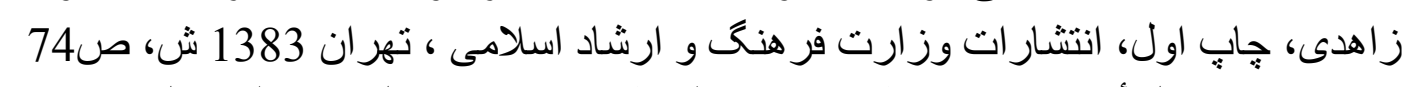

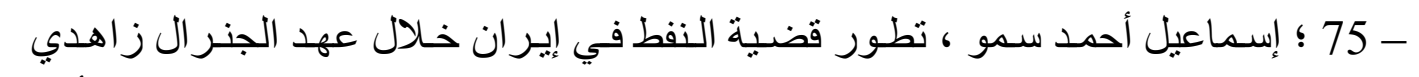

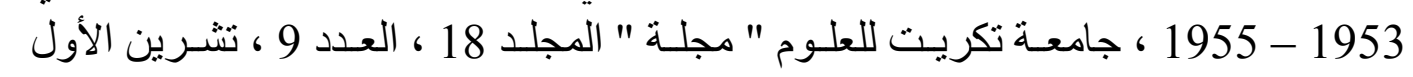

$$
\text { .2011 - } 2011
$$

(1) ينظر : الثيخ عبد القادر باث اعبان العباسي ، المخطوطة ... ، الورقة 78 . (1)

(1) ينظر : الثيخ عبد القادر باش اعيان العباسي ، المخطوطة ... ، الورقة 79 .

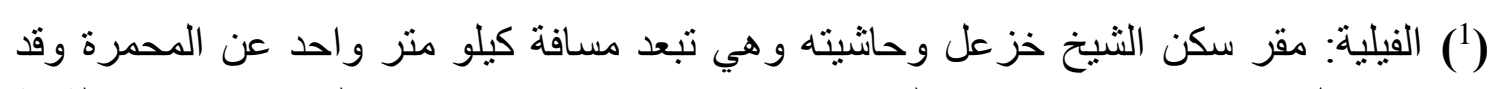

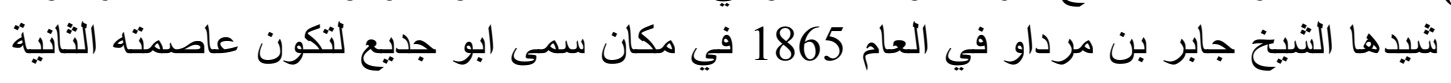


بعد المحمرة عاصمته الأولى وذلك في المدة الثانية من حكمه و التي امتدت بين عامي 1861-

(1) ينظر : الثيخ عبد القادر باش اعيان العباسي ، المخطوطة ... ، الورقة 79 . (1) ينظر: علي نعمة الحلو ، المصدر السابق ، ص127 .

(1) ويبدو أن قصة إلقاء القبض على الشيخ خزعل تركت في نفس الجنرال زاهدي ، أثراً عميقاً

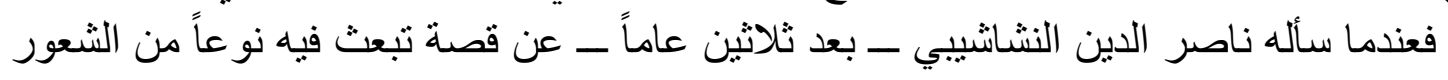

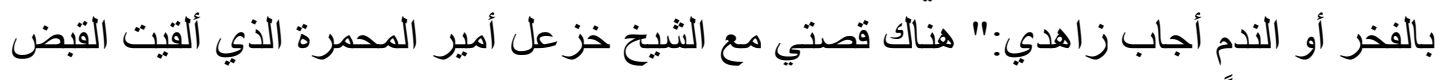

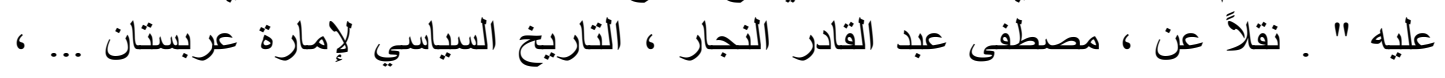
ص248

(1) ينظر : المصدر نفسه ، ص128 .

(1) ينظر: الثيخ عبد القادر باش اعيان العباسي ، المخطوطة ... ، الورقة 80 . (1) ينظر : الثيخ عبد القادر باش اعيان العباسي ، المخطوطة ... ، الورقة 80 . (1) للمزيد ـ ينظر: الثيخ عبد القادر باش اعيان العباسي ، المخطوطة ... ، الورقة 80 و 81 . (1) للمزيد ـ ينظر : الثيخ عبد القادر باش اعيان العباسي ، المخطوطة ... ، الورقة 80 و 81 . (1) لم تسمح الحكومة الإير انية بنقل جثمان الثيخ خز عل بعد وفاته ، إلا بعد مرور ستة عثر عاماً

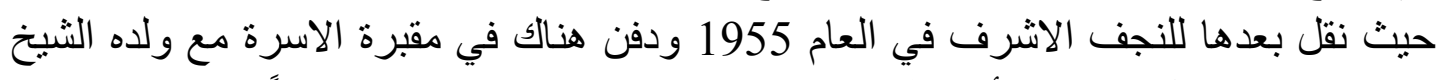
عبد الحمبد باحتفال كبير وقد أرخ الثيخ علي البازي الاديب النجفي وفاته قائلاً: رمت به خز علا

$$
\begin{aligned}
& \text { وقومه بالغدر لمـــــا انجلا } \\
& \text { أمير خوزستان عن دسته } \\
& \text { فأرخو ا " رمت به خز علا " } \\
& \text { صوبت السهم لــــه فارس } \\
& \text { و هذا البيت يشير إلى سنة } 1355 \text { هـ تاريخ وفاته } \\
& \text { ينظر : علي نعمة الحلو ، المصدر السابق ، ص247 . }
\end{aligned}
$$

(1) توفي الثيخ عبد الحميد بعد و الده بثلاث سنوات أي في العام 1939 في معتقله في طهران أيضاً 


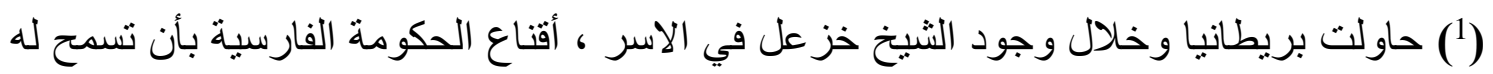

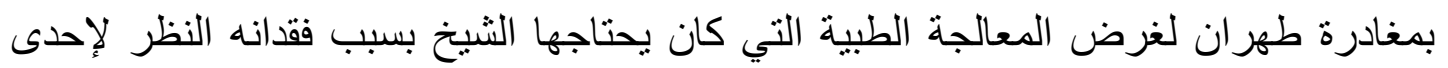

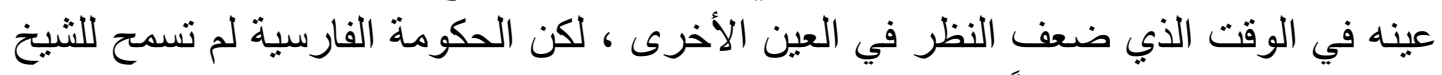

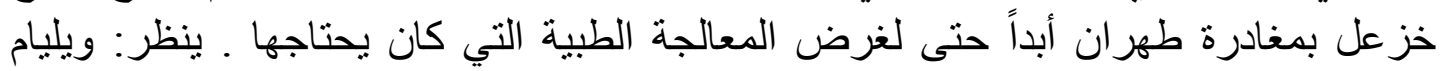

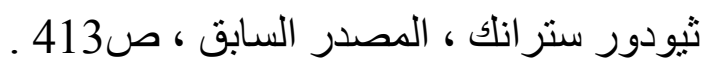

(1) قيل انه وبعد أن استنزف رضا خان جميع اموال الثيخ خز عل أمر بعض الأعراب ومنهم أحد

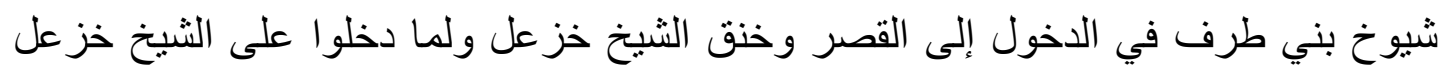

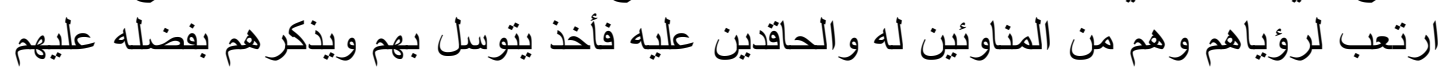

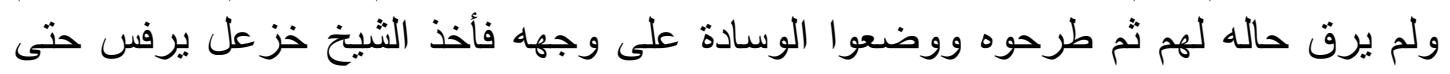

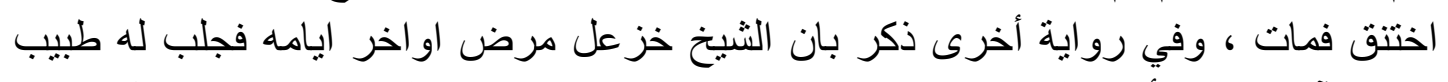

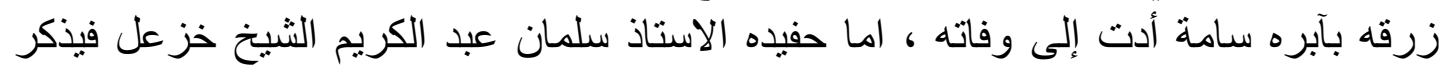

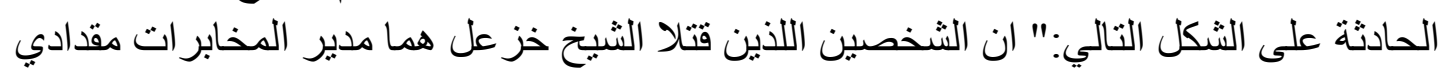

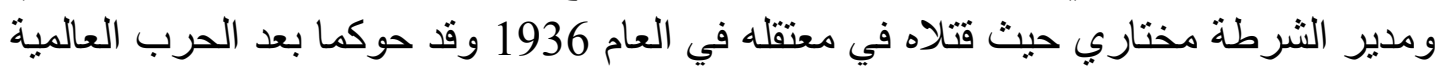

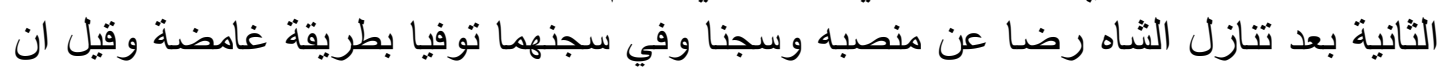

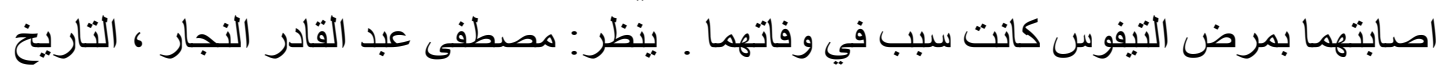

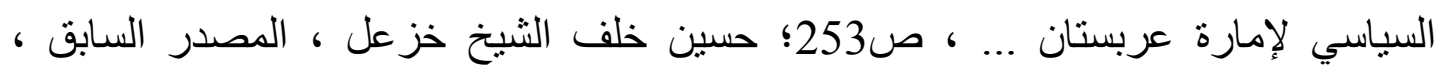

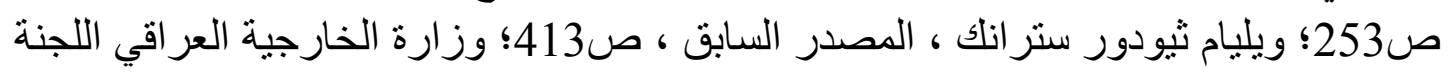

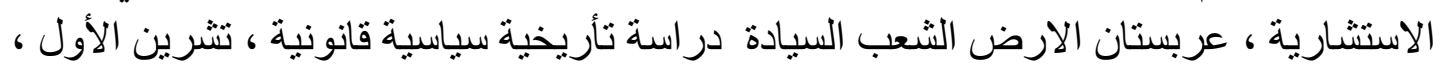

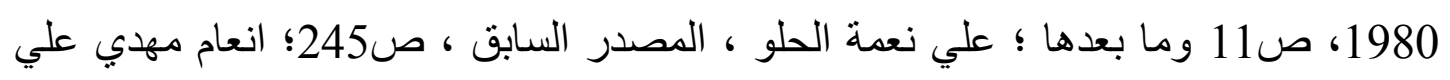

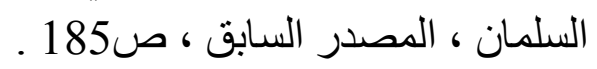

(1) نقاًً عن ، مصطفى عبد القادر النجار ، التاريخ السياسي لإمارة عربستان العربية ... ،

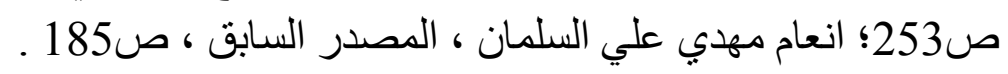

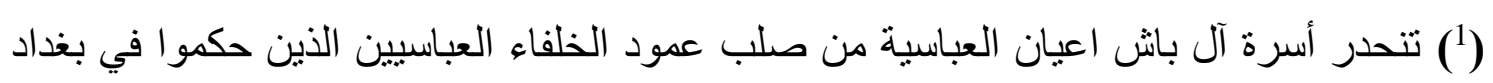

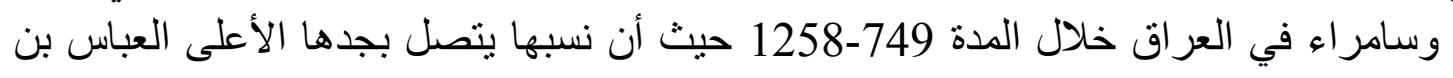

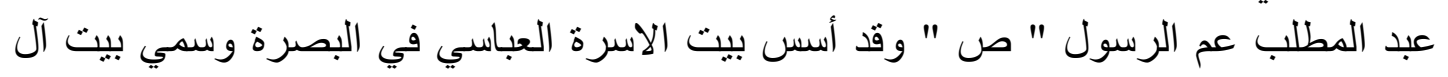

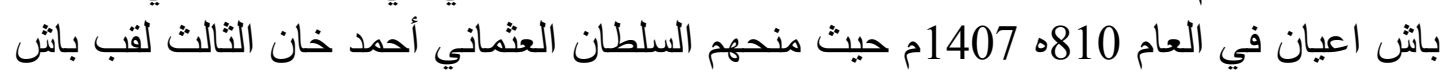

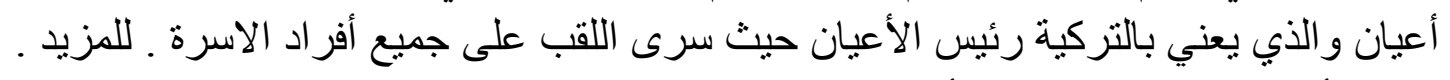

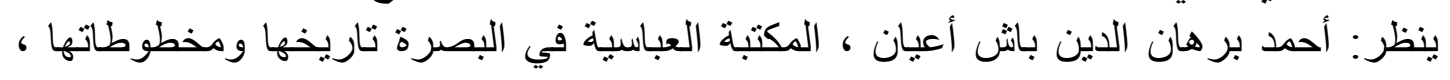

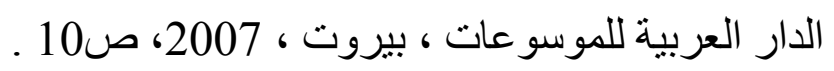


(1) عرف عن أسرة آل باش اعيان في البصرة ، الوجاهة الكبيرة والزعامة التي تحلتها الاسرة بين

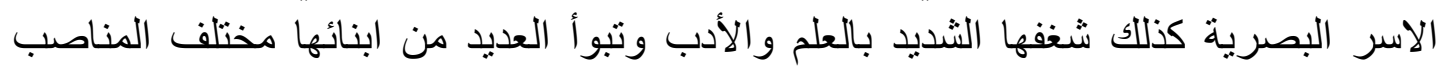
الادارية و الحكومية ففي العام 1921 عين الثيخ صالح متصرفاً للو اء العمارة وفي العام 1923

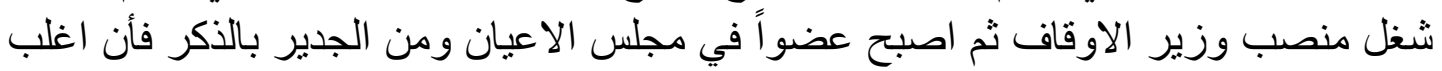

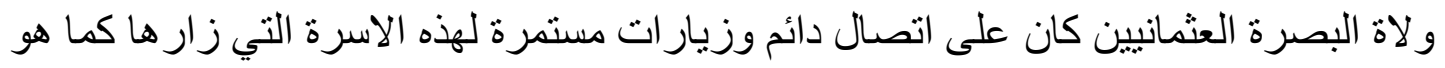

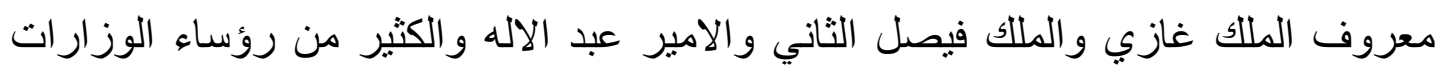

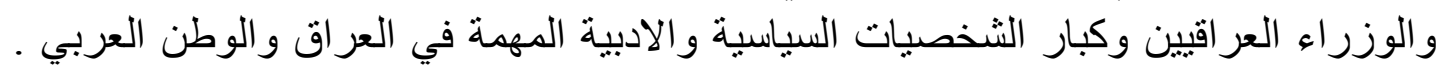

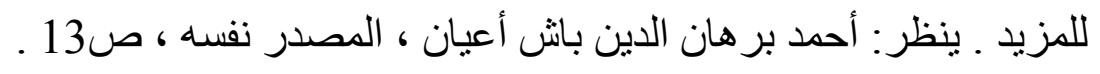

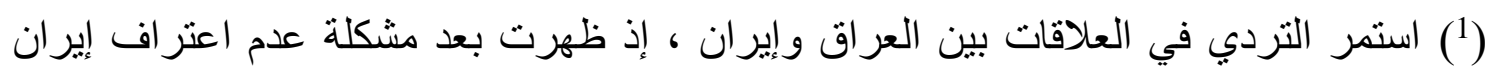

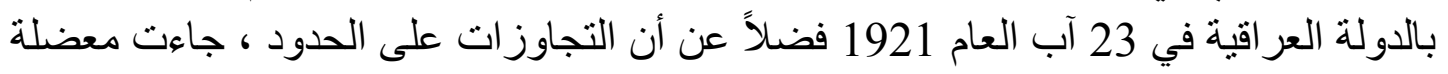

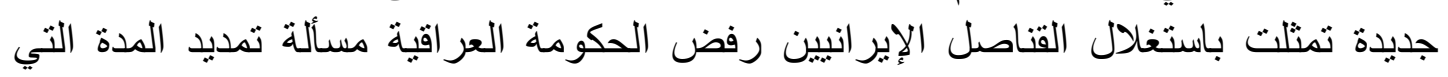

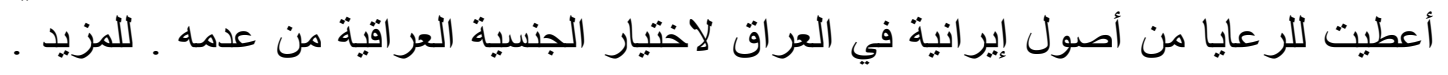

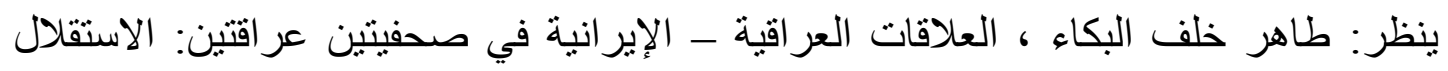
و العالم العربي 1920 - 1932، " المؤرخ العربي " ، " مجلة " ، العدد 32 ، بغداد ، 1978 ، 1920 ص ص 45.

(1) كثير اً ما كان الثيخ خزعل يتفاخر بنفسه وجيشه وقو اته هذه ، فكان يستعرض هذا الجيش كلما

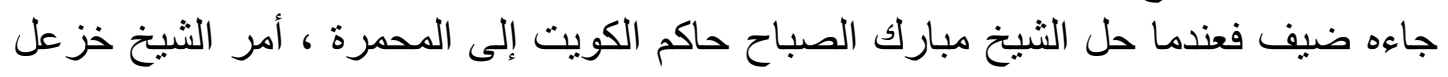

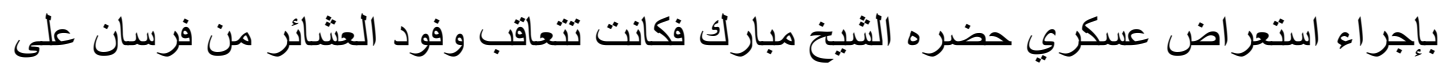

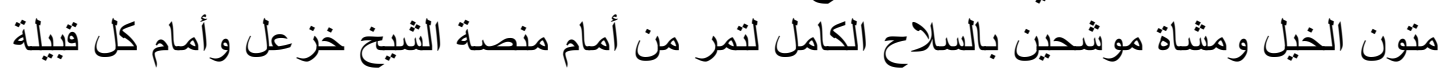

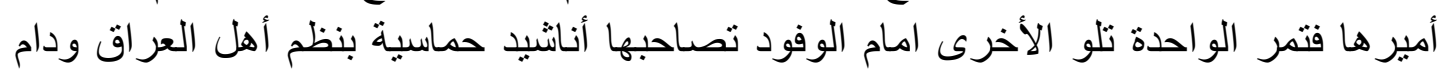
الاستعر اض قر ابة ساعتين وقد تخلل هذا الاستعر اض ، فل مناور الات عسكرية بين القبائل العربية

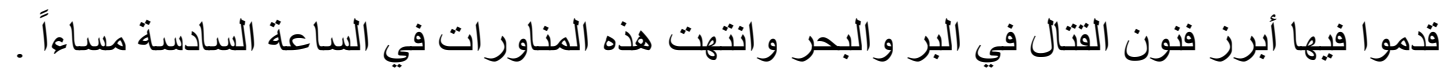

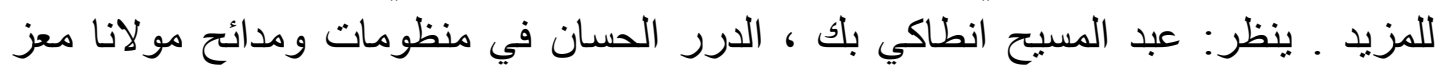

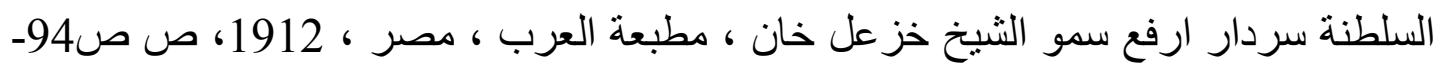

(1) عرف عن الثيخ خزعل اعتداده بنفسه وطموحه السياسي الكبير فالرجل تسلم الامارة بمؤامرة

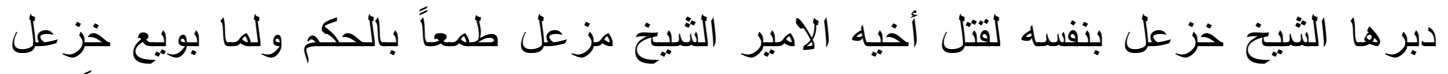

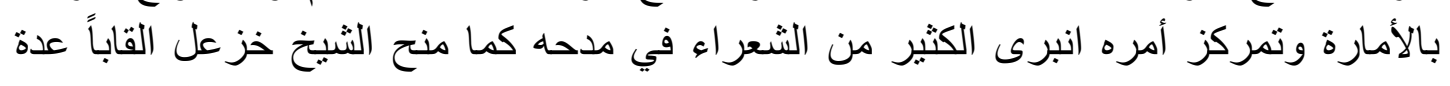

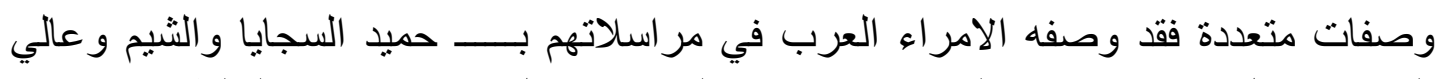

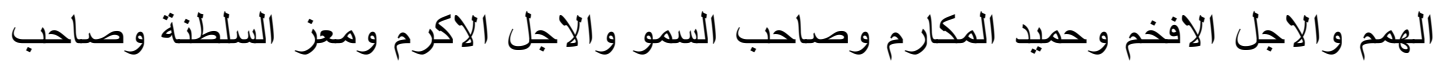


الدولة و المفخم والملاذ الاعظم ومو لاي و الاجل الاكرم الافخم الاشيم حميد الثيم وجناب الاصل

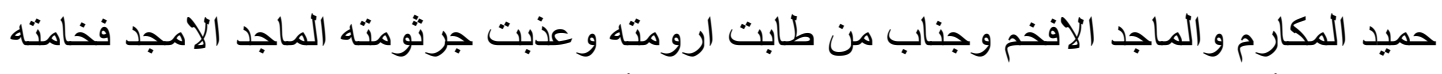

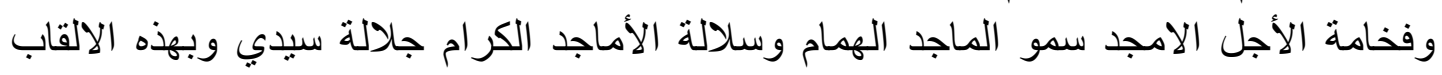

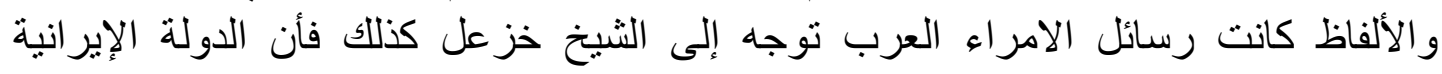

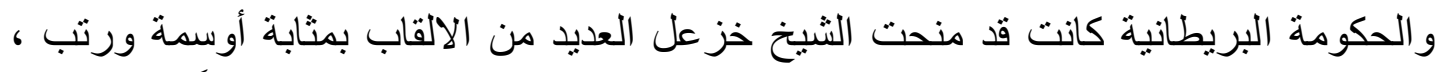

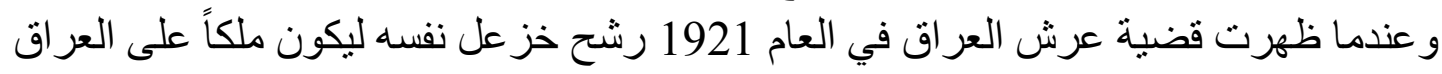

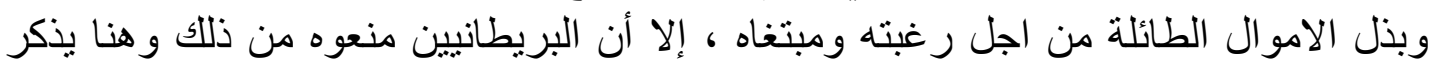

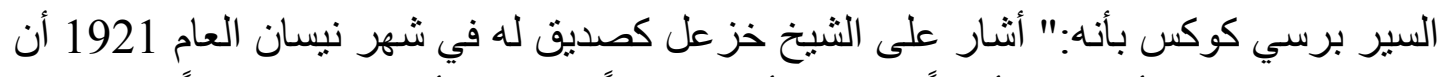

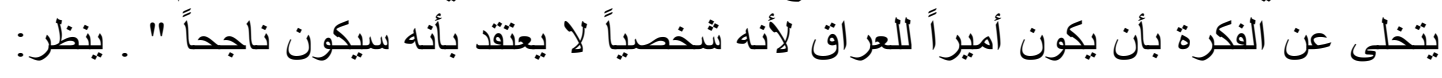

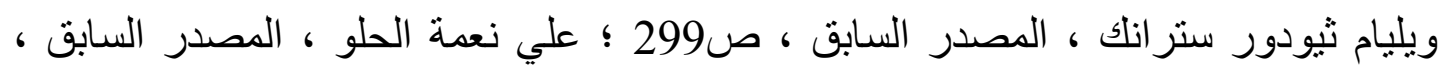

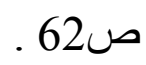

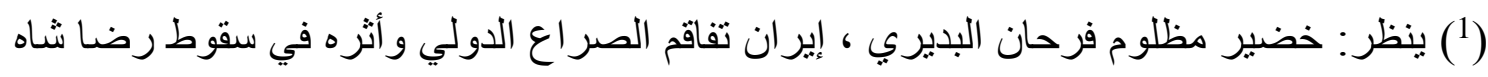

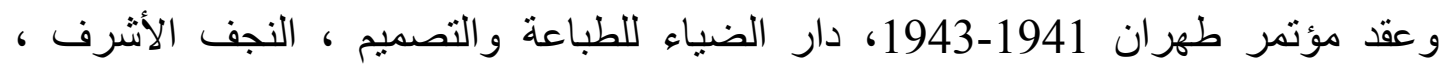

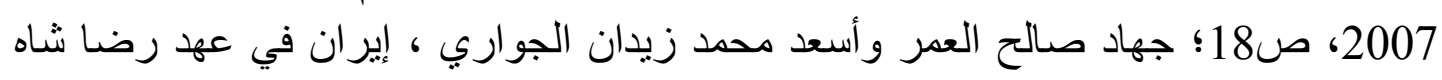

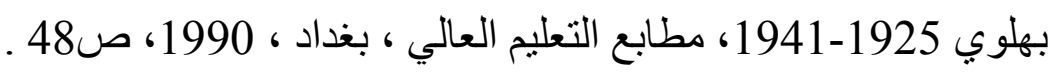

(1) يعد اللورد جورج كيرزن من أثهر الثخصيات البريطانية ولد في 11 كانون الثاني العام

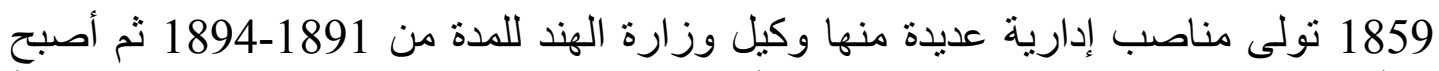

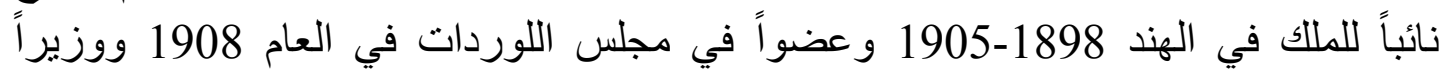

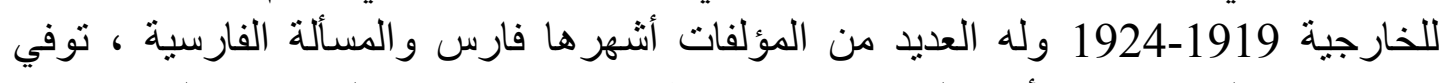

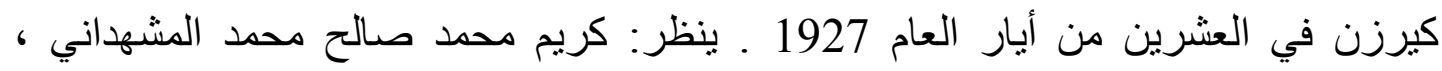

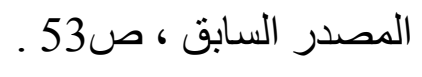

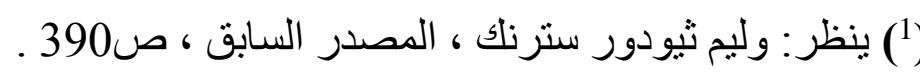
(1) ينظر : مصطفى عبد القادر النجار ، التاريخ السياسي لإمارة عربستان العربية ... ، ص248 . (1) ينظر: جان جالك بيربي ، الخليج العربي ، ترجمة نجدة هاجر وسعيد الغز ، بيروت ، 1959، ص98. (1) 


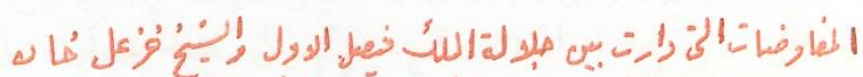

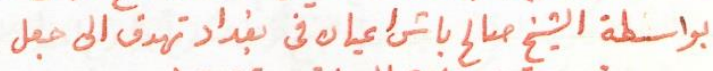

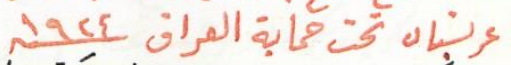

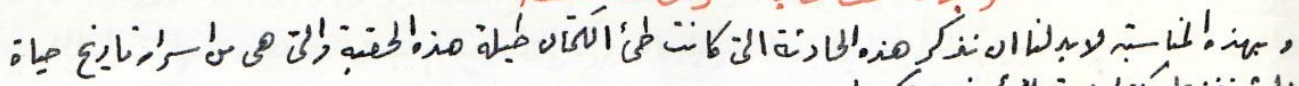

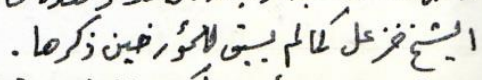

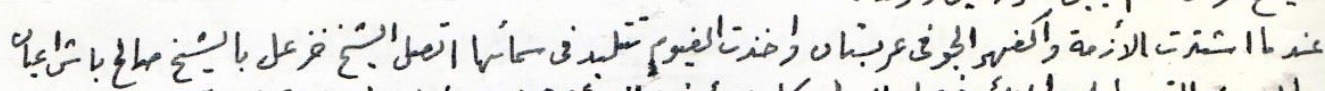

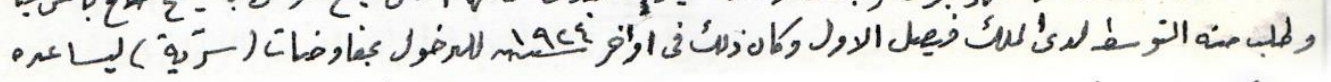

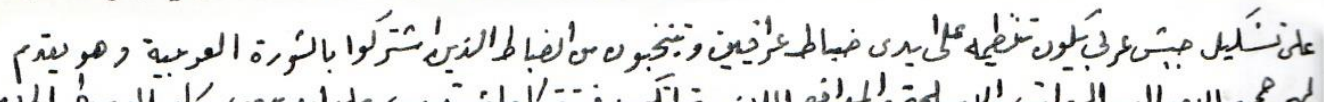

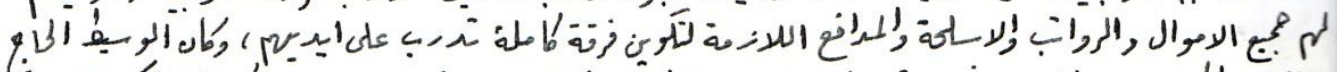

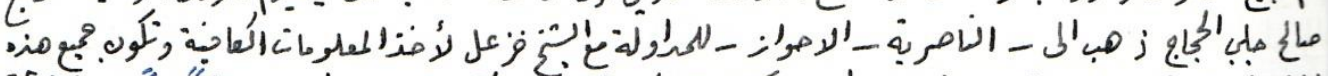

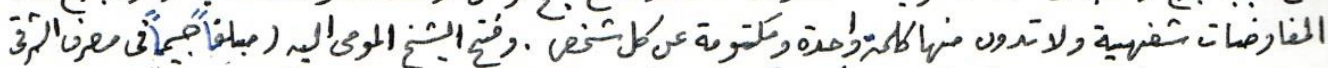

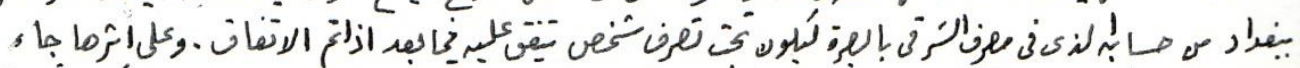
3-

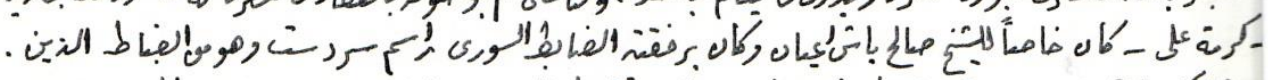

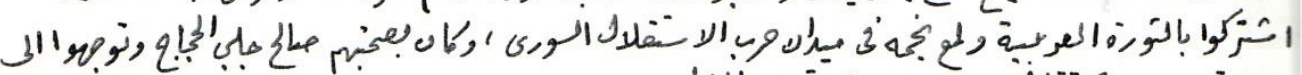

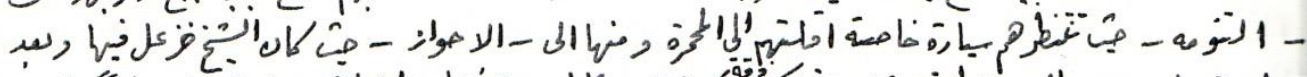

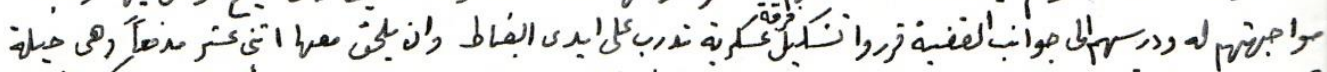

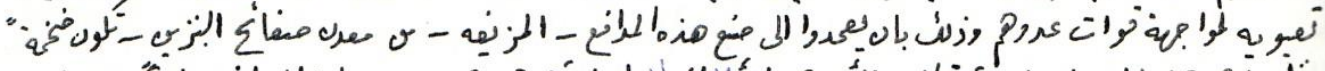

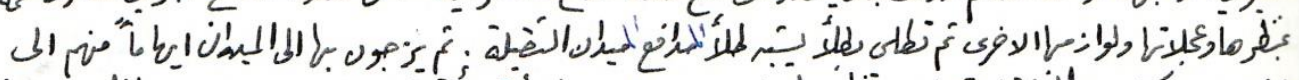

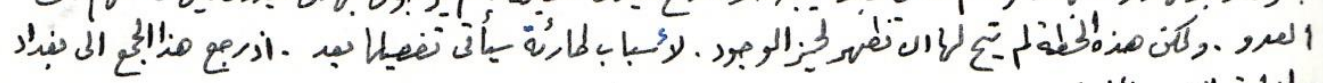

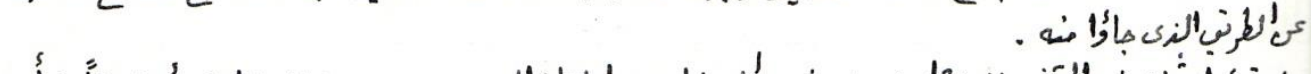

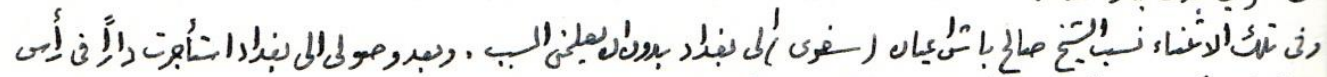

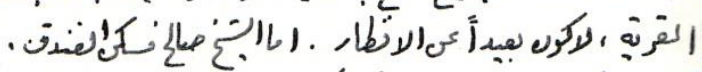

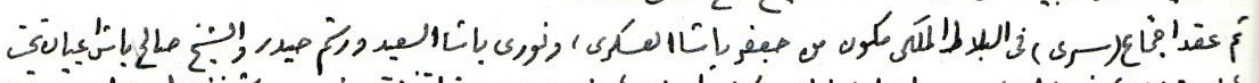

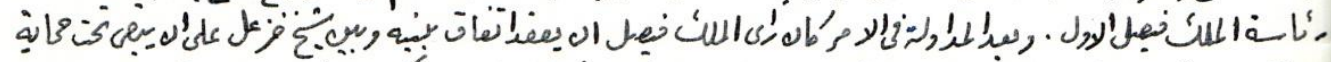

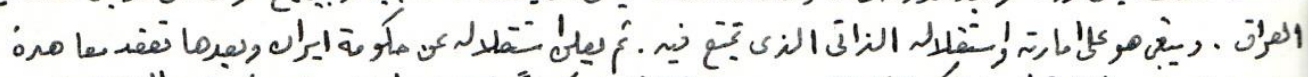

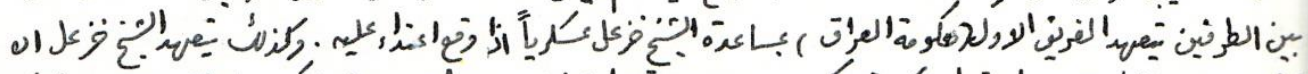

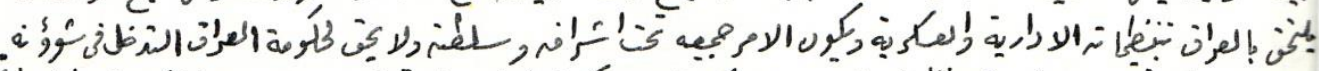

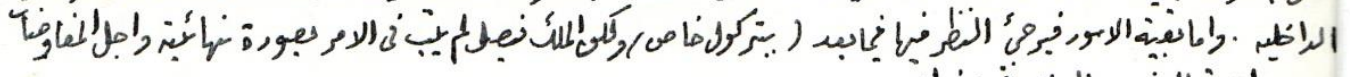

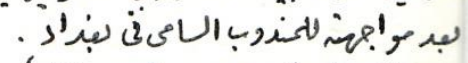

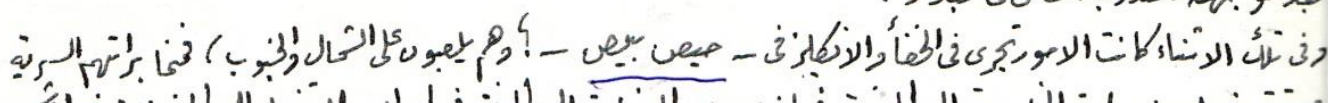

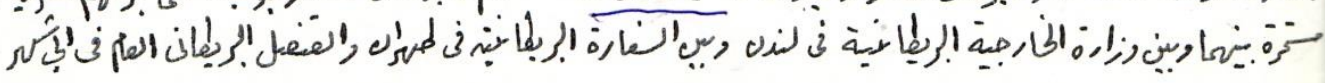


الورقة 75 مصورة من المخطوطة الاصل للثيخ عبد القادر باش اعيان العباسي .

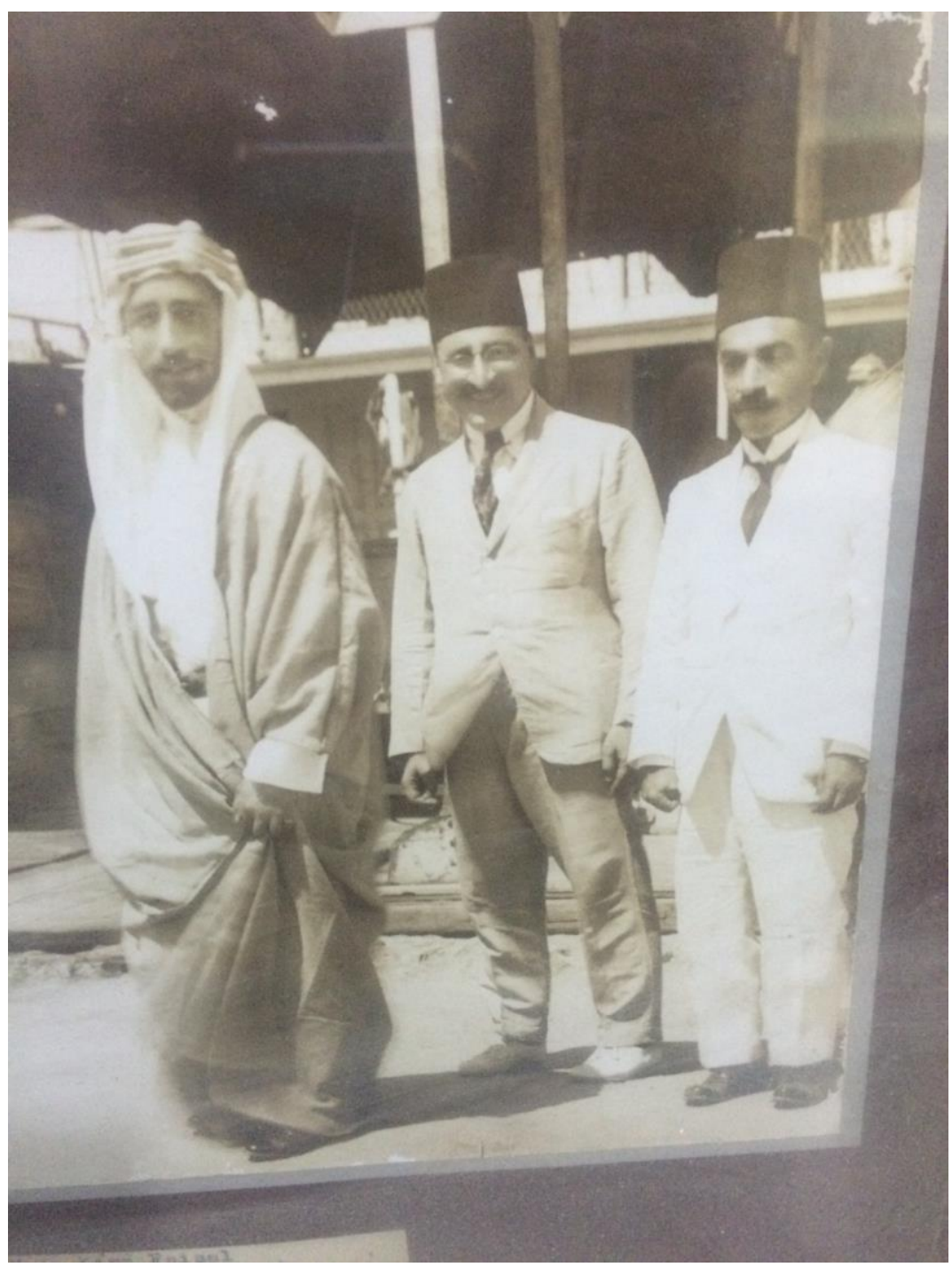

الملك فيصل الأول في البلاط الملكي ويرى خلفه من يمين الصورة الثيخ صالح باش اعيان العباسي ورستم حيدر والصورة في 25 تشرين الأول العام 1924 .

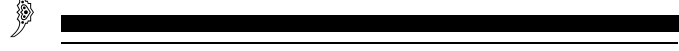




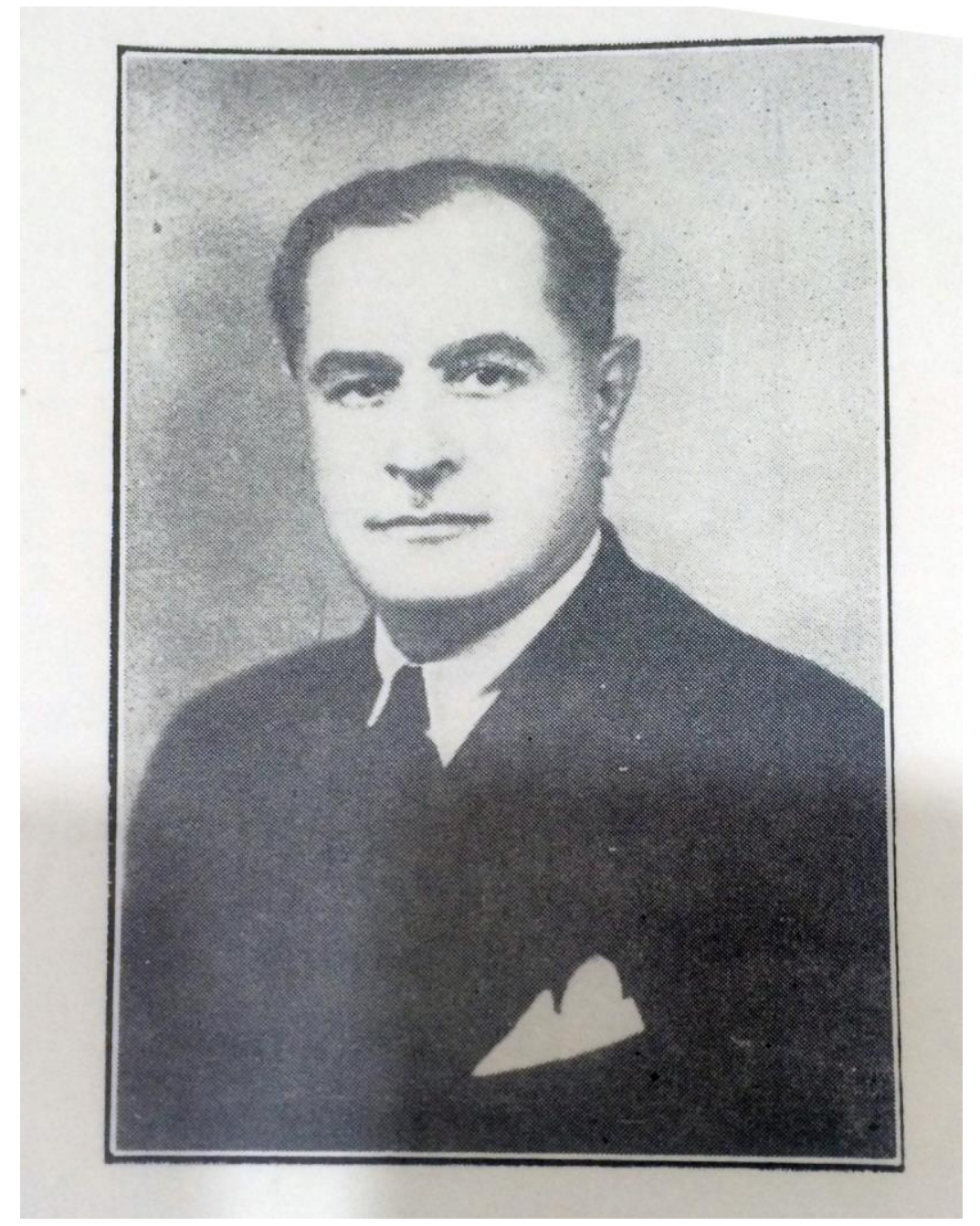

كاتب المخطوطة الثيخ عبد القادر باش اعيان العباسي 1893- 1971 ـ

$$
\text { الولاً: المخطور والمراتع }
$$

مخطوطة الثيخ عبد القادر باش اعيان العباسي ، الاحواز و وعربستان في تاريخنا ، الجزء الأول ، المجلد التاسع عشر ، مخطوطة بـ 116صفحة محفوظة لدى الاسرة العباسية في البصرة. 


\section{الوثائق الحكومية المنشورة}

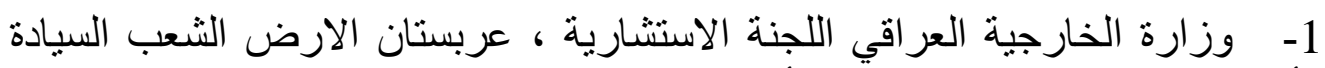

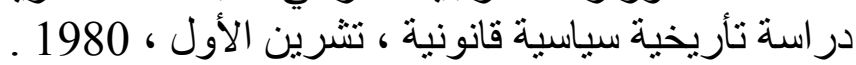

ثانياً: الرسائل الجامعية

1- إنعام مهدي علي السلمان ، أثر هنري دوبس فئل في السياسة العر اقية 1923-1929، أطروحة

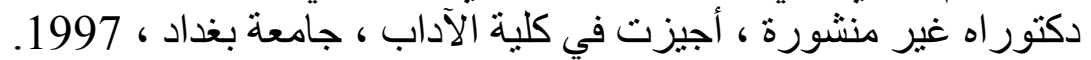

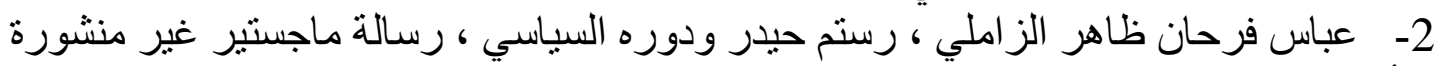

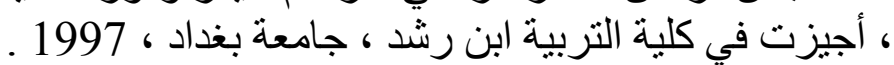

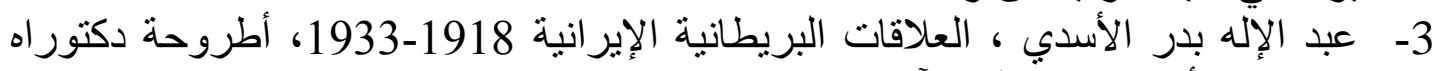

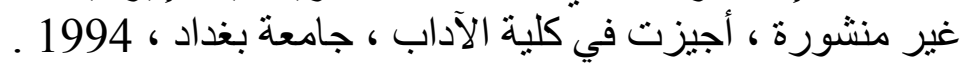

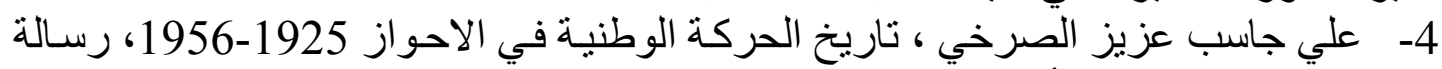

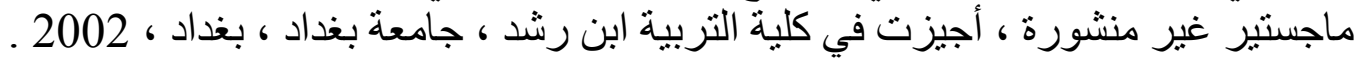

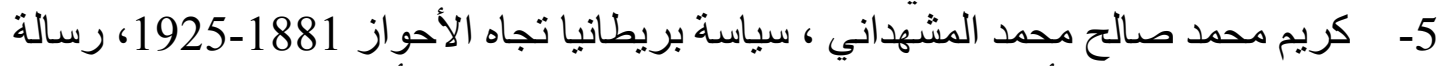

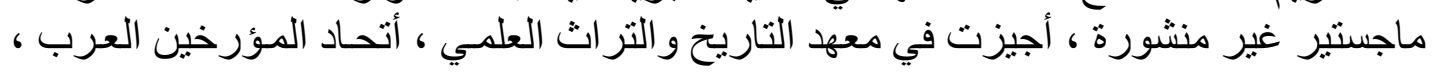

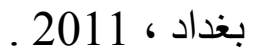

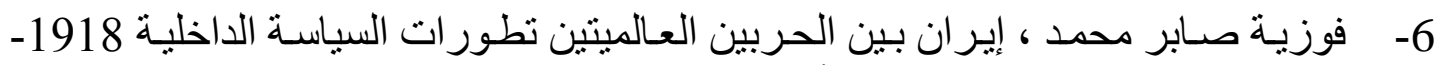

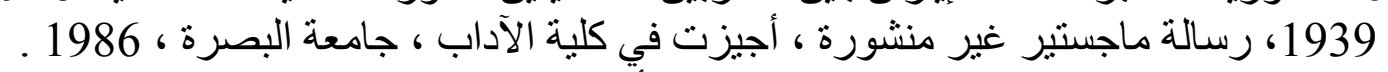

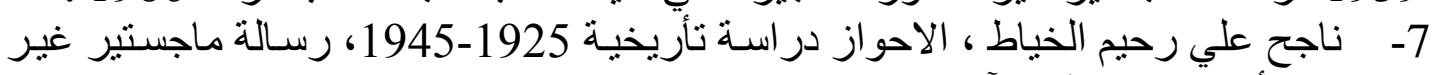

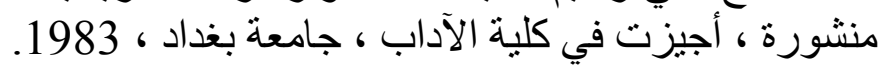

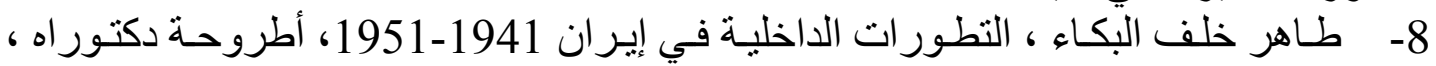

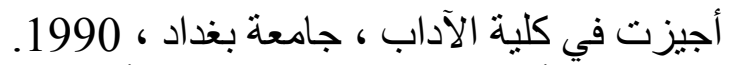

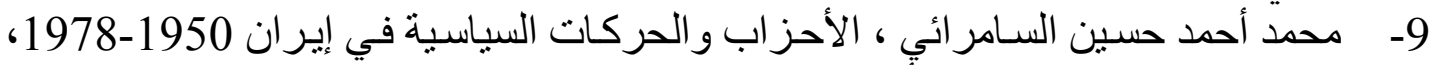

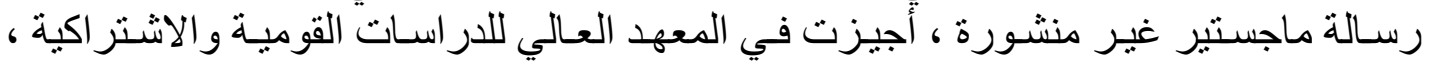

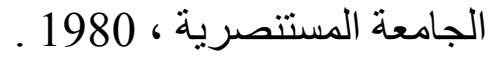
ثالثاً: المذكرات الثخدصية

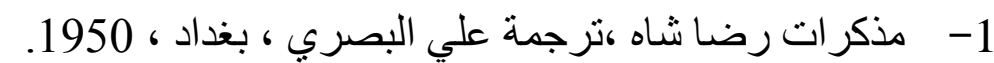

2- نجدة فتحي صفوة ، مذكرات جعفر العسكري ، دار اللام ، لندن ، 1988 ، 1980.

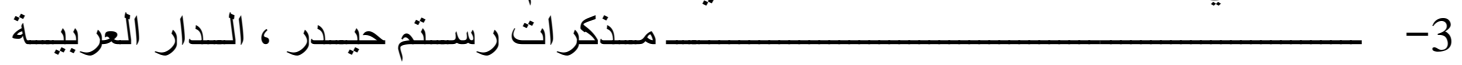

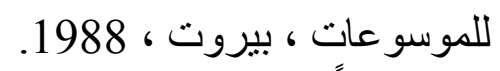
رابعاً: الكتب ـ الكتب العربية الكتبة والمعربة البية 1- إبر اهيم خليل أحمد وخليل علي مر اد ، إير إير ان وتركيا در اسة في التاريخ الحديث و المعاصر

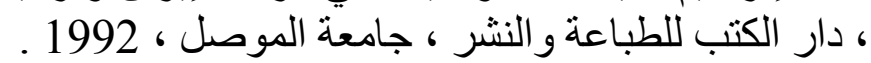
2- إبر اهيم خلف العبيدي ، الاحواز أرض عربية سليبة ،ط2، بغداد ، 1982 ـ 
3- أحمد بر هان الدين باش أعبان ، المكتبة العباسية في البصرة تاريخهاو وخطوطاتها ، الدار

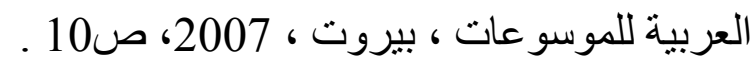

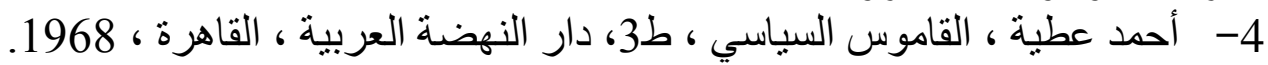

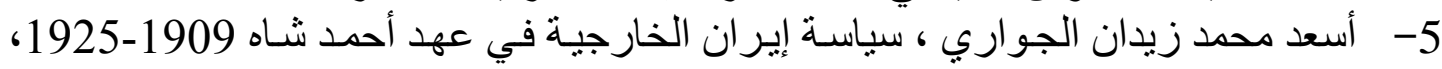

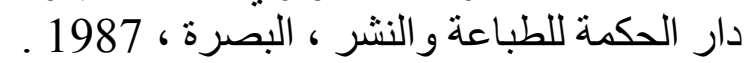

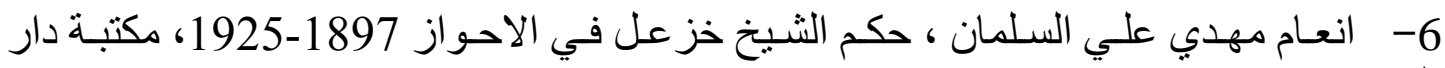
الكندي ، بغداد ، 1985. 7- ج ج • ج ، لوريمر ، دليل الخليج القسم الجغر افي ، ترجمة مكتب صـاحب السمو أمير دولـة

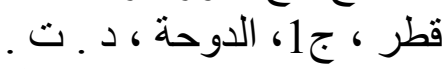

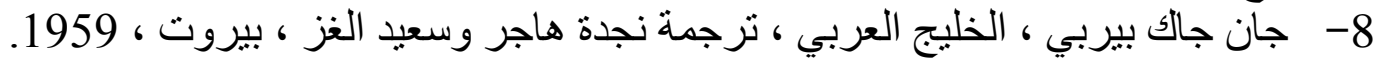

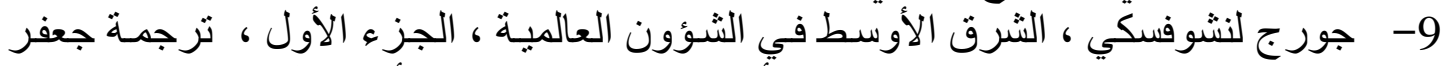

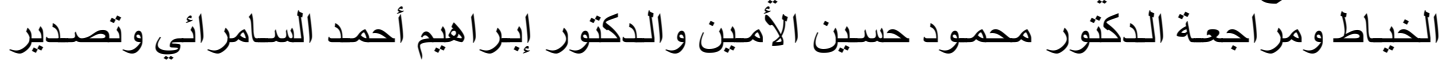

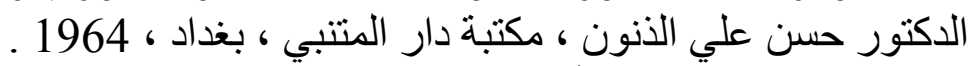

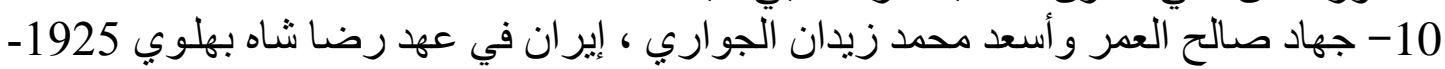

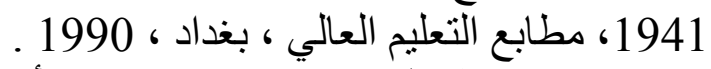

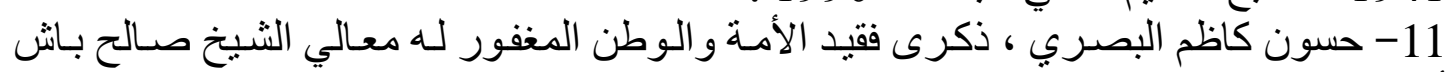

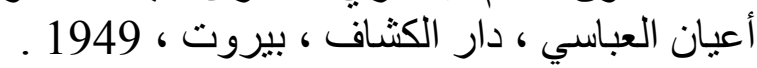

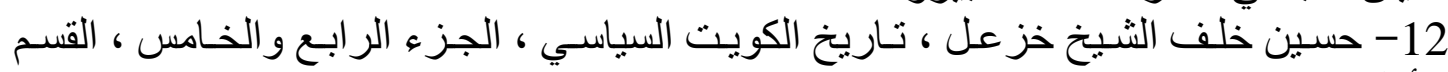

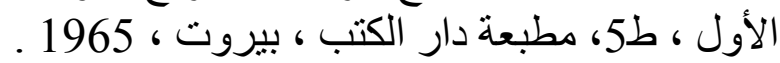

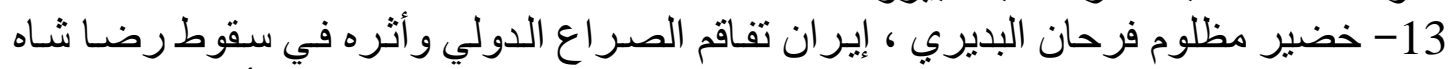

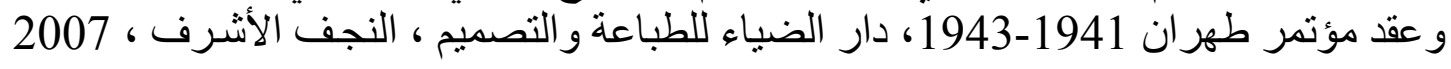

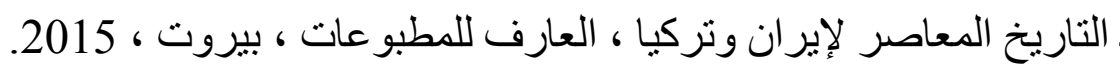

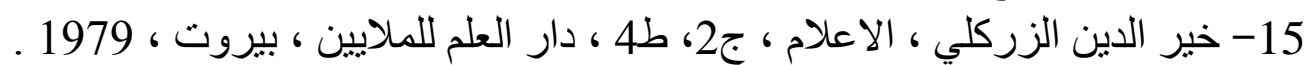

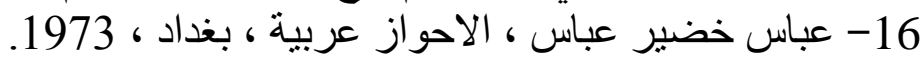

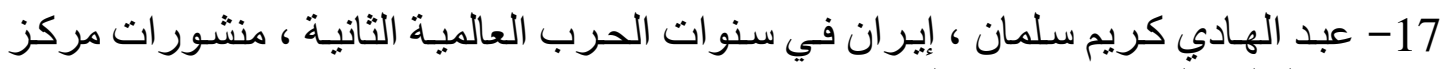

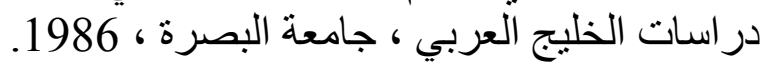

18- عبد الرزاق احمد النصبري ، نوري التيعة السعيد ودوره في السياسة العر اقية حتى عام 1945 ، بغداد ، 1988 198

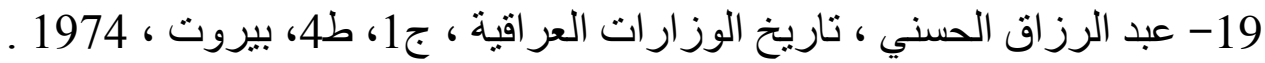

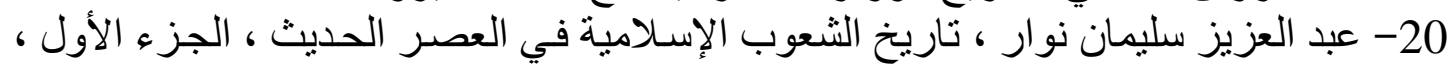

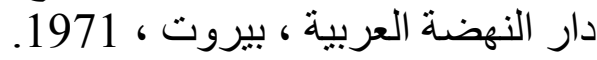
21- عبد المسيح انطاكي بك ، الدئه ، الدرر الحسان في منظومات ومدائح مو لانا معز السلطنة سردار ارفع سمو الثيخ خز عل خان ، مطبعة العرب ، مصر ، الثر ، 1912. 
22- علي نعمة الحلو ، الاحواز " عربستان " امارة كعب العربية في المحمرة ، ج3، بغداد ، . 1969 23- علاء جاسم محمد ، جعفر العسكري ودوره السياسي والعسكري في تاريخ العراق حتى

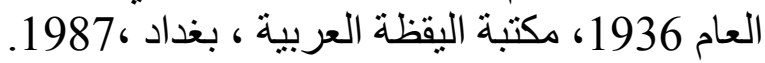

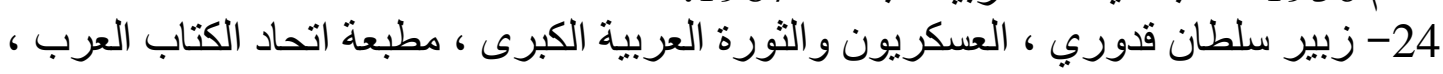

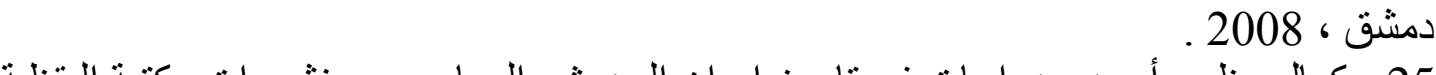
25- كمال مظهر أحمد ، در اسات في تاريخ إيران الحديث و المعاصر ، منشور ات مكتبة اليقظة

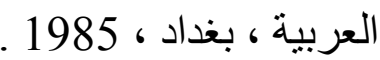
26- كارل بروكلمان ، تاريخ الشعوب الاسلامية ، نقله للعربية نبيه امين ومنير بعلبكي ، ط3، بيروت ، 1961 .

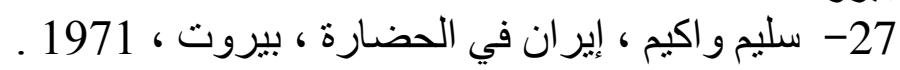

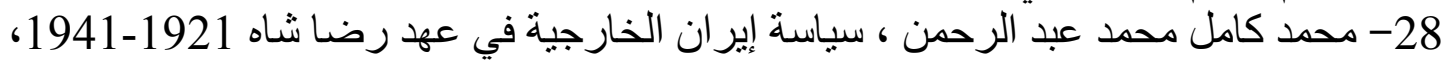

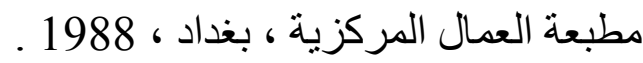
29- مصطفى عبد القادر النجار ، التاريخ السياسي لإمـارة عربستان العربية 1897-1925،

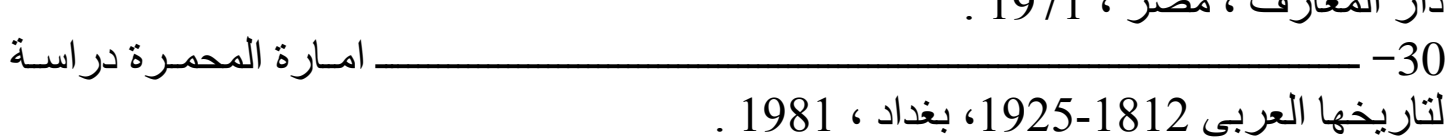

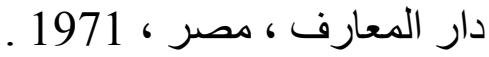

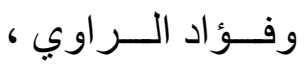
$-31$ التـأربخ عربستان الارض الثعب السيادة ، بغداد ، 1980 ـ القومي لأمسارة المحمرة العربيـة مـع تسـليط الضـوء على الاطمـاع الفارسية ، در اسـة تحليليـة ،

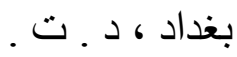
33- منذر عبد الكريم البكر ، الجذور التاريخية لعروبة الاحواز قبل الاسلام ، البصرة ، 1981 34- مير بصري ، أعلام السياسة في العراق الحديث ، الجزء الثاني ، دار الحكمة ، لندن ، 2004 35- ويليام ثيودور سترنك ، حكم الثيخ خز عل بن جابر واحتلال إمارة عربستان ، ترجمة عبد

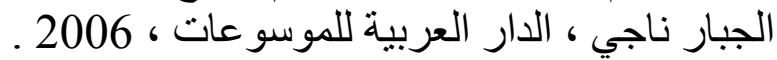
36- صـادق حسـن السـوداني ، صـفحات مـن تـاريخ عصـبة الأمـم ، دار الجـو اهري ، بغــداد ، 2013

37- صـالح أحمد العلي ، الاحواز في العهود الإسـلامية الأولى ، در اسـة في أحو الهـا الجغر افيـة

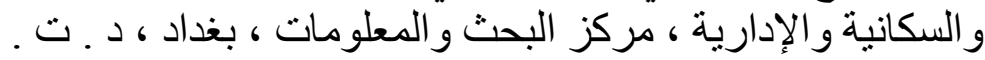
ـ الكتب الأجنبية

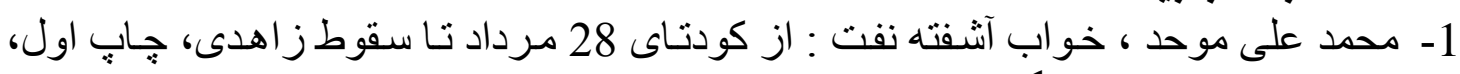
انتشار ات وزارت فر هنى و و ارشاد اسلامى ، تهر ان 
2- آل. لى. الولساتن، رضا شاه كبير وايران نو، ترجمـة، عبد العظيم صبوري، (تهران: جاب

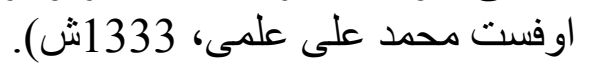

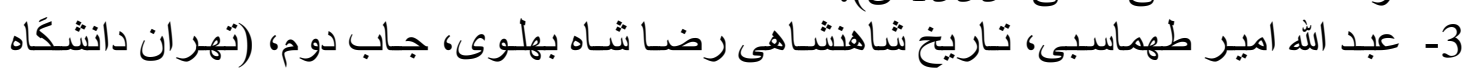

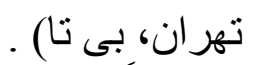

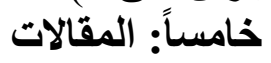

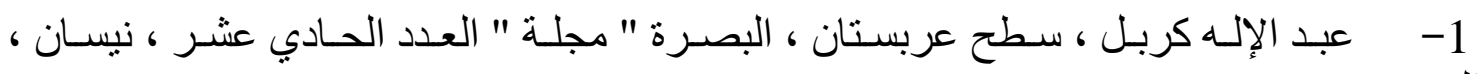

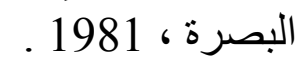

2- سليم طـه التكريتي ، الاحواز و المحمرة ، أفاق عربيـة " مجلة " ، العددان 3-4 ، ، السنة

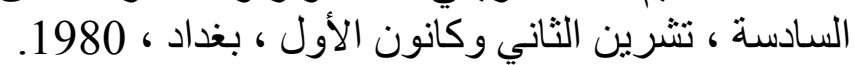

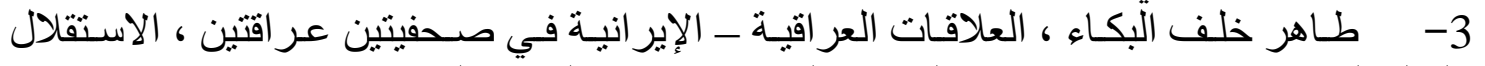

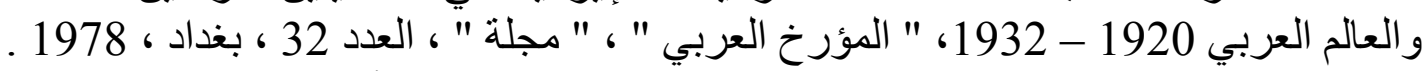

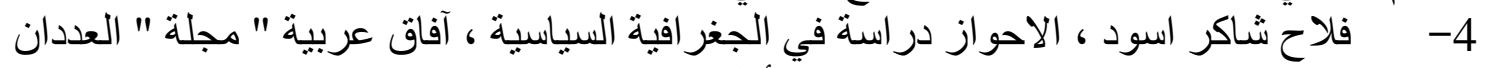

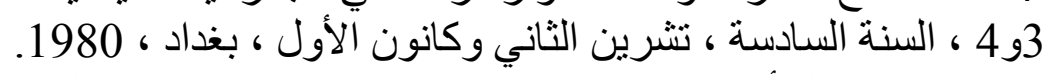

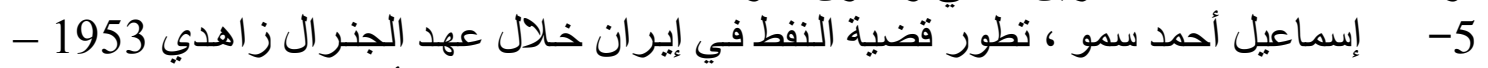
1955 ، جامعة تكريت للعلوم " مجلة " المجلد 18 ، العدد 9 ، تشرئ إيران فين الأول 2011 ، سادساً: الجرائد

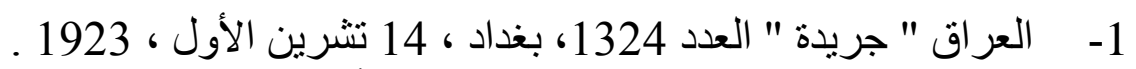

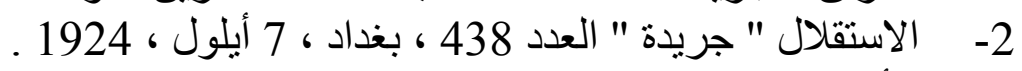

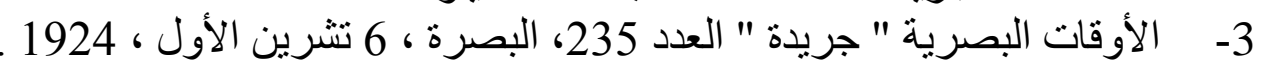

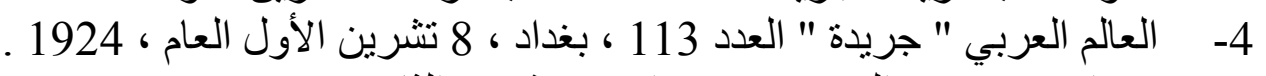

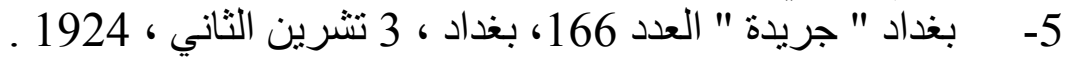

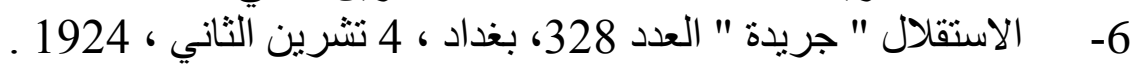

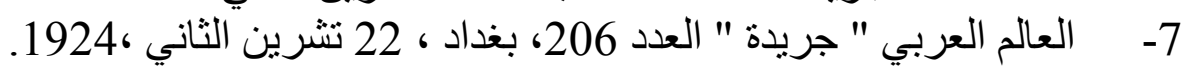

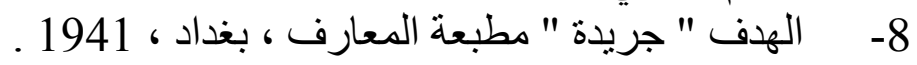




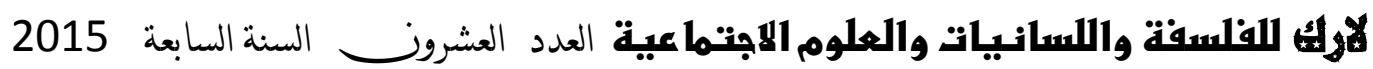
 


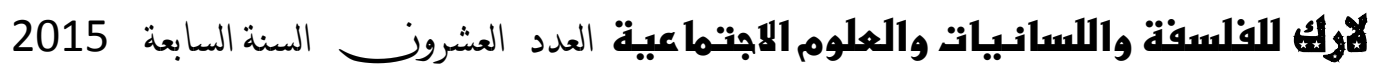
 


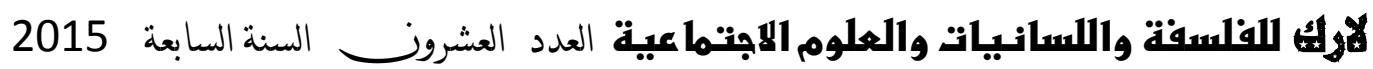
 


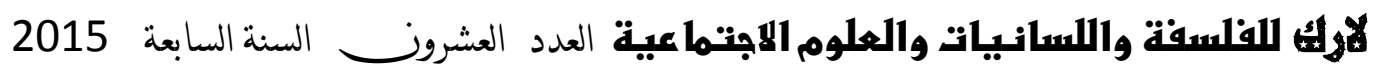
 


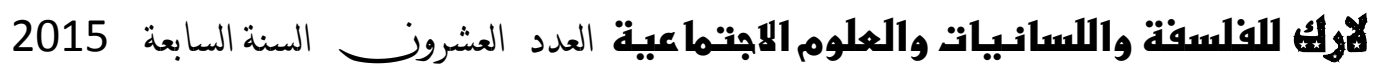
-

38) 


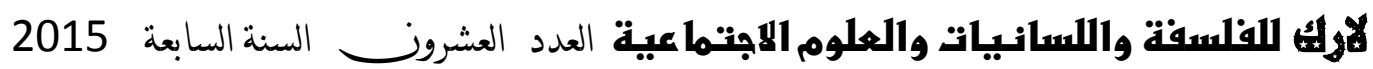
 